Editora Poisson

(organizadora)

\section{Série Educar - Volume 27 \\ Matemática}

1a Edição

Belo Horizonte

Poisson

2020 


\section{Editor Chefe: Dr. Darly Fernando Andrade}

\section{Conselho Editorial}

Dr. Antônio Artur de Souza - Universidade Federal de Minas Gerais

Ms. Davilson Eduardo Andrade

Dra. Elizângela de Jesus Oliveira - Universidade Federal do Amazonas

Msc. Fabiane dos Santos

Dr. José Eduardo Ferreira Lopes - Universidade Federal de Uberlândia

Dr. Otaviano Francisco Neves - Pontifícia Universidade Católica de Minas Gerais

Dr. Luiz Cláudio de Lima - Universidade FUMEC

Dr. Nelson Ferreira Filho - Faculdades Kennedy

Ms. Valdiney Alves de Oliveira - Universidade Federal de Uberlândia

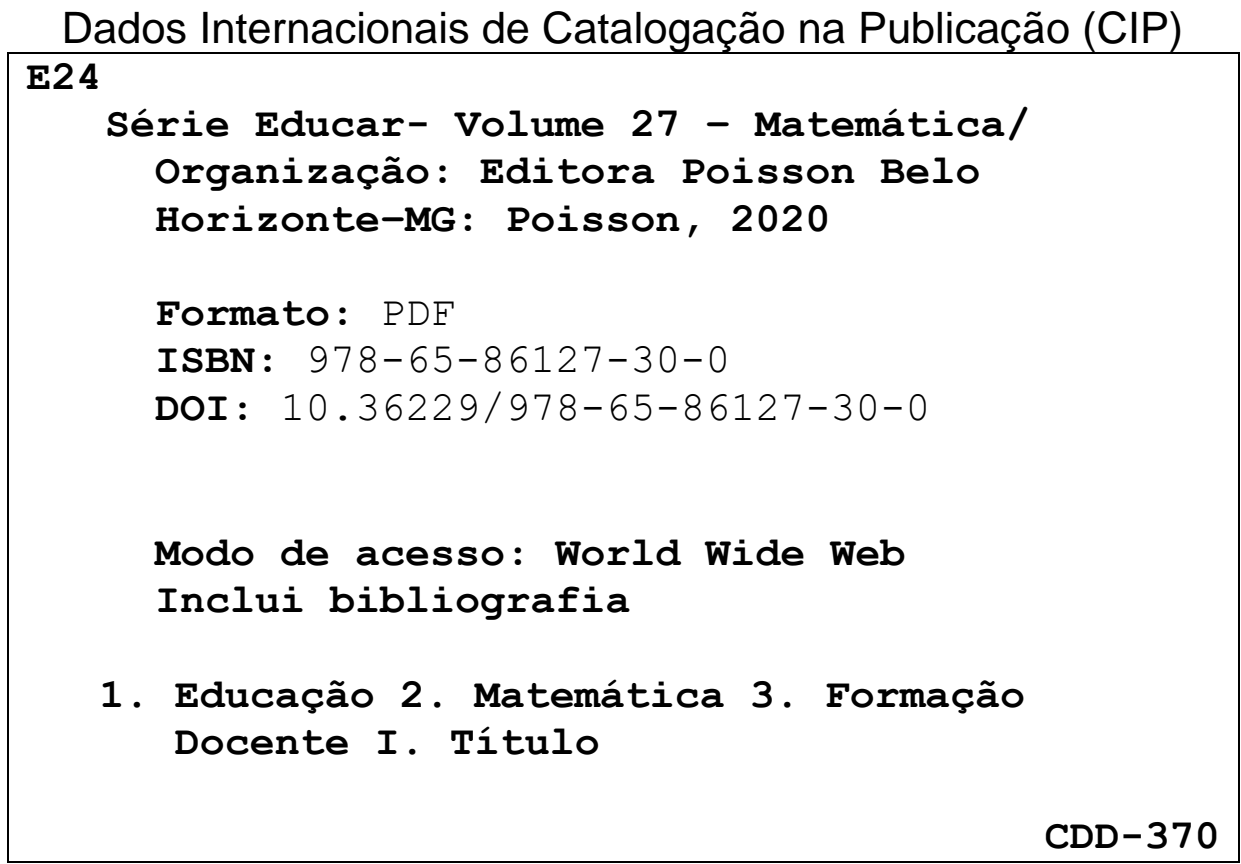

O conteúdo dos artigos e seus dados em sua forma, correção e confiabilidade são de responsabilidade exclusiva dos seus respectivos autores

$\underline{\text { www.poisson.com.br }}$

contato@poisson.com.br 


\section{SUMÁRIO}

Capítulo 1: 0 desenho e o pensamento infantil: Uma pesquisa com professores que ensinam Matemática 08

Ana Paula Bergo da Silva, Edilson dos Santos Araújo, Luciana Figueiredo Lacanallo Arrais

DOI: 10.36229/978-65-86127-30-0.CAP.01

Capítulo 2: 0 uso intencional dos blocos lógicos: Reflexões e possibilidades na Educação Infantil. 17

Wirla Castro de Souza Ramos, Salete Maria Chalub Bandeira

DOI: $10.36229 / 978-65-86127-30-0 . C A P .02$

Capítulo 3: Operando com números naturais nos anos iniciais do Ensino Fundamental: Um olhar sob as lentes da teoria das situações didáticas 24

Wirla Castro de Souza Ramos, Itamar Miranda da Silva

DOI: 10.36229/978-65-86127-30-0.CAP.03

Capítulo 4: 0 uso do material dourado manipulável e da tecnologia no ensino dos números decimais para alunos do 6음 ano. 30

Viviane Menezes de Souza Machado, Salete Maria Chalub Bandeira

DOI: 10.36229/978-65-86127-30-0.CAP.04

Capítulo 5: 0 uso de jogos com cartas no ensino da Matemática. 37

Adriano Araquem Baia Menezes, Kédna Syuianne Quintas Melo, Mario Tanaka Filho

DOI: 10.36229/978-65-86127-30-0.CAP.05

Capítulo 6: 0 que o quadrilátero contou para a circunferência no jardim? 44

Leonilson Calixto de Souza, Marcela Madanês Chavier

DOI: 10.36229/978-65-86127-30-0.CAP.06

Capítulo 7: Um relato de experiência dos redatores de Matemática do Documento Curricular - Ensino Fundamental do estado do Rio Grande do Norte 51

Luciana Vieira Andrade, José Damião Souza de Oliveira, Josenildo Gomes de Oliveira Souza

DOI: 10.36229/978-65-86127-30-0.CAP.07 


\section{SUMÁRIO}

Capítulo 8: Educação Matemática Realística: Uma abordagem de ensino que pode oportunizar a aprendizagem Matemática a todos os alunos 58

Marta Burda Schastai, Lidia Schactai Silvano

DOI: $10.36229 / 978-65-86127-30-0 . C A P .08$

Capítulo 9: A aprendizagem da Matemática: Uma possibilidade para todos 66

Carmen Lúcia Giuntini, Marlene Silva Rodrigues, Valéria de Cássia Gasques Mortari, Vanilda Carvalho Mendes

DOI: $10.36229 / 978-65-86127-30-0 . C A P .9$

Capítulo 10: A criação da régua de números inteiros adaptada para o Braille a partir da modificação do material dourado 76

Douglas Lopes do Nascimento, Lenilson Oliveira do Nascimento, Lauro Lopes Pereira Neto, Camila Lima da Costa

DOI: $10.36229 / 978-65-86127-30-0 . C A P .10$

Capítulo 11: Ensino e aprendizagem sobre Teoria dos Números: Debates e discussões 84

Edmilson Pereira, José Messildo Viana Nunes

DOI: $10.36229 / 978-65-86127-30-0 . C A P .11$

Capítulo 12: Explorando o conceito de medidas dentro de uma receita . .98

Ligiane Oliveira dos Santos Souza, Elizane Gomes do Espirito Santo Tanques, Lutecia Martins da Silva, Mariluce Aparecida de Lima, Aristimar Roberta de Oliveira, Fernanda Souza de Arruda

DOI: $10.36229 / 978-65-86127-30-0 . C A P .12$

Capítulo 13: 0 estudo da periodicidade de uma função trigonométrica a partir de um experimento envolvendo a roda gigante. 103

Sandra Regina D’ Antonio Verrengia, Vanessa Cristina Rhea, Jessica Suzana Barragan Alves

DOI: 10.36229/978-65-86127-30-0.CAP.13

Capítulo 14: Taxa de evasão dos cursos da URCA com as disciplinas de Matemática na grade curricular. 110

Ana Josicleide Maia, Aline Alves de Oliveira, Cibelle Teixeira de Oliveira, Ana Roberta Duarte Piancó DOI: 10.36229/978-65-86127-30-0.CAP.14 


\section{SUMÁRIO}

Capítulo 15: A utilização do aplicativo Geogebra para smartphone na construção de gráficos de situações-problemas envolvendo juros simples e compostos.. 115

Décio de Oliveira Gröhs, Michael Araújo de Oliveira, Gilberto Francisco Alves de Melo

DOI: $10.36229 / 978-65-86127-30-0 . C A P .15$

Capítulo 16: Software Geogebra e resoluções de problemas: Análise de uma experiência de ensino e aprendizagem 122

Gabriel Araújo Freitas, Roberto Barcelos Souza

DOI: 10.36229/978-65-86127-30-0.CAP.16

Capítulo 17: 0 logo no processo de aprendizagem em Matemática 1129

Gabriel Geraldino Cardoso, Elisangela Pavanelo

DOI: $10.36229 / 978-65-86127-30-0 . C A P .17$

Capítulo 18: (Des)aproximações entre teoria e prática na formação de professores de Matemática da UFMS CPTL 137

Gerson dos Santos Farias, Paulo Fioravante Giareta, Eugenia Brunilda Opazo Uribe

DOI: 10.36229/978-65-86127-30-0.CAP.18

Capítulo 19: A formação de professores de Matemática da rede estadual no processo de implementação do currículo do Estado de São Paulo (2008) 146

Eliane Maria Vani Ortega, Maria Raquel Miotto Morelatti, Leny Rodrigues Martins Teixeira, Monica Fürkotter, Luiz Fernando Carvalho, Maria Cecília Fonçatti, Érika Aparecida Navarro Rodrigues, Oscar Massaru Fujita, Raquel Gomes de Oliveira

DOI: $10.36229 / 978-65-86127-30-0 . C A P .19$

Capítulo 20: Os relatórios de estágios supervisionados de um curso de licenciatura em Matemática: Possibilidades de diálogos entre a avaliação e processos formativos..... 154 Januária Araújo Bertani

DOI: $10.36229 / 978-65-86127-30-0 . C A P .20$

Capítulo 21: 0 que dizem as narrativas sobre a identidade do professor que ensina Matemática no Ensino Fundamental? 161

Dayse do Prado Barros, Marcus Vinícius Pereira

DOI: $10.36229 / 978-65-86127-30-0 . C A P .21$ 


\section{SUMÁRIO}

Capítulo 22: Sentidos da formação continuada em Matemática: Contribuições do PNAIC em uma Escola Estadual de Araputanga/MT 170

Jorcélia Erminia da Silva Carneiro, Cláudia Landin Negreiros

DOI: 10.36229/978-65-86127-30-0.CAP.22

Capítulo 23: A trilha dos números: Explorando pistas e encontrando múltiplos 183

Moises da Silva Santos, Adriana de Souza Lira, Luria Thamires Brito da Costa, Sinval de Oliveira DOI: $10.36229 / 978-65-86127-30-0 . C A P .23$

Capítulo 24: A formação de educadores e as concepções sobre resolução de problemas no ensino de Matemática. 189

Jéssica Tomiko Araújo Mitsuuchi, Tania Teresinha Bruns Zimer

DOI: $10.36229 / 978-65-86127-30-0 . C A P .24$

Capítulo 25: Atividade investigativa: Resolvendo um problema envolvendo sistema de equações do 1ํㅡㅁau. 199

Flaviano Gomes Nascimento, Taiane Santana de Carvalho, Grace Dórea Santos Baqueiro

DOI: $10.36229 / 978-65-86127-30-0 . C A P .25$

Autores: 206 


\section{Capítulo 1}

\section{O desenho e o pensamento infantil: Uma pesquisa com professores que ensinam Matemática}

Ana Paula Bergo da Silva

Edilson dos Santos Araújo

Luciana Figueiredo Lacanallo Arrais

Resumo: 0 objetivo desse trabalho é apresentar a concepção de professoras dos anos iniciais do Ensino Fundamental sobre o papel do desenho, enquanto um recurso didático, no ensino de conceitos matemáticos. Originado de um Trabalho de Conclusão de Curso (TCC) em Pedagogia, utilizamos como instrumento de pesquisa um questionário aplicado para 9 professoras do $1^{\circ}, 2^{\circ}$ e $3^{\circ}$ ano de escolas públicas do Ensino Fundamental. Com os resultados obtidos, concluímos que os encaminhamentos didáticos se apresentaram confusos no que se refere ao uso do desenho na matemática, sendo entendido apenas como tabelas e gráficos, evidenciando a falta de clareza desse recurso vinculado na matemática. De acordo com os pressupostos da Teoria Histórico-Cultural, o desenho, enquanto uma linguagem, pode promover a aprendizagem, desde que seja conduzido de modo intencional e planejado e não como mero passatempo. Esperamos que a partir dessas considerações, possamos repensar e reavaliar a organização do ensino de matemática tendo o desenho como um recurso didático capaz de potencializar a aprendizagem quando percebido como linguagem, expressão e comunicação do pensamento, ideias e conceitos.

Palavras-chave: Desenho; Ensino da Matemática; Aprendizagem. 


\section{INTRODUÇÃO}

Os alunos de modo geral sabem matemática? Alguns alunos, concluem a educação básica sem terem, muitas vezes, a concepção do que é essa ciência e o que ela envolve. A matemática com suas características e especificidades próprias, precisa ser apresentada a eles como um conhecimento que retrata o movimento da sociedade. Um dos desafios na escola é desencadear nesses sujeitos a necessidade de aprender e compreender que quando falamos em matemática não estamos considerando apenas o número isolado e nem um conhecimento pronto e acabado (MOURA, 2010).

Durante o curso de Pedagogia nas disciplinas obrigatórias de estágios supervisionados e como participante do Programa Institucional de Bolsa de Iniciação à Docência (PIBID) com foco na educação matemática, presenciei momentos em que esse ensino ficava muito distante da compreensão deste movimento. Durante os trabalhos com os alunos nas escolas, enquanto acadêmica, questionava se gostavam de aprender matemática e, a fala de um dos alunos expressava, como a reconheciam: "Eu gosto de matemática, mas a gente só faz continhas daí eu não gosto" (L., 8 anos).

Tendo a preocupação de revertermos e/ou minimizarmos essa situação, com base nos pressupostos da Teoria Histórico-Cultural buscamos repensar o que ensinar; como ensinar e o porquê ensinar a fim de assegurarmos a apropriação dos conhecimentos científicos. Nessa direção, durante os encontros de formação do PIBID começamos a pensar em estratégias e recursos que pudessem contribuir com o processo educativo.

Dentre esses, um em especial, despertou nossa atenção: o desenho. Isso porque, é preciso buscar meios de gerar o interesse dos alunos para os conhecimentos em questão e, quando pensamos na Educação Infantil, esse recurso é muito presente, com potencial de aprendizagem e ensino reconhecido por alunos e professores. Na Educação Infantil, os alunos conversam sobre o desenho, representam por meio dele o que ouviram, vivenciaram ou imaginaram.

Todavia, quando ingressam no Ensino Fundamental essa relevância não é preservada e, certas vezes, desenhar torna-se uma ação é exaustiva e sem sentido. 0 desenho é solicitado geralmente, ao término de cada tarefa, nos últimos minutos antes do sinal quando não se pode iniciar um novo trabalho, ou ainda, somente para aqueles que terminam primeiro o que é solicitado pelo professor.

Para que o desenho seja um recurso didático que contribuía com a aprendizagem não pode ser conduzido somente das maneiras relatadas. É necessário que a forma de trabalho com ele esteja vinculada a princípios teóricos que o caracterizem de significados e seja utilizado como expressão do pensamento infantil nos anos iniciais do Ensino Fundamental, caso isso não aconteça, o desenho "[...] esvazia-os de sentido, induzindo a criança ao abandono dos mesmos. É incidindo sobre a área de desenvolvimento potencial que, de fato, atuam sobre o desenvolvimento infantil" (ARCE \& MARTINS, 2010, p. 76).

Assim, no intuito de compreendermos o papel do desenho nas aulas de matemática apresentamos essa Comunicação Científica, originado de um Trabalho de Conclusão de Curso (TCC) em Pedagogia. 0 objetivo desse relato é apresentar a concepção de professoras dos anos iniciais do Ensino Fundamental sobre o papel do desenho, enquanto um recurso didático, no ensino de conceitos matemáticos.

0 instrumento dessa investigação foi um questionário aplicado com 9 professoras do $1^{\circ}, 2^{\circ}$ e $3^{\circ}$ ano de escolas públicas do Ensino Fundamental parceiras do PIBID do foco matemática, no ano de 2016 nas turmas em que atuavam. Foram três professoras de cada uma das três escolas parcerias, sendo cada uma regente de uma das turmas dos anos iniciais do Ensino Fundamental.

Nesse texto, primeiramente, discutiremos a relação da matemática e o desenho entendendo-os como linguagens que, ao estarem inseridas em ações de ensino, são capazes de potencializar o processo educativo. Na sequência, apresentamos a análise dos dados, uma possibilidade de encaminhamento teórico-prático com a temática anunciada, pois como resultado de nossa pesquisa, o desenho não é inserido como um recurso nas aulas de matemática e por fim, as considerações finais.

Esperamos que com os resultados da pesquisa possamos colaborar com o trabalho de ensino, tendo o desenho, como um recurso mais vinculado a compreensão de conceitos matemáticos. Ampliar as possibilidades de encaminhamentos teórico-práticos pode ser uma forma de promover mais qualidade ao processo educativo. 


\section{O DESENHO E A MATEMÁTICA: UMA RELAÇÃO POSSÍVEL}

Pesquisas realizadas em âmbito nacional (PROVA BRASIL, 2014, ANA, 2014) e internacional (PISA, 2009) veem apresentando resultados preocupantes em relação ao ensino de matemática na educação. Isso porque, o desempenho escolar avaliado está abaixo do esperado para o ano escolar e a idade dos alunos, o que coloca o Brasil, por exemplo, segundo dados do PISA (2009), na posição 57ạ no desempenho na matemática dentre os 65 países avaliados.

Sabemos que os resultados dessas avaliações não explicam isoladamente o desempenho escolar preocupante na matemática, pois esse ensino tem problemas que são históricos e que fazem essa ciência ser concebida como algo a parte, isolada da vida dos educandos e de outras ciências (CARAÇA, 1989). Em sala de aula, a matemática apresenta-se, na maioria das vezes, de modo mecânico com ênfase nos numerais e operações aritméticas, desconsiderando o percurso histórico e social feito para a produção dos seus conceitos.

Caraça (1951) aponta a importância de se pensar em ações docentes ao ensinar matemática mais transformadoras, já que a ciência, não é aquela só dos livros didáticos e sim aquela que provoca hesitações, dúvidas e contradições. De acordo com o autor essas provocações relacionam a ciência com a sociedade, pois "[...] vê-se toda a influência que o ambiente da vida social exerce sobre a criação da ciência" (CARAÇA, 1951, p. XIII).

Ao apresentarmos aos alunos a matemática vinculada à vida, a concepção não será de uma ciência fechada e consolidada, mas vão reconhecê-la, em todos os contextos sociais. Assim, ao dividir uma bolacha, inserir alguém na brincadeira, organizar espaços para jogos, explicar onde mora, o aluno perceberá a necessidade da matemática, mas como um conhecimento produzido historicamente por homens e sistematizado como produto científico.

Como educadores, faz-se necessário pesquisarmos princípios e encaminhamentos que possam assegurar essa aprendizagem. 0 ensino da matemática precisa ser organizado e, isso exige um trabalho diferenciado por parte do professor, tanto na elaboração de tarefas como no constante movimento de estudo e pesquisa em torno dos conceitos. As ações de ensino e de aprendizagem precisam integrar professor e aluno de modo coerente e contínuo (MOURA, 2007).

Embasados nos estudos da Teoria Histórico-Cultural (LORENZATO, 2008; LURIA, 2008; MOURA, 1996; VYGOTSKY, 1995) entendemos que as atividades de ensino precisam ser pensadas a partir de situações desencadeadoras de aprendizagem, que despertem na criança a necessidade de solução aproximando-a da essência do conceito. 0 ensino planejado e intencional precisa potencializar a aprendizagem enquanto uma necessidade para professor e aluno.

Dentre as possibilidades de ensino, apresentamos o desenho como uma linguagem que desenvolve o raciocínio, análise, síntese, ou melhor, a organização do pensamento. Precisamos compreender que a linguagem permite que a criança perceba, explore e aproprie-se do conhecimento sobre o mundo, o que determina o seu desenvolvimento mental. Luria (2008, p. 24) destaca essa aquisição para o homem, já que,

A linguagem, que medeia a percepção humana, resulta em operações extremamente complexas: a análise e síntese da informação recebida, a ordenação perceptual do mundo e o enquadramento das impressões em sistemas. Assim as palavras - unidades linguísticas básicas - carregam, além de seu significado, também as unidades fundamentais da consciência que refletem o mundo exterior.

A linguagem está diretamente vinculada ao pensamento, pois por meio dela "intelectualiza-se, une-se ao pensamento e o pensamento verbaliza-se " (VYGOTSKY, 1995, p. 172). Podendo expressar a linguagem de diferentes maneiras: movimentos, gestos, verbalmente pela palavra, escrita, desenho dentre outras maneiras que representam o pensamento. Ressaltamos o desenho,

Quando a criança desenha, desenha o que sabe sobre o objeto e não o que vê. Por isso ela frequentemente desenha coisas que não vê e, por outro lado, deixa de fora muito do que indubitavelmente vê porque, para ela, não é o elemento essencial para o objeto considerado (VIGOTSKI, 2014, p. 98).

Quando as crianças reconhecem sentido e significado em seus registros, podem perceber que sua produção demonstra funções mentais características do homem capazes de contar histórias, explicar ideias e conceitos, de acordo com Lorenzato (2008). 0 autor afirma que o desenho, auxilia a criança a reconhecer as coincidências entre o que está pensando e o que isso significa para ela, sem muitas vezes ser 
necessário registrar números, símbolos ou tentar escrevê-los. 0 desenho se apresenta como veículo do pensamento e o intermediário entre o abstrato e o concreto, externalizando o próprio raciocínio.

Em razão disso, "[...] contar, realizar cálculos, registrá-los, poderá tornar-se para ela(s) uma necessidade real" (MOURA, 1996, p. 20). Ao perceber que seus registros auxiliam a expressar o pensamento, ele passa a ser concebido como instrumento da ação. Comungamos da metodologia que Moretti e Souza (2015, p. 48) relata aos professores "propor às crianças situações nas quais elas tenham de juntar quantidades e posteriormente comunicá-las, o que lhes colocará a necessidade do registro" é uma estratégia que pode assegurar significado aquilo que se ensina.

Desse modo, a matemática e o desenho entendidos como linguagens que, estão inseridos em ações de ensino e são capazes de potencializar o processo de aprendizagem, é concebido como um produto histórico, pois o registro da criança se assemelha ao mesmo modo que os antigos povos realizavam seus feitos. Ifrah (1998) exemplifica a importância do uso do desenho quando historicamente foi adotado para representação das quantidades de modo abstrato no comércio de ovelhas dos mesopotâmicos e elamitas. Os registros, em forma de desenhos, utilizados pelos comerciantes configuravam-se como instrumento mnemônico.

[...] eram, portanto, signos, pois tinham como pressuposto a representação de algo concreto, mas já desencarnados do mesmo. Eram a lembrança sintetizada em uma representação que tem uma história, síntese de várias outras que foram construídas a partir de uma necessidade humana universal, que é a de se comunicar para solucionar problemas colocados pela vida em sociedade (MOURA, 2013, p. 115).

Isso evidencia que, é possível relacionar o desenho nas aulas de matemática e promover a aprendizagem dos alunos. Mas, como esse recurso é percebido pelos professores nas aulas de matemática? Em busca dessa resposta, a investigação foi direcionada.

\subsection{A PESQUISA, OS RESULTADOS E AS POSSIBILIDADES}

Aplicamos um questionário a professoras que atuavam nos anos iniciais do Ensino Fundamental com questões semiabertas, a fim de verificar os limites e possibilidades do uso do desenho nas aulas de matemática. 0 uso do questionário para a coleta de dados, denominado por Gil $(2008$, p. 114) como "um conjunto de questões que são respondidas por escrito pelo pesquisado". Optamos pelo uso desse instrumento, pois possibilitou o anonimato do autor as respostas, a liberdade para as respostas e ao mesmo tempo viabiliza "[...] traduzir os objetivos específicos da pesquisa em itens bens redigidos" (GIL, 2008, p. 116).

Participaram da pesquisa 9 professoras de três escolas municipais do noroeste do Paraná, organizados em 3 grupos de acordo com a turma em que atuaram no ano de 2016. Essas professoras trabalhavam nas 3 escolas em que o PIBID- Pedagogia realizava parceria e isso viabilizou a pesquisa. 0 perfil de identificação mostra que todas possuíam graduação em Pedagogia e $75 \%$ delas já exerciam a profissão docente por mais de 10 anos.

Questionamos primeiramente como o desenho era utilizado em sua prática pedagógica. No Gráfico 1, percebemos que as respostas indicaram que apenas no $1^{\circ}$ ano, o desenho é entendido e utilizado como registro. Nos $2^{\circ}$ e $3^{\circ}$ anos, o desenho é apontado apenas para ilustração e fixação dos conteúdos, como podem perceber nas respostas de algumas professoras.

P. 1a ano $A^{1}$ : Por meio do registro, pois o desenho contribui para desenvolver a criatividade e para melhorar a qualidade do ensino aprendizagem.

P. 3a ano B: Além de ilustração, utilizo também para fixação dos conteúdos.

\footnotetext{
1 Utilizamos a abreviatura $P$ seguida de um número para identificar o ano de atuação da professora participante da pesquisa e a letra indicando se é da Escola A, B ou C.
} 
Gráfico 1 - 0 desenho na prática pedagógica

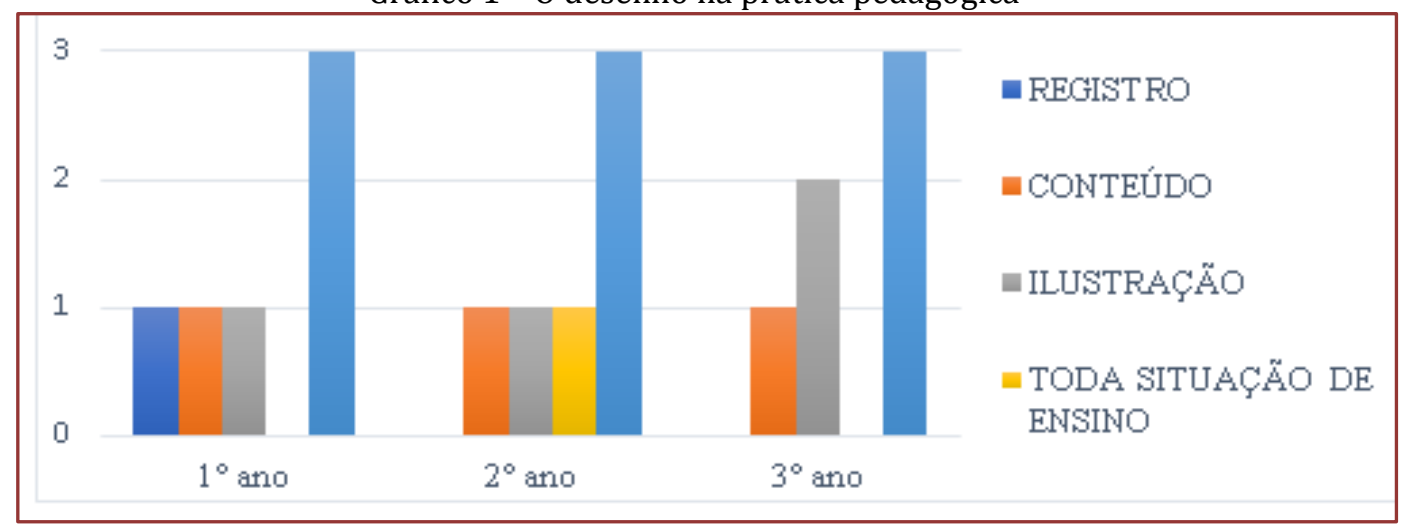

Fonte: elaborado pelos autores

Percebemos que a função do desenho do primeiro ao terceiro ano, se altera quando pensamos em sua intencionalidade pedagógica. Na concepção das professoras que participaram, o aluno pode expressar seu pensamento, por meio do desenho, mas com a considerável complexidade dos conteúdos, o desenho começa a ser reduzido para a ilustração de ideias e conteúdo, para aqueles que terminam mais rápidos as atividades propostas, mas não como expressão do pensamento ou raciocínio. Salientamos que ilustrar nem sempre representa a apropriação de conceitos.

Nos primeiros anos do Ensino Fundamental, um dos interesses da criança está no desenhar (VIGOTSKI, 2014). Ao ingressar na escola, se o professor vincular esse interesse com o aprendizado poderá possibilitar mais significado e sentido a ação, para que não se esvazie e perca sua função. Vygotsky (1995, p. 65) alerta que "a medida que a criança cresce e entra na infância, ela muitas vezes se sente desapontada e apática sobre o desenho".

Na segunda questão perguntamos se o desenho era empregado nas tarefas matemáticas e como isso era feito. Todas afirmaram empregar o desenho, mas conforme verificamos no Gráfico 1, ao especificarem o como, a confusão e diversidade nos encaminhamentos didáticos pode ser percebida.

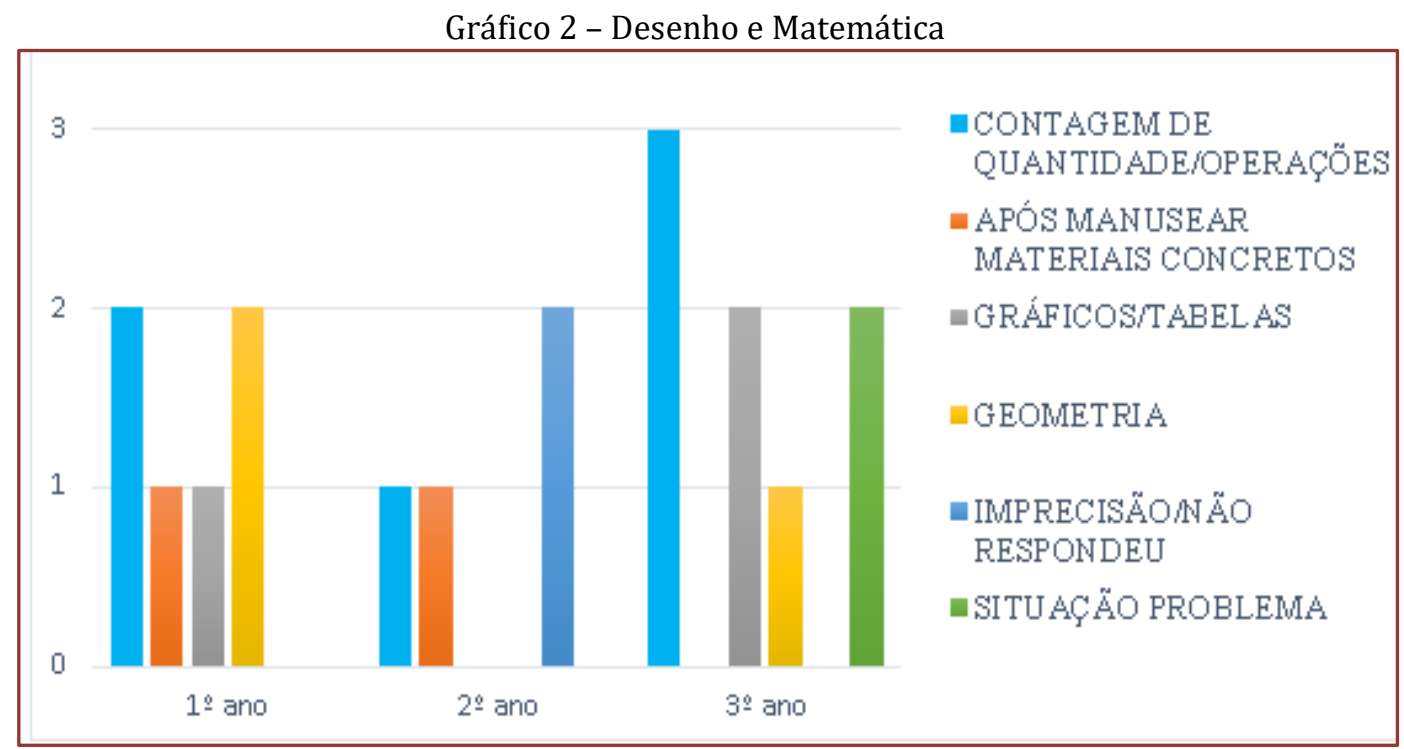

Fonte: elaborado pelos autores

As professoras mostraram incertezas sobre esse uso, fazendo em muitas das respostas uma apresentação de conteúdos matemáticos, ou seja, apontaram os conteúdos e não como empregam o recurso, como podemos constatar na resposta abaixo. 
P. 2o ano C: Sim, primeira coleta dos alunos, eles procuram primeiro mostrar sua experiência no desenho, chegando ao conceito e a aprendizagem através de suas criações. O desenho e a prática são fundamentais para mim (material concreto).

Destacamos que, um terço das professoras investigadas, afirmam empregar o desenho para construir tabela e gráfico, no entanto essa é uma forma distorcida de uso do desenho nas aulas de matemática, já que esses são conteúdos matemáticos.

Ainda que de forma não tão expressiva numericamente, algumas professoras conseguiram externalizar o momento e o como trabalham com o desenho nas aulas de matemática, principalmente no primeiro ano.

P. 1a ano B: Sim, o primeiro momento com material concreto, após o manuseio registro no caderno por meio do desenho, no qual ajuda a efetivar a compreensão da aprendizagem do ensino matemático.

Nas professoras de segundo ano, evidenciamos pelas falas a preocupação em direcionar e enriquecer o desenho aliando-o ao uso do material concreto para efetivar o registro do raciocínio do aluno pelo desenho, como podemos observar na fala da professora abaixo.

P. $2^{o}$ ano C: Sim, para representar/ilustrar quantidades e resultados obtidos nas situações problemas/operações, bem como na representação do material dourado, ábaco, figuras geométricas, entre outras.

Na sequência da pesquisa questionamos as professoras sobre a frequência com que usavam o desenho na matemática, tendo como alternativas: Raramente; Às vezes; Depende do conteúdo ou Outros momentos. Cerca de $90 \%$ das professoras responderam que a utilização do desenho depende do conteúdo, 5\% apresentou resposta imprecisa e outros 5\% não responderam. Para exemplificar a maioria das respostas das professoras, apresentamos a fala de um dos sujeitos.

P $3^{o}$ ano A: Depende do conteúdo que está sendo estudado, exemplo, medida de capacidade, sistema monetário, desenho do material concreto para representação de números, entre outros.

Concordamos com Moura et al (2016, p. 158) que "[...] o caráter concreto de que se reveste uma abstração necessária forma-se na prática humana coletiva” e esta configuração se modifica no trabalho humano como concreto. As abstrações individuais, também, se combinam numa razão coletiva, reproduzindo ou refazendo o concreto, configurando assim "como concreto pensado pelo ser humano para o homem, como concreto para si (para o homem)” (MOURA et al, 2016, p. 159).

Percebemos pelas respostas das professoras participantes que todas reconhecem o desenho e sua importância no ensino, mas quando especificamos a matemática, em outras questões, não evidenciamos clareza sobre como isso acontece.

P 1o ano C: Ajuda para melhor entender as atividades fazendo representações através dos desenhos.

Nas respostas das professoras que atuam no segundo e terceiro ano o desenho é visto como facilitador do aprendizado do aluno na matemática, no entanto, faltam argumentos para explicar como utilizam e como esse é explorado.

P 3a ano A: Sim, é de extrema importância para a compreensão do estudo, sobretudo na área da matemática. Podemos evidenciar o declínio do uso do desenho ao longo do Ensino Fundamental. Enquanto, no $1^{\text {o ano }}$ escolar, o desenho é entendido como componente das aulas de matemática, no $3^{\circ}$ ano, seu uso perde muito da intencionalidade pedagógica e passa a ser meramente ilustrativo e não tanto expressão do pensamento. Lorenzato (2008, p. 41) ressalta que a utilização deste recurso nas aulas de matemática, precisa da correta intervenção do professor, ou seja,

É importante que, após a verificação de cada proposta, o professor peça às crianças que expliquem o que foi feito, o que aconteceu, em seguida, essa situação precisa ser registrada, o que pode ser feito com o auxílio de desenhos.

Assim, ainda que o professor reconheça a importância do desenho e o conceba como aliado do ensino, desconhece formas de conduzi-lo nas aulas de matemática, sendo que poucas professoras conseguiram apresentar encaminhamentos didáticos bem direcionados de trabalho com o desenho.

Precisamos nas aulas de matemática, realizar o desenho, pensar sobre ele, falar e analisá-lo, pois, essas estratégias podem auxiliar na formação do pensamento concreto, abstrato e na aprendizagem de conceitos científicos assegurando compreensão ao aluno e ao professor. Compreendemos que o desenho pode ser definido como "uma linguagem gráfica que surge tendo por base a linguagem oral, sendo que as crianças não desenham o que veem, mas sim o que conhecem" (ARCE \& MARTINS, 2010, p. 134), sendo um aliado no desenvolvimento do pensamento e de outras funções mentais da criança. 
Desse modo, uma das possibilidades de trabalho com ele pode ser associando-o ao lúdico, mas sem perder de vista a finalidade da promoção da aprendizagem do conceito científico (MOURA, 1992). Assim, podemos empregá-lo para registrar o final de um jogo, isso porque para realizar esse registro o aluno não recorre "[...] apenas a observação direta, mas a análise do desenho revelou que a criança desenha de memória" (VIGOSTKI, 2014, p. 97). O desenho nesse contexto, caracteriza-se como um raio-X, que de acordo com o autor, permite ao professor observar, o pensamento e a linguagem matemática e como essas foram compreendidas pelos alunos.

Na Figura 2 explicamos o desenho feito por uma aluna de $2^{\circ}$ ano após o jogo de Pega-Varetas. Após jogar, ela registrou a posição de varetas em um dos momentos difíceis do jogo, em que deveria pensar na cor que possuía o valor maior ou na vareta mais fácil de ser retirada. Ao observarmos a Figura 2, podemos verificar que por meio de desenhos foi possível identificar "como estratégia pessoal de solução" (MORETTI; SOUZA, 2015, p. 85).

Figura 2: Registro da pontuação

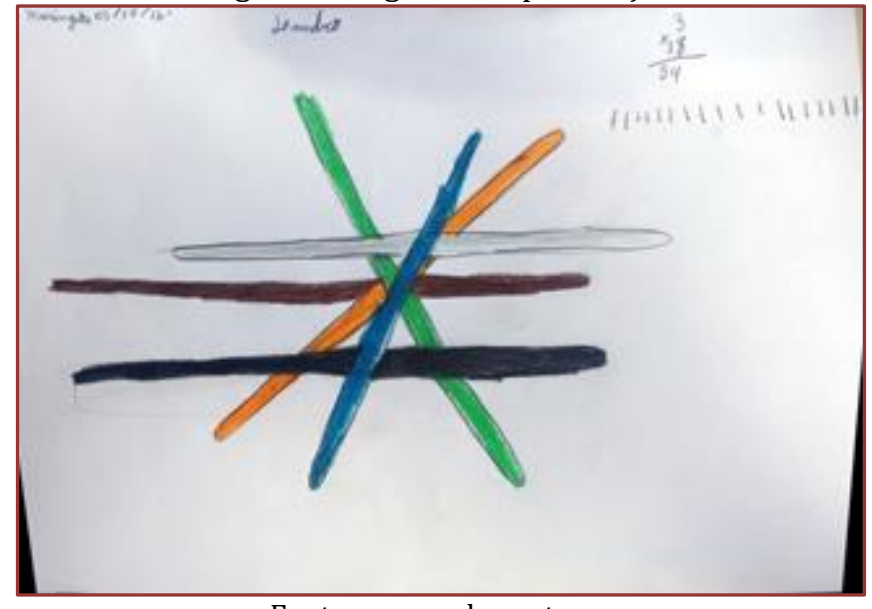

Fonte: acervo dos autores

O aluno com o apoio do desenho, conseguiu reconhecer suas estratégias e também calcular os pontos com as varetas capturadas recorrendo a multiplicação, percebe-se também na parte superior do lado direito que ele recorreu a confirmação dos pontos através do cálculo. Luria (1977, p. 124) revela que "[...] a linguagem não é apenas um meio de generalização; é, ao mesmo tempo, a base do pensamento". Como observamos na Figura 2, o aluno utilizou o desenho representativo das varetas, os algarismos para o cálculo e os "risquinhos" para auxiliar no cálculo. 0 desenho mostra como para solucionar um problema, a criança põe em movimento, as muitas formas de raciocínio que, com outro recurso poderia não ser evidenciado.

Aliar o desenho a aprendizagem matemática, concordamos com Moura (2001, p. 54) "é dar significado ao que aprender; não só para o indivíduo, mas também para toda a instituição escolar. Dar sentido à aprendizagem da matemática também está dando significado à educação"2. Luria (1987) ressalta que o desenho

[...] a fase pictográfica do desenvolvimento da escrita é alimentado com a rica experiência de desenho da criança que, por si só, não pode servir como um mediador assinar qualquer processo intelectual. No início, o desenho é desenvolvido como um jogo, como um processo independente de representação e só depois deste ato pronto pode ser utilizado como procedimento como um meio, tal como meio de registo ${ }^{3}$ (p. 53).

\footnotetext{
2 No texto espanhol lê-se: "Se trata de dar significado al qué aprender; no sólo para el sujeto, sino también para toda la institución escolar. Dar significado al aprendizaje de la matemática es dar sentido también a la educación" (MOURA, 2011, p. 54).

3 No texto em espanhol lê-se: "La fase pictográfica en el desarrollo de la escritura se alimenta con la riquisima experiencia del dibujo infantil que, por si mismo, puede no servir de signo mediatizador en un proceso intelectual cualquiera. Al comienzo el dibujo se desarrolla como juego, como proceso independiente de representación y sólo después este acto ya listo puede ser utilizado como procedimento, como medio, como via para el registro" (LURIA, 1987, p.53).
} 
Podemos constatar a partir deste registro e apontamentos que o desenho pode ser considerado como apoio a memória, a linguagem matemática, ao pensamento, aos cálculos e estratégias empregadas.

Nessa direção, podem ser possibilidades de encaminhamentos teórico-práticos, o professor oportunizar situações em que as crianças sintam a necessidade do registro para explicar suas ideias ou mesmo testalas. É necessário problematizar os desenhos, fazendo relação com as especificidades e regularidades da matemática, assegurando significado entre aquilo que se ensina e aquilo que se compreende, estimulando diferentes formas de registro e de possibilidades de resoluções.

\section{CONSIDERAÇÕES FINAIS}

O objetivo desse trabalho foi apresentar a concepção de professoras dos anos iniciais do Ensino Fundamental sobre o papel do desenho, enquanto um recurso didático, no ensino de conceitos matemáticos. Nessa investigação as respostas dos sujeitos mostraram o desenho associado a contagem e as operações aritméticas, como um recurso isolado e não inserido no processo de ensino. Não se reconheceu o desenho e nem a matemática como uma linguagem e como expressão e base do pensamento infantil.

Evidenciamos a dificuldade do professor em empregar o desenho nas aulas de matemática, mesmo o reconhecendo com importante recurso didático. Nas práticas didáticas descritas, não se percebeu significado e sentido ao desenho, parece ser algo solto e desvinculado da compreensão dos conceitos.

O desenho, assim como todo recurso didático, precisa estar vinculado a outras ações de estudo da criança, estando além de mero passatempo ou premiação aos alunos mais rápidos na execução das tarefas solicitadas pelo professor. Precisa-se criar a necessidade de o aluno agrupar, rever, ver quantos faltam para completar, organizar e expressar seu pensamento falando e pensando sobre o desenho feito.

Esperamos que a partir dessas considerações, possamos repensar e reavaliar a organização do ensino de matemática tendo o desenho como recurso didático que pode potencializar a aprendizagem quando percebido como linguagem, expressão e comunicação do pensamento, ideias e conceitos.

\section{REFERÊNCIAS}

[1] Arce, A.; Martins, L. M. Quem tem medo de ensinar na Educação Infantil? Em defesa do ato de ensinar. Alínea, Campinas, São Paulo, 2010.

[2] Brasil. INEP. Avaliação Nacional de Alfabetização - ANA. Disponível em: <http://www.inep.gov.br> Acesso em: 15 nov. 2016.

[3] Brasil. INEP. Programa Internacional de Avaliação de Estudantes - PISA. Disponível em: <http://www.inep.gov.br> Acesso em: 15 nov. 2016.

[4] Brasil. INEP. PROVA BRASIL. Disponível em: <http://www.download.inep.gov.br> Acesso em 15 nov. 2016

[5] Caraça, B. J. Conceitos fundamentais da matemática. Lisboa: Sá da Costa Editora, 1951.

[6] _ _ Conceitos fundamentais de matemática. 9. Ed. Lisboa: Livraria Sá da Costa, 1989.

[7] Gil, A. C. Como elaborar projetos de pesquisa. São Paulo: Atlas, 4 ed. 2008.

[8] IFRAH, G. Os números: a história de uma grande invenção. São Paulo: Editora Globo, 9ạ. edição, 1998.

[9] Lorenzato, S. Educação Infantil e percepção matemática. 2. ed. rev. Campinas: Autores Associados, 2008.

[10] Luria, A. R. O Papel da Linguagem na Formação de Conexões Temporais e a Regulação do Comportamento em Crianças Normais e Oligofrênicas. In: Luria, A. R.; Leontiev, A. N.; Vigotsky, L. S. et al. Psicologia e Pedagogia II: investigações experimentais sobre problemas didáticos específicos. Lisboa: Editorial Estampa, 1977.

[11] ___ La psicologia evolutiva y pedagógica en la URSS, Editora Progresso, 1987.

[12] _ _ _ Desenvolvimento cognitivo: seus fundamentos culturais e sociais. São Paulo: Ícone, 2008.

[13] Moretti, V. D.; Souza, N. M. M. Educação Matemática nos anos iniciais do Ensino Fundamental: princípios e práticas pedagógicas. 1a. ed. São Paulo: Cortez, 2015.

[14] Moura, A. R. L. et al. O concreto pensado. In: Educar com a Matemática: Fundamentos. 1. ed. São Paulo: Cortez, 2016, p.157165.

[15] Moura, M. O. A atividade de ensino como unidade formadora. Bolema. Ano II, n. 12. 1996, p. 29-43.

[16] _- Construção do signo numérico em situação de ensino. 1992. 151 f. Tese (Doutorado em Educação) - Faculdade de Educação, Universidade de São Paulo, São Paulo, 1992.

[17] __ A atividade de ensino como ação formadora. In: Castro, Amélia Domingues e CARVALHO, Anna Maria Pessoa de (Org.) Ensinar a ensinar: Didática para a Escola Fundamental e Média. São Paulo: Pioneira Thomson Learning, 2001. Cap. 8, p. 143-162. 
[18] __ Matemática na Infância. In: Migueis, M. e Azevedo, M. G. (Orgs). Educação Matemática na Infância. Vila Nova de Gaia/Portugal: Gailivivros.2007, p. 40-63.

[19] __ et al. Atividade Orientadora de Ensino: unidade entre ensino e aprendizagem. Revista Diálogo Educacional, Curitiba, v. 10, n. 29, Jan./abr. 2010, p. 205-229.

[20] __ A dimensão da alfabetização na educação matemática infantil. In: Kishimoto, T. M. \& FORMOSINHO, J. O. (Orgs). Em busca da Pedagogia da infância. Porto Alegre: Penso, 2013, p.110- 216.

[21] Vigotski, L. S. Obras Escogidas. Vol. III. Madrid: Visor, 1995.

[22] __ Imaginação e criatividade na infância. Martins Fontes, São Paulo, 2014. 


\section{Capítulo 2}

\section{O uso intencional dos blocos lógicos: Reflexões $e$ possibilidades na Educação Infantil}

\section{Wirla Castro de Souza Ramos \\ Salete Maria Chalub Bandeira}

Resumo: Este artigo configura-se como uma sistematização de estudos realizados durante a disciplina "Tecnologias e Materiais Curriculares para o Ensino da Matemática", desenvolvida no curso de Mestrado Profissional em Ensino de Ciência e Matemática da Universidade Federal do Acre. Tem como objetivo proporcionar reflexões sobre a importância do uso intencional dos Blocos Lógicos na Educação Infantil, tendo em vista a construção do conceito de número. Para tanto, buscou-se um aporte teórico baseado na teoria piagetiana e em autores que trazem questões pertinentes ao uso desse material manipulável, como por exemplo, Toledo e Toledo (1997). Produziu-se um vídeo demonstrativo sobre os processos mentais básicos relacionados ao processo de construção do conceito de número pela criança. Portanto, viu-se o quanto é importante aliar a educação a tecnologia, principalmente quando se vislumbra a formação continuada de professores e processos de aprendizagens mais significativos para os alunos.

Palavras-chave: Raciocínio lógico-matemático; Blocos lógicos; Tecnologia; Formação de professores. 


\section{INTRODUÇÃO}

Tendo em vista os estudos e as pesquisas na área da Educação Matemática, tem-se evidenciado as preocupações referentes ao ensino e a aprendizagem de Matemática nos mais variados níveis de escolaridade e em distintas dimensões, sejam teóricas e/ou práticas.

Este estudo refere-se a Matemática Escolar, numa perspectiva do desenvolvimento do raciocínio lógicomatemático pertinente a construção do conceito de número pelas crianças da Educação Infantil, tendo como foco o trabalho desenvolvido por professores que ensinam Matemática nesse nível e escolaridade.

Vale dizer que neste trabalho, enfatiza-se o uso do material manipulável chamado de Blocos Lógicos numa perspectiva de um trabalho pedagógico intencional, que visa proporcionar situações em que as crianças tenham diante delas possibilidades de desenvolverem o seu raciocínio lógico-matemático, indo em direção às futuras abstrações.

As práticas escolares, pautadas na memorização e na desconsideração dos conhecimentos já construídos pelas crianças, já se mostram inadequadas. Segundo Nunes (1997a), o começo da compreensão de conceitos matemáticos pela criança é precoce. As crianças pequenas, quando ingressam na escola têm alguma compreensão de conceitos matemáticos antes que sejam ensinadas formalmente sobre eles. Esta compreensão é frequentemente fragmentária e limitada e pode levar a criança a erros em algumas situações. Entretanto, é genuína no sentido de que em cada caso a criança entende algo sobre algumas relações envolvidas nos conceitos matemáticos e podem aplicar esta compreensão logicamente.

Desenvolver um trabalho pedagógico com a Matemática Escolar na Educação Infantil, prevê considerar reflexões sobre as teorias da aprendizagem. Dentre tais teorias, o destaque será dado à teoria construtivista piagetiana, uma vez que contempla importantes reflexões acerca do desenvolvimento cognitivo da criança nesta área do saber.

$\mathrm{Na}$ Educação Infantil, o desenvolvimento do raciocínio lógico-matemático precisa ser trabalhado intencionalmente tendo em vista a faixa etária das crianças. No trabalho com materiais didáticos manipuláveis, é muito importante a considerar estágio de desenvolvimento cognitivo das mesmas. Smole (2000a, p.63), diz que "o trabalho com a matemática na escola infantil não pode ser esporádico, espontaneísta e casual”.

Destaca-se neste texto, as possibilidades de aprendizagens que os Blocos Lógicos podem fazer emergir diante de um trabalho pedagógico pautado na construção de conhecimentos por parte das crianças, principalmente no que diz respeito ao desenvolvimento do raciocínio lógico - matemático pertinente a construção do conceito de número.

\section{FUNDAMENTAÇÃO TEÓRICA}

\subsection{REFLEXÕES SOBRE APRENDIZAGEM ESCOLAR E CONHECIMENTO LÓGICO-MATEMÁTICO NUMA ABORDAGEM COGNITIVISTA}

O homem é um ser eminentemente social e que aprende e se desenvolve a partir das interações sociais que vivencia. Entretanto, a construção de conhecimentos é algo que acontece interna e gradativamente na dinâmica cognitiva de cada pessoa. Sendo assim, parece sensato pensar numa prática pedagógica intencional, onde se propõe a valorização dos conhecimentos já construídos pela criança para o desenvolvimento do raciocínio lógico - matemático.

Vale frisar que, a valorização de tais conhecimentos parece mesmo pertinente, uma vez que se fala aqui de crianças ainda em seus primeiros anos de escolaridade da Educação Básica, considerando que ainda não vivenciaram situações de sistematização de saberes. No entanto, em suas relações com seus pares, construíram conhecimentos matemáticos não formalizados que precisam ser considerados diante do saber escolar.

É bastante difícil dizer exatamente quando as crianças começam a aprender matemática. Em um sentido formal, evidentemente, sua carreira matemática usualmente começa na escola, mas seria absurdo dizer que estas são as primeiras experiências matemáticas que as crianças têm ou o que elas não entendem sobre a matemática até serem ensinadas por um professor." (NUNES, 1997b, p, 35). 
Além disso, o professor se destaca como medidor do processo de construção de conhecimentos pelo aluno. É ele quem precisa planejar situações-problema, considerando a saber matemático em questão, que proporcionem a construção de novos conhecimentos. Assim, a escola, no papel do professor, como diz Smole (2000b, p.62), "deve fazer o aluno ir além do que parece saber, deve tentar compreender como ele pensa e fazer as interferências no sentido de levar cada aluno a ampliar progressivamente suas noções matemáticas".

É importante ressaltar que considerar o estágio de desenvolvimento cognitivo da criança quando se pretende proporcionar a construção de conhecimentos escolares é de suma importância, pois segundo a teoria construtivista de Piaget (1971), as atividades apresentadas precisam levar em consideração a faixa etária das crianças para que possam agir sobre elas de maneira significativa.

Vale frisar que aqui a intenção é proporcionar reflexões sobre as possibilidades de se trabalhar noções matemáticas junto as crianças bem pequenas, ainda no início da escolarização, ou seja, na Educação Infantil. Tais crianças estão incluídas na previsão de idade relacionada no estágio de desenvolvimento cognitivo $^{4}$ descrito, na teoria piagetiana, como pré-operatório.

Logo, práticas pedagógicas que insistem em enfatizar que as crianças precisam recitar sequências numéricas diariamente para que assim possam aprender a lógica que existe no sistema de numeração, são carregadas de equívocos, diante do que preconiza a teoria construtivista de Piaget (1971).

\subsection{USO INTENCIONAL DOS BLOCOS LÓGICOS}

Os Blocos Lógicos ${ }^{5}$ constituem-se como um material didático bastante usado e divulgado na década de 50 pelo matemático húngaro Zoltan Paul Dienes. Este material, confeccionado originalmente em madeira, é composto por quarenta e oito peças diferentes entre si. Tais peças possuem quatro atributos diferentes: cor (amarela, azul e vermelha) - 3 cores, tamanho (pequeno e grande) - 2 tamanhos, forma (tem-se objetos com face triangular, retangular, quadrangular e de base circular) - 4 formas e espessura (fina e grossa) - 2 espessuras, num total de $3 \times 2 \times 4 \times 2=48$ peças, conforme organizadas na Figura 1 .

Figura 1- Material Didático Manipulável Blocos Lógicos.

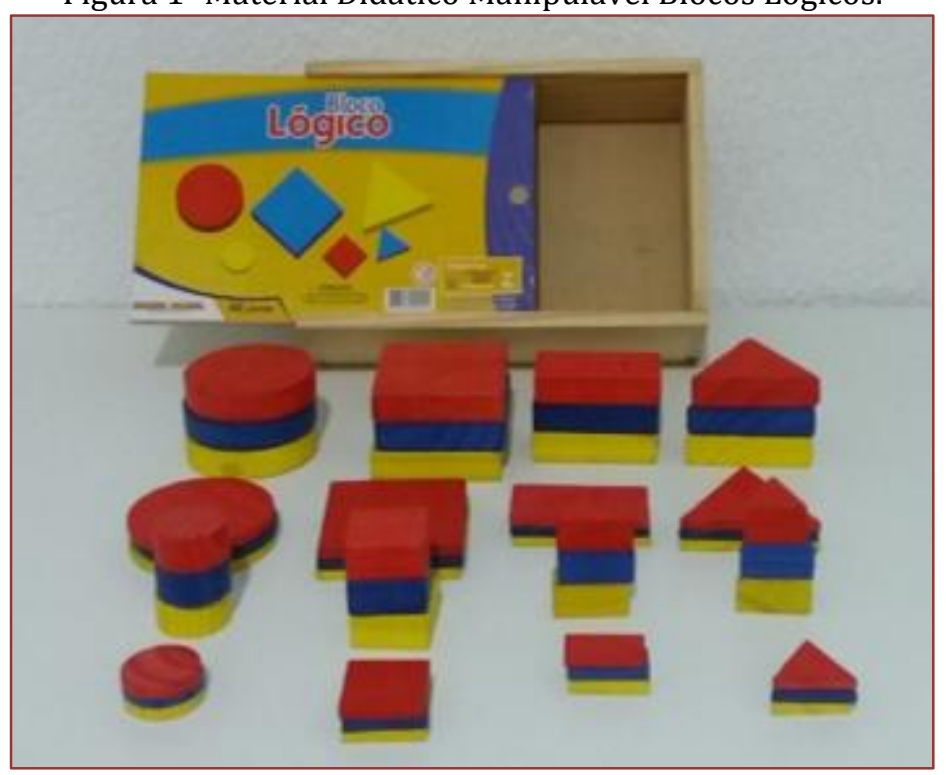

Fonte: Elaboração das autoras.

Inicialmente, deve-se apresentar esse material para as crianças e permitir que brinquem livremente para que possam se familiarizar com as peças e estabelecer suas próprias relações a partir de seus

\footnotetext{
4 De um modo geral, Piaget assim resumiu os estágios do desenvolvimento cognitivo: 1. 0 estágio da inteligência sensório-motora (0-2 anos); 2.0 estágio do pensamento pré-operacional (2-7anos);3. 0 estágio das operações concretas (7-11 anos); 4.0 estágio das operações formais (11-15 anos). (WADSWORTH,1996, p.17).

5 Neste trabalho as análises, quanto as formas, consideram as figuras planas identificadas a partir de uma face ou base desses sólidos geométricos.
} 
conhecimentos prévios ${ }^{6}$. Geralmente, constroem casas, carros, torres e figuras diversas relacionando-as com o mundo em que vivem e interagem. Assim, gradativamente, observam e exploram os atributos dos objetos.

Estudos têm mostrado que os Blocos Lógicos têm sido usados numa perspectiva que não valoriza suas reais potencialidades de proporcionar aprendizagens significativas para os alunos. Fala-se aqui da Matemática escolar, onde o trabalho pedagógico precisa estar ou deveria estar carregado de intencionalidades. Smole (1996c), enfatiza dizendo que "de nada valem os materiais didáticos na sala de aula se eles não estiverem atrelados a objetivos bem claros e seu uso ficar apenas restrito à manipulação ou ao manuseio que o aluno desejar fazer dele".

Alguns autores, destacando-se Toledo e Toledo (1997a), dizem que quase sempre esse material tem servido na escola apenas para ensinar às crianças na Educação Infantil as características de suas peças (cor, forma, tamanho e espessura), o que não evidencia as reais potencialidades do referido material para do desenvolvimento do raciocínio lógico-matemático. Esses mesmos autores evidenciam os Blocos Lógicos numa visão interessante, dizendo que:

No entanto, eles constituem um excelente material para trabalhar as noções de pertinência, inclusão, interseção, reunião e complementação, da teoria dos conjuntos, bem como o uso de conectivos lógicos (e, ou, se...então), da lógica matemática. (TOLEDO, 1997b, p. 32).

Diante dos processos de ensino e de aprendizagem do conceito número, alguns processos mentais precisam ser desenvolvidos pelas crianças, em sua estrutura cognitiva, para que a aprendizagem desse conceito ocorra de maneira significativa para ela e além disso, possibilite que percebam e se apropriem de possíveis desdobramentos conceituais que serão construídos no decorrer da sua vida escolar.

Dentre os processos mentais que norteiam a gênese do conceito de número, merece destaque seis deles: correspondência, comparação, classificação, ordenação, inclusão e conservação. É importante destacar que tais processos não acontecem cognitivamente isolados, pois são processos e não produtos com fim em si mesmos.

Pode-se descrever suscintamente algumas possibilidades de atividades que podem ser realizadas com esse material. Pode-se classificar as peças quanto ao tamanho e/ou forma. Agrupá-las quanto a cor, forma, tamanho e/ou espessura e assim trabalhar com noções de conjuntos. Relacionar cores e formas. Comparar quanto ao tamanho e/ou espessura. Possibilitar o desenvolvimento de noções de ordenação. Classificar quanto as cores. Estabelecer relação de pertinência entre um elemento e uma coleção.

Enfim, é necessário conhecer as potencialidades desse material para então planejar atividades pedagógicas coerentes com o seu uso diante do foco pretendido.

\subsection{POSSÍvEL RELAÇÃo ENTRE TECNOLOGIA E O MATERIAL DIDÁTICO MANIPULÁVEL BLOCOS LÓGICOS}

A proposta dessa relação entre tecnologia e materiais didáticos manipuláveis parece um tanto quanto desafiadora. No entanto, diante da realidade vivida atualmente, o uso das tecnologias digitais aparece cada vez mais presente na Educação Escolar.

Tal relação foi estabelecida neste trabalho, mediante a produção de um vídeo didático destinado para professores que ensinam matemática, principalmente na Educação Infantil e anos iniciais do Ensino Fundamental. É um recurso que pode possibilitar discussões a respeito, principalmente, do processo de construção do conceito de número pela criança e assim poderá possibilitar um novo fazer pedagógico diante do saber matemático em questão. Trata-se de um vídeo demonstrativo quanto ao uso dos Blocos Lógicos diante de situações relacionadas aos processos mentais de correspondência, comparação, classificação, ordenação, inclusão e conservação, relacionados ao desenvolvimento do raciocínio lógicomatemático.

0 estudo do uso de vídeos na educação não é algo novo, sendo já mencionado por Teixeira (1963), Moran (1995) e Ferrés (1996). E, com o advento das tecnologias digitais, o uso de vídeos deixa de ser apenas para a exibição em sala

\footnotetext{
${ }^{6}$ Segundo Moreira (2011), conhecimento prévio pode ser um símbolo já significativo, um conceito, uma proposição, um modelo mental, uma imagem.
} 
de aula e sua produção passa também a ser foco de estudos. (BORBA; OECHSLER; DOMINGUES, 2016, p. 1).

Intitulado, "O uso intencional do Blocos Lógicos na Educação Infantil: rumo à abstração", o vídeo tem a duração de aproximadamente sete minutos e nele é apresentada uma sequência de atividades que demonstram algumas possibilidades com o uso desse material diante de um fazer pedagógico intencional.

\section{ASPECTOS METODOLÓGICOS}

Este é um trabalho de sistematização de estudos realizados, durante o segundo semestre de 2019, no Curso de Mestrado Profissional em Ensino de Ciências e Matemática - MPECIM/UFAC, junto a uma turma de mestrandos no âmbito da disciplina Tecnologias e Materiais Curriculares para o Ensino de Matemática, na UFAC, orientada pela docente Salete Maria Chalub Bandeira.

Portanto, realizou-se uma pesquisa bibliográfica de cunho qualitativo visando subsidiar teoricamente algumas reflexões acerca do tema em questão. Para tanto, buscou-se um aporte teórico em leituras sobre a teoria construtivista de Piaget. Procurou-se também aporte teórico em outros autores a fim de melhor alicerçar esta produção.

\section{DESCRIÇÃO DA PRODUÇÃO DO VÍDEO}

Realizada a pesquisa bibliográfica, surgiu o desafio de se produzir um vídeo educativo sobre o uso dos Blocos Lógicos, pautado em um outro e possível fazer pedagógico. Assim, produziu-se um vídeo tendo como embasamento teórico os pressupostos da teoria construtivista piagetiana enfatizando os processos mentais básicos necessários para que a criança possa construir significativamente o conceito de número.

Na Figura 2 cenas do vídeo com as atividades de classificação e ordenação.

Figura 2- Atividades de classificação e ordenação - cenas do vídeo.

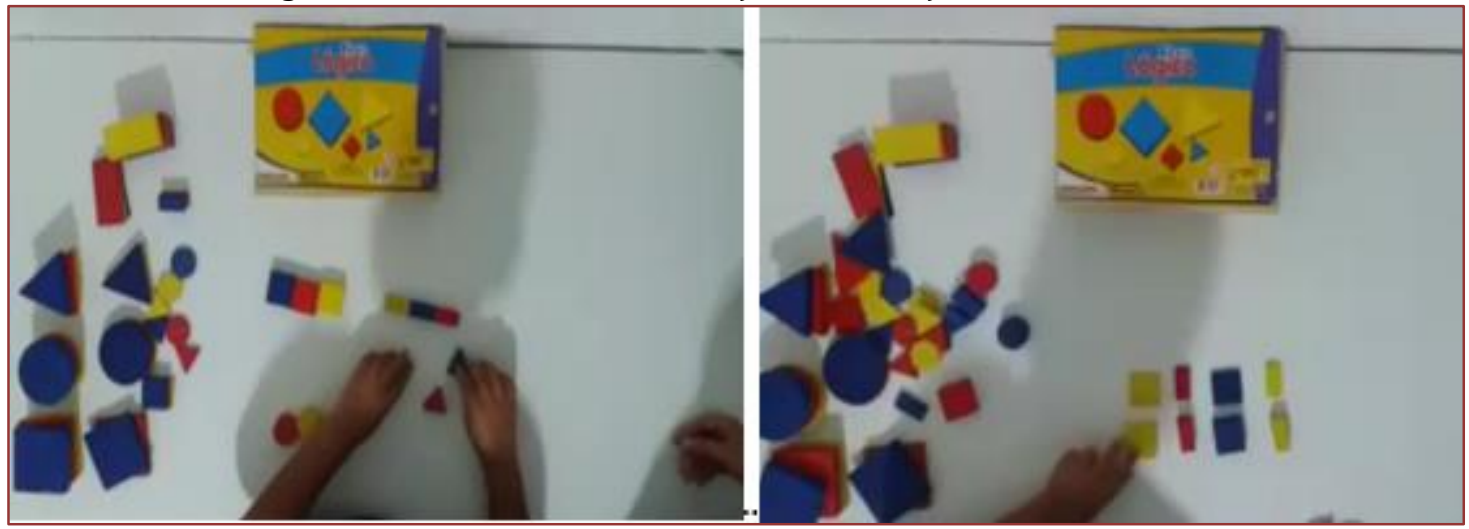

Fonte: Elaboração das autoras.

Classificar significa fazer agrupamentos de objeto com pelo menos um atributo. Podemos formar conjuntos pelos atributos forma, tamanho, cor e espessura. Segundo Moreno (2014, p. 28), "classificar significa apreender as propriedades de um grupo de objetos e, por meio desse conhecimento, decidir se um elemento pertence ou não a esse grupo; significa juntar por semelhanças e separar por diferenças". Já seriar significa "ordenar, colocar em ordem os elementos de um conjunto, decidindo o que vem antes e o que vem depois" (MORENO, 2014, p. 28). Podemos organizar os objetos do maior para o menor ou do mais pesado para o mais leve, no caso dos blocos lógicos pelo atributo forma, cor, espessura, tamanho.

Na Figura 3 os momentos da aula com os mestrandos do MPECIM/UFAC, com a apresentação do Vídeo intitulado, "O uso intencional do Blocos Lógicos na Educação Infantil: rumo à abstração": 
Figura 3 - Momentos da apresentação da aula no MPECIM/UFAC.

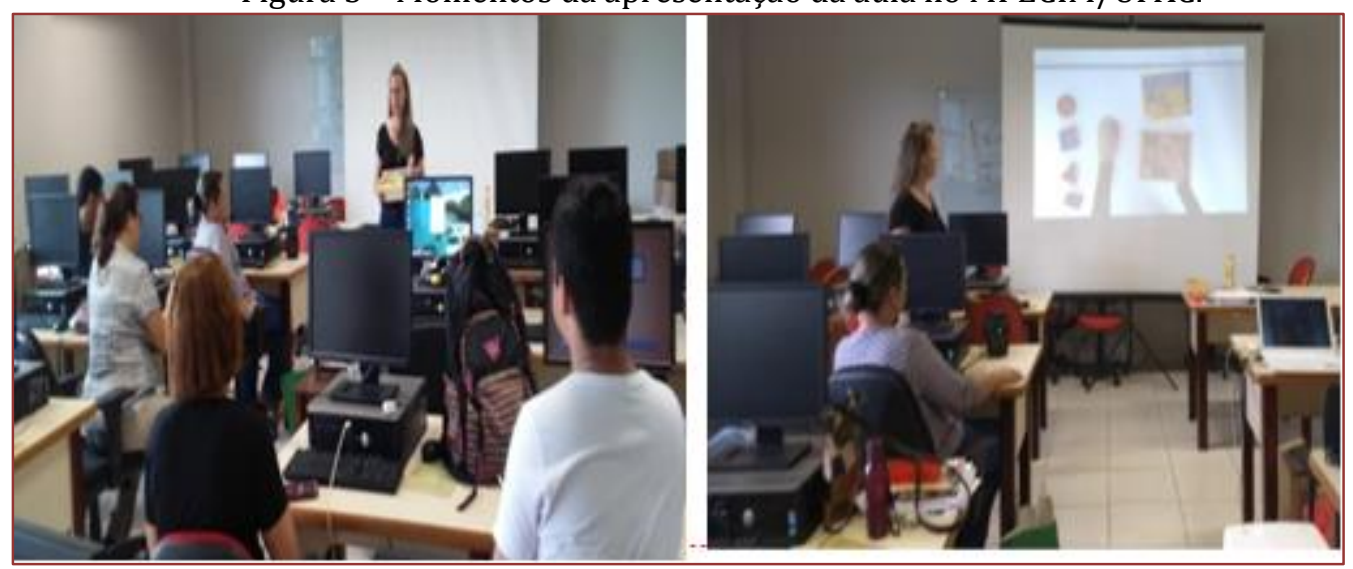

Fonte: Elaboração das autoras.

O material foi produzido artesanalmente com o uso de um smartphone Samsung Galaxy j5, um kit de Blocos Lógicos e um notebook.

O vídeo apresenta também um fundo musical instrumental extraído da internet/ youtube, cujo nome é "Música de fundo divertida para vídeos", localizado no endereço: https://www.youtube.com/watch?v=W6sk8szbFsQ e para a sua edição foi utilizado o software Windows Movie Maker 2016.

As cenas foram produzidas pela mestranda Wirla Castro de Souza Ramos, com a participação especial de um de seus filhos (sete anos de idade) que entusiasmadamente se disponibilizou a contribuir com a produção.

Esse vídeo, possibilitou que pesquisadores na área de Educação Matemática, que também são professores na educação básica, discutissem e refletissem sobre questões pertinentes as potencialidades pedagógicas que podem emergir a partir do uso intencional desse material didático manipulável frente ao saber matemático em questão.

\section{CONSIDERAÇÕES FINAIS}

Existem vários materiais didáticos manipuláveis que são importantes para o desenvolvimento do raciocínio lógico-matemático das crianças desde os seus primeiros anos de escolaridade, dentre eles destaca-se aqui os Blocos Lógicos.

Diante dos estudos realizados sobre esse material, pode-se dizer que seu uso pedagógico de maneira intencional, possibilita o desenvolvimento de processos mentais por parte das crianças que são necessários para a aprendizagem da Matemática Escolar, em especial para a construção significativa do conceito de número.

Pensar nas potencialidades pedagógicas desse material extrapola o seu simples manuseio. Demonstrou-se nesse estudo que é possível inclusive a produção de vídeo didático na intenção de oferecer mais uma alternativa para auxiliar na formação de professores que ensinam matemática desde a Educação Infantil.

\section{REFERÊNCIAS}

[1] Amadeu, Maria Simone Utida dos Santos. et al. Manual de normatização de documentos científicos de acordo com as normas da ABNT. Curitiba: Ed.UFPR, 2015.

[2] Borba, Marcelo de Carvalho.et al. Vídeos em Educação Matemática e suas potencialidades como tutorial. In: Encontro Nacional de Educação Matemática, XII, 2016, São Paulo.

[3] Kamii, Constance; Livingston, Sally Jones. Desvendando a aritmética: Implicações da teoria de Piaget. São Paulo: Papirus, 1995.

[4] Macedo, Lino de. Ensaios Construtivistas. São Paulo: Casa do Psicólogo, 2010. 
[5] Moreira, Marco Antônio. Aprendizagem Significativa: a teoria e textos complementares. São Paulo: Editora Livraria Física, 2011.

[6] Moreno, Heliete Martins Castilho. Mundo Social: Pensamento Matemático I Aritmética. Universidade Federal do Mato Grosso - UFMT, Ministério da Educação, Universidade Aberta do Brasil. Cuiabá - Mato Grosso, 2014.

[7] Nunes, Terezinha; Bryant, Peter. Crianças fazendo matemática. Porto Alegre: Artes Médicas,1997.

[8] Ramos, Wirla Castro de Souza; Bandeira, Salete Maria Chalub. O Uso Intencional Dos Blocos Lógicos: reflexões e possibilidades na educação infantil. In: Encontro Nacional de Educação Matemática, 13, 2019, Cuiabá. Anais [...]. Cuiabá-MT: Arena Pantanal. ISSN 2178-034X. p. 1-8.

[9] Smole, Kátia Cristina Stocco. A Matemática na Educação Infantil: a teoria das inteligências mútiplas na prática escolar. Porto Alegre: Artes Médicas, 2000.

[10] Toledo, Marília; Toledo, Mauro. Didática de Matemática: como dois e dois. São Paulo: FTD, 1997.

[11] Wadsworth, Barry J. Inteligência e afetividade da criança na teoria de Piaget. São Paulo: Pioneira,1996. 


\section{Capítulo 3}

Operando com números naturais nos anos iniciais do Ensino Fundamental: Um olhar sob as lentes da teoria das situações didáticas

\section{Wirla Castro de Souza Ramos}

Itamar Miranda da Silva

Resumo: Neste artigo, trazemos algumas discussões de uma pesquisa de mestrado em andamento, que tem por objetivo compreender de que maneira a Teoria das Situações Didáticas (TSD), proposta por Gay Brousseau, pode contribuir para o ensino das operações aritméticas, envolvendo números naturais, no contexto dos anos iniciais do Ensino Fundamental. Tendo em vista a natureza desta pesquisa, a metodologia de investigação que adotaremos terá como base uma abordagem qualitativa de cunho descritivo e interpretativo, baseada no Percurso de Estudo e Pesquisa (PEP), proposta por Chevallard. Os sujeitos da pesquisa serão professores que ensinam Matemática em uma das escolas públicas da cidade de Rio Branco/AC. Esperamos que esse trabalho possa constituir-se em uma proposta de ensino e suscitar outras pesquisas que contribuam com uma Educação Básica que de fato representa tanto para estudantes quanto para professores a sua razão de ser.

Palavras-chave: Operações aritméticas; Teoria das Situações Didáticas; Ensino Fundamental; Percurso de Estudo e Pesquisa. 


\section{INTRODUÇÃO}

Atualmente, dentre os temas abordados pelas investigações científicas, vemos o crescente interesse de educadores e pesquisadores pela área de Educação Matemática. Talvez, isso se justifica por percebemos que a Matemática escolar tem se mostrado como um ponto de reflexão sobre as práticas pedagógicas vigentes, que parecem andar na contramão no que diz respeito à formação de cidadãos conscientes e participantes $\mathrm{da} /$ na sociedade.

Diante disso, nessa proposta de pesquisa, daremos ênfase à Matemática escolar, tendo como foco, o ensino das operações aritméticas (adição, subtração, multiplicação e divisão), envolvendo números naturais nos anos iniciais do Ensino Fundamental.

Vale dizer que a delimitação desse objeto de conhecimento matemático, justifica-se pela sua importância e ligação com os outros conhecimentos que serão construídos pelo aluno, durante seus anos de escolaridade.

A pesquisa tem como aporte teórico, a Teoria das Situações Didáticas (TSD), proposta por Gay Brousseau (1986 apud ALMOULOUD 2007), que fundamenta a estrutura formada pelo sistema didático, considerando as interações entre professor e alunos, mediadas pelo saber nas situações de ensino, visando a aprendizagem significativa. Logo, tentaremos compreender como a TSD pode contribuir para o ensino das operações aritméticas, com números naturais, nos anos iniciais do Ensino Fundamental.

Elegemos como estratégia metodológica, o Percurso de Estudos e Pesquisa ${ }^{7}$ (PEP), proposto por Chevallard (2009), onde será possível realizarmos uma pesquisa de cunho qualitativo, baseada em questionamentos e reflexões das práticas docentes.

Evidenciaremos o caráter singular do mestrado profissional, no que diz respeito a ações efetivas, que possam contribuir com a formação docente e nas práticas pedagógicas na Educação Básica. Apresentaremos um Produto Educacional, composto por Situações Didáticas, baseadas nos pressupostos da TSD, tendo em vista o objeto de conhecimento matemático em questão.

\section{ALGUMAS CONSIDERAÇÕES SOBRE A TEORIA DAS SITUAÇÕES DIDÁTICAS (TSD)}

Temos a Didática da Matemática (DM) como campo específico de estudos que se atém aos processos de ensino e aprendizagem. Decorre, então, que daremos ênfase à Teoria das Situações Didáticas (TSD) desenvolvida por Guy Brousseau (2006), uma vez que, nessa perspectiva, o sujeito cognitivo não é o foco pretendido, mas sim as situações pensadas e organizadas pelo professor, a fim de proporcionar aprendizagens significativas para os sujeitos do processo, diante da especificidade do conhecimento ensinado.

Diante da Teoria das Situações Didáticas (TSD), proposta por Gay Brousseau (2006), podemos dizer que esta tem como objeto central de estudo, as situações didáticas em que ocorre as relações entre professoraluno-saber, considerando o milieu ${ }^{8}$ intencional, onde as aprendizagens se desenrolam e os conhecimentos são construídos de maneira significativa tanto para o aluno quanto para o professor.

O objetivo da Didática da Matemática é criar situações para difundir o conhecimento matemático sistematizado, tendo como ênfase, nesse estudo, a Matemática Escolar. A relação pedagógica, que comumente se evidencia na escola, parece ser binária - professor e aluno, se observada rápida e empiricamente. Entretanto, diante da proposta da TSD, essa relação é ternária - professor- aluno- saber. Nesse contexto, a problematização das tarefas matemáticas, de maneira intencional, em situações didáticas, parece se configurar como uma necessidade para levar o aluno a se relacionar com a Matemática Escolar, de maneira significativa.

Corroborando com o que vem sendo colocado a respeito da TSD, Almouloud (2007) diz que:

0 objeto central de estudo nessa teoria não é o sujeito cognitivo, mas a situação didática na qual são identificadas as interações estabelecidas entre professor, aluno e saber. Brousseau (1986) procura teorizar os fenômenos ligados a essas interações, buscando a especificidade do conhecimento ensinado, para isso, considera como fundamental a estrutura formada pelo sistema minimal:

\footnotetext{
${ }^{7}$ Usaremos a sigla PEP que significa Percurso de Estudo e Pesquisa, mas Chevallard (2009) denominou PER (Parcours d'Etude et de Recherche).

${ }^{8}$ Segundo Brousseau (1986) milieu é constituído de todas as relações que o aluno estabelece dentro e fora da escola.
} 
sistema didático stricto sensu, consideradas aqui as interações entre professor e alunos mediadas pelo saber nas situações de ensino. (ALMOULOUD, 2007, p.32).

Considerando as operações aritméticas fundamentais, a questão que se destaca, mediante essas reflexões, é a relevância de se dar a razão de ser a elas, diante de outros objetos matemáticos, como exemplo: dar sentido à adição, ao tratar do perímetro de formas geométricas; à multiplicação, ao abordar tarefas envolvendo áreas de figuras planas; à subtração, ao comparar gráficos estatísticos; à divisão, na organização da turma em grupos para realização de determinadas tarefas; ou seja, pretendemos desenvolver um trabalho não na perspectiva do conceito em si, mas das ideias que perpassam os conceitos aritméticos, e que podem vir a ser uma âncora para novas aprendizagens.

Com efeito, as operações aritméticas (adição, subtração, multiplicação e divisão) em si, serão utilizadas como ferramentas e é na relação matemática e didática, intencionalmente pensada, considerando o sistema didático: saber-aluno-professor, que as situações didáticas podem dar sentido a elas e, assim, possibilitarão que o aluno aprenda esses conceitos aritméticos.

Podemos dizer que a situação didática é o objeto central da teoria das situações, que é assim definida por Brousseau (1978 apud ALMOULOUD, 2007):

O conjunto de relações estabelecidas explicitamente e/ou implicitamente entre um aluno ou um grupo de alunos, um certo milieu (contendo eventualmente instrumentos ou objetos) e um sistema educativo (o professor) para que esses alunos adquiram um saber constituído ou em constituição. (ALMOULUOD, p.33).

Além das situações previstas durante os processos de ensino e aprendizagem, é preciso considerar, também, a existência de situações que, mesmo contribuindo para a formação de conceitos, não estão sob o controle pedagógico do professor. Assim, o desafio didático consiste em prever alguns elementos indicativos de uma possível progressão da aprendizagem escolar para situações em que não há controle direto do professor. É aqui que aparece a noção de situações adidáticas, descrita por Brousseau (1986), como situações em um ambiente de aprendizagem, onde falta a intencionalidade explícita, mostrando que considerar tais situações possibilita ultrapassar a velha concepção de que o professor seja apenas um transmissor de conhecimento.

Na Didática da Matemática, a intenção educacional pode ser evidenciada na iteração entre o didático e o adidático. Parece necessário se estabelecer uma relação ente as variáveis que estão sob o controle do professor e aquelas que, mesmo sem o controle direto, podem orientar os processos de ensino e aprendizagem do conhecimento em questão. Assim, o professor assume o papel de orientador das atividades de ensino, prevendo, em seu planejamento, outras possíveis situações.

De acordo com Brousseau (1986 apud PAIS, 2001):

Quando o aluno se torna capaz de colocar em funcionamento e utilizar por ele mesmo o conhecimento que ele está construindo, em situação não prevista de qualquer contexto de ensino e também na ausência de qualquer professor, está ocorrendo então o que se pode ser chamado de situação adidática. (BROUSSEAU, 1986 citado por PAIS, 2001, p. 68).

Podemos dizer que, outra importante proposição da TSD, é a ideia de contrato didático, pois Brousseau (1986 apud ALMOULOUD, 2007) diz que faz-se necessário distinguir contrato didático de contrato pedagógico, para que se possa compreender a ideia que norteia essa teorização, uma vez que, nesse último caso, nas relações entre os atores, não se evidencia o saber em jogo, mas apenas as relações sociais, atitudes, regras e convenções.

Outra questão importante, diz respeito ao funcionamento do contrato didático, que depende dos diferentes contextos de ensino e de aprendizagem, que podem evidenciar as escolhas pedagógicas, as propostas de atividades, as condições de avaliação, a relação professor-aluno, etc.

Na perspectiva das relações entre professor-aluno-saber, o contrato didático nem sempre desencadeia situações exitosas de aprendizagem e pode acontecer a necessidade de renegociações, quando isso acarreta dificuldades para a aprendizagem de novos conhecimentos matemáticos. Parece pertinente dizer que esse contrato, segundo Chevallard (1986 apud D’AMORE 2007 p.107), não se configura em uma realidade estável, mas sim uma realidade em constante evolução. 
Dada à importância do conceito e do entendimento de contrato didático, tendo em vista a TSD, vale destacar que o estudo desse conceito possibilita evidenciar incoerências que por vezes acontecem nos processos de ensino e de aprendizagem, no que diz respeito às expectativas do professor, quando organiza um mellieu, visando produção de conhecimento de maneira autônoma pelo aluno. Como diz Amouloud (2007, p.93), o conceito de contrato didático permite analisar e interpretar os fenômenos não evidentes nos processos de ensino e de aprendizagem.

A responsabilidade da coordenação e organização dos processos de ensino é do professor. Brousseau ressalta o paradoxo existente nas situações pertinentes ao contrato didático, pois o professor tem responsabilidades diferentes do aluno. Enquanto mediador na relação didática, ele não pode minar as condições que viabilizam a construção do conhecimento pelo aluno, tirando-o a oportunidade de aprender.

\section{A PROPOSIÇÃO DE SITUAÇõES DIDÁTICAS ENVOLVENDO AS OPERAÇÕES ARITMÉTICAS}

Temos as operações aritméticas como objetos matemáticos evidenciados em nossa proposta de pesquisa. Tendo em vista as proposições da TSD e o percurso metodológico pretendido (PEP), vivenciaremos, junto aos sujeitos da pesquisa, momentos de análise e reflexão, de como esses objetos matemáticos aparecem e se configuram nas respectivas práticas docentes e nos momentos em que as proposições da pesquisa serão evidenciadas, nas Situações Didáticas, pensadas a partir da teorização em questão.

Apresentaremos um conjunto de Situações Didáticas, que possibilitarão a discussão e a reflexão entre os participantes, tendo como foco o ensino das operações aritméticas e, consequentemente, a aprendizagem desses objetos matemáticos.

A intenção é a elaboração e a proposição de Situações Didáticas que possam possibilitar que, desde o início da escolaridade, os alunos percebam as conexões que existem entre os conceitos matemáticos e, ainda, a relevância e ligação das operações aritméticas com praticamente todos os saberes matemáticos que serão construídos pelo aluno, no decorrer da sua vida escolar. Assim, durante o desenvolvimento das situaçõesproblema, esperamos que o professor oportunize aos alunos que recorram às noções matemáticas permeadas pelas operações aritméticas, além de possibilitar que conheçam e se apropriem da linguagem estabelecida para essa área do conhecimento.

\section{METODOLOGIA}

Levaremos em consideração a natureza desta pesquisa e adotaremos a metodologia baseada em uma abordagem qualitativa de cunho descritivo e interpretativo, configurando-se na proposta metodológica, encontrada em Chevallard (2009) e conhecida como Percurso de Estudos e Pesquisas (PEP), que propicia situações de questionamentos das práticas docentes vigentes, levando o professor à reflexão dos paradigmas, pautados em práticas baseadas na fragmentação dos saberes referente a objetos matemáticos escolares e em práticas meramente reprodutoras. Silva $(2014$, p.120), diz que esse modelo metodológico tem origem em uma pedagogia do questionamento e se desenvolve no contexto do sistema didático $\mathrm{S}(\mathrm{X}, \mathrm{Y}$, $\mathrm{Q}_{0}$ ), onde $\mathrm{X}$ pode ser um grupo de alunos, professores, pesquisadores, Y pode ser um conjunto unitário, daquele que coordena o estudo, por exemplo, o coordenador da pesquisa e $Q_{0}$ é a questão geradora das subquestões. Temos então, $\mathrm{Q}_{0}=$ De que maneira a Teoria das Situações Didáticas pode contribuir para o ensino das operações aritméticas, envolvendo números naturais, no contexto dos anos iniciais do Ensino Fundamental? Portanto, essa é a questão geradora que buscaremos investigar no processo dialógico a ser estabelecido entre X e Y.

Em nossa pesquisa, $\mathrm{X}$ serão quatro professores que ensinam matemática, nos anos iniciais do Ensino Fundamental, em uma das escolas públicas da cidade de Rio Branco/AC e Y, pela pesquisadora.

Para materializar a pesquisa, realizaremos entrevista semiestruturada com os membros de X, observaremos a rotina de seus planejamentos pedagógicos para as aulas de matemática e analisaremos como as operações aritméticas estão referenciadas nos documentos oficiais da educação brasileira (BNCC e PCNs).

Na composição do nosso Produto Educacional, nos basearemos no PEP e nas reflexões, a partir das informações e vivências com os professores, para apresentar uma Sequência Didática composta por Situações Didáticas, tendo em vista as proposições da TSD de Guy Brousseau. 


\section{BREVES CONSIDERAÇÕES SOBRE O PRODUTO EDUCACIONAL}

Estamos desenvolvendo a pesquisa no contexto de um Mestrado Profissional em ensino de Matemática onde os produtos educacionais se constituem em requisito indispensável para a conclusão do mesmo. Eles têm como objetivo principal, atender a estreita relação existente este tipo de Mestrado e a práticas pedagógicas em sala de aula, em diferentes contextos de ensino e aprendizagem.

Iremos apresentar para os professores, uma Sequência Didática que pode possibilitar o ensino e, consequentemente, a aprendizagem das operações aritméticas, envolvendo números naturais, no contexto dos anos iniciais do Ensino Fundamental.

As operações aritméticas, objeto matemático dessa pesquisa, podem aparecer nas situações didáticas desde o início da escolaridade, pois isso pode possibilitar que os alunos percebam as conexões que existem entre os conceitos matemáticos, e ainda, a relevância e ligação das operações aritméticas com praticamente todos os saberes matemáticos que serão construídos no decorrer da sua vida escolar. Assim, durante o desenvolvimento das situações-problema (tarefas), o professor oportuniza aos alunos que recorram às noções matemáticas que permeiam as operações aritméticas, além de possibilitar que conheçam, se apropriem e ampliem o conhecimento da linguagem envolvida na Matemática Escolar.

Com a finalidade de ampliar a ideia sobre situação didática, no sentido do que queremos construir, tentaremos levar o professor compreender que os alunos precisam apresentar e organizar, por exemplo, as preferências de lanche escolar, e perceber, nesse caso, que as questões relacionadas à unidade temática "estatística" estarão evidenciadas. Nesse contexto, noções pertinentes às operações aritméticas emergirão, quando os alunos forem comparar as informações obtidas no grupo. Terão que ora adicionar ou subtrair, ora multiplicar ou dividir.

\section{CONSIDERAÇÕES FINAIS}

Objetivando redimensionar o olhar para o ensino e aprendizagem desses objetos de conhecimento, estamos propondo uma pesquisa de cunho qualitativo, baseado no que preconiza a Didática da Matemática, quanto aos processos de ensino dos objetos de conhecimentos matemáticos.

Vale frisar que, o foco será dado ao papel do professor, enquanto mediador dos processos de ensino e de aprendizagem, tendo como suporte teórico a TSD proposta por Guy Brousseau.

A TSD constitui-se em uma teoria que situa um determinado objeto de ensino e, em nosso caso, está focada nos saberes matemáticos que podem envolver as quatro operações. Então, esse construto teórico foi desenvolvido para compreender as relações que acontecem entre alunos, professor e o saber em sala de aula.

Estaremos propondo um dispositivo didático, que se constituirá enquanto uma Sequência Didática, que pode possibilitar o ensino das operações aritméticas (adição, subtração, multiplicação e divisão) envolvendo números naturais, nos anos iniciais do Ensino Fundamental, através de situações didáticas, com foco nos anos iniciais (primeiro e segundo anos).

Esperamos que esse trabalho possa constituir-se em uma proposta de ensino e suscite outras pesquisas que possam contribuir com uma Educação Básica de qualidade. Portanto, o percurso, até o momento, guiado pela TSD, tem possibilitado apresentar um dispositivo didático, com potencialidades para enfrentar algumas restrições encontradas pelos professores, em sua prática pedagógica, para abordarem o ensino das operações fundamentais.

\section{REFERÊNCIAS}

[1] Almouloud, Saddo Ag. Fundamentos da didática da matemática. Curitiba: UFPR,2007.

[2] Brousseau, Guy. A Teoria das Situações Didáticas e a Formação do Professor. Palestra. São Paulo: PUC, 2006.

[3] D’amore, Bruno. Elementos de Didática da Matemática. São Paulo: Editora Livraria da Física, 2007.

[4] Moreira, Marco Antônio. Aprendizagem Significativa: a teoria e textos complementares. São Paulo: Editora Livraria Física, 2011.

[5] Pais, Luiz Carlos. Didática da Matemática: Uma análise da influência francesa. Belo Horizonte: Autêntica, 2001. 
[6] Ramos, W.C.S.; Silva, I.M. As operações aritméticas nos anos iniciais do Ensino Fundamental: reflexões à luz da Teoria das Situações Didáticas. In: V Colóquio de Matemática da Região Norte, 2019, Rio Branco: Ufac.

[7] Silva, I.M. A Relação do Professor com o Saber Matemático e os Conhecimentos Mobilizados em sua Prática. 215f. Tese (Doutorado em Educação) - Área de concentração Educação Matemática, Universidade Federal do Pará, 2014. 


\section{Capítulo 4}

o uso do material dourado manipulável e da tecnologia no ensino dos números decimais para alunos do $6^{\circ}$ ano

Viviane Menezes de Souza Machado

Salete Maria Chalub Bandeira

Resumo: 0 presente artigo tem como objetivo descrever como o uso do material dourado, a produção de vídeos, e do jogo, potencializam o ensino de números decimais numa turma do $6^{\circ}$ ano do Ensino Fundamental da Escola de Educação Básica e Profissional Fundação Bradesco em Rio Branco-AC, no 4ํㅡㄹ bimestre do ano de 2018. Trata-se de um estudo de caso, com abordagem qualitativa, onde foram realizadas sequências didáticas com o material dourado manipulável, produção de vídeos usando esse material e a utilização do jogo Mina dos números decimais, do site www.matematicazup.com.br, envolvendo representação, adição e subtração de números decimais. Meus instrumentos para análise foram os registros dos alunos nos vídeos e no caderno. 0 trabalho realizado mostra que o uso do material manipulável, do recurso tecnológico do jogo e dos vídeos, tornaram as aulas mais atrativas e significativas para os alunos, tendo assim, uma aprendizagem eficaz.

Palavras-chave: Materiais manipuláveis; Tecnologia; Números Decimais; Aprendizagem. 


\section{INTRODUÇÃO}

A cada dia vemos a necessidade dos professores procurarem novas estratégias na forma de ensinar os conteúdos em sala de aula, a fim de garantir a aprendizagem dos alunos.

Ao ministrar o conteúdo de números decimais para o 6o ano, percebia a dificuldade que muitos alunos tinham em representá-los na forma fracionária, na forma decimal, compará-los e também em resolver cálculos envolvendo adição e subtração.

Este artigo visa divulgar os resultados obtidos em atividades realizadas com uma turma de 39 alunos do 6o ano da Escola de Educação Básica e Profissional Fundação Bradesco, durante as duas primeiras semanas do 4 o bimestre de 2018, envolvendo parte do conteúdo de números decimais. Para a realização dessas atividades, foram utilizados kits de material dourado manipulável, celulares dos alunos para a produção de vídeos e o jogo Mina dos números decimais, disponível no endereço: https://matematicazup.com.br/.

Além de tornar as aulas mais atrativas e significativas, pretende-se verificar como o uso do material dourado manipulável, produção de vídeos e o jogo, potencializam o ensino dos números decimais com alunos do 6음 ano do Ensino Fundamental.

\subsection{MATERIAL DOURADO}

Quem criou este material foi Maria Montessori. Segundo Daltoé e Strelow (2010):

Maria Montessori (1870-1952), nasceu na Itália, interessou-se pelo estudo das ciências, mas decidiu-se pela Medicina, na Universidade de Roma. Direcionou a carreira para a psiquiatria, e logo se interessou por crianças deficientes. A grande contribuição de Maria Montessori à moderna pedagogia foi a tomada de consciência da criança, percebendo que essas respondiam com rapidez aos estímulos para realizar tarefas, exercitando as habilidades motoras e experimentando autonomia.

Inicialmente esse material foi criado para auxiliar em atividades envolvendo o sistema de numeração decimal-posicional e nas quatro operações fundamentais da Matemática. Segundo Freitas (2004), a utilização desse material evoluiu, e hoje podemos usá-lo para o estudo das frações, raiz quadrada, cálculo de área e volume, números decimais e outras atividades criativas.

Sua construção seguiu os mesmos princípios montessorianos, a educação sensorial: desenvolver na criança a independência, a confiança em si mesma, a concentração, a coordenação e a ordem; gerar e desenvolver experiências concretas estruturadas e conduzir gradualmente a abstrações cada vez maiores; fazer a criança, por ela mesma, perceber os possíveis erros que comete ao realizar uma determinada ação com o material e trabalhar com os sentidos da criança.

Atualmente este material, conhecido como Material Dourado, feito em madeira, é trabalhado no formato da Figura 1:

Figura 1- Material Dourado.

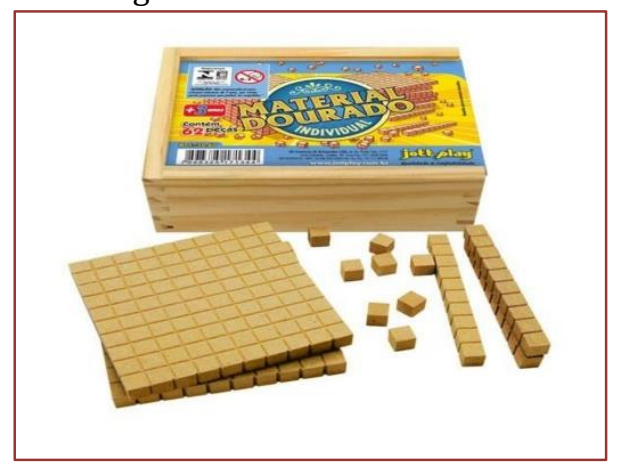

Fonte: www.dafiti.com.br 
O Material Dourado faz a ponte entre o abstrato e o concreto, o que facilita bastante a compreensão dos alunos nas atividades, além de tornar as aulas mais interessantes.

\section{2 . 0 USO DA TECNOLOGIA NA SALA DE AULA}

Vivemos em um mundo globalizado, onde a tecnologia está muito presente no nosso cotidiano. No contexto escolar não seria diferente. Precisamos inserir essas novas tecnologias nas aulas, com o propósito de orientar melhor os alunos no processo de formação da cidadania e na construção do aprendizado.

Segundo Freire (2000, p. 102):

[...] o exercício de pensar o tempo, de pensar a técnica, de pensar o conhecimento enquanto se conhece, de pensar o quê das coisas, o para quê, o como, o em favor de quê, de quem, o contra quê, o contra quem são exigências fundamentais de uma educação democrática à altura dos desafios do nosso tempo.

Sendo assim, os professores tem um papel fundamental na produção da proposta pedagógica da escola, pois a mesma precisa estar norteada pela aquisição de uma linguagem tecnológica, fazendo uma relação crítico produtiva entre o aprendizado escolar e o surgimento das novas tecnologias. Todos os recursos midiáticos da escola precisam estar centrados na aprendizagem do fazer saber, relacionando o mundo tecnológico com o mundo educacional.

Estes recursos tornam a prática de ensinar e aprender motivadora, lúdica e variada. De acordo com Anacleto, Michel e Otto (2007, p.22):

O mundo caminha para a era do domínio de novas tecnologias, novas mídias surgem a cada dia, e sob este contexto o ensino deve também sofrer avanços, adaptar-se as novas linguagens e formas de conhecimento, assim como se tornar mais atraente, dinâmico e que facilite o processo de aprendizagem do educando, sob este aspecto, novas mídias educacionais ganham destaques, ou ainda mídias seculares ganham nova importância educacional, entre as quais está o cinema, que pode ser um poderoso instrumento de apoio magistério.

Cabe à escola, na figura do professor, verificar quais mídias dá oportunidade ao aluno de investigar e refletir seu aprendizado frente às temáticas que o cerca. Não podemos mais adiar a inclusão destas tecnologias, pois o educando não é mais o mesmo. Segundo Cortês (2009, p.18):

Atualmente, não podemos mais adiar o encontro com as tecnologias; passíveis de aproveitamento didático, uma vez que os alunos voluntários e entusiasticamente imersos nesses recursos - já falam outra língua, pois desenvolveram competências explicitadas para conviver com eles.

0 avanço tecnológico, principalmente da internet, faz com que o professor deixe de ser apenas um transmissor de conhecimento, e passe a ser um mediador crítico, capaz de articular seus saberes as novas mídias presentes.

\section{FUNDAMENTAÇÃO TEÓRICA}

Em vários conteúdos de matemática é necessária a utilização de algo concreto para que o aluno, ao manipular, formule conceitos e relacione com conhecimentos já adquiridos no cotidiano.

Segundo Lorenzato (2006, p. 9), "os materiais devem visar mais diretamente à ampliação de conceitos, à descoberta de propriedades, à percepção da necessidade do emprego de termos ou símbolos, à compreensão de algoritmos, enfim, aos objetivos matemáticos".

Além do material dourado manipulável, o jogo e as produções de vídeos potencializam o aprendizado deste conteúdo, pois essas mídias estão presentes no cotidiano do aluno, tornando a aula atrativa e inovadora.

Para Oliveira $(2007$, p.5):

Ensinar Matemática é desenvolver o raciocínio lógico, estimular o pensamento independente, a criatividade e a capacidade de resolver problemas. Os educadores matemáticos devem procurar alternativas que motivem a 
aprendizagem e, desenvolvam a autoconfiança, a organização, a concentração, estimulando as interações do sujeito com outras pessoas.

O aluno de hoje tem a tecnologia presente em vários momentos de sua rotina diária. Não seria diferente na escola. Nós professores, precisamos aliar esse avanço tecnológico com a nossa metodologia em sala de aula, tornando-as mais atrativas e desafiadoras.

Segundo Kenski (2007, p.19),

[...] as tecnologias invadem nossas vidas, ampliam a nossa memória, garantem novas possibilidades de bem-estar e fragilizam as capacidades naturais do ser humano. Somos muito diferentes dos nossos antepassados e nos acostumamos com alguns confortos tecnológicos - água encanada, luz elétrica, fogão, sapatos, telefone - que nem podemos imaginar como seria viver sem eles.

A tecnologia bem utilizada nas aulas, será uma excelente ferramenta para o processo de ensino e aprendizagem.

Infelizmente, muitos professores evitam utilizar a tecnologia em sala de aula. Uns porque não sabem utilizar, outros porque acham que essas ferramentas, principalmente o celular, tiram a atenção do aluno.

Para que haja uma aprendizagem significativa são recomendadas por Santos (2008), sete atitudes nos ambientes de aula:

1. Dar sentido ao conteúdo: toda aprendizagem parte de um significado contextual e emocional.

2. Especificar: após contextualizar, o educando precisa ser levado a perceber as características específicas do que está sendo estudado.

3. Compreender: é quando se dá a construção do conceito, que garante a possibilidade de utilização do conhecimento em diversos contextos.

4. Definir: significa esclarecer um conceito. 0 aluno deve definir com suas palavras, de forma que o conceito lhe seja claro.

5. Argumentar: após definir, o aluno precisa relacionar logicamente vários conceitos e isso ocorre por meio do texto falado, escrito, verbal e não verbal.

6. Discutir: nesse passo, o aluno deve formular uma cadeia de raciocínio pela argumentação.

7. Levar para a vida: o sétimo e último passo da (re) construção do conhecimento é a transformação. 0 fim último da aprendizagem significativa é a intervenção na realidade. Sem esse propósito, qual aprendizagem é inócua. (SANTOS, 2008, p.73-74).

\section{ASPECTOS METODOLÓGICOS}

Nas sequências didáticas apresentadas neste artigo, foi utilizado o material dourado manipulável para a compreensão das representações decimais, finalizando com as produções dos vídeos pelos alunos utilizando o celular, bem como a utilização do jogo Mina dos números decimais, para a compreensão da adição e subtração desses números.

Essas sequências foram realizadas em seis aulas. Na primeira aula, a turma foi dividida em grupos de quatro componentes, onde cada grupo recebeu um kit contendo o material dourado, o qual deveria ser utilizado para a resolução de algumas perguntas que fiz no quadro, abordando a representação e comparação de números decimais. Na segunda aula, cada grupo falou como fez para responder as questões propostas utilizando o material dourado, demonstrando para os demais colegas da turma. Na terceira aula e quarta aula, os mesmos grupos produziram vídeos demonstrando como utilizaram o material dourado para representar e comparar números decimais nas atividades propostas. Na quinta aula, levei os alunos para o laboratório de informática, onde os mesmos utilizaram o jogo Mina dos números decimais, do site www.matematicazup.com.br, o qual trabalha adição e subtração de números decimais.

Este jogo é dividido em dez fases. Em cada fase o aluno tem que conseguir três estrelas, cada uma será conquistada se o cálculo for resolvido corretamente. 0 tempo em cada fase vai reduzindo, forçando o 
aluno a fazer cálculos mentais de adição com decimais de forma rápida para ajudar duas toupeiras que transportam pedras nessa Mina. 0 objetivo do jogo é calcular a soma dos números decimais, chegando à placa com o resultado da operação e, em seguida, direcionar os trilhos até a sua chegada.

Na última aula, foi feita uma discussão em sala, onde foi mostrado no Data Show as questões que os alunos tiveram mais dificuldades no jogo, dando oportunidade de fala para aqueles que tinham compreendido e questionando o restante.

Vale ressaltar que todas as atividades feitas, dependiam de um conhecimento prévio, tanto com os números decimais, quanto ao manuseio de recursos tecnológicos. Ausubel, Novak e Hanesian (1893), enfatizam que "o fator mais importante que influi na aprendizagem é aquilo que o aluno já sabe". Nas fotos 1,2 e 3, o registro de algumas ações desenvolvidas nas aulas.

Foto 1 - Utilização do material dourado.

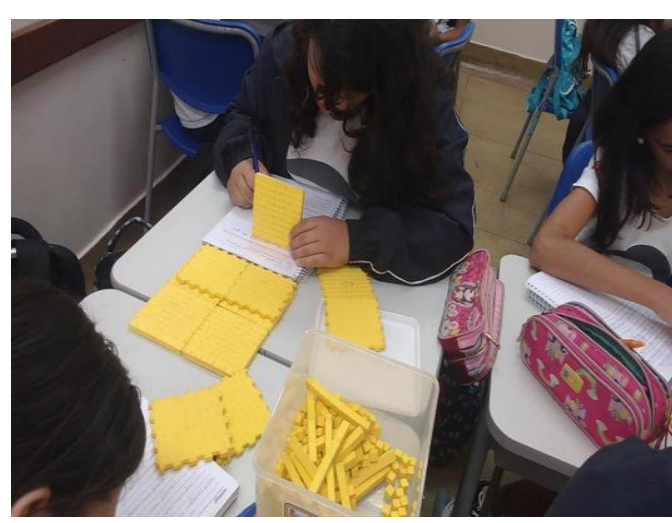

Foto 2 - Atividade resolvida com o uso do material.

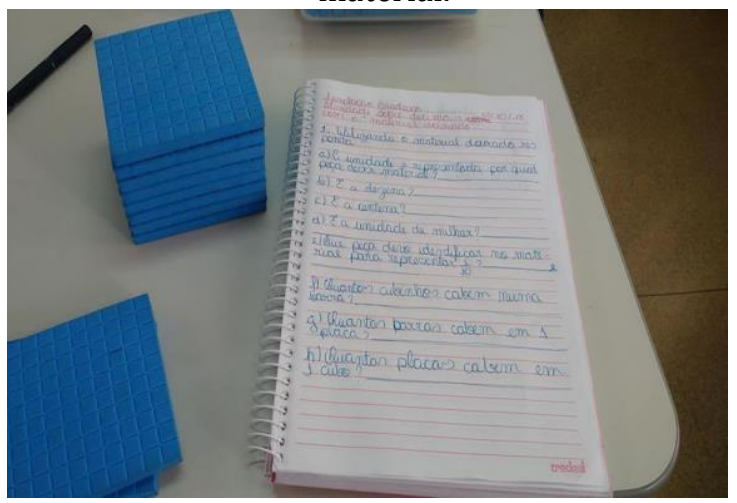

Fonte: Registros da Professora da Escola.

Foto 3 - Utilização do jogo Mina dos números decimais no laboratório de informática da Escola.

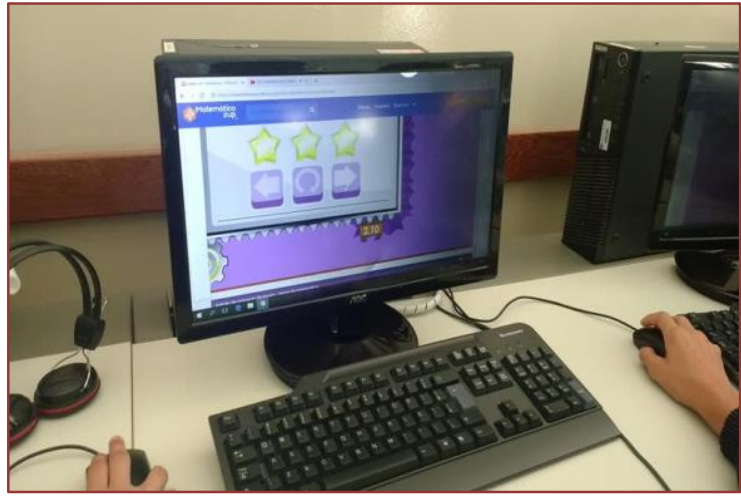

\section{DESCRIÇÃO E ANÁLISE DOS DADOS}

Essas atividades formam feitas com 39 alunos do 6oano, os quais dividimos a turma em 7 grupos de 5 componentes e um grupo de 4 componentes. Cada grupo selecionou o que mais lhe chamou a atenção na atividade em sala com a manipulação do material dourado, e com o uso do celular, produziu um vídeo, onde explicaram o que tinham aprendido nas aulas anteriores. Foram produzidos 8 vídeos no total, dos quais registramos os depoimentos e selecionamos dois para mencionar neste artigo. Nas fotos 4 e 5 , os registros dos vídeos construídos por dois grupos, sobre a representação e a comparação de números decimais. 


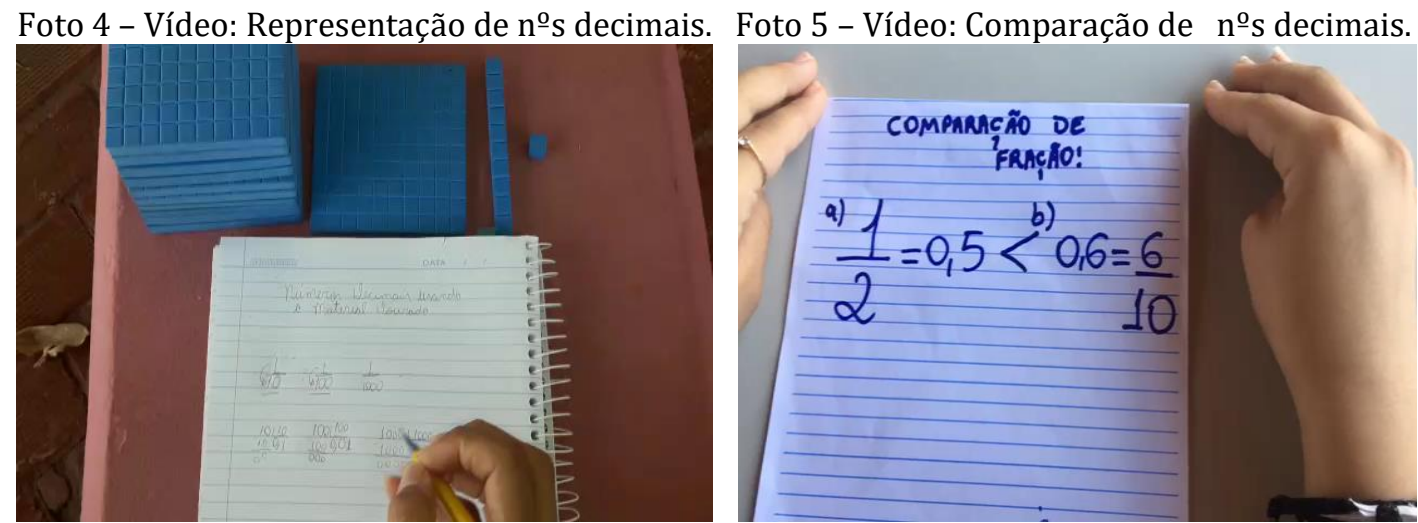

No primeiro vídeo, mostrado na foto 4, temos um dos alunos, que chamaremos de A1, analisando as relações entre as peças do material dourado e representando essas quantidades em forma de frações e números decimais. Ao questioná-lo sobre o que achou da experiência com a manipulação do material em sala, o A1 respondeu: "achei mais fácil responder as perguntas pegando as peças do material e comparando com os números". Já na foto 5 , a aluna, que chamaremos de A2, utilizou o material para fazer comparações entre valores decimais. Questionei com a mesma sobre o que a produção do vídeo a ajudou na compreensão da comparação de decimais. A aluna A2 respondeu: "ao fazer o vídeo precisei estudar mais para explicar para as outras pessoas e entendi melhor".

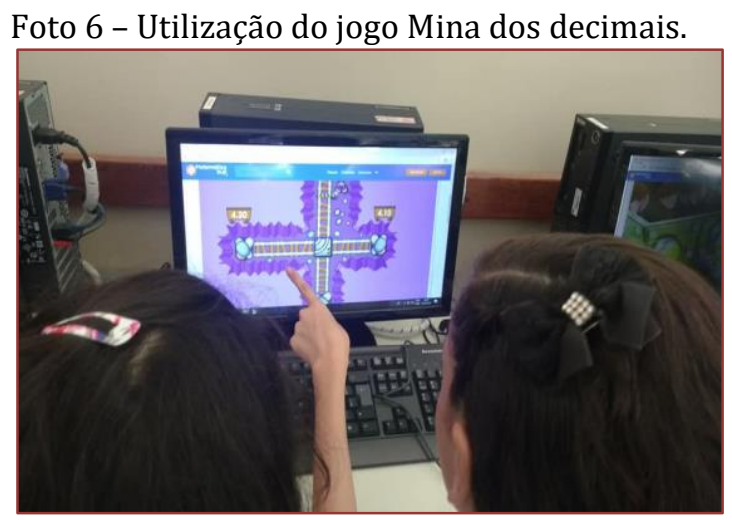

Após a utilização e discussão do jogo, onde trabalhei a adição e subtração de decimais, perguntei para uma aluna, que chamaremos de A3, de que forma o jogo tinha ajudado na resolução dos cálculos. A aluna A3 respondeu: "com o jogo é mais divertido e aprendi a fazer o cálculo mais rápido. Vi também que nos resultados a vírgula ficava no mesmo lugar".

Diante dos relatos dos alunos, podemos destacar que a união do material dourado manipulável e das tecnologias utilizadas tornou as aulas mais atraentes e desafiadoras. Assim, corroborando com Moran (2007):

As tecnologias são pontes que abrem a sala de aula para o mundo, que representam, medeiam o nosso conhecimento do mundo. São diferentes formas de representação da realidade, de forma mais abstrata ou concreta, mais estática ou dinâmica, mais linear ou paralela, mais todas elas, combinadas, integradas, possibilitam uma melhor compreensão da realidade e o desenvolvimento de todas as possibilidades do educando, dos diferentes tipos de inteligência, habilidades e atitudes (MORAN, 2007, p.164). 


\section{CONSIDERAÇÕES FINAIS}

Após a realização das atividades com os alunos, constatei a importância de trabalhar os números decimais tanto de forma concreta, usando o material dourado manipulável, quanto usando a tecnologia para o registro das análises com o uso do celular e o jogo como motivação e desafio na resolução dos cálculos, não desprezando totalmente a aula expositiva.

Com o avanço da tecnologia, mudou também a forma de pensar, tornando tudo mais dinâmico. Não temos que competir com a tecnologia, mas sim, tê-la como aliada em nossas aulas, tornando-as prazerosas para o aluno. 0 professor precisa ser um investigador de sua própria prática, procurando sempre melhorar através do que não deu certo, estudando novas estratégias de ensino. Esses tipos de atividade estreitam o dialogo entre professor e aluno, no qual o professor será apenas um mediador do conhecimento. A união do material manipulável e dos recursos tecnológicos ajudaram os alunos a compreender melhor o conteúdo, além de motivá-los na resolução dos cálculos.

\section{AGRADECIMENTOS}

A professora Salete Maria Chalub Bandeira, pelas contribuições, discussões e reflexões frente ao tema do artigo, através da disciplina de Tecnologias e Materiais Curriculares para o Ensino de Matemática que faz parte da Estrutura Curricular do Mestrado Profissional em Ensino de Ciências e Matemática da Universidade Federal do Acre. Aos alunos do 6o ano da Escola de Educação Básica e Profissional Fundação Bradesco por aceitarem o desafio de aprender com os novos recursos tecnológicos.

\section{REFERÊNCIAS}

[1] Anacleto, A.; Michel. S. A.; Otto, J. Cinema e Home Vídeo Etertaintnment: o mercado da magia e a magia do mercado. Np. 2007

[2] Ausubel, D. P.; Novak, J. D.; Hanesian, H. Psicologia Educativa: un punto de vista cognoscitivo. México, Trillas, 1983.

[3] Cortês, H. A importância da tecnologia na formação de professores. Revista Mundo Jovem. Porto Alegre, n. 394, p.18, mar de 2009.

[4] Daltoé, Karen, Strelow, Sueli. Trabalhando com Material Dourado e Blocos Lógicos nas Séries Iniciais. Disponível em: <http://www.cp.uttpr.edu.br/armando/adm/arquivos/pos/material_dourado.pdf>. Acesso em: 08 dez. 2018.

[5] Freire, Paulo. Pedagogia da Indignação: cartas pedagógicas e outros escritos. São Paulo: Unesp, 2000.

[6] Kenski, Vani Moreira. Educação e tecnologia - 2ª Edição. Local Campinas, Papirus, 2007.

[7] Lorenzato, Sérgio (org). O Laboratório de ensino de matemática na formação de professores. Campinas: Autores Associados, 2006.

[8] Machado, V. M. S.; Bandeira, S. M. C. 0 uso do material dourado manipulável e da tecnologia no ensino dos números decimais para alunos do 6oano. In: Encontro Nacional de Educação Matemática, 13, 2019, Cuiabá. Anais [...]. Cuiabá-MT: Arena Pantanal. ISSN 2178-034X. p. 1-10.

[9] Moran, J. M. Desafios na comunicação pessoal. Gerenciamento integrado da comunicação pessoal, social, e tecnológica. $3^{a}$ Ed. São Paulo: Paulinas, 2008.

[10] Oliveira, Sandra Alves de. O lúdico como motivação nas aulas de Matemática e Estatística, professora no Departamento de Educação Guanambi, BA, Uneb. Endereço eletrônico: soliveira@hotmail.com Artigo publicado na edição no 337, jornal Mundo Jovem, junho de 2007, p.5.

[11] Santos, J. C. F. dos. Aprendizagem significativa e sua implementação em sala de aula. Brasília. Editora Universidade de Brasília, 2006. 


\section{Capítulo 5}

\section{O uso de jogos com cartas no ensino da Matemática}

\section{Adriano Araquem Baia Menezes \\ Kédna Syuianne Quintas Melo \\ Mario Tanaka Filho}

Resumo: 0 uso de jogos no ensino da matemática é uma das tendências pedagógicas que pode ser utilizada para facilitar e tornar o processo de ensino-aprendizagem mais agradável, dinâmico, chamando a atenção dos alunos com o lúdico, bem como fazer com que o aluno tenha uma participação mais forte neste processo. Este artigo trata-se de uma pesquisa descritiva, caracterizada principalmente pela descrição, registro, análise e interpretação de fenômenos, cujo objetivo é evidenciar quatro jogos com baralhos (baralho tradicional de 52 cartas, com 4 naipes), identificando alguns tópicos de matemática bem como as habilidades e competências envolvidas e apresentar sugestões de como estes jogos podem facilitar o processo de ensino-aprendizagem. Mostram-se ainda os parâmetros legais sobre o uso de jogos e atividades lúdicas em sala de aula, bem como as concepções de Piaget e Vygotsky a respeito desta temática.

Palavras-chave: Ensino de Matemática; jogos com cartas; Poke; Pif-Paf 


\section{INTRODUÇÃO}

O ensino da matemática no Brasil iniciou com a chegada dos Jesuítas, tendo alicerce nos conhecimentos práticos, enfatizando a escrita dos números e as operações algébricas. Anos mais tarde com a criação de um colégio das artes no Rio de Janeiro começou a ser ensinado tópicos mais avançados como geometria elementar. As aulas eram expositivas com modelo de aprendizagem baseado em técnicas de memorização e repetição (Silva, 2014).

A maneira como a matemática era interpretada nos séculos passados, não se distingue muito da maneira como ela é vista atualmente. A ideação de uma ciência que atua isoladamente das demais, que pouco tem relação com o cotidiano do aluno, tendo o seu estudo útil apenas para a realização de uma avaliação no final, continua. (Andrade, 2014).

Nas escolas, facilmente são encontrados alunos que apresentam resistência ou oposição quanto ao aprendizado deste componente curricular. Dentre os fatores acerca dessa dificuldade, podemos destacar: ensino inapropriado, falta de ligação dos problemas propostos com a realidade dos alunos, falta de aptidão e também a interação alunos- professor (Silva, 2014).

O baixo rendimento dos alunos e as dificuldades no que diz respeito esse componente curricular preocupa educadores e os faz buscar maneiras alternativas acerca do ensino de matemática. Uma alternativa que tem sido utilizada para mudar o panorama atual, tem sido o uso de jogos pedagógicos. Isso torna o ambiente mais dinâmico e favorece na compreensão e interpretação dos assuntos (Rengel et al, 2012). 0 ensino através de jogos proporciona o desenvolvimento de habilidades que estão intimamente relacionadas com o raciocínio lógico, além de ser instrumento de motivação no que tange a participação dos discentes nas aulas, tornando-se uma grande ferramenta para os docentes no processo de ensino e aprendizagem da matemática (Ferreira et al, 2013).

Tendo isso em vista, este artigo tem por objetivo propor o uso de jogos com cartas como ferramenta facilitadora no ensino de matemática, pois este material permite uma abordagem lúdica e agradável, além de possibilitar uma grande dinamicidade nas abordagens, permitindo haver variações quanto a regra de seus jogos bem como a criação de novos jogos. Uma vez que, a utilização dos jogos de cartas, possibilita uma relação entre o jogo aplicado com o assunto abordado em sala de aula. (Rengel et al, 2012).

Trata-se de uma pesquisa descritiva, que segundo Marconi e Lakatos (2011), p.6, dizem que a pesquisa descritiva "delineia o que é", tendo como característica a descrição, registro, análise e interpretação de fenômenos atuais, tendo enfoque em seu o seu funcionamento no presente. Segundo Gil (2011), as pesquisas descritivas são habitualmente utilizadas em pesquisas de cunho social com enfoque na atuação prática e são comumente requeridos por instituições educacionais, comerciais e por partidos políticos.

\section{FUNDAMENTAÇÃO TEÓRICA}

A aversão dos alunos a matemática está muito ligada à maneira como ela é apresentada, sendo cada vez mais notório que ela se tornou uma disciplina que assusta muitos discentes. Devido a isso, os docentes devem adotar metodologias de ensino que sejam adequadas e que atendam a realidade de cada grupo de alunos. Tal metodologia também deve envolver os aspectos abordados nos Parâmetros Curriculares Nacionais - PCN.

Os PCNs são documentos que servem como orientação para o ensino fundamental e médio, buscando auxiliar os docentes nas suas aulas e direcionar um caminho para a organização curricular nos últimos anos da educação básica (Pinto, 2017). As orientações dos PCNs colaboram para o desenvolvimento de pensamentos e de atitudes, podendo possibilitar nos alunos a capacidade de resolução de problemas através da prática de investigação, desencadeando neles o medo de enfrentar e resolver situações novas.

As metodologias de ensino, segundo os aspectos dos PCNs, envolvem o uso de artifícios para auxiliar os professores em sala de aula, como a história da matemática, resolução de problemas, o uso de tecnologias, utilização de materiais lúdicos e concretos, utilização dos jogos e a contextualização de conteúdos que facilitem o processo de aprendizagem dos alunos assim como o trabalho do professor. 0 presente trabalho possui como foco principal a utilização do jogo como melhoria no processo de ensino e aprendizagem da matemática.

A utilização do jogo como metodologia de ensino, segundo os PCNs:

Constituem uma forma interessante de propor problemas, pois permitem que estes sejam apresentados de modo atrativo e favorecem a criatividade na elaboração de estratégias de resolução e busca de soluções. Propiciam a simulação de situaçõesproblema que exigem soluções vivas e imediatas, o que estimula o planejamento das ações. (Brasil, 1998, p.46)

Como observado, o jogo é visto como uma alternativa para a resolução de problemas, e passa a ser representado por uma situação problema delimitado por regras, onde o participante tenta de qualquer forma traçar estratégias para resolver o problema, ou seja, para vencer o jogo. Com isso, segundo Baumgartel (2016, p.5), os jogos "são considerados uma maneira de possibilitar a elaboração de estratégias e o planejamento de ações, considerando as suas consequências em relação às próximas etapas do mesmo". Autores como Piaget e Vygotsky, apresentam contribuições para a utilização do jogo como metodologia de ensino e para o desenvolvimento intelectual do aluno. 
Piaget realizou profundos estudos sobre a utilização dos jogos, acreditava que a concentração voltada somente para o jogo não era eficiente e interessante, pois o jogador se preocupava somente com resultado final dessa prática. Tendo em vista esses argumentos, Piaget propôs uma abordagem genética sobre a utilização do mesmo, compreendendo que essa prática é uma atividade essencial para o desenvolvimento da criança, baseando seus argumentos nos seus estudos sobre a evolução das suasestruturas lógico-matemáticas (Santos, 2008). Piaget identificou na sua investigação três tipos de jogos: jogo de exercício, jogo simbólico e jogo de regras (Santos, 2008).

Para Piaget os primeiros jogos a surgir na vida das crianças, segundo Baranita (2008), são os jogos dos exercícios, onde as regras e os símbolos ainda não existem. Estes jogos têm como objetivo principal a constante repetição de movimentos, sendo realizados pelo mero prazer que a criança tem ao desenvolvê-lo, como andar, correr, sacudir os braços e entre outros. Segundo Piaget, os jogos de exercícios podem ainda ser divididos em: jogos de pensamento e os jogos de exercícios sensório-motores.

Nos jogos simbólicos, a criança passa a criar representações para suas estruturas lúdicas, começando a distinguir o imaginário do real, passando a atribuir um significado ao símbolo, de uma forma que lhe dá mais prazer. Essa fase costuma dar seus primeiros indícios de 2 aos 6 anos de idade.

Na fase dos jogos de regras, a criança só passará a achar uma certa atividade interessante a partir do momento em que esta atividade possuir regras, pois, isso faz com que a criança se concentre mais na atividade que está sendo realizada, além de regularizar seu comportamento. Nesta fase, o seu prazer está nos resultados obtidos através da utilização das regras preestabelecidas, ocorrendo na faixa etária de 7 aos 11 anos de idade. No entanto, segundo Baranita (2008, p. 39), "o jogo de regras só aparece quando a criança deixa a fase egocêntrica e passa a ser social, desenvolvendo os relacionamentos sócio afetivo que se prolongam por toda a vida". Ao realizar essa análise sobre a utilização dos jogos, Piaget percebeu que tal ferramenta auxilia no desenvolvimento intelectual, moral e social da criança, sendo indispensável das práticas educativas.

Já Vygotsky realizou uma relação entre o desenvolvimento e a aprendizagem, defendendo que a utilização dos jogos incentiva a autoconfiança e a curiosidade. Vygotsky utilizou o conceito de Zona de Desenvolvimento Proximal (ZDP), que fala sobre a distância entre o desenvolvimento real, que é aquele onde a criança realiza as atividades sozinhas, e o desenvolvimento potencial, que é aquele onde a criança necessita de ajuda para realização de determinadas atividades. Tal fase está frequentemente sofrendo mudanças, pois a criança passa rapidamente a fazer sozinha atividades que antes só eram realizadas com o auxílio de outras pessoas.

Tendo isso em vista, observa-se a importância que os jogos possuem para o desenvolvimento da criança e para o processo de ensino da matemática. Diante disso, temos o uso de jogos com baralho como alternativa para o ensino da matemática.

Para Martins et al (2015) o baralho é um recurso a ser utilizado de maneira favorável ao processo de ensino e aprendizagem. A respeito disto, Regel et. a.l (2012) diz que "é possível utilizar esse recurso de forma a contribuir para a aprendizagem da matemática de forma lúdica e agradável”. Isso se dá também pela dinamicidade que os baralhos proporcionam para se criar novas regras a jogos já existentes e também para a criação de novos jogos.

\section{COMPETÊNCIAS E HABILIDADE DESENVOLVIDAS EM JOGOS COM BARALHOS}

Segundo os PCNs, o ensino da matemática deve fazer com que o aluno consiga aplicar seu conhecimento matemático em diversas situações (interpretação da ciência, atividades tecnológicas, atividades cotidianas), desenvolver capacidades de raciocínio bem como a resolução de problemas. Além disso, deve ajudar os discentes a formular hipóteses e também prever resultados, bem como ser capaz de selecionar estratégias para a resolução de problemas. Nos PCNs, ainda diz que a matemática deve ajudar os estudantes a "interpretar e criticar resultados numa situação concreta", "distinguir e utilizar raciocínios dedutivos e indutivos".

As aplicações da Matemática podem ser visualizadas em diversas atividades do cotidiano, que, com o passar do tempo, tornaram-se bastante complexas. Tais atividades

podem ser realizadas, por exemplo, através da análise e descrição de números de dados, aplicabilidade das noções de combinatória e probabilidade a fenômenos naturais e entre outros. Uma vez que, tais aplicações, podem ser vistas tanto nas Ciências Humanas quanto nas Ciências da Natureza. "Isto mostra como será importante uma cuidadosa abordagem dos conteúdos de contagem, estatística e probabilidade no Ensino Médio, ampliando a interface entre o aprendizado da Matemática e das demais ciências e áreas (Brasil, 1998, pp.44-45)".

As principais aplicações de jogos com cartas estão relacionadas aos princípios de contagem e probabilidade, e segundo o PCN+, os princípios de contagem devem ajudar a conseguir obter e escolher formas pertinentes de organizar números e também informações de maneira a facilitar cálculos em situações reais, da mesma maneira que deve detectar constâncias "para estabelecer regras e propriedades em processos nos quais se fazem necessários os processos de contagem". 
A compreensão da ideia de probabilidade aplicada a fenômenos naturais, sociais, tecnológicos ou científicos, como forma de prever resultados, assim como reconhecer em outros campos de estudos, problemas que estejam relacionados com probabilidade e estatística, são alguns dos pontos que os PCN+ vem abordar em relação ao aprendizado dos alunos com a probabilidade. (Brasil, 2007, p.127-128).

O ensino da análise combinatória, princípio da contagem, estatística e probabilidade, têm por finalidade fazer com que os alunos compreendam que, a maioria dos acontecimentos que fazem parte do seu cotidiano ocorre de maneira aleatória, e que pode ser realizado um estudo para prever alguns resultados desses acontecimentos. De forma análoga podemos falar do uso das cartas, onde é possível prever grande parte dos resultados de alguns jogos, fazendo uso desses assuntos. As cartas, nesse sentido, tornam- se uma ferramenta facilitadora para absorção e entendimento dos conteúdos aqui supracitados.

Segundo as competências dos PCNs do ensino fundamental, em relação às quatro operações, os alunos devem saber alguns significados das operações básicas (soma, subtração, divisão e multiplicação) na resolução de problemas, além de ter a capacidade de elaborar seus próprios significados. É também importante realizar uma reflexão das atividades repassadas, para que tal significado seja ampliado. Tendo em vista isso, o jogo com cartas possibilita que o aluno consiga associar os conceitos e significados das quatro operações com atividades do seu cotidiano, que tem por objetivo facilitar o processo de ensino e aprendizagem.

Nesse sentido, serão mostrados a seguir alguns jogos com cartas que podem contribuir no ensino da matemática e no desenvolvimento que esta deve proporcionar aos alunos.

\section{DESCRIÇÃO E ANÁLISE DOS DADOS}

\subsection{POKER E PIF-PAF}

O Poker e o Pif-Paf são dois jogos muito populares e que possuem princípios semelhantes, mas se diferem quanto as "mãos" a serem formadas e a quantidade de cartas usadas nas dinâmicas de jogo. Mas ambos proporcionam análises matemáticas semelhantes e que podem ser utilizadas em sala de aula.

O Poker é o jogo de cartas mais popular no mundo, utiliza um baralho padrão de 52 cartas e pode ser jogado com 2 ou mais pessoas, geralmente praticado com apostas. Possui muitas modalidades como por exemplo: Texas Hold'em, Omaha, Stud, Draw Poker e Razz. Essas modalidades podem se diferenciar na quantidade de cartas recebidas por cada jogador, pelo modo de jogo ou pelas apostas. A modalidade aqui apresentada será aquela de maior popularidade, a modalidade Texas Hold'em, nela vence o jogador que for até o final das rodadas e tiver a melhor mão de 5 cartas. Bellicanta e Ehlert (2015), abrange as regras do poker, às hierarquias das mãos bem como a dinâmica do esporte.

Uma vez aprendida as regras do jogo, sabe-se que cada jogador receberá cartas aleatórias, assim, o conhecimento acerca de probabilidade é crucial para vencer o jogo, pois ele precisa analisar suas chances, possibilidade e decidir se deve continuar, desistir ou apostar.

Este jogo, segundo Thebas et al (2014) é uma ação prática das noções de combinatória e probabilidade, podendo ser usado no entendimento os conceitos e aplicações. Para o uso deste, os alunos já deverão ter estudado previamente as matérias e já ter ideia de "como se faz a análise combinatória e como se calcula a probabilidade de um evento qualquer acontecer dentro de um espaço amostral".

Segundo Bellicanta e Ehlert (2015) o jogo de Poker é um mecanismo que pode ajudar o educador a seguir as orientações dos PCNs, onde nele, podem-se identificar dados do jogo, suas relações em problemas e situações que abranjam raciocínio combinatório (processos de contagem), reconhecimento da aleatoriedade do jogo e eventos que podem ocorrer nele percebendo o uso da probabilidade como uma maneira de tentar prever resultados. A partir dessas percepções no poker é possível expandir as ideias para aplicar as noções nas diversas áreas do conhecimento e no cotidiano.

Neste jogo, trabalha-se com o baralho completo (espaço amostral), calculando primeiramente quais as possíveis combinações da primeira distribuição de cartas (pre- flop). Assim, com ajuda da análise combinatória, eles descobrirão que com o espaço amostral de 52 cartas, existem 1326 combinações de cartas. Após receber suas cartas, o aluno analisará as chances de melhorar sua "mão", decidindo se permanece ou não no jogo, fazendo isso também para as etapas consecutivas (flop ${ }^{9}$, turn ${ }^{10}$ e river ${ }^{11}$ ).

${ }^{9}$ As três primeiras cartas comunitárias (cartas dispostas na mesa usadas para compor as mãos dos jogadores) do jogo de poker.

10 Quarta carta comunitária do jogo de poker.

${ }^{11}$ Quinta carta comunitária do jogo de poker. 
Outra situação inicial a ser analisada é quais as chances dos jogadores obterem uma determinada "mão", por exemplo, um par de ases, dessa maneira, o jogador precisará 2 cartas de um total de 4 , ou seja $C 4,2=6$ possibilidades, porém, no baralho são 13 possibilidades possíveis, logo $6 \times 13=78$ possibilidades diferentes na primeira distribuição de cartas, onde a probabilidade que esse evento ocorra é aproximadamente 5,88\%. Dessa mesma man eira é possível calcular as chances e as possibilidades de qualquer "mão" ocorrer. Nesse cenário, cabe também avaliar as chances de o par de ases evoluir para uma trinca ou para uma quadra.

Em jogo, o aluno também deverá fazer análises críticas da situação, tendo em mente que por melhor que seja a sua "mão", há ainda a chance de outro jogador ter uma "mão" ainda melhor, assim ele deve "fazer" a leitura de seu oponente agregada com os cálculos para suas tomadas de decisões.

Já o Pif-Paf é um jogo de cartas que utiliza dois baralhos padrões de 52 cartas cada, tendo assim cartas duplicadas e pode ser ou não usadas os coringas. 0 jogador recebe nove cartas de maneira aleatória e vence aquele que primeiro três trios, onde esses trios devem ser cartas em sequência e de mesmo naipe, ou por 3 cartas de mesmo valor porém naipe diferente. Assim, fica a cargo dos participantes se atentarem as jogadas dos adversários, estimando o número de cartas que estão em jogo para compor a mão desejada (Seara, 2011). Às demais regras deste jogo são expostas no site www.megajogos.com.br.

Assim como no poker, esse jogo também pode ser utilizado como ferramenta de aplicação dos conceitos matemáticos. É um jogo de funcionamento simples, porém de enorme potencial a ajudar no desenvolvimento do raciocínio, capacidade de previsão e em análises combinatórias, tais como orienta os PCNs e o PCN +.

Aqui também é possível fazer análises semelhantes às do poker, porém com um espaço amostral de 104 cartas ou 108 casos as cartas coringas estejam em jogo. Algumas análises básicas que podem ser feitas são por exemplo: as possíveis combinações podem ser obtidas na primeira distribuição de cartas, a probabilidade de uma carta "comprada" do monte por um determinado jogador ser a que ele precisa para formar uma das trincas.

Análises que podem ser feitas pelos alunos são quais as chances de o jogador já vir com uma trinca pronta, ou duas, ou até mesmo com 3 trincas e ganhar a partida, todavia, essa última possui chances estatísticas bem baixas de acontecer, e essas são conclusões que os próprios alunos devem conseguir chegar por meio do conhecimento matemático. 0 aluno pode investigar também quais as chances de conseguir formar uma trinca de Ases, ou Damas, e Reis (todos de naipes diferentes) até mesmo de conseguir formar três trincas com esses valores e ganhar o jogo. São inúmeras as possibilidades e análises a serem feias, cabe ao professor estimular os alunos a pensarem quais podem ser feitas e como podem ser feitas.

Esses dois jogos, usados de maneira correta, são grandes ferramentas, como já foi citado, para o aprendizado de conteúdos como contagem, sucessores, antecessores, estimativa, combinação e muitos outros que o professor consiga idealizar. Conforme as ideias de Piaget em que cada etapa de desenvolvimento da criança está ligada a um tipo de jogo, estes podem se caracterizar como jogos de regras, onde chama a atenção da criança devido às suas várias regras e dinâmicas de jogo. São essas regras que estimulam a concentração e o comportamento, onde o prazer se alcança justamente no ato de seguir as regras. Isso pode ser tirado proveito atribuindo como regras o uso de cálculos probabilísticos e combinatórios, bem como o estímulo de competição inerente ao uso de jogos.

Assim o uso destes jogos pode ajudar em processos de desenvolvimento social, moral, intelectual e cognitivo, conforme as ideias de Vygotsky (1984) onde ele acredita também que pelos jogos a criança consegue estabelecer e usar conhecimentos adquiridos neles na vida real. Assim o seu uso voltado a assuntos matemáticos atua como facilitador do processo de ensino e aprendizagem.

\subsection{JOGO DAS QUATRO OPERAÇÕES E JOGO DO PRINCÍPIO MULTIPLICATIVO}

O jogo das quatro operações e o jogo do princípio multiplicativo são jogos que trabalham as quatro operações básicas da matemática (soma, subtração, divisão e multiplicação). Embora tais operações sejam vistas como um assunto fácil no ensino fundamental, elas podem vir a confundir o aluno no momento em que são trabalhadas em conjunto. Valendo ressaltar que nos primeiros anos da escola é esperada a aprendizagem desse conteúdo pelos discentes, todavia, isso nem sempre acontece, fazendo com que esse déficit seja prolongado para os próximos anos.

Nesse sentido o jogo das quatro operações e o jogo multiplicativo tem o objetivo de ser um instrumento facilitador para o processo de ensino e aprendizagem da matemática no ensino fundamental, visando fazer com que os alunos tenham mais domínio sobre as quatro operações, e os auxiliando a resolverem problemas e questões do seu dia-a-dia por meio de novos métodos embasados nos conteúdos aqui trabalhados.

Para o jogo das quatro operações se utiliza um baralho de 52 cartas, podendo ser jogado por até quatro jogadores. Em seguida, as cartas dos baralhos são embaralhadas e distribuídas entre os 4 participantes, posteriormente um número é determinado. 0 objetivo do jogo consiste em obter o número determinado através de duas cartas, utilizando para isso as operações aritméticas. Supõe-se, por exemplo, que o número determinado seja o 9, cada jogador poderá virar duas de suas cartas e analisar se elas formam o número 9 através de uma das quatro operações. 
Às demais regras deste jogo podem ser verificadas em Medeiros (2013).

Já o jogo multiplicativo pode ser considerado uma variação do jogo das quatro operações. 0 intuito desse jogo é trabalhar o aprendizado da tabuada, capacidade analítica, formulação de hipótese, resolução de problemas como a tomada de decisões para este objetivo.

Para a realização desse jogo é necessário formar grupos de quatro pessoas, utilizando apenas as cartas com numerações de 2 a 9 de um baralho. Em seguida será escolhido um integrante de cada grupo que escolherá, ao acaso, 4 cartas sem permitir que nenhum outro integrante as veja. 0 objetivo do jogo consiste em tentar adivinhar quais são as cartas realizando perguntas envolvendo a multiplicação, por exemplo: "você tem duas cartas que o produto entre elas é (diz um valor)”. Às demais regras deste jogo podem ser verificadas em Mourad (2014).

Estes jogos também funcionam como um mecanismo facilitador para que o professor siga as orientações estabelecidas pelos PCNs, onde pode ser observada a resolução de problemas que consolidam os significados das quatro operações fundamentais, além da reflexão sobre como realizar cálculos de modo que o significado dos números e das operações se amplie. Uma vez que estes dois jogos também possibilitam o estímulo da criatividade e do raciocínio, fazendo com que o aluno crie novos métodos para resolução de problemas. Tendo em vista que também é previsto que o aluno consiga produzir estratégias pessoais de solução, possuindo justificativas para a realização de tais processos em relação ao problema proposto. Sendo fácil perceber a íntima relação existente entre o jogo das quatro operações e o jogo multiplicativo com as competências pré-estabelecidas pelos PCNs.

A utilização desses dois jogos, como já foi citado, servem como instrumentos facilitadores para o processo de ensino e aprendizagem da matemática. Uma vez que, de acordo com as ideias de Vygotsky (1984) ao estudar o conceito de Zona de Desenvolvimento Proximal (ZDP), o jogo estimula a autoconfiança e a curiosidade que faz com que o aluno esteja sempre motivado a concluir suas atividades. Atividades essas que são realizadas com o auxílio do professor, mas que, com o passar do tempo, passarão a ser realizadas pelos próprios alunos sem a necessidade de um auxílio.

\section{CONSIDERAÇÕES FINAIS}

Este trabalho objetivou mostrar alguns jogos com cartas que podem ser utilizados para estimular o interesse dos alunos acerca de assuntos ministrados em sala de aula.

Esses jogos ajudam na compreensão dos assuntos e também onde e como os estudantes podem a vir usar esses conhecimentos em situações reais.

Essas atividades diversificadas e lúdicas aos alunos intensificam o aprendizado destes, pois tornam o aprender dos conteúdos mais prazeroso, isso os faz participarem de maneira mais assídua das aulas. A prática de jogos com carta pode ser utilizada para diversos fins na área de ensino, desde assuntos mais simples como as operações básicas até o ensino de probabilidade, análise combinatória. Podemos afirmar também que o uso dessas atividades desenvolve o senso crítico dos alunos, bem como o raciocínio, criatividade, elaboração de estratégias e contribui para que o aluno consiga tomar decisões pautadas em pensamentos lógicos e análises matemáticas. Vale ressaltar que atividades com cartas deixam os alunos livres para modificar as suas regras conforme a sua realidade, bem como possibilita também a criação de novos jogos.

Aqui, diferentemente do método tradicional em que o educar é o detentor do saber e a aprendizagem se dá por meio da memorização e da repetição de exercícios, cabe ao professor conhecer a realidade de onde está atuando, estudar o uso dos recursos disponibilizados pela escola e também os que os próprios alunos possuem em suas casas. Esses recursos devem ser aproveitados ao máximo, caso contrário, o método tradicional estará apenas mascarado. Nesse sentido Rengel (2012) diz que "cabe ao educador avaliar se são pertinentes ou não em sua realidade e com seus educandos, realizar uma reflexão e aumentar o prazer pela disciplina. Precisamos de cidadãos que saibam decidir, encontrem as informações e saibam aplicá-las".

Para um professor de matemática, além de conhecer a sua área, ele precisa saber como direcionar os alunos ao entendimento dos assuntos, e ajudá-los a perceber que esses conhecimentos não se fazem isolados do mundo, eles podem ser aplicados no seu dia a dia.

Vygotsky (1984) diz que:

É na interação das atividades que envolvem simbologia e brinquedos que o educando aprende a agir numa esfera cognitiva. Na visão do autor a criança comporta-se de forma mais avançada do que nas atividades da vida real, tanto pela vivência na situação imaginária, quanto pela capacidade de subordinação às regras. (Vygotsky, 1984, p.27)

Portanto, a dinamização das aulas por meio de jogos e seu caráter lúdico, com devidos critérios pedagógico, aqui evidenciado com propostas de uso de cartas, são alternativas para estimular o aluno a aprender. Salienta-se à falta de trabalhos com a proposta do uso deste material (baralho francês), sendo este trabalho podendo servir de base para outros estudos vindouros. 


\section{REFERÊNCIAS}

[1] Andrade, Cíntia. O Ensino da Matemática para o Cotidiano. Universidade Federal Tecnológica do Paraná. Medianeira, 2014.

[2] Baumgartel, Priscila. O Uso de Jogos como Metodologia de Ensino da Matemática. Encontro Brasileiro de Estudantes de Pós-Graduação em Educação Matemática. Curitiba - PR, 2016.

[3] Baranita, Isabel. A Importância do Jogo no Desenvolvimento da Criança. Escola Superior de Educação Almeida Garret. Mestrado em Ciências da Educação. Lisboa, 2012. 2008

[4] Bellicanta, Leandro Sebben; Ehlert, Seldomar Jeske. A matemática no pôquer: Explorando problemas de probabilidade. Ciência e Natura, Santa Maria, v. 37 Ed. Especial Profmat, 2015, p.265-277

[5] Brasil. PCN - Parâmetros curriculares nacionais: Matemática/ Secretaria de Educação Fundamental Brasília: MEC/ SEF. 1998.

[6] Brasil.PCN+- Parâmetros curriculares nacionais: Matemática/ Secretaria de Educação Fundamental - Brasília: MEC/ SEF. 2007.

[7] Ferreira, Inês Farias, et al. Ludicidade e Matemática: Jogos no ensino funções. VII CIBEM - Congreso Iberoamericano de Educación Matemática, Montevideo. 2013

[8] Gil, Antônio Carlos. Métodos e Técnicas de Pesquisa Social. 6. ed. São Paulo: Atlas S.A., 2011.

[9] Marconi, Marina de Andrade; Lakatos, Eva Maria. Técnicas de Pesquisa: Planejamento e execução de pesquisa, Amostragens e técnicas de pesquisa, Elaboração, análise e interpretação de dados. 7. ed. São Paulo: Atlas S.A., 2011.

[10] Martins, Fabíola et al. Utilização De Jogo De Cartas No Ensino De Função Quadrática. II Conedu, Campina Grande - PB, 2015.

[11] Medeiros, Marylene. et al. Catálogo de Atividades e de Jogos com Cartas, Universidade dos Açores. Departamento de Ciências de Educação. Ponta Delgada,2013.

[12] Mourad, Halime Hammoud. Os desafios da escola Pública paranaense na perspectiva do professor PDE: Produções Didático-Pedagógicas. Secretaria de educação do Estado do Paraná. Universidade Estadual do Paraná (UNESPAR). Paranaguá. 2014

[13] Pinto, Antônio Henrique. A Base Nacional Comum Curricular e o Ensino de Matemática: flexibilização ou engessamento do currículo escolar. Bolema, vol.31, n.59, p.1045-1060. 2017

[14] Rengel, Ana Paula Vinoski. et al o uso de jogos de cartas como Estratégia para o ensino da matemática. I encontro PIBID. Matemática. EIEMAT - Escola de Inverno de Educação Matemática, 2012.

[15] Santos, Fernando. A Matemática e o Jogo: Influencia no Rendimento Escolar. Faculdade de Ciências e Tecnologia da Universidade Nova de Lisboa. Lisboa, 2008.

[16] Seara, Helenice Fernandes. Os Jogos como Facilitadores na Aprendizagem da Matemática. X Congresso Nacional de Educação - EDUCERE. Curitiba, 2011.

[17] Silva, Meiriane Vieira da. As dificuldades de aprendizagem da matemática e sua relação com a Matofobia. Universidade Estadual da Paraíba - UEPB. Princesa Isabel, 2014.

[18] Thebas, Thaciara da Silva. MAIA, Ismael José. Alves, Laurito Miranda. Pôker e suas probabilidades. Centro Universitário de Belo Horizonte, 2014.

[19] Vigotsky, L. S. A formação Social da Mente. São Paulo: Martins Fontes, 1984. 


\section{Capítulo 6}

\section{o que o quadrilátero contou para a circunferência no jardim?}

\section{Leonilson Calixto de Souza \\ Marcela Madanês Chavier}

Resumo: A geometria vem sendo ensinada no quadro negro ou através de livros didáticos, de forma teórica e desconexa da realidade, porém neste trabalho, relatamos uma experiência realizada com alunos do primeiro, segundo e terceiro anos do Ensino Médio na disciplina Eletiva da Escola Plena Deputado Bertoldo Freire localizada no Município de São José dos Quatro Marcos-MT, em que as noções básicas de geometria foram estudadas de forma prática e significativa através do uso da TIC's e da construção de um jardim, que além de transformar um espaço inutilizado em um ambiente agradável para os estudantes, serviu como um laboratório para o ensino e aprendizagem de matemática. A metodologia de pesquisa integrou observação participante e análise de objetos produzidos pelos estudantes. Concluiu-se que atividades práticas que expõem a matemática de forma concreta, apresenta-se como um objeto com significado para os alunos, proporcionando uma maior dedicação e efetiva compreensão do conteúdo estudado.

Palavras-chave: Geometria plana; Geometria espacial; Construção do jardim; Matemática na prática. 


\section{INTRODUÇÃO}

Segundo os autores Pavanello(2009) e Lorenzato(1995) o ensino de Geometria na educação básica tem sido negligenciado por um longo período nas aulas de Matemática. Algumas explicações para esse acontecimento referem-se à insegurança do professor que não possui domínio dos conteúdos que deveria estar ensinando - reflexo de uma formação deficiente-, à falta de tempo para cumprir toda a ementa planejada e dessa forma prioriza-se a álgebra, à disposição desses conteúdos no livro didático que normalmente é encontrado como temas finais, à ausência de uma abordagem que contemple a Álgebra e a Geometria de forma conjunta, além da ausência do uso de materiais manipuláveis e concretos que valorizem o aspecto dinâmico da Geometria e demonstre que a mesma faz parte do cotidiano.

Nota-se então que alguns autores têm se preocupado com o abandono do ensino da geometria nas salas de aula, o que é ruim, pois como destaca Freudenthal (apud FONSECA, 2001, p.497):

A Geometria é uma das melhores oportunidades que existem para aprender matematizar a realidade. É uma oportunidade de fazer descobertas como muitos exemplos mostrarão. Com certeza, os números são também um domínio aberto às investigações, e pode-se aprender a pensar através da realização de cálculos, mas as descobertas feitas pelos próprios olhos e mãos são mais surpreendentes e convincentes. Até que possa de algum modo ser dispensadas, as formas no espaço são um guia insubstituível para a pesquisa e a descoberta.

Neste sentido, Lima e Pitombeira (2010, p. 140) chamam atenção do professor para a necessidade da interação entre o abstrato e o concreto no estudo da geometria:

Professor, ao iniciar o estudo da geometria com seus alunos, procure valorizar a movimentação corporal, além de possibilitar o manuseio e a visualização de objetos do mundo físico. São também importantes as atividades que envolvam as representações gráficas - desenhos e imagens - desses objetos.

Nesta mesma linha, os Parâmetros Curriculares Nacionais propõem para o ensino da geometria, que o aluno desenvolva a compreensão do mundo em que vive, aprendendo a descrevê-lo, representá-lo e a se localizar nele, estimulando ainda o estudante a observar, perceber semelhanças e diferenças, a identificar regularidades, compreender conceitos métricos, e permitir o estabelecimento de conexões entre a Matemática e outras áreas do conhecimento.

Nesta concepção, Fonseca (2005, p. 54) alerta:

[...] Torna-se cada vez mais evidente a necessidade de contextualizar o conhecimento matemático a ser transmitido ou construído, não apenas inserindo-o numa situação-problema, ou numa abordagem dita "concreta", mas buscando suas origens, acompanhando sua evolução, explicitando sua finalidade ou seu papel na interpretação e na transformação da realidade com a qual o aluno se depara e /ou de suas formas de vê-la e participar dela.

Com vista aos problemas citados e a necessidade de se trabalhar a geometria de uma forma contextualizada com a realidade, propomos aos estudantes da eletiva, projetar e construir um jardim na escola como forma de resgatar um espaço inutilizado e usá-lo como laboratório de aprendizagens. Neste contexto, este trabalho objetivou dar condições para que os estudantes adquirissem conhecimentos geométricos relacionando os conceitos estudados em sala de aula com fatos da realidade, e para que resolvessem as situações problemas encontradas no planejamento e na construção do jardim, como também fizessem uso da tecnologia.

Assim, verificou-se que atividades práticas que expõem a matemática de forma concreta, se apresentam como um objeto com significado para os estudantes, desenvolvendo sua capacidade de reflexão e proporcionando uma maior dedicação e efetiva compreensão do conteúdo estudado. Observou-se ainda que os estudantes demonstraram maior cuidado com o ambiente escolar em especial com o jardim, uma vez que, foi construído por eles mesmos.

\section{PROCEDIMENTOS METODOLÓGICOS}

A eletiva é uma disciplina da base diversificada do currículo das escolas de tempo integral, em que os professores criam uma proposta e apresentam à comunidade escolar durante o feirão de vendas de eletivas e os alunos escolhem a que for de seu interesse para participar e desenvolver o projeto 
apresentado sob orientação dos professores responsáveis pela disciplina. Assim, o trabalho aqui relatado foi desenvolvido nas aulas da disciplina eletiva com uma turma composta por 30 alunos do primeiro, segundo e terceiro anos do Ensino Médio.

O projeto teve duração de um ano letivo, em duas etapas semestrais. Em que no primeiro semestre, após a escolha e medição do local, os estudantes foram divididos em 6 grupos para projetarem o jardim com uso do software sketchup e colaboração de um estudante de arquitetura. No segundo semestre, ainda separados em grupos, deu-se início a construção do jardim.

Para a obtenção de dados e análise, foram utilizados como instrumentos de pesquisa a observação participante e a análise dos objetos e documentos construídos pelos estudantes.

Em geral, no Ensino Médio, os alunos já tem um conhecimento prévio de geometria plana e espacial, e após um diagnóstico realizado de forma oral e com uso de figuras geométricas, averiguou-se que a maioria dos alunos reconheciam algumas figuras, mas não conheciam as propriedades que as definem, colocando-os assim no nível 1 da aprendizagem de geometria.

De acordo com os estudos desenvolvidos pelo casal holandês Dina e Peter Van Hiele (apud NASSER, 2010), há cinco níveis para a aprendizagem da geometria (visualização, análise, abstração, dedução e rigor), sendo que em uma mesma turma encontram-se vários níveis, pois cada estudante tem um desenvolvimento cognitivo. A partir dessa avaliação e seguindo as fases necessárias para organizar o ensino é que iniciamos o trabalho com os estudantes.

Nesta experiência, em alguns momentos, foram necessário retomar conteúdos e apresentar os problemas de formas diferentes, assim as etapas não aconteceram de forma estanque e ordenada.

No final do primeiro semestre houve a Culminância que é um momento de socialização do que foi realizado nas eletivas e para socialização dos resultados, os grupos expuseram seus projetos de jardim feitos no sketchup e houve votação da comunidade escolar, saindo ganhador o projeto intitulado Jardim Ravenna. Já no segundo semestre, na culminância foi apresentado o jardim pronto e os alunos fizeram um vídeo mostrando suas reflexões e informações a respeito da construção do jardim e destacando os pontos que consideraram mais significativos.

\section{RELATO DA EXPERIÊNCIA}

No primeiro momento, como mostra na figura1, foi realizado a escolha do local a ser construído o jardim, uma parte do pátio da escola que ficava sem utilização. Em seguida, os estudantes fizeram a limpeza do terreno, as medições, calcularam o perímetro, a área do local em $\mathrm{m}^{2}$, e considerando uma aresta de $10 \mathrm{~cm}$, que seria a altura do aterro necessário para plantar, calculou-se também quanto metros cúbicos de terra seriam necessários para o aterramento do local (volume $\mathrm{m}^{3}$ ).

Figura 1- 0 espaço inutilizado e sujo.

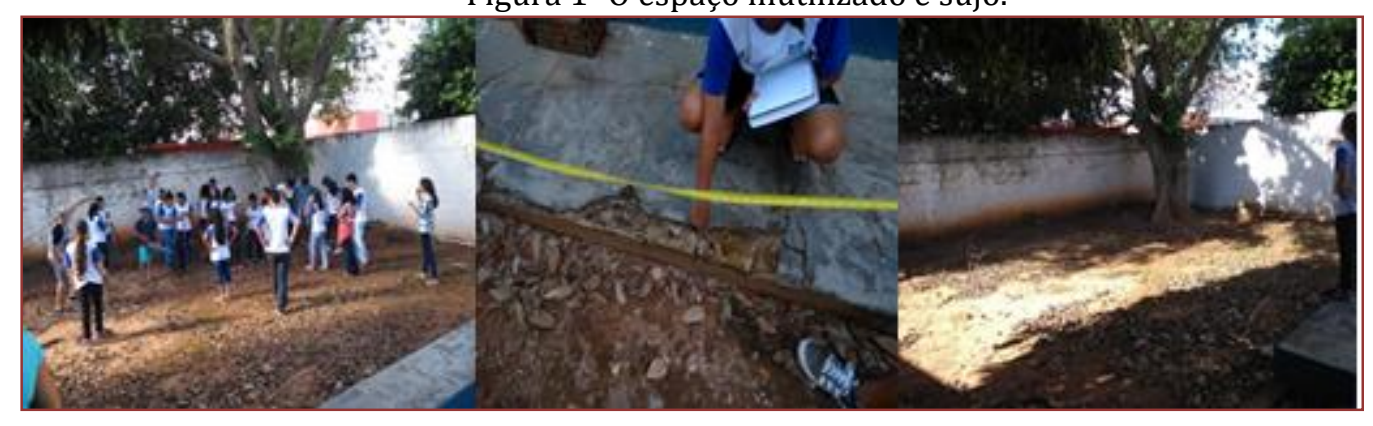

Após, os estudantes foram orientados a pesquisar quais tipos de plantas poderiam ser cultivadas naquele local, analisando o horário e a quantidade de incidência de sol no ambiente, e foi muito gratificante, porque os estudantes se empenharam na pesquisa e até descobriram o nome de uma árvore que já estava no local, e que posteriormente deu nome ao projeto ganhador, Jardim Ravena. 
Em seguida os 30 alunos foram divididos em 6 grupos, e assim foi proposto que projetassem um jardim iniciando pelo desenho de uma planta baixa utilizando os dados retirados do espaço escolhido, conforme mostra a figura 2 .

Figura 2 - Planta baixa.

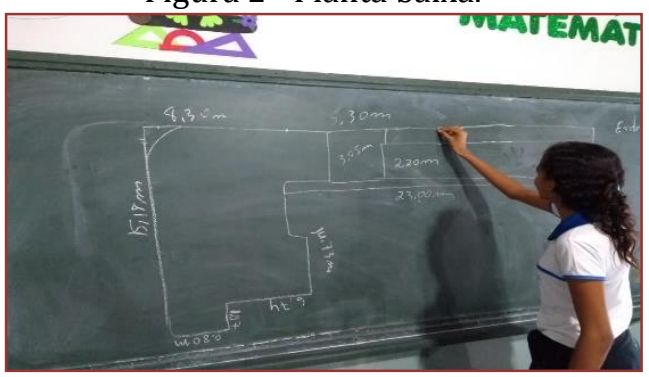

Com a planta baixa realizada, foi explicado para os estudantes que estávamos trabalhando em dois eixos no plano cartesiano, mas para um resultado mais próximo da realidade poderíamos trabalhar com plano cartesiano em 3 dimensões, e isso foi possível usando softwares profissionais de engenharia e arquitetura para projetar móveis e imóveis. Baseando-se em Almeida \& Assis (2013, p. 87) o professor deve:

[...] criar condições para o desenvolvimento da capacidade de buscar, interpretar e inter-relacionar informações advindas de distintas fontes, em especial das redes digitais, e transformá-las em conhecimentos, que podem ser representados por meio das múltiplas linguagens digitais para uso em situações da vida cotidiana e do trabalho. Assim, os projetos de inclusão e emancipação digital trazem embutidos três focos- cidadania, educação e profissionalização.

Visto isso, enxergamos na inserção das TIC's, a possibilidade de tornar o processo de aprendizagem dos conceitos matemáticos mais dinâmico, prazeroso e próximo à realidade dos estudantes.

Isto posto, apresentamos o software sketchup através de tutoriais e depois um aluno egresso da escola que na ocasião já era acadêmico do curso de arquitetura deu suporte aos alunos. Através do software foi possível trabalhar retas paralelas, perpendiculares, escala, área e perímetro. E assim cada grupo começou a pôr as ideias em prática e conseguiram produzir seus projetos. No fim do semestre cinco grupos expuseram seus projetos na culminância, como mostra a figura 3, e foram votados, tendo como ganhador o projeto intitulado Jardim Ravena. Mas para que todos os alunos fossem valorizados na construção do jardim pegou-se elementos dos demais projetos para complementar.

Figura 3 - Projeto dos estudantes feito no software sketchup.

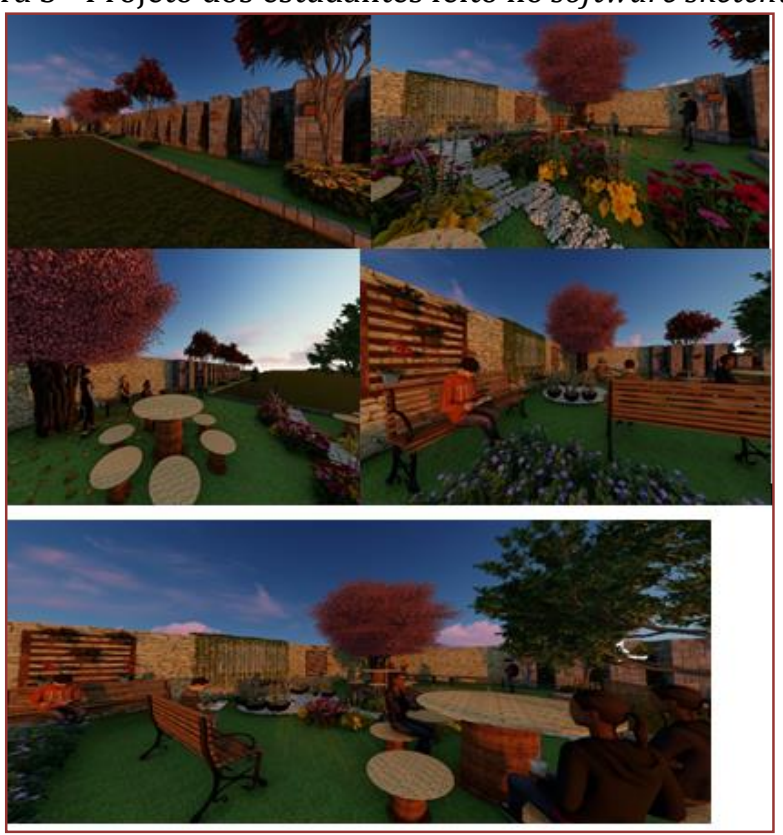


No segundo semestre foi o momento de pôr o projeto em prática, iniciando com o aterro do terreno, e com a pesquisa das plantas em mãos os estudantes se organizaram para adquirir plantas que eram adequadas ao espaço, para produzir as mudas.

Posteriormente os 30 alunos foram divididos em grupos para desenvolver alguns trabalhos, como confecção de vasos sustentáveis, de bancos, suporte(madeira) de vasos para paredes, suportes (madeira) com rodinhas para vasos, pergolado e execução do projeto.

Durante a construção do jardim os estudantes puderam observar e utilizar na prática alguns conceitos de disciplinas como biologia e matemática. De biologia no cultivo de planas e compostagem para adubo orgânico.

Na parte da matemática conseguiram entender que quando um pedreiro tira o nível de um terreno e estica uma linha essa linha está paralela com o nível do mar, também puderam relacionar que quando um pedreiro coloca uma parede ou um pilar no prumo isso significa que esse pilar ou parede está perpendicular com o piso, ou seja, forma um ângulo de $90^{\circ}$ com o plano do piso, do mesmo modo que quando um pedreiro diz que duas paredes estão no esquadro uma em relação a outra, isso significa que o ângulo formado por essas paredes é de $90^{\circ}$ e elas são perpendiculares. Outras fotos abaixo alunos e professores trabalhando na construção do jardim onde os alunos puderam trabalhar mais alguns conceitos de geometria vendo sua aplicação prática, durante a construção do jardim os estudantes calcularam comprimento da circunferência, áreas volumes, retas perpendiculares, ângulo e teorema de Pitágoras. Veja a figura 4 do jardim durante o processo de construção.

Figura 4 - Limpeza e construção do Jardim Ravena.

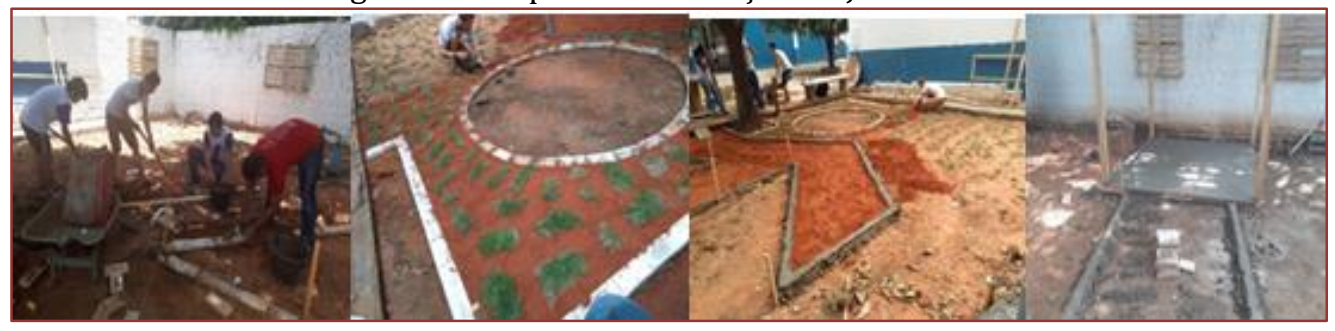

A figura 5 mostra os estudantes preparando dois carreteis que eram utilizados para enrolar fio, esses carreteis se tornaram mesas para serem utilizadas no jardim. Mais uma vez utilizaram-se da matemática ao confeccionarem mosaicos, parte da geometria pouco explorada na educação básica. Em uma das mesas desenharam a rosa dos ventos, e na outra a flor de lótus e construíram todas com pedaços de cerâmica em forma de figuras geométricas.

Figura 5 - Mesas construídas pelos estudantes em formato de mosaicos.

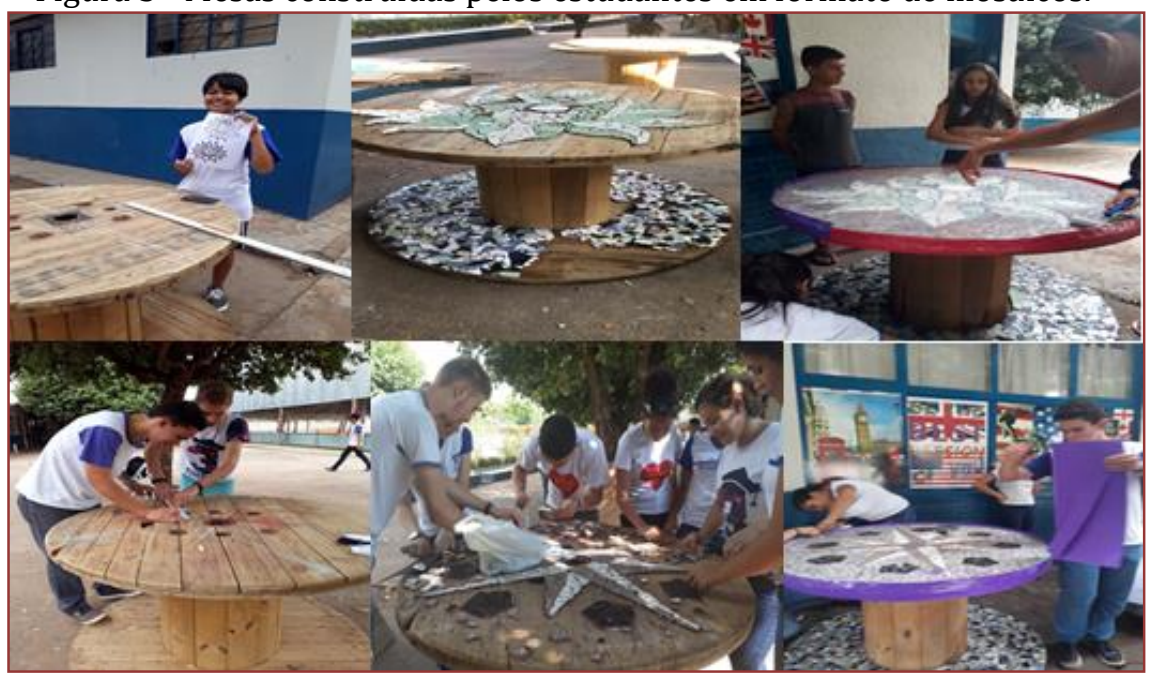


Com as mesas prontas os estudantes partiram para a construção de vasos para cultivar as plantas, eles reutilizaram pneus e cobertores velhos como na Imagem 6.

Figura 6 - Alunos construindo vasos com cimento e cobertor velhos.

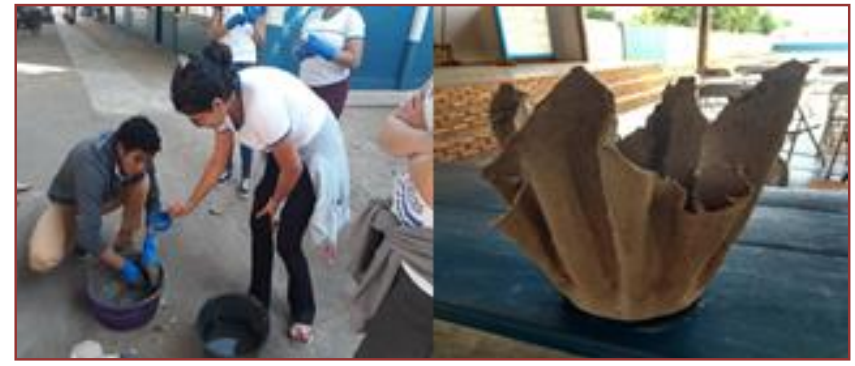

E assim, na culminância do fim do ano foi apresentado um vídeo feito pelos estudantes expondo como foi a experiência para eles e o resultado final de seus esforços como mostra a figura 7.

Figura 7 - Finalização do Jardim Ravena.

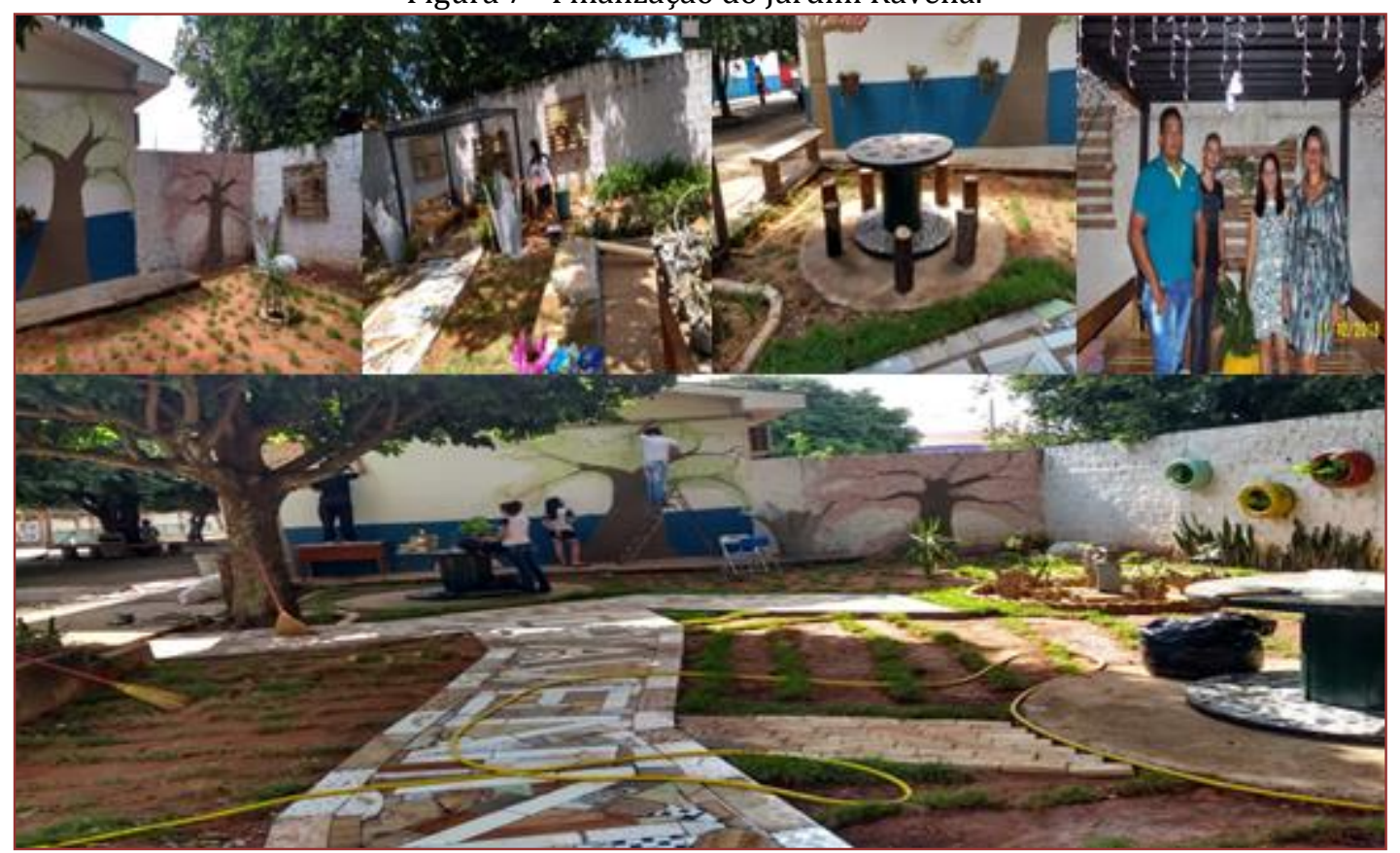

\section{CONSIDERAÇÕES FINAIS}

De acordo com as observações do professor responsável pela disciplina e registradas em seu diário de campo, durante o desenvolvimento das tarefas, a maioria dos grupos evidenciaram a capacidade de identificar figuras geométricas em situações reais, e compreenderam os conceitos de área, perímetro e volume, pois fizeram as medições do terreno e os cálculos eles mesmos e não em uma situação hipotética.

A experiência aqui relatada revelou ainda que, durante o desenvolvimento do projeto os estudantes se mostraram empolgados e empenhados. A interação e a busca por solução dos problemas encontrados mostra que a matemática quando trabalhada de maneira significativa se torna prazerosa. Assim a ideia de construir o jardim além de trabalhar o conteúdo de matemática também transformou um espaço que era abandonado em um ambiente que agradável para os alunos se reunirem, estudar e ter momentos de lazer nas horas vagas. 
Já a metodologia utilizada proporcionou aos alunos uma maior independência e autonomia, tanto na interação e troca de ideias, pois com a socialização dos resultados, em cada etapa, permitiu uma discussão de diferentes estratégias, quanto na proposição de novos questionamentos, hipóteses e conjecturas. Por fim o trabalho permitiu observar que os estudantes demonstraram maior cuidado com o ambiente escolar em especial com o jardim, uma vez que, foi construído por eles mesmos.

\section{REFERÊNCIAS}

[1] Almeida, M. E. B.; Assis, M. P. Da exclusão para a inclusão digital na escola: a apropriação das TIC na perspectiva da emancipação. São Paulo: Comitê Gestor da Internet no Brasil, 2013. p. 81-88. Disponível em: <http://www.cetic.br/publicacoes/2012/tic-educacao-2012.pdf>. Acesso em: 23 março de 2019.

[2] Fonseca, Maria da Conceição F. R. et al. O ensino de geometria na escola fundamental: três questões para a formação do professor dos ciclos iniciais. Belo Horizonte, Autêntica, 2001.

[3] Fonseca, Maria da Conceição F. R. Educação matemática de jovens e adultos: especificidades, desafios e contribuições. Belo Horizonte: Autêntica, 2005.

[4] Lima, Paulo Figueiredo; Pitombeira, João Bosco P. Fernandes de Carvalho. Geometria.In: Ministério da Educação. Matemática: Ensino Fundamental. Brasília, 2010.

[5] Lorenzato, S. Por que não ensinar geometria? Educação Matemática em Revista, São Paulo, v. 4, p. 3-13, jan. /jun. 1995.

[6] Nasser, L.; Sant'anna, N. F. P. Geometria segundo a teoria de Van Hiele. 2. ed. Rio de Janeiro: IM/UFRJ, 2010.

[7] Pavanello, Regina Maria. O abandono do ensino da geometria no Brasil: causas e consequências. Zetetiké: Revista de Educação Matemática, v. 1, p. 7-18, n. 1, 2009.t 


\section{Capítulo7}

Um relato de experiência dos redatores de Matemática do Documento Curricular - Ensino fundamental do estado do Rio Grande do Norte

\section{Luciana Vieira Andrade}

José Damião Souza de Oliveira

Josenildo Gomes de Oliveira Souza

Resumo: Este artigo apresenta um relato de experiência de três professores de Matemática da rede Estadual de Ensino do Rio Grande do Norte ao atuarem, em 2018, como redatores do Documento Curricular do Estado do RN para o Ensino Fundamental. A homologação da Base Nacional Comum Curricular do EF e o lançamento do Guia de Implementação mobilizaram secretarias estaduais e municipais de educação quanto à busca pela efetivação da BNCC nas instituições de ensino da Educação Básica. Daí, ações do Ministério da Educação ocorreram, via Programa de Apoio à Implementação da BNCC, que estabelece como frente a (re)elaboração dos currículos a partir do que está posto no documento nacional, com estados e municípios em regime de colaboração. No RN, uma versão preliminar foi posta em consulta pública e, após a análise das contribuições, transformada na versão autorizada pelo Conselho Estadual e lançada para a sociedade.

Palavras-chave: Currículo RN; Matemática; Elaboração; Regime de colaboração; Implementação. 


\section{INTRODUÇÃO}

A partir do Programa de Apoio à Implementação da Base Nacional Comum Curricular (ProBNCC) do Ministério da Educação (MEC), todos os Estados brasileiros trabalharam o ano de 2018 na (re)elaboração de seus Documentos Curriculares referentes à Educação Infantil (EI) e ao Ensino Fundamental (EF). 0 ponto de partida desta política pública foi a aprovação pelo Conselho Nacional de Educação (CNE) e a homologação da BNCC do EF, em dezembro de 2017, com posterior lançamento do Guia de Implementação da BNCC, que recomenda ações referentes à organização das secretarias estaduais e municipais de educação, em regime de colaboração, voltadas para a efetivação da Base nas escolas dos segmentos da Educação Básica supracitados.

Este artigo relata a experiência vivida pelos redatores de Matemática do Rio Grande do Norte (RN) na escrita do Documento Curricular do Ensino Fundamental que será aplicado nas escolas desse estado da Federação. Inicia por esta introdução, apresenta, na seção seguinte, alguns dos fundamentos teóricos assumidos, descreve e faz reflexões sobre o processo de escrita do referido Documento no tópico 3 e coloca uma seção 4 em que trata das primeiras práticas de formação docente e propostas para continuidade do trabalho. Além disso, há considerações finais e referências.

\section{ALGUNS FUNDAMENTOS TEÓRICOS}

Apresentamos a seguir, algumas das concepções teóricas em que nos fundamentamos durante a escrita do Documento Curricular do RN.

\subsection{CONCEPÇÃO DE CURRÍCULO}

Quanto às concepções de currículo que norteiam o trabalho proposto, destacamos algumas ideias de Sacristán (2000, p. 15) com as quais concordamos, como quando defende que "o currículo supõe a concretização dos fins sociais e culturais, de socialização, que se atribui à educação escolarizada".

Nesse sentido, a perspectiva de currículo adotada pelo RN centraliza-se no processo de aprendizagem, relacionando-o com o movimento real que faz da escola um sistema social e que, portanto, é responsável por permitir aos alunos vivenciarem práticas educativas que possibilitem a compreensão do poder emancipador do conhecimento. Dessa forma, o Documento apresenta que:

O currículo é entendido como conjunto integrado e articulado de vivências e experiências que possibilitam aos estudantes mobilizar e ampliar seus saberes em torno dos objetos de conhecimento considerados relevantes para o desenvolvimento de habilidades e competências, que são acionadas por eles na tomada de decisões, na resolução de problemas presentes na vida cotidiana, no mundo do trabalho e no exercício pleno da cidadania (SEEC-RN, 2018, p. 15).

Nessa perspectiva, também concordamos com Sacristán (2000, p. 15) ao defender que "quando definimos currículo estamos descrevendo a concretização das funções da própria escola e a forma particular de enfocá-las num momento histórico e social determinado", não sendo estático e revelando "a consciência do valor cultural da escola como instituição facilitadora de cultura" (Sacristán, 2000, p. 19).

Sendo assim, a efetivação do currículo como prática pedagógica eficiente perpassa por um verdadeiro diálogo entre os elementos que compõem a realidade escolar, a saber: alunos, professores, gestores, coordenadores, entre outros. Este pensamento pode ser percebido em textos de Sacristán (2000, p. 16) quando, por exemplo, apresenta que o currículo "é o contexto da prática, ao mesmo tempo que é contextualizado por ela."

Para D'Ambrosio (2012, p. 63), "currículo é a estratégia para a ação educativa", em nosso caso, fugimos da visão cartesiana e defendemos um currículo dinâmico e que, como diz D'Ambrosio (2012, p. 81), "reflete o momento sociocultural e a prática educativa nele inserida. 0 currículo dinâmico é contextualizado no sentido amplo" e "reconhece que nas sociedades modernas as classes são heterogêneas, reconhecendo-se entre os alunos interesses variados e enorme gama de conhecimentos prévios. Os alunos têm naturalmente grande potencial criativo" (D'ambrosio, 2012, p. 82). 


\subsection{CONCEPÇÃO DE MATEMÁTICA E DE ENSINO DE MATEMÁTICA}

Ao identificar aplicações da Matemática nos variados campos do conhecimento, reconhecemos o seu importante papel na sociedade, o que nos remete ao seu entendimento como resultado da produção humana, ou seja, como ciência que não está pronta e acabada nem é composta por verdades absolutas, mas está em constante transformação. Nessa perspectiva, atribuímos à escola a responsabilidade de promover aos estudantes o desenvolvimento de habilidades referentes à compreensão e utilização da Matemática na escola, na vida pessoal e, entre outras coisas, na vida profissional, por meio do raciocínio empenhado que se efetiva pelo exercício criativo da intuição e da imaginação. Acerca disso, D'Ambrósio (2012, p. 8) diz que vê a Matemática como "uma estratégia desenvolvida pela espécie humana, ao longo da sua história, para explicar, entender e manejar o imaginário e a realidade sensível e perceptível, bem como conviver com eles, evidentemente dentro de um contexto natural e cultural".

Por educação, D'Ambrosio (2012, p. 8) entende que é "estratégia de estímulo ao desenvolvimento individual e coletivo gerada pelos grupos culturais, com a finalidade de se manterem como tais, respeitando suas raízes culturais, e de avançarem na satisfação de necessidades de sobrevivência e de transcendência" e também conceitua como "uma estratégia da sociedade para facilitar que cada indivíduo atinja o seu potencial e para estimular cada indivíduo a colaborar com outros em ações comuns na busca do bem comum" (D'ambrosio, 2012, p. 63). Nesse sentido, pensar educação a partir de suas variantes históricas e sociais nos abre o leque para o entendimento do ensino da Matemática como importante elemento para uma formação global do indivíduo e, então, falar-se em educação para a cidadania como uma forte premissa.

A partir desse contexto e assumindo as concepções de currículo, de Matemática e de ensino de Matemática citadas, o Documento Curricular do RN propõe que os estudantes, desde os anos iniciais, vivenciem ações de "observar, analisar, estabelecer relações, perceber regularidades e buscar explicações, conjecturar, criar soluções e inventar estratégias próprias que envolvam noções, conceitos e métodos matemáticos" (SEEC-RN, 2018, p. 734). Na Matemática, especificamente, as conexões entre tais ideias visam favorecer o desenvolvimento dos pensamentos numérico, algébrico e geométrico e suas articulações, promovendo a perspectiva de que o conhecimento não é compartimentado. Para isso, indicamos o desenvolvimento de atividades investigativas em que os discentes mobilizem intuição, criatividade, conhecimentos prévios em busca da exploração de situações das mais diversas, atividades estas que ajudam

[...] a trazer para a sala de aula o espírito da atividade matemática genuína, constituindo, por isso, uma poderosa metáfora educativa. 0 aluno é chamado a agir como um matemático, não só na formulação de questões e conjecturas e na realização de provas e refutações, mas também na apresentação de resultados e na discussão e argumentação com os seus colegas e o professor. (Ponte; Brocardo; Oliveira, 2013, p. 23)

As atividades de investigação que propomos colaboram com a efetivação do currículo dinâmico a que já nos referimos e possibilitam a produção da Matemática por parte dos envolvidos e por meio do desenvolvimento de habilidades que dizem respeito a raciocinar, representar, comunicar e argumentar matematicamente, lindando, assim, com o letramento matemático, fundamental para a compreensão e a atuação no mundo.

Conforme indicado na BNCC, a essência do trabalho a ser desenvolvido na Educação Básica está em articular os diversos campos da Matemática, tratados como unidades temáticas, a saber: Números, Álgebra, Geometria, Grandezas e Medidas, Probabilidade e Estatística. Cabe a nós informar que

[...] essa divisão em unidades temáticas serve tão somente para facilitar a compreensão dos conjuntos de habilidades e de como eles se inter-relacionam. $\mathrm{Na}$ elaboração dos currículos e das propostas pedagógicas, devem ser enfatizadas as articulações das habilidades com as de outras áreas do conhecimento, entre as unidades temáticas e no interior de cada uma delas. (Brasil, 2017, p. 273)

As articulações entre as unidades temáticas acontecem entre a Matemática e as outras áreas do conhecimento, entre os diversos objetos de conhecimento da Matemática e dentro dos próprios objetos de conhecimento, sobretudo por meio de investigações e resolução de problemas. 


\section{SOBRE A ESCRITA DO DOCUMENTO CURRICULAR DO ENSINO FUNDAMENTAL DO RN.}

Com vistas a descrever o trabalho desenvolvido pelos redatores de Matemática, durante o ano 2018, quanto à elaboração do Documento Curricular do RN para o EF, esta seção do artigo apresenta e explica as principais etapas ocorridas nesta escrita.

\subsection{A EQUIPE DE REDATORES}

Em 2018, a produção do currículo foi realizada por um grupo de especialistas das diversas áreas de ensino, coordenado por profissionais da Educação que representaram o Consed (Conselho Nacional de Secretários de Educação) e a Undime (União Nacional dos Dirigentes Municipais de Educação), garantindo um trabalho realizado em regime de colaboração entre as redes estadual e municipal do RN.

De acordo com o guia de implementação, a equipe ProBNCC, responsável pela elaboração curricular, foi composta por: coordenadores estaduais de currículo (um da secretaria estadual, representando o Consed, um da Undime-RN); articulador de regime de colaboração representando a Undime-RN; um analista de gestão indicado pelo MEC, três coordenadores curriculares de etapa de ensino, sendo um para Educação Infantil, um para Anos Iniciais do EF e um para Anos Finais do EF e vinte e dois redatores de currículo, a saber, professores das redes estadual e municipal. A SEEC-RN, por meio dos coordenadores estaduais de currículo, estabeleceu dentre os critérios de seleção que os redatores deveriam estar em efetivo exercício de suas funções em escolas das redes e fossem especialistas em suas respectivas áreas. No caso da Matemática, foram três redatores, que são professores da rede estadual de ensino com experiência comprovada na área e formação em nível de pós-graduação, sendo um especialista em Ensino de Matemática e dois mestres em Ensino de Ciências Naturais e Matemática.

\subsection{AS FORMAÇõES INICIAIS}

Para articular a elaboração e fundamentar os profissionais que se responsabilizariam pela escrita, formações foram desenvolvidas pelo MEC. Nestas, redatores e coordenadores de todos os Estados da Federação tiveram a possibilidade de trocar experiências e de socializar informações sobre o andamento de seus trabalhos.

A primeira formação para a equipe ProBNCC ocorreu no período de 26 a 28 de março de 2018, em Brasília-DF, realizado pelo MEC, em parceria com Consed e Undime e com o apoio da Universidade de Brasília (UnB). Na ocasião, foram dadas as orientações iniciais às equipes técnicas e de gestão das unidades federativas acerca de como deveria ocorrer a (re)elaboração dos currículos, à luz da BNCC.

A SEEC-RN instituiu um Dia D de estudo da BNCC nas escolas para que os profissionais pudessem entender a proposta de uma maneira mais ampla e também favorecer as contribuições que deles viriam em seguida, na consulta pública.

Em junho desse mesmo ano, aconteceram encontros de formação para escrita do currículo, ocasião em que foram discutidas as diretrizes deste trabalho. Ocorreram na Escola do Governo, com a participação de toda equipe ProBNCC e também outros professores da rede pública, no sentido de socializar o que já havia sido produzido quanto à proposta curricular do RN e propiciar reflexões e discussões sobre este.

\section{A ESCRITA DA VERSÃO PRELIMINAR}

Paralelo a tais formações, no decorrer do ano 2018, os documentos curriculares estaduais iam sendo elaborados no Brasil.

Nesse sentido, conhecer o histórico, as pluralidades e as diversidades dos documentos curriculares existentes nos municípios do RN era pertinente, já que a SEEC-RN não possuía um capaz de representar todo o estado. Havia, então, a necessidade de estudar e entender a proposta da BNCC, para esclarecer algumas diretrizes que delineassem os princípios norteadores deste documento normativo. Isto, com o intuito de estabelecer as concepções que seriam assumidas pelos envolvidos na escrita do Documento Curricular com vistas à produção de um documento que representasse, de fato, o RN. 
Essa preparação aconteceu paralela à produção propriamente e envolveu ainda discussões e reflexões sobre processos de avaliação, metodologias, habilidades, exemplos de propostas de trabalho interdisciplinar, estratégias para contemplar diversidades locais, temas integradores, sugestões/orientações didáticas para cada componente curricular, bem como, o estabelecimento do modelo de estrutura do documento curricular que se construía.

\subsection{OS SEMINÁRIOS DE MOBILIZAÇÃO}

No RN, com uma versão preliminar do documento já produzida, em julho de 2018, aconteceram seminários de mobilização, direcionados aos coordenadores pedagógicos das escolas estaduais e gestores municipais, a fim de orientá-los quanto à consulta pública que aconteceria em seguida, de modo que estes atuariam como multiplicadores em suas escolas e/ou municípios, orientando, posteriormente, os professores a contribuírem com este trabalho. Nestes encontros, apresentamos a plataforma destinada à consulta e orientamos quanto a sua utilização.

Sabendo da dificuldade de mobilizar todos os integrantes das equipes citadas, os redatores foram orientados a realizar versões destes seminários nas escolas onde atuam e em demais locais para que pudéssemos alcançar o maior número possível de educadores e a sociedade civil, pois sabemos que a educação é dever de todos.

Estes seminários aconteceram com o ideal de atingir todo o RN e, para isso, foram realizados na capital (Natal), em Mossoró e em Caicó, municípios onde há polos da SEEC-RN. Nestes momentos, atingimos cerca de quatro mil participantes, o que mostra um efetivo interesse dos envolvidos no regime de colaboração.

\section{A CONSULTA PÚBLICA E SEUS DESDOBRAMENTOS}

Após os seminários de mobilização, foi disponibilizada uma plataforma digital, no período de 03 a 31 de agosto de 2018, em que todos tiveram acesso à versão preliminar do Documento, para apreciação e inserção de contribuições em todos os componentes curriculares. A consulta pública foi destinada à divulgação e análise da versão preliminar, onde este foi depositado em plataforma on-line e subdivido em seções, pois entendemos não ser necessário que os participantes analisassem o Documento na íntegra, mas que pudessem se dedicar apenas ao ano de escolaridade de seu interesse, por exemplo, poderíamos ter um(a) professor(a) do segundo ano do EF, e este(a) desejasse analisar e colaborar com apenas este ano de ensino, então o(a) mesmo(a) poderia acessar o conteúdo específico e realizar suas contribuições.

Paralelo a isso, os redatores continuavam com a escrita do Documento. Além disso, a equipe ProBNCC realizava reuniões para discutir e estabelecer os critérios de análise das contribuições oriundas da consulta pública.

Finalizada a consulta pública, houve um período da categorização das contribuições e, então, a consolidação do Documento curricular. Considerando os critérios estabelecidos para análise, os redatores de cada área investigaram as contribuições uma a uma e classificaram quanto ao aceite ou não aceite. No caso específico de Matemática, gostaríamos de destacar, que tivemos contribuições aceitas integralmente e contribuições aceitas parcialmente, contudo destacamos que o Documento foi consideravelmente enriquecido a partir das colaborações recebidas. Assim, chegamos a uma nova versão do Documento curricular, a qual seria enviada para apreciação do Conselho Estadual de Educação (CEE).

\subsection{OS SEMINÁRIOS PARA DEVOLUTIVA DOS RESULTADOS DA CONSULTA PÚBLICA}

Uma nova etapa de seminários aconteceu, com o intuito de apresentar uma devolutiva sobre a consulta pública. Para estes seminários foram convidados os profissionais que efetivamente contribuíram. A estes, foram apresentados resultados da consulta, entre eles, critérios de análise, os municípios que mais opinaram por componente, quantidade de participações. Além disso, em Matemática, refletimos sobre as concepções de área que assumimos. Desta vez, foram realizados em Natal, Caicó e Pau dos Ferros, município este que também sedia um dos polos da SEEC-RN. 


\subsection{LANCAMENTO DO DOCUMENTO CURRICULAR}

Ao fim da escrita, foi encaminhado ao CEE que analisou e aprovou possibilitando a apresentação do Documento Curricular do RN - Ensino Fundamental à sociedade. 0 lançamento oficial ocorreu em 07 de dezembro de 2018, em evento na Escola de Governo que contou com a presença de todos que trabalharam na escrita e de autoridades que na época representavam a educação do Estado do Rio Grande do Norte.

Salientamos que embora esta última tenha sido a versão aprovada pelo Conselho e que será implementada nas escolas nos próximos anos, não entendemos que seja uma versão final, pois conforme as concepções apresentadas em seções anteriores, o currículo é dinâmico e, portanto está em constante transformação, o que nos remete ao dinamismo inerente ao processo educacional.

\subsection{AS PRIMEIRAS PRÁTICAS DE FORMAÇÃO DOCENTE E PROPOSTAS PARA CONTINUIDADE DO TRABALHO}

Como previa o Programa ProBNCC, com o Documento aprovado e lançado, as etapas seguintes dizem respeito às formações aos docentes das redes a partir das quais será possível se delinear a implantação do que ele defende para a prática da sala de aula.

No início de 2019, já durante semanas pedagógicas das escolas, fizemos algumas participações com apresentações que visavam tratar do trabalho desenvolvido no ano anterior quanto à produção do Documento Curricular do RN.

Nestas ocasiões, citamos os documentos que antecederam/embasaram a BNCC (Constituição Federal, Lei de Diretrizes e Bases, Diretrizes Curriculares Nacionais, Plano Nacional de Educação), para ratificar o caráter de documento referencial obrigatório para todos os documentos curriculares da federação. Também falamos sobre as formações que participamos, pelo MEC, apresentamos a estrutura da BNCC e alguns de seus fundamentos pedagógicos. Além disso, fizemos um breve histórico da construção do Documento Curricular do RN, elencando os tópicos: instuição da equipe ProBNCC, as formações, o processo de escrita, a versão preliminar, a consulta pública, a versão pós contribuições, a homologação do mesmo pelo Conselho Estadual de Educação e o lançamento. Apresentamos a estrutura do quadro organizador curricular e algumas abordagens/concepções do componente Matemática, com ênfase ao ensino da Matemática a partir do desenvolvimento de competências e habilidades. Para tanto, refletimos sobre a perspectiva de resolução de problemas e propomos algumas atividades práticas.

Concordando com D'Ambrosio (2012, p. 9) quando diz que "as fases ou processos fundamentais por meio dos quais o currículo se conforma como prática realizada num contexto”, nossas participações nas escolas tiveram o objetivo de iniciar as formações dos professores quanto à aplicação do currículo em sua prática. Entretanto as formações amplas para os docentes das redes estadual e municipal estão sendo alinhadas pelas equipes responsáveis do MEC e da SEEC-RN e estão previstas para acontecerem no decorrer deste ano.

\section{CONSIDERAÇÕES FINAIS}

Consideramos neste relato a importância de divulgar, à comunidade da Educação Matemática, os meios e/ou caminhos trilhados pelos redatores do Documento Curricular do RN para o EF, na área da Matemática, onde expusemos o processo de elaboração detalhando as etapas seguidas, desde a formação da equipe até chegarmos à versão homologada pelo Conselho Estadual de Educação do RN e lançada à sociedade. Os próximos passos dizem respeito à efetivação de propostas de formação docente. Na prática, estas etapas já foram iniciadas com as participações dos redatores em jornadas pedagógicas de escolas e/ou municípios, contudo sabemos que para o alcance efetivo da implantação do currículo nas instituições de ensino são necessários processos contínuos de formação para os profissionais da educação, formações estas que estão previstas para ocorrerem ao longo do ano de 2019. 


\section{REFERÊNCIAS}

[1] Brasil. Ministério da Educação Secretaria da Educação Básica. Base Nacional Comum Curricular para o Ensino Fundamental (BNCC). Brasília, 2017.

[2] D’ambrosio, U. Educação Matemática: da teoria à prática. 23ํㅡ ed. Campinas. Papirus. 2012.

[3] Ponte, J. P. da, Brocardo, J., Oliveira, H.. Investigações matemáticas na sala de aula. 3ª ed. Ver. Ampl. Belo Horizonte. Autêntica. 2013.

[4] Sacristán, J. G.. O currículo: uma reflexão sobre a prática. Trad. Ernani F. da F. Rosa. 3ª ed. Porto Alegre. Artmed. 2000.

[5] SEEC-RN. Secretaria de Estado da Educação e da Cultura. Documento Curricular do Rio Grande do Norte: Ensino Fundamental, Natal. Offset, 2018. 


\section{Capítulo 8}

Educação Matemática Realística: Uma abordagem de ensino que pode oportunizar a aprendizagem Matemática a todos os alunos

\section{Marta Burda Schastai \\ Lidia Schactai Silvano}

Resumo: No presente artigo apresentamos a Educação Matemática Realística (RME) e os seus princípios. A RME é uma abordagem para o Ensino de Matemática pautada nas ideias de Hans Freudenthal que pode ser utilizada, por professores e coordenadores pedagógicos, como "guia" para um ensino de matemática que tem como meta oportunizar a aprendizagem a todos os alunos de uma sala de aula, independentemente do nível que se encontram. A fundamentação teórica está pautada nos escritos originais de Freudenthal (1968, 1973); Heuvel (2010); Streefland (1991); Widjaja e Heck (2003) e na tese de Ferreira (2013). Com o objetivo de clarificar/exemplificar como se dá a prática letiva apresentamos características da dinâmica de sala de aula destacando o papel do professor e o papel do aluno, dentro dessa abordagem de ensino, por meio do relato de uma prática de sala de aula de um professor do Ensino Médio. Concluímos que, a concepção de Matemática como atividade humana faz toda diferença em relação ao processo de ensino e aprendizagem matemática. 0 foco do ensino e da aprendizagem deixa de ser o resultado do processo e passa a ser o processo de matematização, com isso, têm-se uma outra dinâmica de sala de aula, para além daquela tradicional. As tarefas propostas aos alunos dão a oportunidade a todos de se envolverem na atividade, aprenderem matemática fazendo matemática.

Palavras-chave: Ensino, Educação Matemática Realística, Matemática, dinâmica de sala de aula. 


\section{INTRODUÇÃO}

Um dos objetivos da Educação para Todos que consta na Declaração de Dakar é o de "melhorar todos os aspectos da qualidade da educação e assegurar excelência para todos, de forma a garantir a todos resultados reconhecidos e mensuráveis, especialmente na alfabetização, matemática e habilidades essenciais à vida" (UNESCO, 2001, p.2).

Nesse sentido, na disciplina de Matemática, é desejável que todos os estudantes tenham a oportunidade de aprender os conhecimentos que fazem parte da grade curricular do ano/série em que se encontram e que essa aprendizagem desencadeie novas e/ou outras aprendizagens que se apresentem ao longo da vida.

Entretanto, na maioria das escolas brasileiras, observa-se um distanciamento - um fosso - entre a aprendizagem desejável e a aprendizagem que ocorre no interior da maioria das salas de aula. Os resultados da Avaliação Nacional do Rendimento Escolar - ANRESC (conhecida como Prova Brasil) que tem com o objetivo de avaliar a qualidade do ensino ministrado nas escolas públicas (Brasil, 2013) apontam nessa direção e, de certa forma, essa avaliação também vincula os resultados da aprendizagem que se manifestam no rendimento escolar ao ensino. Se o resultado da aprendizagem não é satisfatório é possível que haja algum entrave no ensino.

No que diz respeito as práticas de ensino é comum encontramos, como parte da dinâmica de sala de aula quando vários alunos de uma mesma turma não aprendem um determinado conteúdo, ou seja, quando obtém notas inferiores à média pré-estabelecida pelo Sistema de Ensino, a prática de "fazer revisão do conteúdo trabalhado". Revisar um conceito, um algoritmo, um conteúdo matemático é suficiente para que o aluno construa seu conhecimento matemático? Essa é uma questão de ensino para se pensar.

Oportunizar a construção/elaboração do conhecimento matemático, por meio do fazer matemática, a todos os alunos de uma sala de aula, certamente requer mais do que revisar, explicar, mostrar, exercitar técnicas operatórias. É necessário pensar o ensino de uma outra forma, de um outro ponto de vista.

Nessa perspectiva, apresentamos a RME como uma abordagem de ensino que pode oportunizar a aprendizagem a todos os alunos de uma sala de aula independentemente do nível em que se encontram.

\section{EDUCAÇÃO MATEMÁTICA REALÍSTICA}

A Educação Matemática Realística (RME) é uma abordagem de ensino baseada nas ideias do matemático alemão Hans Freudenthal. Essa abordagem surgiu na Holanda entre o final de 1960 e início de 1970, época em que os educadores holandeses estavam em busca da modernização da Educação Matemática, visando uma reforma educacional que fosse oposta ao movimento da Matemática Moderna que tinha como base o ensino estruturalista (Ferreira, 2013).

O termo "realística" se refere a situações que podem ser imaginadas. Os problemas apresentados para os alunos podem ser do mundo real, mas também podem ser do mundo da fantasia, dos contos de fada ou mesmo do mundo formal da matemática, desde que eles sejam reais na mente do aluno. 0 importante é que as situações (ou problemas) sejam adequados para matematização, que os alunos consigam imaginar algo e possam fazer uso de suas próprias experiências e conhecimentos para resolvê-las. É esta ênfase em tornar algo real na mente que deu origem ao nome de Educação Matemática Realística. (Heuvel-Panhizen, 2000).

A RME tem seis princípios que guiam o trabalho de sala de aula. São eles: da atividade, da realidade, de níveis, do entrelaçamento, da interatividade e da orientação.

\subsection{PRINCÍPIO DA ATIVIDADE}

Esse princípio se baseia na ideia, de Freudenthal, de matemática como atividade humana. Para Freudenthal "o que os seres humanos têm de aprender não é a Matemática como um sistema fechado, mas sim como uma atividade, como processo de matematização da realidade e, se possível, de matematização da matemática" (Freudenthal, 1968, p.7, tradução nossa). Nessa perspectiva os alunos são participantes ativos no processo de aprendizagem. Para Freudenthal (1973) transferir a matemática pronta diretamente para os estudantes é uma inversão anti-didática que não funciona.

Inerente ao conceito de matemática como atividade humana é ideia de que a Educação Matemática Realística nunca pode ser considerada uma teoria fixa ou acabada da Educação Matemática, é vista como um "trabalho progressivo" (Heuvel-Panhuizen, 1998). 


\subsection{PRINCÍPIO DA REALIDADE}

O princípio da realidade refere-se a função da RME de tornar os alunos capazes de aplicar matemática nas situações que se apresentam, não só ao final do processo mas também no início (Heuvel-Panhuizen, 2010). Deve-se "ensinar matemática de forma a ser útil" (Freudenthal, 1968, p.3). É importante o uso de contextos significativos e naturais ao aluno como ponto de partida para sua aprendizagem (Widjaja; Heck, 2003).

\subsection{PRINCÍPIO DE NÍVEIS}

O princípio de nível diz respeito a aprendizagem dos alunos. Ela passa por vários níveis de compreensão começando com seus procedimentos informais e por meio da matematização progressiva e esquematizações avançando para a construção de modelos mais formais (Heuvel-Panhuizen, 2010). Os modelos têm de mudar de uma situação particular "modelo de" para outras situações equivalentes "modelo para" (Streefland, 1991).

\subsection{PRINCÍPIO DO ENTRELAÇAMENTO}

O princípio do entelaçamento diz respeito aos domínios matemáticos, como geometria, número, medidas e tratamento da informação que não são considerados capítulos curriculares isolados, mas fortemente integrados (Heuvel-Panhuizen, 2010). Este princípio também se aplica aos tópicos dentro de domínios, assim, por exemplo, no domínio dos números, o sentido do número, a aritmética mental, estimativa e algoritmos são ensinados em estreita ligação entre si. A força do princípio do entrelaçamento é que traz coerência para o currículo (Heuvel-Panhuizen, 2000).

\subsection{PRINCÍPIO DA INTERATIVIDADE}

O princípio da interatividade considera que a aprendizagem da matemática não é apenas uma atividade pessoal, é também uma atividade social. Nessa perpectiva os alunos devem ter oportunidades para compartilhar suas estratégias e invenções com outros alunos (Heuvel-Panhuizen, 2010). Também a interação entre alunos e professores é importante porque a discussão e a colaboração oportunizam a reflexão sobre o trabalho (Widjaja; Heck, 2003).

\subsection{PRINCÍPIO DE ORIENTAÇÃO}

O princípio de orientação refere-se a ação do professor. Aos alunos deve ser dada a oportunidade "guiada" para "reinventarem" a matemática (Heuvel-Panhuizen, 2010). Os professores devem proporcionar um ambiente que funcione como uma alavanca para atingir mudanças nos níveis de compreensão dos alunos. 0 ensino e os programas devem estar alicerçados em uma trajetória de ensino-aprendizagem a longo prazo (Heuvel-Panhuizen, 2010).

\section{UMA PRÁTICA DE SALA DE AULA}

A prática de sala de aula relatada a seguir foi desenvolvida em uma turma do $2^{\circ}$ ano do Ensino Médio do período noturno em uma escola da rede pública de ensino, no primeiro semestre de 2016. Essa turma era composta por 38 alunos que freqüentavam as aulas regularmente, com faixa etária entre 17 e 23 anos.

\subsection{DINÂMICA DA SALA DE AULA}

Inicialmente o professor, em seu planejamento, selecionou o problema dos apertos de mãos para propor aos alunos com o objetivo de trabalhar com a Análise Combinatória.

Enunciado do primeiro problema:

Numa reunião de equipe há 8 alunos. Se cada um trocar um aperto de mão com todos os outros, quantos apertos de mão teremos ao todo? 
1a aula: A primeira aula teve duração de $1 \mathrm{~h} 40 \mathrm{~min}$.

No início da aula, os alunos receberam o problema dos apertos de mãos impresso em uma folha sulfite. Nessa folha também haviam duas instruções: o problema deveria ser resolvido individualmente e que teriam 20 minutos para essa tarefa.

Após o período de 20 minutos, o professor solicitou que cada aluno falasse o resultado obtido. Na medida em que os alunos falavam o professor registrava na lousa todos os resultados, mesmo os repetidos. Ao final desse procedimento os alunos constataram que haviam sido registrados oito resultados distintos: 64, $7,56,8,28,32,36$ e 4 .

Na seqüência o professor formou duplas com alunos que obtiveram resultados diferentes para que os mesmos conversassem a respeito de como obtiveram aquelas respostas e chegassem a conclusão de qual era mais adequada ao problema, e novamente indicassem as respostas, ficando desta vez registrados na lousa cinco resultados: 64, 56, 32, 36 e 28.

Obedecendo a mesma sistemática, as duplas foram agrupadas duas a duas, formando sete grupos com quatro alunos e dois grupos com cinco alunos, para conversarem novamente a respeito de como obtiveram aquelas respostas e chegassem a conclusão de qual das duas respostas era mais adequada ao problema. Desta conversa, obteve-se dois resultados: um grupo estava convicto de que a resposta adequada era 36 e oito grupos chegaram a conclusão de que a resposta adequada era 28.

0 professor solicitou um representante do grupo que indicou a resposta 36 e um representante dos que indicaram a resposta 28 para apresentarem a estratégia e os procedimentos utilizados na resolução do problema.

Prontamente um aluno, do grupo que indicou a resposta 28, dirigiu-se à frente e convidou mais sete colegas que representaram a resolução do problema por meio dos apertos de mão.

Os 8 alunos se posicionaram lado a lado, na frente da lousa, o primeiro aluno cumprimentou os demais, fazendo a contagem do número de apertos de mãos e registrou na lousa a quantidade sete, se retirando da formação e permanecendo na lousa para registrar os demais resultados; na seqüência o segundo aluno cumprimentou os demais e retornou para sua carteira, sendo registrado mais seis apertos de mãos; o terceiro aluno fez o mesmo procedimento, sendo registrado mais cinco apertos de mãos; obedecendo o mesmo procedimento para o quarto aluno foi registrado mais 4 apertos de mãos; para o quinto mais três apertos de mão; para o sexto mais dois apertos de mãos, para o sétimo aluno foi registrado mais um aperto de mão e o oitavo aluno não registrou nenhum, pois todos os demais já o haviam cumprimentado. 0 aluno que representava o grupo, fez a adição dos apertos de mãos realizados e obteve a resposta 28.

Ao final desta etapa os alunos que indicaram 36 como resposta imediatamente comentaram que haviam utilizado a mesma estratégia e procedimento do grupo anterior, porém que cometeram um equívoco, ao invés de considerarem 8 elementos conforme indicado no enunciado do problema, incluíram um integrante a mais, ficando com 9 elementos.

$2^{\text {a }}$ aula: A segunda aula teve duração de $1 \mathrm{~h} 40 \mathrm{~min}$.

Na segunda aula o foco não estava mais na resolução do problema, mas nas estratégias e procedimentos utilizados pelos alunos para obterem a resposta 28.

Inicialmente, alguns alunos foram até a lousa e apresentaram a maneira por meio da qual obtiveram o resultado. Também entregaram suas resoluções para o professor.

0 primeiro aluno fez uma lista com nomes de 8 colegas da sala e suas combinações, conforme "Figura 1". 
Figura 1 - Resolução apresentada pelo primeiro aluno.

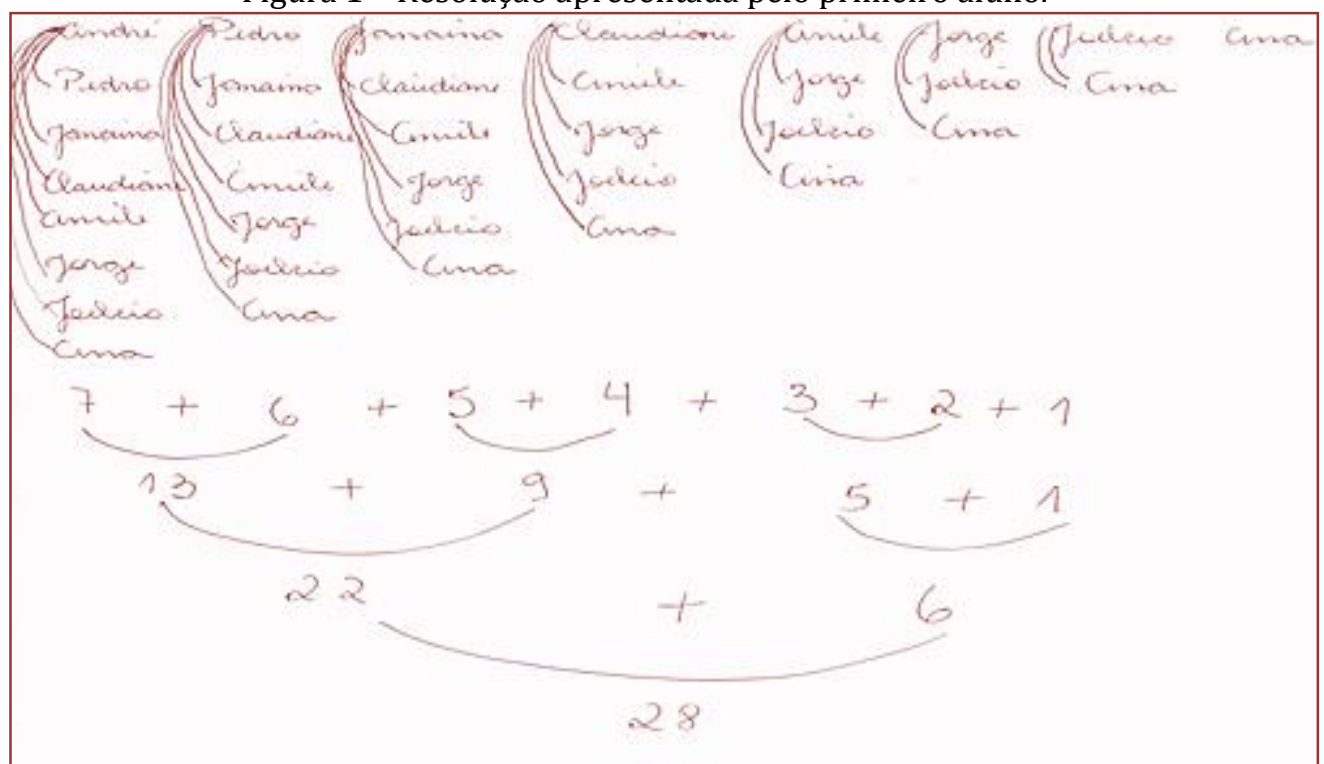

Fonte: Acervo das autoras

0 professor perguntou aos demais alunos se mais alguém havia feito da mesma maneira. A grande maioria, ou seja, 31 alunos afirmaram que utilizaram o mesmo procedimento, com variações de nomes e distribuição das escritas na folha.

O segundo aluno apresentou uma variação da estratégia apresentada pelo primeiro, utilizado-se de números ao invés de nomes, conforme "Figura 2".

Figura 2 - Resolução apresentada pelo segundo aluno.

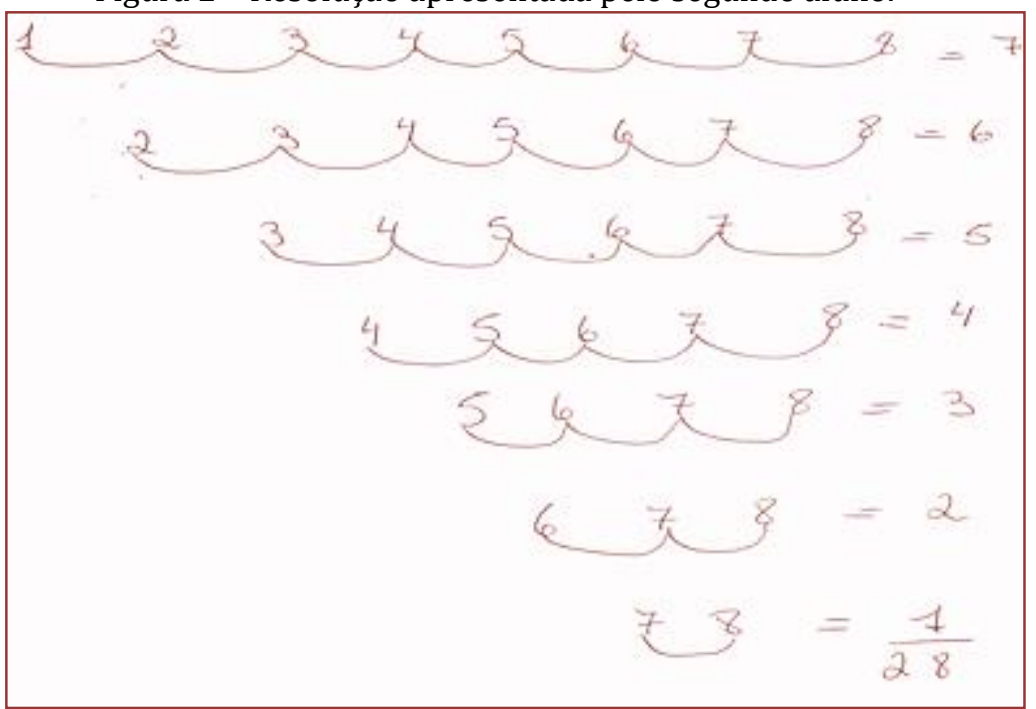

Fonte: Acervo das autoras.

Quando questionado como havia pensado para fazer essa representação, o aluno explicou "0 aluno de número 1 cumprimentou o aluno de número 2 , depois o de número 3 e assim sucessivamente resultando em 7 apertos de mãos dados pelo aluno 1. Como o aluno de número 1 já tinha cumprimentado todos os alunos ele não iria mais cumprimentar nem ser cumprimentado por isso ele ficou de fora, depois foi a vez do segundo aluno cumprimentar..." Este procedimento também foi utilizado por mais dois alunos, com algumas variações de distribuição na folha. 
0 terceiro aluno relatou que lembrou do Produto Cartesiano - da formação de pares ordenados. A partir dessa ideia fez a combinação conforme consta na "Figura 3".

Figura 3 - Resolução apresentada pelo terceiro aluno.

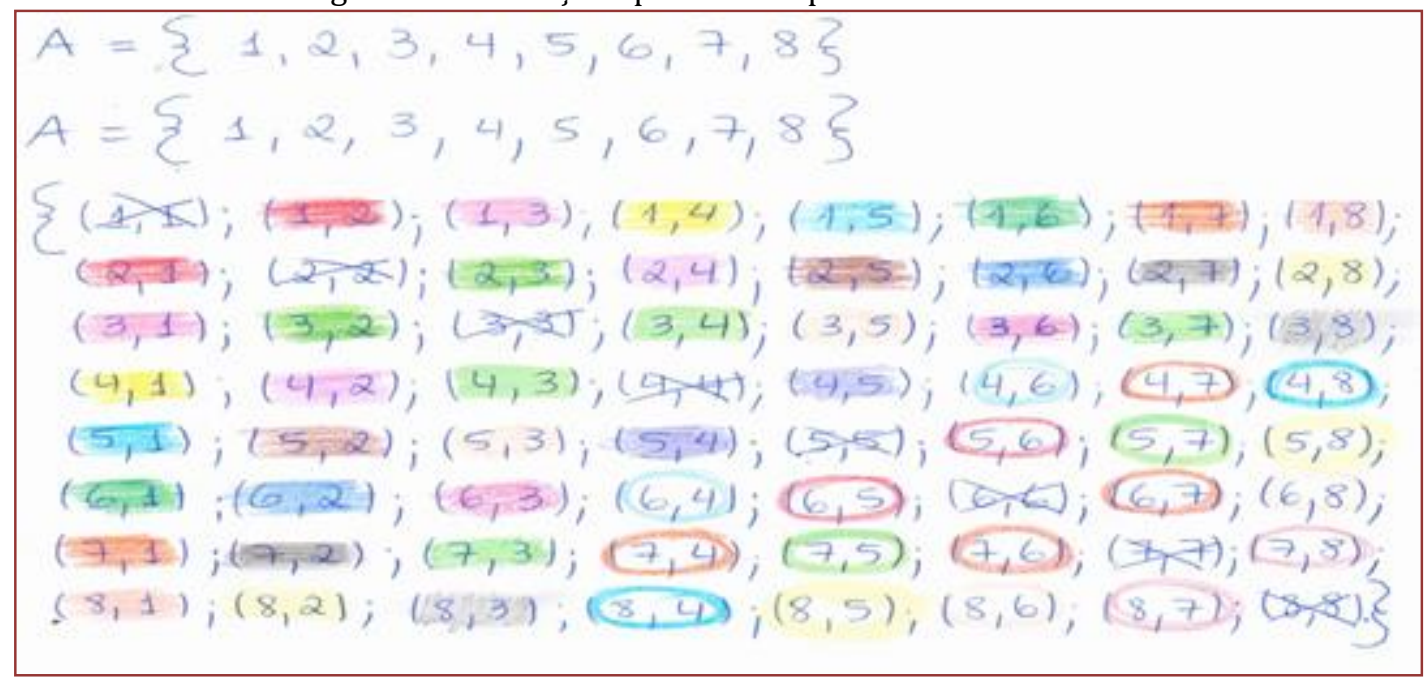

Fonte: Acervo das autoras.

Esta estratégia também foi utilizada por mais um aluno. Esses dois alunos comentaram que tiveram a ideia de Produto Cartesiano depois de terem percebido que nenhuma de suas respostas era adequada ao problema, um havia obtido $64(8 \times 8)$ e o outro 8 (8x1). Ao representarem os pares ordenados perceberam que poderiam "melhorar" a resposta do primeiro aluno excluindo os pares $(1,1) ;(2,2) ;(3,3) ;(4,4) ;(5,5)$; $(6,6) ;(7,7)$ e $(8,8)$, com a alegação de que uma pessoa não se cumprimenta. Também comentaram que ao verbalizar o aluno 1 cumprimenta o aluno 2, o aluno 2 cumprimenta o aluno 1 perceberam que nesse caso, teriam que contar uma única vez e foram marcando os pares com a mesma cor. Comentaram que só no final perceberam que era "mais fácil" fazer 64 - 8 = 56 e dividir o 56 por 2 para obter a resposta 28.

O quarto aluno, o único que havia indicado o resultado 28 como adequado desde o início da primeira aula, apresentou o cálculo utilizado conforme "Figura 4".

Figura 4 - Resolução apresentada pelo quarto aluno.

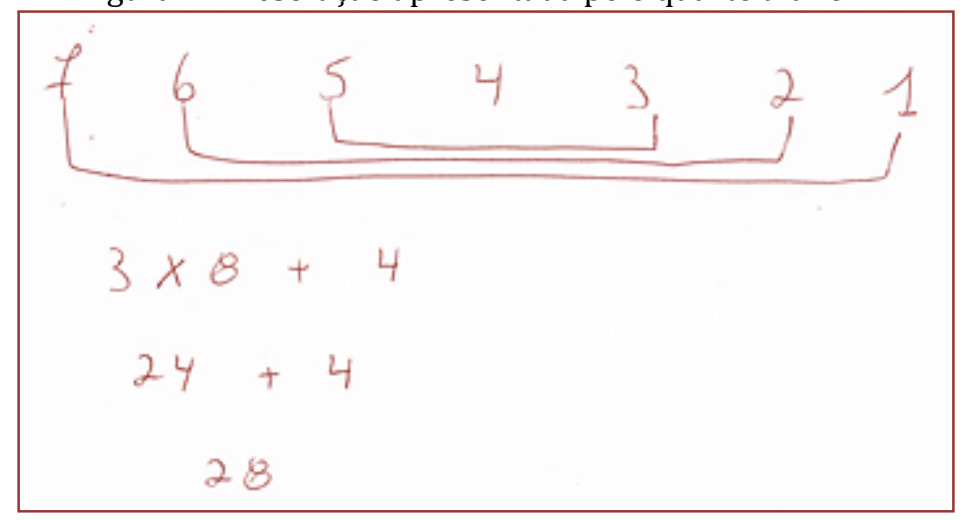

Fonte: Acervo das autoras.

Esse aluno comentou que conseguia visualizar a situação dos apertos de mãos conforme Figura 1 e que não precisava fazer a representação e que de imediato vinha a sua mente o cálculo a ser realizado $7+6+5$ $+4+3+2+1$. Ele também comentou que sua preocupação era em encontrar um "jeito diferente" de fazer a adição.

Após este encaminhamento, o professor perguntou aos alunos: Qual das estratégias foi a mais adequada para a resolução do problema? 
Os alunos responderam que todas as estratégias levam ao mesmo resultado e que a escolha só depende da preferência de cada um, entretanto, os procedimentos de cálculo apresentados pelos dois primeiros alunos foram considerados pela maioria dos alunos como sendo "mais fáceis".

Depois disso, o professor propôs outro problema para ser resolvido.

Enunciado do segundo problema:

Numa reunião de equipe há 8 alunos. Se cada um trocar um aperto de mão com todos os outros, quantos apertos de mão teremos ao todo?

Numa reunião há 392 alunos. Se cada um trocar um aperto de mão com todos os outros, quantos apertos de mão teremos ao todo?

Neste momento, percebendo a inviabilidade da aplicação dos procedimentos apresentados pelo primeiro e segundo aluno, os alunos solicitaram ao professor a fórmula que pode ser utilizada para resolver este problema.

O professor solicitou que os mesmos retomassem o conteúdo Progressão Aritmética (PA), mais especificamente a soma dos termos de uma PA que haviam sido trabalhados no primeiro ano do Ensino Médio e comparassem com o procedimento utilizado pelo quarto aluno e que estudassem no livro didático o conteúdo Análise Combinatória, mais especificamente a combinação e comparassem com o procedimento apresentando pelo terceiro aluno.

A partir da apresentação dos estudos dos alunos foi sistematizada a fórmula da soma dos termos de uma PA como parte de um procedimento que pode ser utilizado na resolução deste problema e foi iniciado o trabalho com Análise Combinatória.

\section{DISCUSSÕES}

A Educação Matemática Realística não é um método, mas uma abordagem de ensino que tem como alicerce os princípios: da atividade, da realidade, de níveis, do entrelaçamento, da interatividade e da orientação. Esses princípios norteiam a dinâmica de sala de aula, a ação do professor e do aluno, a trajetória de ensino-aprendizagem. Na RME não há um modelo de "aula padrão", o que há são aulas baseadas nos princípios.

Na dinâmica de sala de aula ora descrita podemos encontrar indícios da presença dos princípios da Educação Matemática Realística.

Princípio da atividade: Aos alunos não foram dadas instruções quanto as estratégias e procedimentos a serem utilizados na resolução do problema dos apertos de mãos - como frequentemente acontece nas aulas tradicionais. Os alunos foram os autores de suas resoluções, sendo estas "refinadas" nas discussões com seus colegas, exercendo papel ativo na construção de suas aprendizagens.

Princípio da realidade: 0 problema dos apertos de mãos, como um ponto de partida para o ensino do tema matemático Combinação, constituiu-se em um contexto significativo e natural para os alunos. Os alunos conseguiram imaginar a situação, resolvê-la com seus próprios conhecimentos e a partir desse contexto aprender uma matemática mais avançada.

Princípio de níveis: Os alunos, independentemente do nível que se encontravam tiveram a oportunidade de resolver o problema dos apertos de mãos, iniciando com procedimentos informais (representações) e avançando por meio de esquematizações na construção de modelos mais formais.

Princípio do entrelaçamento: 0 princípio do entrelaçamento se revela na relação entre os diferentes temas matemáticos, por exemplo, na resolução do quarto aluno que se utiliza da soma dos elementos de uma Progressão Aritmética ou na resolução do terceiro aluno que se utiliza do Produto Cartesiano para organizar a combinação dos apertos de mãos.

Princípio da interatividade: Os alunos tiveram a oportunidade de compartilhar suas estratégias e procedimentos com outros alunos por meio da dinâmica estabelecida pelo professor, trabalhando individualmente, em duplas e em grupos em uma fase inicial e posteriormente no grande grupo (com todos os alunos da turma). 
Princípio da orientação: 0 professor, desde o momento em que propôs a resolução do problema dos apertos de mão, não disse o que fazer para resolver o problema. Ao contrário, organizou a dinâmica de sala de aula de tal forma que os alunos tivessem a oportunidade de construírem seus conhecimentos, ocupando o papel de "guia" para reinventarem a matemática.

Os princípios da Educação Matemática Realística norteiam ou estão presentes na dinâmica dessa sala de aula que prioriza a interação, a participação ativa do aluno e o professor como "guia".

\section{CONSIDERAÇÕES FINAIS}

A Educação Matemática Realística é uma abordagem de ensino para todos dos alunos de uma turma (Heuvel, 2010). A ideia de Freudenthal (1968) de Matemática como uma atividade humana e não como resultado ou como um sistema fechado interfere na forma de como se vê a aprendizagem e de como se vê o ensino.

Na perspectiva da Educação Matemática Realística aprender matemática não é aprender o resultado do processo de matematização como um sistema fechado, mas é aprender a atividade, o processo de matematização da realidade e se possível da própria Matemática (Freudenthal, 1968).

Enquanto os alunos resolvem o problema eles aprendem a resolvê-lo e guiados pelo professor avançam para níveis mais elevados de conhecimentos matemáticos.

A partir do princípio da atividade é necessário pensar nas tarefas a serem propostas para os alunos, no uso de contextos que possibilitem o processo de matematização, que sejam realísticos, ou seja, que possam ser imaginados pelos alunos desencadeando o fazer matemática. 0 enunciado de uma tarefa deve se tornar um "problema" (e não apenas um amontoado de palavras) para o aluno e deve ser de tal forma que pode ser resolvido com diferentes matemáticas (da informal até a formal) passando por vários níveis de complexidade. Essas tarefas são essenciais para que todos os alunos se envolvam com a proposta e tenham a oportunidade de aprender matemática, cada qual em seu nível, com possibilidade de alçar a níveis mais elevados.

Advindo da ideia de Matemática como atividade humana a dinâmica de sala de aula favorece a interação, a construção do conhecimento matemático; o aluno é considerado como sujeito ativo que aprende matemática fazendo matemática e o professor atua como "guia" no processo de ensino e aprendizagem.

\section{REFERÊNCIAS}

[1] Brasil. INEP - Instituto Nacional de Estudos e Pesquisas Educacionais Anísio Teixeira. Disponível em: < http://portal.inep.gov.br/web/saeb/resultados-2013 >_Acesso em:15 jul. 2016.

[2] Ferreira, P. E. A. Enunciados de tarefas de matemática - um estudo sob a perspectiva da Educação Matemática Realística. 2013, 121f. Teses. (Doutorado em Ciências e Educação Matemática) Universidade Estadual de Londrina. Londrina- Pr.

[3] Freudenthal, H. Mathematics as an educational task. Dordrecht: D. Reidel Publishing Company, 1973.

[4] Freudenthal, H. Why to Teach Mathematics so as to Be Useful. Educational Studies in Mathematics, v. 1, n. 12, p. 3-8, 1968.

[5] Heuvel-Panhuizen. Realistic Mathematics Education as work in progress. In: LIN, F. L. (Ed.). Common Sense in Mathematics Education. Proceedings of 2001 The Netherlands and Taiwan Conference on Mathematics. Taipei, Taiwan, p. 1-43, November 2001. Disponível em: <http://www.fi.uu.nl/publicaties/literatuur/4966.pdf>. Acesso em: 10 jan. 2016.

[6] Heuvel-Panhuizen. Reform under attack - Forty Years of Working on Better Mathematics Education thrown on the Scrapheap? No Way! In: Sparrow, L.; Kissane, B.; Hurst, C. (Eds.). Proceedings of the 33th annual conference of the Mathematics Education Research Group of Australasia. Fremantle: Merga. 2010

[7] Streefland, L. Fractions in Realistic Mathematics Education. Dordrecht: Kluwer, 1991. Unesco. Educação para todos - 0 compromisso de Dakar. Ação Educativa: 2001. 70p. Disponível em: < http://unesdoc.unesco.org/images/0012/001275/127509porb.pdf>Acesso em: 20 jul. 2016.

[8] Widjaja. Y. b.; Heck, A. How a Realistic Mathematics Education approach and microcomputer-based laboratory worked in lessons on graphing at an Indonesian Junior High School. Journal of Science and Mathematics Education in Southeast Asia, Amsterdam, v. 26, n. 2, p. 1-51, 2003. 


\section{Capítulo 9}

\section{A aprendizagem da Matemática: Uma possibilidade para todos}

\section{Carmen Lúcia Giuntini \\ Marlene Silva Rodrigues \\ Valéria de Cássia Gasques Mortari \\ Vanilda Carvalho Mendes}

Resumo: Este relato tem como objetivo apresentar análise do trabalho desenvolvido em formação continuada da área da matemática para professores do Ensino Fundamental da rede municipal de Várzea Grande. As formações acontecem quinzenalmente com início em março e final em outubro de 2019, são realizadas nos horários: matutino, vespertino e noturno. A proposta formativa objetiva propiciar aos professores a realização de um trabalho diferenciado na área de Matemática, fundamentado na discussão e na didatização das habilidades e dos objetos de Conhecimento, contemplados na BNCC e Documento de Referência Curricular para Mato Grosso-DRC, tendo como operacionalização as metodologias ativas. A forma de avaliação adotada para formação foi avaliação prognóstica, onde foi criado um protocolo de caráter formativo. Assim, as formações continuadas buscam contribuir para a qualificação dos profissionais da educação no sentido de apurarem o olhar para o nível de proficiência dos alunos em matemática.

Palavras-chave: Formação; Ensino Fundamental; Matemática. 


\section{INTRODUÇÃO}

A rede municipal de Várzea Grande contempla oitenta e uma Unidades de Ensino, sendo dezenove Centros de Educação Infantil e sessenta e duas Escolas Municipais de Educação Básica atendendo um percentual de vinte e seis mil alunos. Dentro desse universo percebe-se a complexa realidade dos profissionais da Secretaria Municipal de Educação, Cultura, Esporte e Lazer e requer momentos de construção e reconstrução dos seus conhecimentos.

Percebe-se que a fragilidade encontrada por parte dos profissionais que atuam na área de matemática, é que nem todos possuem uma formação especifica da área, muitos são pedagogos e alguns professores dos anos finais possuem a habilitação em Ciências da Natureza, mas sua atuação é como professor de matemática. Isso acaba acarretando problemas de natureza epistemológica, científica e pedagógica. Temos também observado que alguns profissionais da área de matemática trazem consigo uma visão Socializar, valorizar e divulgar experiências de ensino, em diferentes linguagens, caracterizando-se pela diversidade das pesquisas, produções, participação e/ou envolvimento dos professores em projetos educativos em matemática/cultura na escola e em outros espaços, dialogando e articulando o processo de formação;

Promover o diálogo e a troca de experiência entre professores de matemática das redes pública e outras instituições de ensino, proporcionando diferentes oportunidades para apresentar suas práticas, influências nas expressões e manifestações do ser humano que expressa e interpreta o mundo pela matemática (viva, aplicável, relevante, ativa).

\section{PAPEL DO PROFESSOR FORMADOR}

O papel do formador neste momento é de orientar e mediar o fazer pedagógico dos professores das escolas municipais de Várzea Grande. Após algumas investigações e análise dos dados acima mencionados a coordenação pedagógica do Núcleo de Tecnologia Municipal-NTM, juntamente com os formadores passaram a pensar a formação continuada para que o município não só garantisse o acesso, mas a permanência e o sucesso desses alunados da rede municipal. Assim os formadores pensaram sua proposta buscando orientar e mediar os professores através de encontros quinzenais oportunizando a construção de caminhos para a melhoria do ensino do componente de matemática, afim de que os alunos vejam a importância da disciplina de matemática no seu dia a dia. Marcelo Garcia (1999) nos indica os caminhos quando diz que

A formação de professores deve capacitar os professores para um trabalho profissional que não é exclusivamente - ainda que principalmente, ou seja- de aula. [...] Esta é uma perspectiva necessária que tem de incluir como objetivo da formação de professores. [...] A formação de professores não é um processo que acaba nos professores. Ainda que seja óbvio afirma-lo, a qualidade de ensino que os alunos recebem é o critério último- frequentemente inescrutável - para avaliar a qualidade da formação na qual os professores se implicaram, (MARCELO GARCIA, 1999, P.27).

\section{FUNDAMENTOS TEÓRICO-METODOLÓGICOS:}

Esta proposta de formação continuada fundamenta-se na concepção de professor reflexivo, proporcionando espaços de diálogo e reflexão acerca de suas práticas profissionais. Pressupõe o enfrentamento de desafios e a ressignificação dos métodos e currículos escolares, levando o professor a sair da sua "zona de conforto" para que tenha uma postura inovadora e que seja aberto às mudanças reflexiva, ativas e crítica, a fim de que possa repensar sua prática educativa.

De acordo com este contexto a formação de professores nos dias atuais tem se voltado a discutir e problematizar os espaços referentes a esta formação, enfatizando que os professores obtenham informações que vão além do conhecimento obtido na universidade em sua formação inicial, mas numa busca para aprimorar a sua trajetória profissional.

É nessa perspectiva que o processo de Formação Continuada alimenta a construção da identidade pessoal e profissional do professor que trabalha o componente curricular da matemática, visando sempre uma reflexão da prática educativa articulada pelo formador/mediador.

Neste ano será realizada a Prova Brasil/SAEB, pelo Ministério de Educação, diante disso propomos um trabalho diferenciado para professores que atuam com o componente curricular da área da matemática no Ensino 
Fundamental anos iniciais e finais, atendendo as prerrogativas previstas no Plano Nacional de Educação e Plano Municipal de Educação no que refere à oferta de formação de acordo com as metas 18 e 19, por meios de encontros coletivos de reflexão, dialogo, oficinas e troca de experiências.

De acordo com a BNCC, o Ensino Fundamental deve ter compromisso com o desenvolvimento do letramento matemático, definido como as competências e habilidades de raciocinar, representar, comunicar e argumentar matematicamente, de modo a favorecer o estabelecimento de conjecturas, a formulação e a resolução de problemas em uma variedade de contextos, utilizando conceitos, procedimentos, fatos e ferramentas matemáticas. É também o letramento matemático que assegura aos alunos reconhecer que os conhecimentos matemáticos são fundamentais para a compreensão e a atuação no mundo e perceber o caráter de jogo intelectual da matemática, como aspecto que favorece o desenvolvimento do raciocínio lógico e crítico, estimula a investigação e pode ser prazeroso (fruição). (BNCC, p 264.)

Os encontros formativos terão como base as metodologias ativa, em sintonia com as concepções apresentadas na Base Nacional Comum Curricular (BNCC) e no Documento de Referência Curricular para Mato Grosso.

Metodologias ativas, no entender de Moran (2015), está posta onde o discente é sujeito central da aprendizagem, em atividades de grupos e /ou individuais, nos processos de aprendizagem colaborativa e também cooperativa, em aprendizado por experiência, assim como em temas fundamentados em problemas e projetos.

Porém temos outro teórico para embasar o uso de metodologias ativas é John Dewey (1859-1952), filósofo, psicólogo e pedagogo norte-americano que formulou o ideal pedagógico da Escola Nova, no qual a aprendizagem ocorre pela ação (learning by doing), ou do aprender fazendo (BERBEL, 2011.

\section{PROCEDIMENTO METODOLÓGICO}

A dinâmica geral para a efetivação da formação continuada será fortalecida pelas ações conjuntas, pautada no diálogo entre formador e professores da rede municipal de Várzea Grande.

Propomos momentos diferenciados com formação com o grupo, orientações e direcionamento para aplicação em sala de aula.

Com a finalidade de traçar o perfil dos participantes do grupo de matemática do Ensino Fundamental, foram realizados questionamentos investigativos, via internet através do endereço eletrônico formacaosmevg@gmail.com.

As perguntas que nortearam a pesquisa foram: Quantos anos você atua como professor de matemática? Em quais anos do ensino fundamental está atuando? Você se apropriou do Documento de Referência Curricular para Mato Grosso? Dentre as unidades temáticas trabalhadas em matemática, quais as que você gostaria de receber apoio pedagógico? E qual a sua disponibilidade para participar das formações oferecidas pela Secretaria Municipal de Educação, Cultura, Esporte e Lazer/ SMECEL? Se o professor é contratado ou efetivo? Neste questionário foram detectados pontos relevantes para iniciar a formação continuada da rede municipal de Várzea Grande/MT.

Os encontros coletivos acontecem quinzenalmente, com duração de quatro horas em um total de dez encontros, com datas previamente agendadas, ofertadas nos três períodos matutino, vespertino, noturno e ao sábado de acordo com a disponibilidade de tempo do professor, visando que todos tenham acesso as formações.

Os encontros formativos foram distribuídos nos nove anos do ensino fundamental da seguinte forma: de acordo com a etapa de atuação dos professores.

Os cursistas terão a culminância com uma produção de texto que aborde a temática estudada. Também será possibilitada a socialização dos estudos e intervenções formativas desenvolvidas nas escolas, este será um momento de sistematização da teoria e da prática pedagógica entre seus pares. 


\section{BREVE ANÁLISE DA FORMAÇÃo CONTINUADA DA ÁREA DE MATEMÁTICA NO MUNICÍPIO DE VÁRZEA GRANDE}

A formação continuada para professores que trabalham com o componente curricular de matemática foi pensada após a análise dos dados do INEP/IDEB do município de Várzea Grande, onde se constatou baixos índices nas avaliações externas em relação a proficiência que os alunos deveriam apresentar.

Esta formação continuada está voltada para as práticas metodológicas ativas em consonância com a Base Nacional Comum Curricular-BNCC e o Documento de Referência para Mato Grosso-DRC/MT.

No primeiro momento foi realizado questionamento investigativo via internet através do endereço eletrônico formacaosmevg@gmail.com, para definir o perfil dos participantes.

Um ponto relevante do questionamento realizado na pesquisa se refere às cinco unidades temáticas: números, álgebra, geometria, grandezas e medidas, probabilidade e estatística. E obtivemos como respostas dos participantes a necessidade de receberem apoio pedagógico sobre as unidades temáticas, dados estes que as porcentagens apresentam-se da seguinte forma: 11,1\% gostariam de receber apoio em números, $22,2 \%$ em álgebra, $55,6 \%$ em geometria, $44,4 \%$ em grandezas e medidas e $55.6 \%$ em probabilidade e estatística.

Diante do exposto percebemos o gargalo no que tange ao domínio dos docentes que atuam com matemática em relação ao conhecimento das unidades temáticas citadas acima.

Paulo Freire afirma que "não há ensino sem pesquisa e pesquisa sem ensino" (2001, p. 32). Para ele, o educador deve respeitar os saberes dos educandos adquiridos em sua história, estimulando-os a sua superação através do exercício da curiosidade que os instiga à imaginação, observação, questionamentos, elaboração de hipóteses e chega a uma explicação epistemológica. 0 autor destaca ainda, que é necessário refletir criticamente sobre a prática educativa para evitar a reprodução alienada, criando possibilidades para o aluno produzir ou construir conhecimentos: “... ensinar não é transferir conhecimento, mas criar as possibilidades para sua própria produção e a sua construção" (2001, p. 52). Portanto, o professor deve estimular o ato de pesquisar para que o aluno passe a ser sujeito e não apenas objeto da nossa história.

Nesta perspectiva, os encontros de formação continuada em andamento são realizados quinzenalmente, de forma a contribuir para a qualificação dos professores no sentido de que estes possam (re)significar sua prática, estimulados pela reflexão-ação-reflexão.

\begin{tabular}{|c|c|}
\hline \multirow{2}{*}{\multicolumn{2}{|c|}{$\begin{array}{l}\text { PERÍODO DE REALIZAÇÃO } \\
\text { Março a setembro de } 2019\end{array}$}} \\
\hline & \\
\hline \multicolumn{2}{|c|}{ CARGA HORÁRIA } \\
\hline Total do projeto & $44 \mathrm{~h}$ \\
\hline De Matemática & $24 \mathrm{~h}$ \\
\hline Do formador & $44 \mathrm{~h}$ \\
\hline Do CURSISTA & 44 horas \\
\hline
\end{tabular}

\begin{tabular}{|c|c|c|}
\hline 4. PÚBLICO ALVO & $\begin{array}{c}\text { Número de escolas } \\
\text { atendidas }\end{array}$ & $\begin{array}{c}\text { Números de professores } \\
\text { participantes }\end{array}$ \\
\hline $\begin{array}{c}\text { Professores pedagogos que atuam no 2ํㅜㄹo clo e professores } \\
\text { das áreas de Língua Portuguesa, Matemática, História e } \\
\text { Ciências Naturais do 3ํo ciclo, da rede municipal de Cuiabá. }\end{array}$ & $\mathbf{5 3}$ & $\mathbf{1 5 8}$ \\
\hline
\end{tabular}

\section{RECURSOS UTILIZADOS}

Os recursos a serem utilizados são: Documento de Referência do Estado de Mato Grosso, SAEB, livros, revistas eletrônicas, artigos, Internet para pesquisas, estudos e socialização das produções, sendo utilizados equipamentos de informática, multimídia, recursos como som e imagem para dinamizar os encontros e outros materiais didáticos necessários para realização das formações. 


\section{DADOS DA FORMAÇÃO: CONTEÚDOS/TEMÁTICAS TRABALHADAS}

\section{1을 Encontro:}

-Resultado da avaliação externa de matemática: Prova Brasil/SAEB;

-Habilidades do componente Curricular Matemática - Documento de Referência Curricular de Mato grosso.

Nesse primeiro contato com os professores cursistas foi apresentado o resultado das avaliações externas (SAEB) aplicadas em 2017. Através do site QEdu, procuramos sensibilizar os docentes sobre os resultados do município, fazendo um comparativo com os resultados a nível de Brasil e do estado de Mato Grosso. Alguns professores mostraram-se surpresos com o resulta uma vez que desconheciam os dados. Outro fato apresentado que surpreendeu os profissionais foi a apresentação da evolução do aprendizado, onde mostra que de 2015 para 2017 o índice de alunos que aprenderam o adequado permaneceu em 31\%, sem nenhum avanço. Dando prosseguimento, foi apresentado um quadro comparativo das escolas da rede que participaram da avaliação com seus respectivos resultados. Apesar de não termos exposto os nomes das escolas, somente através dos resultados apresentados ficou visível a diferença de índices de alunos que aprenderam o adequado. Tivemos escolas onde os alunos apresentaram níveis de aprendizagem de 10\% e escola com nível de 70\%. Esse trabalho de apresentar os resultados aos professores foi importante porque muitos desconheciam a realidade da rede e da escola em que trabalham. De acordo com as colocações dos cursistas, percebe-se visões diferentes, enquanto que um grupo coloca que o trabalho da escola precisa melhorar, precisam de mais apoio dos gestores, precisam estudar mais, se apropriar dos documentos oficiais, um outro grupo de professores acredita que os resultados apresentados estão ruim porque os pais não ajudam, não são presentes, a escola não oferece material pedagógico, enfim, que o problema não é o que se ensina nem a forma como se ensina.

\section{2o Encontro:}

-Descritores da matriz de Referência de Avaliação de Matemática Prova Brasil/SAEB;

- Simulado de Matemática.

Nesse encontro foi apresentado a matriz de avaliação do SAEB e algumas observações sobre o que mudou na BNCC, como por exemplo os temas da matemática que sofreram algumas alterações na nomenclatura e a mudança que considero mais importante, que foi desmembrar a álgebra do tema números e operações, criando um eixo só para o desenvolvimento do pensamento algébrico desde o $1^{\circ}$ ano. Após esse estudo da matriz, os professores receberam um simulado que preparei, tiveram que resolvê-lo e procurar qual o descritor que contemplava cada questão. Os cursistas apresentaram algumas dificuldades em apontar qual o descritor da questão, justificando que não trabalham dessa forma e alguns até mesmo desconheciam a matriz do SAEB.

\section{3o Encontro:}

-Teoria dos Campos Conceituais (Campo Conceitual aditivo)

Trabalhar situações problemas com os professores é algo muito produtivo porque essa temática é muito popular no dia a dia da escola, faz parte do planejamento e do trabalho dos profissionais, porém os resultados apresentados não são satisfatórios. Apesar de alguns cursistas terem participados da formação do PNAIC, onde foram discutidas as situações problemas embasadas na Teoria dos Campos Conceituais de Gérard Vergnaud, eles já não lembravam e outros nunca ouviram falar. Estudamos várias situações e os respectivos conceitos envolvidos. No decorrer do estudo, conversamos sobre como eles estão trabalhando as situações problemas, a importância de procurar meios que levem os alunos a interpretar, entender o que está sendo posto, desenhar a situação, procurar formas próprias de resolver o problema para só então usar o algoritmo formal. Outro detalhe importante é o momento da socialização, onde os alunos tem a oportunidade de expor como pensou e como resolveu o problema. Os professores concluíram que fazem um trabalho constante de resolução de problemas mas não com esse olhar de que a situação muda dependendo de como aparece a pergunta e de onde está a incógnita do problema, o que os leva a concluir que não devemos trabalhar com palavras chave e sim analisar cada situação. 


\section{Encontro:}

-Teoria dos Campos Conceituais (Campo Conceitual multiplicativo).

O estudo do Campo Conceitual multiplicativo foi bem intenso, cheio de indagações e conflitos, uma vez que os professores colocaram que recebem os alunos com pouca ou sequer nenhuma noção de multiplicação ou divisão. Segundo os cursistas esse trabalho precisa ser melhorado nas séries iniciais porque fica muito difícil receber aluno no $4^{\circ}$ ano sem essa base de conhecimento.

\section{5o Encontro:}

- Oficina de elaboração de itens.

Nessa oficina os professores precisavam reconhecer, compreender e trabalhar com as habilidades de resolução de problema apresentadas nos descritores da Prova Brasil. Eles receberam algumas imagens, enunciados, gráficos, etc, e a partir daí deveriam elaborar itens que contemplavam um determinado descritor. Surgiram muitas dificuldades porque não é algo comum para o professor elaborar questões que estejam de acordo com o descritor apontado, eles trabalham com questões prontas do livro didático ou de simulados encontrados na internet. Os cursistas trabalharam em grupos e o resultado apresentado foi bem interessante, porque mesmo que as questões elaboradas não estivessem contemplando a necessidade exigida pelo descritor, no momento da socialização eles conseguiam perceber os erros e a mudar a maneira de pensar.

\section{6o Encontro:}

\section{- Oficina de Stop Motion.}

Esse encontro teve como objetivo estimular o uso das tecnologias no processo de ensino e aprendizagem e ampliar o letramento digital dos professores. Os profissionais tem muita resistência com as tecnologias e, como justificativa para não usá-la é de que as escolas não possuem laboratórios de informática, não tem acesso à internet, etc. Pensando nesses entraves, propomos aos cursistas um trabalho com o aplicativo de celular Studio Stop Motion. 0 uso desse aplicativo estimula o protagonismo dos alunos uma vez em que eles passam a ser autores de vídeo animação. Os alunos precisam fazer um roteiro da história, produzir cenário, fotografar, editar, enfim, são várias etapas de trabalho até a conclusão, que proporcionam o ensino de diversos conceitos, atitudes e procedimentos, envolvendo vários componentes curriculares. Os professores foram muito participativos, acharam fácil usar o aplicativo e se mostraram-se animados para usá-los na escola.

\section{AVALIAÇÃO}

A avaliação será prognóstica e posta no decorrer do processo de formação, terá o cunho diagnóstico, atrelada ao planejamento a fim de que seja um instrumento nas ações-reflexões-ações. Avaliação não pode ser delimitada em espaços devido ao seu processo dialético e continua. Neste sentido "todo o trabalho pedagógico direciona-se á busca de novos conhecimentos [...] mediar à experiência educativa significa acompanhar o aluno em ação-reflexão-ação" (HOFFMANN, 2009, P. 91-92).

A função da avaliação é identificar as melhorias, determinando também quanto e em que nível os objetivos estão sendo atingidos. Tem em si a tarefa de ser diagnóstica formativa e somativa, ser um instrumento dialético do avanço, um instrumento da identificação de novos rumos. Para isso, é necessário o uso de instrumentos adequados, com critérios estabelecidos e dados fidedignos e reais. Para que a avaliação seja real, faz-se necessário que detenha o máximo possível de informações em relação às ações desenvolvidas.

Ao final da formação, foi realizada uma avaliação e os professores fizeram os seguintes apontamentos:

\section{ASPECTOS POSITIVOS:}

- A partir da formação a matemática passa a ser vista com um novo olhar;

- $\quad$ É uma formação que de fato está fazendo a diferença;

- $\quad$ Formação que contribui significativamente no fazer pedagógico; 
- $\quad$ As atividades do curso foram usadas em sala de aula;

- Trocas de experiências;

- A formação está me ajudando a sanar algumas dúvidas que trago do ensino médio;

- As atividades desenvolvidas facilitam meu trabalho em sala de aula;

- $\quad$ Formação dinâmica;

- Curso onde não ficamos só na teoria, estudamos a teoria e vemos a prática;

- Me sinto auto motivada com as formações;

- $\quad$ Aprendi a trabalhar com atividades lúdicas;

- Aulas proveitosas onde podemos ampliar nossas ideias e metodologias;

\section{ASPECTOS A SEREM MELHORADOS:}

- Professores que chegam atrasados e atrapalham a formação;

\section{SUGESTÕES:}

- Grupos menores de cursistas (turma de sábado);

- Mais encontros formativos;

- Encontro para explicar como ensinar divisão para os alunos;

- Mais encontros para ensinar como preparar aulas usando os descritores;

- Estudar os descritores aprofundando nos conceitos;

- Substituir o Espaço de Saberes que acontece na escola pelo curso;

- Encontro semanal.

\section{CONSIDERAÇÕES FINAIS}

Com a execução das formações/oficinas, acreditamos estar contribuindo na ampliação do conhecimento dos profissionais da Educação acerca das questões relacionadas ao fazer matemático, bem como provocar estes profissionais a refletir e repensar sua ação pedagógica, possibilitando mudanças na prática diária por meio de atividades inovadoras e diversificadas, que fortaleçam e solidifiquem a proficiência nas escolas da rede municipal. Pretendemos também neste trabalho, chamar a atenção para a importância do currículo escolar como um conjunto de articulação de saberes significativos à realidade dos alunados, e que este é um instrumento poderoso que pode subsidiar na construção de uma identidade protagonista desse aluno.

Para a formação inicial e continuada é preciso decisões políticas que reflitam de fato no campo educacional, pois quando atendida nas dimensões necessárias, multiplica-se em possibilidade de ascensão social.

\section{REFERENCIAS:}

[1] Brasil. MEC. Base Nacional Comum Curricular - Bncc do Ensino Fundamental. Disponível em: Acesso em: 19 de abr. de 2018.

[2] Brasil. Matemática: Orientações para o Professor, Saeb/ Prova Brasil, 4⿳亠丷a série/ 5o ano, Ensino F. - Brasília: Instituto Nacional de Estudos e Pesquisas Educacionais Anísio Teixeira, 2009.

[3] Berbel, Neusi Aparecida Navas. As metodologias ativas e a promoção da autonomia de estudantes. Semina: Ciências Sociais e Humanas, Londrina, v. 32, n. 1, p.25-40, jan./jun. 2011. Semestral. Universidade Estadual de Londrina. http://dx.doi.org/10. 5433/1679-0359. Disponível em: http://www.uel.br/revistas/uel/index. php/seminasoc/article/view/10326/10999. Acesso em: 15 fev. 2017. 
[4] Dewey, J. Como Pensamos: Como se relaciona o pensamento reflexivo com o processo educativo: uma reposição. São Paulo: Companhia Editora Nacional, 1959.

[5] Hoffmann, Jussara, Avaliar para promover: as setas do caminho. Porto Alegre: Mediação, 2009.

[6] Marcelo Garcia, C. Formação de professores: para uma mudança educativa. Portugal: Porto Editora, 1999.

[7] Moran, J. M. Mudando a educação com metodologias ativas. In Convergências Midiáticas, Educação e Cidadania: aproximações jovens. Coleção Mídias Contemporâneas

ANEXOS:

\section{AVALIAÇÃO DOS CURSISTAS:}

Na avaliação realizada pelos cursistas, ao final da formação, os professores fizeram os seguintes apontamentos acerca dos critérios abaixo:

\section{AVALIAÇ̃̃O DA FORMAÇ̃̃O DE MATEMÁTICA}
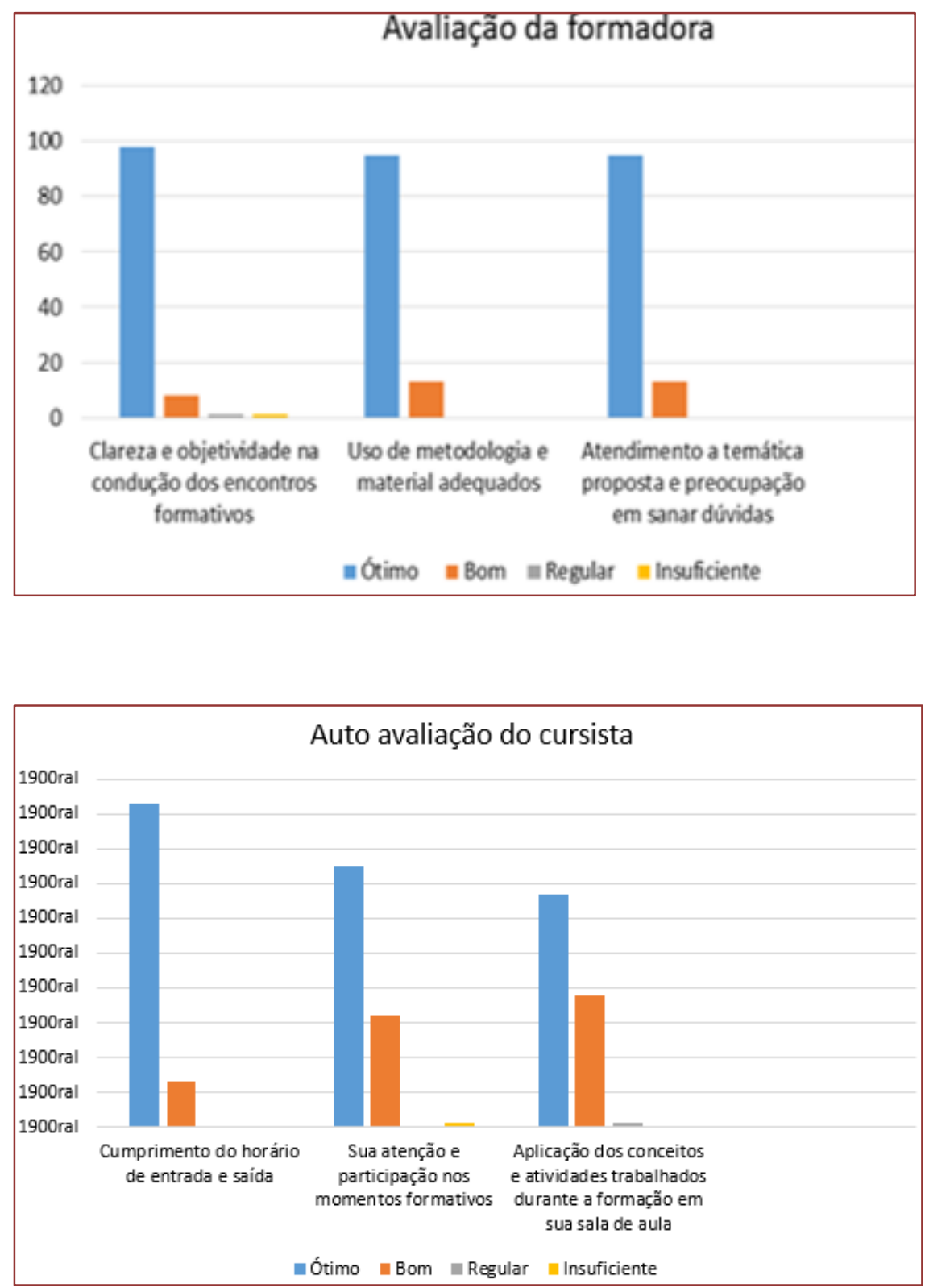


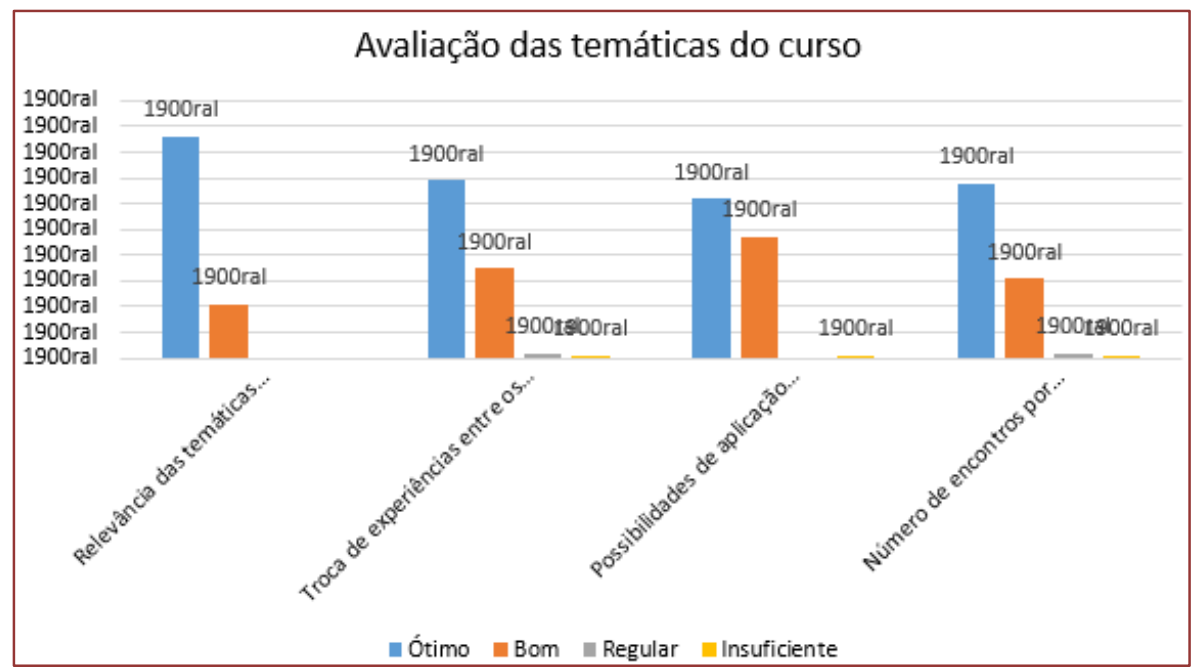

Além da avaliação objetiva, os professores tiveram a oportunidade de relatar os aspectos positivos, os aspectos a serem melhorados e contribuir com sugestões para as próximas formações.

\section{Anexos}

Encontro de Formação com professores que atuam nos Anos Iniciais do Ensino Fundamental do municipio de Varzea Grande-MT.

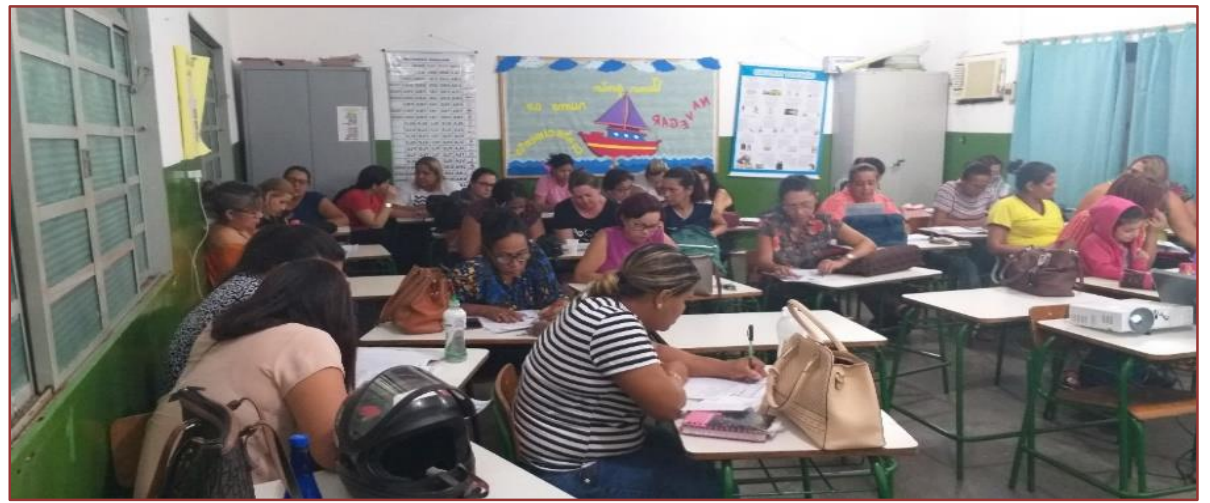

Encontro de Formação com professores que atuam nos Anos Iniciais do Ensino Fundamental do municipio de Varzea Grande-MT.

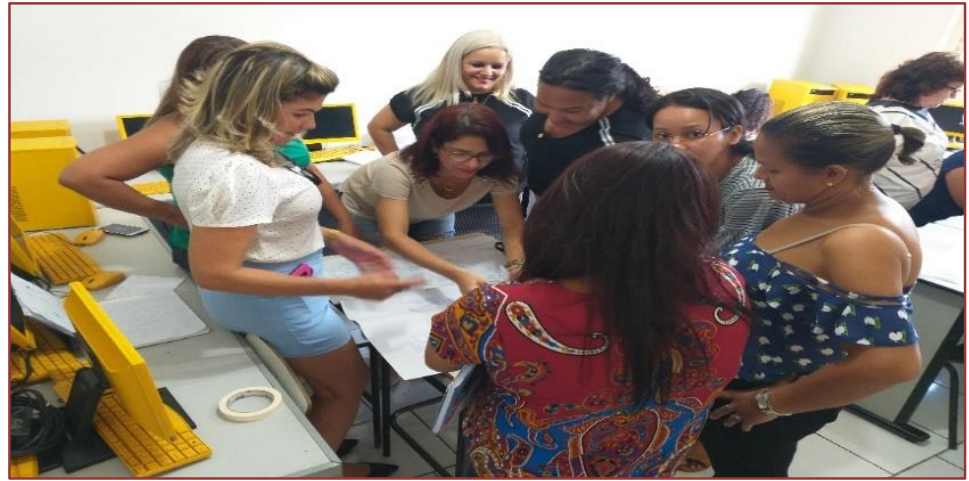


Encontro de Formação com professores que atuam nos Anos Iniciais do Ensino Fundamental do municipio de Varzea Grande-MT.

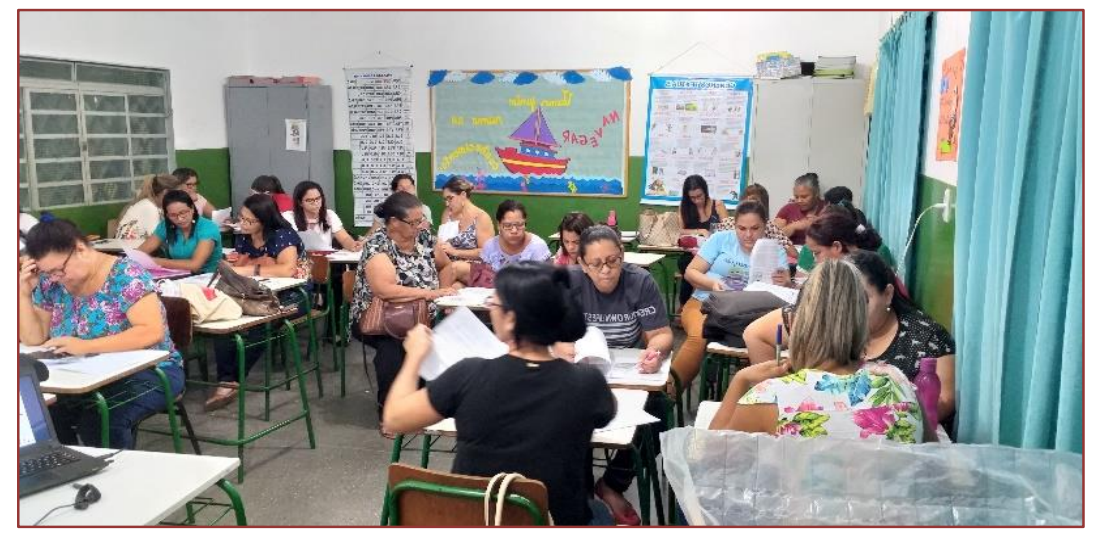

Encontro de Formação com professores que atuam nos Anos Iniciais do Ensino Fundamental do municipio de Varzea Grande-MT.

(Oficina de Stopmotion)

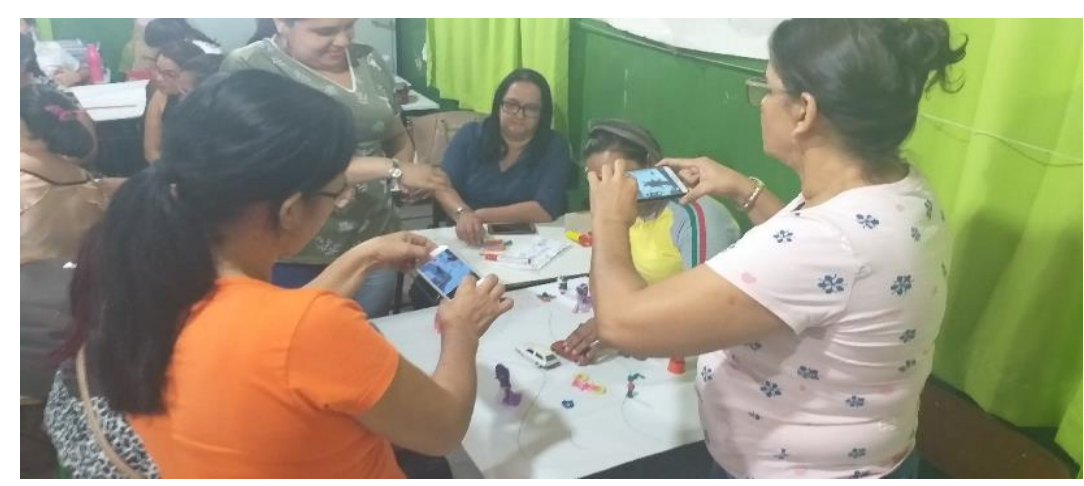




\section{Capítulo 10}

A criação da régua de números inteiros adaptada para o Braille a partir da modificação do material dourado

\section{Douglas Lopes do Nascimento \\ Lenilson Oliveira do Nascimento \\ Lauro Lopes Pereira Neto \\ Camila Lima da Costa}

Resumo: Este trabalho é fruto das inquietações de professores quanto ao ensino de alunos com deficiência visual: como ensiná-los? Como incluí-los em sala de aula? Essas inquietações podem ser normais, visto que os cursos de formação inicial não dão conta de supri-las. Propõe-se então, a construção de um material didático manipulável como proposta didática para o ensino de pessoas com deficiência visual, que auxilia no processo de aprendizagem dos alunos com deficiência visual. 0 objetivo deste estudo foi propor a criação da régua de números inteiros adaptada para o Braille, a partir da modificação do material dourado intencionando contribuir na compreensão do conjunto dos números inteiros. Trata-se de um Material Didático Manipulável, de baixo custo que auxilia no processo de inclusão de alunos com deficiência visual em sala de aula, buscando dar sentido aos conceitos relacionados aos números inteiros. Utilizou-se uma metodologia de cunho qualitativa e experimental, bem como, bibliográfica.

Palavras-chave: Ensino de Matemática; Material Didático Manipulável; Inclusão; Deficiência Visual. 


\section{INTRODUÇÃO}

Diante das constantes inquietações de professores em lecionar matemática a alunos com deficiência visual, devido a sua falta de qualificação para atender a tais alunos, percebeu-se a necessidade de criar um material didático que garanta a eficácia do processo de ensino e aprendizagem, de forma a superar as metodologias de ensino tradicionais e propiciar metodologias que promovam a aprendizagem dos estudantes, em especial, dos alunos com deficiência visual. A partir disto, deram inícios alguns estudos para que possibilitasse a criação de um novo material.

Desta forma, buscou-se identificar inicialmente como está regulamentado o ensino para pessoas com deficiência visual no Brasil e em Alagoas, apresentando de forma cronológica a História da Educação para pessoas com deficiência visual no Brasil, enfatizando que as leis dão direitos e garantias à educação para as pessoas com deficiência visual.

Como proposta metodológica propôs-se desenvolver um material manipulável que auxiliasse aos professores no ensino do conceito de números inteiros negativos, para alunos com deficiência visual. A necessidade de suprir as deficiências didáticas ao trabalhar com adolescentes com deficiência visual, despertou-se a necessidade de criar a proposta da régua de números inteiros adaptada para o Braille, a partir da modificação do Material Dourado, um material auxiliar ao processo de ensino/aprendizagem de matemática.

A proposta de se pensar materiais adaptados ao ensino de cegos surgiu a partir das experiências e vivências dos próprios autores deste trabalho. Ainda como graduandos em Licenciatura em Matemática, estes participaram do Estágio Supervisionado VI em Educação Especial, ofertado pelo Instituto Federal de Alagoas, que por opção dos mesmos, escolheram trabalhar com deficientes visuais ${ }^{12}$. Foram as vivências da docência, isto é, as dificuldades enfrentadas na docência de matemática para adolescentes com deficiência que despertaram a necessidade de se pensar metodologias utilizando-se de Materiais Didáticos Manipuláveis (MDM’S) como recurso metodológico.

Portanto, o foco principal deste estudo foi evidenciar o uso de um Material Didático Manipulável (MDM), a régua de números inteiros adaptada para o Braille, como ferramenta metodológica indispensável ao processo de ensino e aprendizagem dos alunos, deficientes visuais ou não.

\section{O ENSINO PARA PESSOAS COM DEFICIÊNCIA VISUAL EM ALAGOAS: POLÍTICAS E MARCOS LEGAIS}

A Educação Especial no Brasil começou a se estruturar no século XIX, quando surgiram os primeiros serviços especializados dedicado a pessoas com deficiência. 0 atendimento a esta população era prestado por instituições educacionais específicas, voltadas para o abrigo, a assistência e a terapia. (MACEIÓ, 2016).

Em 1854, foi fundado o Imperial Instituto dos Meninos Cegos e em 1856 o Imperial Instituto dos SurdosMudos, tais consistiam em instituições governamentais que tratavam da educação escolar das pessoas cegas e surdas-mudas. No século XIX, apenas os cegos e surdos eram contemplados com a ação relacionada à educação e tal ação concentrava-se apenas na capital imperial que na época, localizava-se no Rio de Janeiro.

O Instituto Imperial dos Cegos foi criado através do decreto imperial no 1.428 de 1854 que dava o direito as pessoas deficientes visuais a estudarem, os artigos 19, 20 e 21 estabeleciam o número de vagas para bolsistas, além de fornecer o valor a ser pago para os não cotistas (BRASIL, 1854):

Art. 19. 0 numero de alumnos não excederá de 30 nos tres primeiros annos. Neste numero se comprehendem até 10 , que serão admittidos gratuitamente, quando forem reconhecidamente pobres. Art. 20. A estes o Governo fornecerá sustento, vestuario, e curativo. Art. 21. Os que não forem reconhecidamente pobres pagarão ao Estabelecimento huma pensão annual arbitrada pelo Governo no principio de cada anno, a qual não poderá exceder de $400 \$ 000$, alêm de huma joia no acto da entrada até $200 \$ 000$, marcada pela mesma fórma.

Mas, foi apenas em 1958 que em Alagoas surge a primeira política direcionada ao ensino público especial com a oferta de escolarização aos deficientes mentais. Só em 1973 é criada na Secretaria Estadual de

\footnotetext{
12 Deficiente Visual compreende aos sujeitos que possuem pequenas alterações na acuidade visual até a ausência da percepção da luz (LAPLANE; BATISTA, 2008, p.210).
} 
Educação, a Diretoria de Educação Especializada que passou a conduzir a Educação Especial no estado de Alagoas (ALAGOAS, 2005).

Contudo, a incorporação da Educação Especial nas políticas e ações governamentais não modificou o modelo assistencialista das instituições educacionais do século XX. Desta forma, nos anos de 1970 e 1980 , prevaleceu a concepção de que a formação escolar das pessoas com deficiência, deveria ocorrer em um mundo à parte (MACEIÓ, 2016).

Houve então, a necessidade de criar escolas que pudessem atender pessoas com necessidades especiais. Com essa perspectiva foi criada a Escola de Cegos Cyro Accioly, através do decreto no 2.794 de 15 de junho de 1976 e, apenas no ano de 1985, são implantadas as primeiras salas especiais no interior do estado de Alagoas nas áreas de deficiência mental, auditiva e visual, todas de caráter assistencialistas.

Anos depois, em 2016, surge a resolução №. 01/2016 - COMED / MACEIÓ que é o Conselho Municipal de Educação de Maceió e estabelece normas para a educação especial, em uma perspectiva na educação inclusiva com relação ao atendimento especializado aos estudantes com deficiência, transtornos globais e altas habilidades/superdotação, assegurando o acesso destes nas modalidades de ensino da Educação Básica pública e privada a qual pertença ao Sistema Municipal de Ensino de Maceió / Alagoas.

Assim, a proposta pedagógica das instituições de ensino do município de Maceió foi assegurada de forma a atender às necessidades especiais dos alunos. Isto é, a escola adapta-se às necessidades dos alunos. Com isso, garantindo um processo de ensino e aprendizagem justo, democrático e inclusivo.

É muito importante citar que a resolução buscou garantir o atendimento especializado ao estudante nas escolas públicas municipais, bem como a obrigação do município em garantir a formação de professores especializados na área. Em seu artigo 6º , afirma:

\section{$\S 2^{\circ}$ A Educação Especial deve garantir serviços voltados a eliminar as barreiras que possam obstruir o processo de escolarização dos estudantes com deficiência, transtornos globais do desenvolvimento e altas habilidades/superdotação, como: \\ I - Cursos de formação para professores de classe comum, do Atendimento Educacional Especializado e demais profissionais da Educação Especial para o atendimento às necessidades educacionais dos estudantes com deficiências, transtornos globais do desenvolvimento e altas habilidades/superdotação; (Maceió, 2016)}

Nesse sentido, a Educação Especial deve garantir serviços que eliminem as barreiras da inclusão no processo de escolarização dos estudantes com deficiência. Para isso, a importância da formação continuada de seus funcionários, isto é, qualificá-los, especializá-los é imprescindível para garantir uma formação justa, democrática e inclusiva.

Além disso, o processo de formação continuada surge a partir do pressuposto que os processos educacionais estão em constante mudança e isso faz com que tenhamos a necessidade de nos manter sempre atualizados no que se diz respeito às práticas educacionais.

Portanto, as leis e decretos discutidos garantem os direitos às pessoas com necessidades especiais, sejam elas físicas ou não, pois garantem acessibilidade e dão a garantia, no campo administrativo, de um ensino de qualidade. Entretanto, para que a inclusão seja efetivada é necessário que estas políticas educacionais não fiquem apenas no campo conceitual, teórico, mas adentrem na prática escolar. Desta forma, passaremos a ter, então, um processo de inclusão, no sentido de que se deve incluir para que haja a garantia do ensino e aprendizagem de qualquer indivíduo.

- Alunos com Deficiência visual em Maceió, relação integração x inclusão.

No estado de Alagoas, uma das importantes instituições que contribuem para a inclusão de pessoas com deficiência visual no meio escolar é a Escola Estadual de Cegos Cyro Accioly, uma vez que esta escola funciona como complementar e suplementar da rede regular de ensino.

A Escola Estadual de Cegos Cyro Accioly, que atualmente está em um momento de transição para Centro Educacional de Cegos Cyro Accioly constitui como um centro de apoio e não uma escola regular propriamente dita, ou seja, o aluno deve comparecer apenas no contraturno da instituição a qual deve estar devidamente matriculado no ensino regular. 
Segundo Plaisance (2015) o paradoxo que existe com relação a escolarização de crianças deficientes em turmas especiais, em estabelecimentos comuns era definida como uma integração "coletiva", ou seja, o aluno é inserido em sala de aula, mas não faz parte do contexto dela com relação a sua aprendizagem.

Plaisance (2015) reitera também dizendo que a educação pautada na integração é tão somente a instauração de uma cultura que visa a educação de forma decorativa, fazendo com que o foco, a aprendizagem destes alunos, seja meramente decorativo, desconexo do aprender.

Vale ressaltar ainda que o termo educação especial vem como um fator separatista, no sentido de falar que um grupo de pessoas está em uma determinada educação especial em meio as pessoas "normais" não os fazem ser seres inclusos, mas sim exclusos pelos próprios termos utilizados.

Dessa forma, a educação inclusiva torna-se uma cultura de acolhida, no sentido das diferenças que todos os seres humanos possuem e do compartilhamento das dependências, pois faz com que os alunos percam a ideia separatista que o ensino especial carregava. Diante disso, a palavra inclusão traz consigo seu significado de incluir e faz com que os alunos façam parte do ensino de uma forma integral, ou seja, o aluno melhora seu aprendizado pelo fato de estar incluso não apenas em sala de aula, mas também estará incluso dentro de um grande contexto que a sala de aula carrega.

\section{- $\quad 0$ ensino de Matemática para deficientes visuais}

É comum ver professores ao ter o primeiro contato com alunos deficientes visuais em suas salas de aula, indagarem: Como ensinar um aluno com deficiência visual? Como incluí-lo em sala de aula? Essas inquietações que surgem podem ser consideras normais, visto que, é um desafio novo para um professor, que ensinava apenas alunos videntes, interagir com alunos com deficiência visual. Entretanto, apesar do professor não estar preparado para trabalhar com alunos com esta deficiência é necessário que ele não se abstenha de seu papel docente, que é o de criar possibilidades para que o seu aluno aprenda.

Fazendo referência a essa questão é relevante perceber que para se trabalhar com alunos com deficiência visual é preciso:

[...] primeiramente compreender que a deficiência visual engloba uma variedade de condições orgânicas e sensoriais que têm consequências diferentes no desempenho visual dos sujeitos. A deficiência visual compreende desde pequenas alterações na acuidade visual até a ausência de percepção de luz, mas as alterações que têm implicações mais sérias para a vida das pessoas com necessidades especiais e para as suas famílias são a baixa visão e a cegueira." (LAPLANE e BATISTA, 2008, p. 210).

Nessa direção é necessário compreender o que é a deficiência visual para que o processo de interação entre alunos e professor possa ser facilitado. No momento em que se entende o que é a deficiência visual e as suas características, desenvolve-se a compreensão de que esta limitação ocorre apenas na visão e não na estrutura cognitiva do aluno.

Uma vez comprometido o campo visual, um aluno com deficiência visual irá adquirir sua aprendizagem por meio de outros sentidos, principalmente o tato. "O toque é um estímulo sensorial indispensável para o desenvolvimento" (LAPLANE e BATISTA, 2008, p. 214). Então, se os alunos com deficiência visual aprendem pelo tato, pelo estímulo sensorial, faz-se necessário que o professor faça uso de materiais concretos para que assim, facilite a aprendizagem. Por essa razão,

O uso correto de materiais concretos na sala de aula, principalmente nas aulas de matemática - disciplina de padrões e formas - configura uma excelente oportunidade do aprendiz cego vivenciar situações corriqueiras, adquirindo informações que podem enriquecer o seu acervo de conhecimento (ULIANA, 2003, p. 02).

Portanto, intencionando contribuir na aprendizagem para o aluno cego é relevante que o professor readapte suas metodologias de ensino para que assim possa incluir o aluno verdadeiramente em sala, fazendo uso de materiais que possam enriquecer os conhecimentos obtidos pelos alunos cegos.

0 desenvolvimento de atividades que viabilizem o processo de ensino e aprendizagem para o aluno é indispensável, pois segundo (Costa, Silva e Pereira Neto, 2013, p. 05): 
Na preocupação da forma de aprendizagem significativa de alunos cegos, há que se considerar que, para a formação apropriada de uma imagem mental dos objetos e conceitos geométricos, a utilização de recursos didáticos manipuláveis vem a ser primordial.

Assim, o professor tem a chance de possibilitar ao aluno o ensino que lhes é de direito e a aprendizagem que passa a ser consequência de um bom trabalho desenvolvido em sala de aula.

\subsection{MATERIAL DOURADO E SUA FORMA DE REINVENTAR O ENSINO DE NÚMEROS INTEIROS COM DEFICIENTES VISUAIS.}

Com a inserção de estudantes com deficiência visual em classes regulares de ensino, o professor vem sendo desafiado a criar formas diferenciadas de alcançar o aprendizado dos alunos e com isso, incluí-los no processo de ensino/aprendizagem.

Criamos, então, a régua de números inteiros e a adaptamos para o Braille utilizando uma tábua de madeira planificada, inicialmente representamos o zero com um pedaço de cano serrado, pois era o material que tínhamos ao nosso dispor naquele momento, em seguida, utilizamos os cubinhos (unidades) do material dourado para poder montar as unidades. Partindo do centro (zero) utilizamos dez unidades, (números de 1 a 10) tanto para a esquerda, representando os números inteiros negativos, quanto para a direita, representando os números inteiros positivos. Optou-se inicialmente em por apenas os sinais de negativo, uma vez que tínhamos pressa em suprir aquela necessidade de aprender dos adolescentes.

Posteriormente, tivemos a ideia de acrescentar nesse material o Braille que é o sistema de escrita dos deficientes visuais para que o material estivesse realmente modificado para os deficientes visuais. 0 processo de elaboração do material pode ser observado na figura 1.

Figura 1 - Criação e utilização da Reta Numérica adaptada ao Braille.

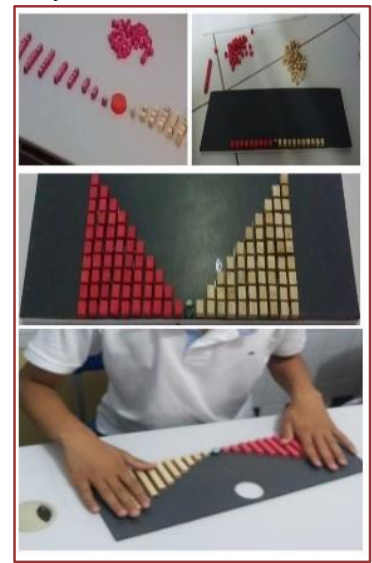

Fonte: acervo do autor

Após a construção do material e feita as devidas modificações consideraram, necessário aplicar o material com os alunos no intuito de experimentar o funcionamento do material e para tal utilizamos o ensino de número sucessor, antecessor e comparação de números.

Figura 2 - Material Dourado Modificado para o Braille

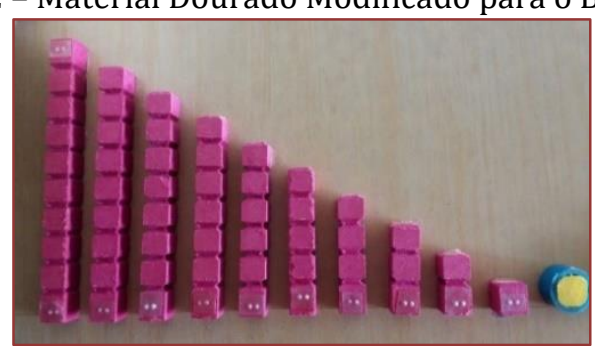

Fonte: acervo do autor 
É importante deixar claro que os autores tiveram a ideia de transpor a régua inteiramente para o Braille, mas naquele momento enquanto alunos de graduação e entendendo todas as dificuldades quanto a materiais e o custo para tal, achou então necessário criar um protótipo que é o apresentado nas imagens 1 e 2. Posteriormente serão feitas as modificações direcionando o material todo para escrita Braille, sem o uso do material dourado, para que assim nossa ideia esteja concreta.

Após criado o material, iniciou-se as aplicações entregando o material por vez a cada um dos 3 adolescentes que frequentavam a aula, destacando que duas tinham dificuldade particulares (dificuldades em operar adição e subtração) e outra era mais rápida no uso das operações básicas, sendo elas adição e subtração. Uma das adolescentes que tinha um pouco de dificuldade em somar e subtrair nos questionou com relação aos espaços em nosso Material Didático Manipulável, segundo ela, os espaços eram pequenos. As adolescentes acharam diferente ao tocar e falaram: "parece uma régua só que com peças" em forma de cubo coladas a uma superfície de madeira.

A partir deste questionamento, nos dirigimos ao professor de escrita Braille para relatar o caso e ouvir a opinião dele sobre estes espaços se eram adequados ou não. Segundo o professor, os espaços estavam adequados ao braile e a dificuldade da criança consistia em não ter uma habilidade tátil adequada. Segundo o professor de Braille, que também é deficiente visual, "o material está bom, porque contribuirá para a criança aperfeiçoar o seu tato". Destarte, constatamos nossa desconfiança no sentido de que o material tira a criança de sua zona de conforto, pois além de proporcionar um melhor aprendizado com relação as operações de adição e subtração no conjunto dos números inteiros, também instiga o aluno a treinar a sua sensibilidade tátil, que é aperfeiçoar sua sensibilidade com relação ao toque que serve para sua escrita braile.

Diante da aplicação do material, os alunos começaram inicialmente a conhecer o material tocando-o, em seguida foram questionados com relação a comparação de números, no sentido de porquê o número 2 é maior que o número 1, ficando fácil do aluno responder que é pelo fato de o número 2 ter uma unidade de peça a mais que o número 1 . Os alunos ficaram maravilhados com o material e ao mesmo tempo estranhando por ser algo diferente de tudo que já viram até aquele momento. Gradativamente partiu-se para os questionamos com relação as operações.

Em seguida, foi introduzido a ideia de um número negativo dando exemplos de decréscimo. Prontamente os alunos entenderam que um número negativo é referente a algo que há perda como, por exemplo, os juros cobrados no banco e o dinheiro que se deve na cantina da escola.

Diante disso, começou a introduzir as operações de adição e subtração no conjunto dos números inteiros fazendo questionamentos básicos como, por exemplo, quanto era dois (2) menos três (-3) e pedíamos para que fizessem esta conta com o auxílio da Reta Numérica adaptada ao Braille, e eles a fizeram com facilidade, fazendo a utilização apenas do tato quando andam duas casas para o lado positivos e retrocedem três casas, nos resultando menos um (-1).

Após a aplicação percebeu-se que o material estava dando sentido aos conceitos utilizados naquele momento (conceito de número negativo), pois ficou claro que o aluno se apossou do conceito de decréscimo, a qual atrelamos inicialmente a um número negativo dentro das operações básicas. Lorenzato (2006, p 34) afirma que "[...] com o auxílio de MD"13, o professor pode, se empregá-lo corretamente, conseguir uma aprendizagem com compreensão, que tenha significado para o aluno [...]".

Vale destacar ainda, a posição do professor para com o material proposto. A partir dos relatos do professor de Braille da instituição que tem experiência de 22 anos de sala de aula, sendo 17 anos como professor de pessoas com deficiência visual e é também deficiente visual, ele nos disse: "o material aqui proposto é novo e muito relevante, pois facilita o entendimento do aluno na linguagem tátil".

Para os deficientes visuais a forma de se ver o material é diferente, segundo o professor de Braille: "as pessoas que enxergam já têm os materiais que utilizam a tinta (impressos) e bem explícitos, já os deficientes visuais necessitam de um material didático" como a reta numérica criada em alto relevo, apresentada pelos estagiários na época.

O material didático faz com que a compreensão seja real no sentido de que para direita da origem (zero) os números são positivos e para esquerda da origem (zero) os números são negativos, isso facilita o processo de aprendizagem, porque os deficientes visuais têm os pontos realçados na reta apresentada,

13 MD é a abreviatura utilizada pelo autor para Material Didático. 
cada número que será identificado facilita o entendimento de que existem números positivos e números negativos.

Ainda segundo o professor de Braille: "muitos Deficientes Visuais não sabem como é que faz com o número negativo". Tais dúvidas foram perguntas que chegam constantemente ao professor: "O que é? Como se faz?". Com a criação da régua, "irá facilitar a aprendizagem dos alunos, de forma a trazer respostas para tais questionamentos”, pois no cálculo, ele vai saber qual operação deve fazer para responder a pergunta: um menos dois $(1-2=-1)$.

A partir dessas experiências e depoimentos, percebemos o potencial de nosso material para ser utilizado não apenas com deficientes visuais, mas também com adolescentes do ensino regular, pois nesse momento acabamos de criar um Material Didático Manipulável (MDM), então decidimos pintar todo lado negativo da reta numérica de vermelho para representar os números negativos e por consequência diferenciar dos positivos que deixamos sem pintar.

\section{CONSIDERAÇÕES FINAIS}

Esta pesquisa nos evidenciou a importância de buscar materiais e metodologias de ensino que melhor se adequem a uma determinada realidade que venhamos a nos deparar futuramente. A criação do Material Didático Manipulável adaptado ao Braille, mostrou-se como um potente instrumento de ensino.

Entendemos que, pesquisar sobre a importância dos materiais manipuláveis para compreensão do que os alunos consideram difícil em sala de aula torna-se imprescindível, uma vez que o professor busca referências para fortalecer as atividades que auxiliam o processo de ensino e aprendizagem dos assuntos trabalhados em sala, dentre eles, sistema de numeração decimal posicional e dos métodos para efetuar as operações fundamentais (ou seja, os algoritmos, dando destaque especial na compreensão de conceitos em curso).

Trouxemos o Material Didático Manipulável como proposta didática, visto que é um material de fácil manuseio por parte do professor e do aluno além, de um material de baixo custo uma vez que pode ser confeccionado pelo próprio professor da instituição de ensino. Desta forma, o Material Didático proposto faz com que os alunos deficientes visuais sejam realmente incluídos em sala de aula, pois o aluno passa não apenas a estar fisicamente em sala, mas sim passa a fazer parte da sala de aula, participando das atividades e entendendo o assunto propostos.

É de grande importância pensar em uma formação acadêmica inicial e continuada para os professores atuantes ou que irão atuar na área no intuito de trabalhar as metodologias no ensino da matemática de forma diversificada, uma vez que em sala de aula as situações com relação aos assuntos ministrados são diversas. Mais relevante ainda é atrelar os MDM's a formação no sentido de formar (cursos de graduação) e aperfeiçoar (formação continuada) professores para que possam dar mais qualidade ao ensino de matemática.

Destarte, no processo de ensino de matemática, torna-se necessário compreender a complexidade da atuação docente com o aluno especial antes de culpabilizá-lo pela não aprendizagem do aluno, pois o processo de ensino e aprendizagem está além da relação professor (ensinar) e aluno (aprender), mas sim depende das condições estruturais da escola, no sentido de uma melhor acessibilidade para o aluno, bem como proporcionar ações formativas para o professor, no sentido de promover o aperfeiçoamento tanto quanto as suas práticas pedagógicas, quanto as escolhas dos materiais pedagógicos e metodológicos utilizados em sala, seja para o ensino regular ou especial.

\section{REFERÊNCIAS}

[1] Alagoas, Plano Estadual De Educação Pee 2006/2015. Disponível em<http://www.educacao.al.gov.br/component/jdownloads/send/131-pee-2016-2015/354-pee-20062015? option=com_jdownloads $>$ acesso em 01 de set de 2018.

[2] Alagoas, Plano Estadual de Educação Pee 2006/2015. Disponível em<http://www.educacao.al.gov.br/component/jdownloads/send/131-pee-2016-2015/354-pee-20062015? option=com_jdownloads $>$ acesso em 01 de set de 2018.

[3] Brasil, Decreto 1428 de 12 de setembro de 1854. Disponível em <http://www2.camara.leg.br/legin/fed/decret/1824-1899/decreto-1428-12-setembro-1854-508506publicacaooriginal-1-pe.html> acesso em 31 de agosto de 2018. 
[4] Brasil, Ministério da Educação. Lei de Diretrizes e Bases da Educação Nacional 9394/96. Disponível em: <http://portal.mec.gov.br/seesp/arquivos/pdf/lei9394_ldbn1.pdf> acesso dia 01 de set. de 2018.

[5] Brasil. Constituição (1988). Constituição da República Federativa do Brasil. Brasília, DF, Senado, 1998.

[6] Brasil, Ministério da Educação. Política Nacional de Educação Especial na Perspectiva da Educação Inclusiva (2008). Disponível em: <http://portal.mec.gov.br/index.php?option=com_docman\&view=download\&alias=16690politica-nacional-de-educacao-especial-na-perspectiva-da-educacao-inclusiva-05122014\&Itemid=30192> acesso em 10 de set. de 2018.

[7] Brasil, Decreto 1428 de 12 de setembro de 1854. Disponível em <http://www2.camara.leg.br/legin/fed/decret/1824-1899/decreto-1428-12-setembro-1854-508506publicacaooriginal-1-pe.html> acesso em 31 de agosto de 2018.

[8] Brasil. Ideb - Índice de Desenvolvimento da Educação Básica. Disponível em: <http://ideb.inep.gov.br/resultado/>. Acesso em 10 set. de 2018.

[9] Brasil. Ministério da Educação. Secretaria da Educação Fundamental. ParâmetrosCurriculares Nacionais: Matemática. Brasília: Mec/Sef, 1997.

[10] _ _. PCN+ Ensino Médio: Orientações Educacionais Complementares aos Parâmetros Curriculares Nacionais. Brasília: Ministério da Educação / Secretaria de Educação Média e Tecnológica, 2002. Disponível em <http://portal.mec.gov.br/seb/arquivos/pdf/CienciasNatureza.pdf pdf> Acesso em: 23 nov. 2018.

[11] Correia, Sério Ferreira. Tábua de pitágoras e a configuração retangular: uma proposta para o ensino do campo multiplicativo para deficientes visuais. (Monografia em Licenciatura Matemática) - Instituto Federal de Alagoas. Alagoas, 2018.

[12] Costa, C. L.; Silva, A. T. A.; Pereira Neto, L. L. Concepções de professores sobre a utilização de materiais manipuláveis no ensino e aprendizagem da geometria para alunos cegos. VII Colóquio Internacional São Cristóvão/SE/Brasil. "Educação e Contemporeidade". 2013.

[13] Laplane, Adriana Lia Friszman de; Batista, Cecília Guarnieri. Ver, não ver e aprender: a participação de crianças com baixa visão e cegueira na escola. Campinas: Cadernos Cedes - Unicamp, 2008. Disponível em: <www.scielo.br/pdf/ccedes/v28n75/v28n75a05.pdf> acesso em 19 de abril de 2019.

[14] Maceió, Conselho Municipal de Educação de Alagoas 2016. Disponível em < http://comedmaceiocomed.blogspot.com/p/blog-page_12.html> acesso em 19 de abril de 2019.

[15] Pereira Neto, L. L., Brasileiro, R. M. O., Nonato, B. J. A. D., Vieira, J. E. L., Souza Junior, G. H. A Matemática Na Educação Básica: (re)discutindo metodologias para o ensino fundamental. Anais do 8o Congresso Brasileiro de Extensão Universitária-Cbeu, Natal-RN, 2018.

[16] Plaisance, Eric. Da educação especial à educação inclusiva: esclarecendo as palavras para definir as práticas. Revista Educação. Porto Alegre. v. 38, n. 2, p.230-238. 2015.

[17] Silva, R. A. O uso de material didático de manipulação no cotidiano da sala de aula de matemática. 2012. $125 f$. Dissertação (Mestrado) - Universidade Estadual da Paraíba -UEPB, Campina Grande, 2012.

[18] Uliana, M. R.; Inclusão de estudantes cegos nas aulas de matemática: a construção de um kit pedagógico. Bolema, vol.27 no.46 Rio Claro Aug. $2013 . \quad$ Disponível em: http://www.scielo.br/scielo.php?script=sci_arttext\&pid=S0103-636X2013000300017\#end > acesso em 04 de nov. de 2018. 


\section{Capítulo 11}

Ensino e aprendizagem sobre Teoria dos Números: Debates e discussões

\section{Edmilson Pereira \\ José Messildo Viana Nunes}

Resumo: 0 presente trabalho tem como objetivo refletir sobre como a Teoria dos Números é discutida em algumas pesquisas científicas na área da Educação Matemática. Para tal desenvolvemos uma meta-análise de sobre o tema Teoria dos Números no portal de periódicos da Coordenação de Aperfeiçoamento de Pessoal de Nível Superior. Para auxílio das discussões nos apoiaremos nos trabalhos da pesquisadora Rina Zazkis. A meta-analise nos possibilitou ter um panorama de pesquisas sobre o tema Teoria dos Números em pesquisas no Brasil.

palavras-chave: Meta-análise. Teoria dos números. Números. 


\section{INTRODUÇÃO}

Os números inteiros compõem um dos principais temas da Teoria dos Números (TN), os números são uma parte ativa da vida do cidadão desde a mais tenra idade, pois não estão somente presentes na escola, mas permeiam inúmeras práticas sociais, como contagem das mais simples às mais complexas: troca, compra, venda, aplicação, etc. De modo geral para as crianças é um instrumento básico que permite que façam pequenas contagens. As situações favoráveis à aprendizagem do conhecimento matemático são situações do cotidiano das crianças, sendo estas mais significativas do que situações sem contexto que lhe dê significado.

O conceito de número, ou a aquisição do conceito de número passa pelas relações de classificação e serialização, ou seja, em conhecer as semelhanças e diferenças em relação a coleções de objetos. Esta aquisição é gradual e pode ser alcançada à medida que a criança vai internalizando experiências diferentes e relacionadas, como:

1ํ. Percepção de quantidades gerais: muitos, poucos, alguns, suficiente, etc.;

2‥ Distinção e comparação de quantidades de objetos: existem tantos quantos; não há tantos como; aqui há mais do que aqui; aqui há menos do que aqui;

3‥ 0 princípio da unicidade: o filho nomeia os objetos com o nome "um". Então Se você quiser expressar uma quantidade maior que um, dois, por exemplo, a criança dirá "Um e um";

4a Generalização: A criança tem que intelectualizar o conceito "um" como generalização da singularidade. Desta forma, ao visualizar um livro, ele será expresso dizendo "um", como se você vir um balão, um sorvete, ele diria "um" também.

Nesse sentido, o pensamento lógico-matemático é aquele que emerge das relações entre objetos e vem da própria elaboração da criança a partir do contato com o mundo que a rodeia. Surge através da coordenação dos relacionamentos que se criou anteriormente entre os objetos. Neste processo de interação o sujeito pode extrair informações de dois elementos: a ação e o objeto (PIAGET, 1978).

0 estudo da aritmética tem um lugar privilegiado na matemática dos níveis básicos se apresenta como fundamental para a educação, para a vida cotidiana, treinamento e desempenho profissional, e o cultivo do pensamento cientifico e critico. A aritmética é uma área da matemática que tem sido foco de muitos estudos em Educação Matemática como: operações com dígitos simples, operações com números de dois e mais dígitos, a estimativa, o sentido numérico, a resolução de problemas, etc.

A apropriação de noções de números envolve aquisição de habilidades para o uso de conhecimento numérico, formulação de proposições matemáticas, desenvolvimento de estratégias úteis para manipular números, realização de operações, ou seja, está relacionada a resolução problemas de toda ordem.

Além disso, a noção de número inclui habilidades para identificar, saber e lidar com a ordem dos números, as várias representações do mesmo número. As operações com números inclui a compreensão do efeito das operações nos resultados, a conhecimento das propriedades das operações (comutatividade, associatividade e distribuição), sua aplicação na criação de procedimentos de estimação e cálculo mental e compreensão das relações entre operações. As aplicações de números e suas operações na solução de problemas é a própria aplicação do conhecimento sobre números e suas operações em situações que requerem gerenciamento quantitativo, que envolve habilidades como determinar a operação necessária em relação ao contexto de um problema. Embora o sentido numérico implique habilidades complexas, seu desenvolvimento começa antes de entrar na escola e continua por toda a escola básica.

No estudo de Teoria dos Números elementar de grande riqueza e complexidade são os estudos de frações e proporções. Essa complexidade se justifica no fato de que as frações podem ser vistas com vários significados. As frações descrevem uma relação de parte-todo quando uma unidade ou todo é dividido em partes iguais e a fração indica uma ou mais dessas partes. A divisão como um número ocorre ao conceber uma divisão como uma fração e vice-versa; isso implica reconhecer as divisões com um dividendo maior que o divisor como frações (impróprias) e frações próprias à maneira de divisões com um dividendo menor que o divisor.

Em Teoria dos Números a álgebra é o ramo da matemática que lida com a simbolização das relações numéricas, estruturas matemáticas e como operar com estes, ou seja, os conceitos, princípios e métodos da álgebra são ferramentas intelectuais poderosas para representar informações quantitativas e razão sobre essa informação. 0 pensamento algébrico no ensino fundamental começa com o desenvolvimento do sentido numérico. 
0 pensamento algébrico envolvem representação, raciocínio proporcional, o significado de variáveis, padrões e funções, raciocínio indutivo e raciocínio dedutivo. Que inclui a construção e representação de padrões e regularidades, generalizações deliberadas e, mais exploração ativa e importante na solução de problemas e formulação de conjecturas.

De acordo com Sautoy (2013), a escrita dos números primos no decorrer da história, é muito variada de acordo com cultura que faz seu registro, ao passar dos tempos. 0 autor destaca que sociedade egípcia se modernizava, aumentando a necessidade de instrumentos para registrar os impostos, medir terras e aumentar a construção de pirâmides.

Segundo o autor supracitado, na linguagem o registro era feito por hieróglifos para escrever números já possuindo um sistema numérico baseado em potências de base 10, como o sistema decimal que usamos em nossos dias. Então o número primo 200.201 poderia ser escrito de forma econômica, já que quantidades de símbolos são bem menores, diferente do número primo 9.999 .991 em hieróglifos teríamos que ter 55 símbolos para escrevê-lo. Os números primos passando pelas diversas culturas, no espaço e tempo cronológico da história humana, que aparecem na forma de letras para os povos hebraicos, uma vez que não eram significativos em sua cultura, mas sim números correlacionados eram como, por exemplo, os números perfeitos. Já os chineses provavelmente foram uma das primeiras culturas a dar importância aos números primos. Acreditando que cada número tinha seu próprio gênero (números pares eram femininos e números impares masculinos). De qualquer forma observamos na cultura de muitos povos a forma de representar a escrita de números, como os números primos são infinitos a sua forma de escrever todos eles. Já Euclides foi o primeiro a tentar escrever todos eles, mas provou que nenhuma lista finita poderia conter todos os números primos, há um numero infinito de primos.

Mas ele não conseguiu dizer onde esses números estão. Podemos gerar números primos seguindo alguns padrões, como o crivo de Erastóstenes, os primeiros gêmeos usados por Euclides, que foi usado para demonstrar uma infinidade de números primos gêmeos, passando por Oliver Sacks com sua obra "0 homem que confundiu sua mulher com um chapéu", conta a história de dois gêmeos autistas que usavam os números primos como uma forma de linguagem. Mas foi com Fermat que se deu o teste de detecção de primos, como 2p. Tendo como contribuição do húngaro Paul Erdos que conseguiu estimar, mas não conseguindo provar de maneira rigorosa que números menores que $101^{50}$ são primos (Sautoy, 2013).

Levando em conta os coneitos da pscicologia e mais especificamente da psicologia na Educação Matemática, o estudo da matemática tem sido feitas a partir de diferentes perspectivas, de concepção da aprendizagem em que são apoiados. Havendo um confronto entre aqueles que apoiam que se aprende habilidades matemáticas elementares com base na instrução e práticas de exercício e aqueles que defendem que é necessário apreender ideias e raciocínio concomitante a resolução de problemas, com foco no significado e na compreensão dos conceitos.

Importantes foram as contribuições de Jean Piaget, com estudos das operações lógicas e variadas atividades matemáticas básicas que ele considerou pré-requisitos para a compreensão de número e medição. Mesmo ele não estando preocupado com os problemas de aprendizagem da matemática, muitas das suas contribuições ainda são levadas em consideração no ensino da matemática elementar e foram incorporadas a educação.

\section{REFLEXÕES SOBRE 0 TEMA}

O quadro teórico adotado como concepção que norteará nossa pesquisa se fundamenta nas obras da pesquisadora canadense Rina Zazkis, cuja pesquisa em Educação Matemática, tem foco nos conhecimentos de conteúdos matemáticos de futuros professores, como aprendem e ensinam e como esses conhecimentos são adquiridos, construídos e modificados. 0 foco da autora é como ensinar, aprender e compreender a teoria elementar da Teoria dos números.

O trabalho de Wall (2014), sob TN, coadunam os apontamentos de Zazkis (2002, 2006, 2011), ao pesquisar professores do ensino fundamental, o autor destaca a necessidade em preencher as lacunas que existe no currículo tradicional de matemática, voltado para aqueles que ensinam conteúdos relacionados a teoria elementar da Teoria dos números, ele afirma que existe: 
[...] um hiato entre as disciplinas de matemática com foco na compreensão e prática dos estudantes de licenciatura a respeito da matemática presente no currículo fundamental, bem como no aprofundamento de sua compreensão e prática a respeito das formas de ensino da matemática na escola básica. (Wall, 2014, p.7).

De acordo com Wall (2014) o "hiato" pode ser superado integrando conhecimento do conteúdo e conhecimento sobre Educação Matemática, mesclando as experiências curriculares ao conhecimento de didáticos da matemática e dos aspectos da aprendizagem de matemática, aos respectivos suportes teóricos da psicologia da educação que podem se relacionar ao desenvolvimento de quem está aprendendo e se desenvolvendo em sala de aula. Sua obra alerta professores e estudantes de licenciatura, que a capacidade das crianças, a quem se ensina, que na maioria das vezes aprendem e devem assimilar, em apenas em alguns anos a matemática que homens e mulheres da ciência, levaram séculos para entender deva ter uma versão lúdica.

[...] a matemática que abordei foi melhor enquadrada por uma teoria dos números que anteceda Pitágoras - Uma teoria dos números em que a própria teoria dos números e a matemática do comércio seja ludicamente integrada ao que tem sido chamado de matemática recreativa. (Wall, 2014, p.14).

Segundo Brolezzi e Trevizan (2014) a matemática desenvolvida em sala de aula, não tem muito contribuído para alcançar as metas que estão estabelecidas pela disciplina, em vez de raciocínio, valorizase a memorização em vez de adquirir fundamentos para sua vida social, uma vez que muitos professores ficam condicionados a reproduzir atividades dos conteúdos naquele momento.

Autores como João Carlos Vieira e Paulo Antonio Silvani Caetano, na obra "Introdução à Teoria dos números", os processos abstratos e objetos matemáticos vão ao encontro com as pesquisas de Rina Zazkis, sua contribuição da TN, tem sua origem nas práticas cotidianas dos autores, no ensino fundamental de aritmética, que visa em fornecer auxilio e apoio àqueles que ensinam a matemática para o ensino fundamental, os temas são atuais, com a finalidade de aproximar o corpo teórico da TN ao cotidiano da sala de aula, que se diferencia no direcionamento ao universo do aluno, em suas dificuldades e aspirações, o que motiva quem ensina e aprende no campo da matemática.

\section{METODOLOGIA E ANÁLISES}

A presente pesquisa tem como suporte metodológico uma meta-análise, que segundo Lovatto et al. (2007) busca dar um panorama de produções cientificas com interesses de uma compreensão cada vez mais detalhada dos mecanismos científicos, uma vez que é grande o volume de materiais na área de produção científica acadêmica. Diante disso, para analisar e sistematizar as informações há como proposta a metaanálise, procedimento que pode combinar uma gama de resultados de uma grande área de conhecimento em uma síntese em que os dados encontrados podem ser qualificados. Essa síntese nos dá uma visão estatística dos fatos em análise, sendo mais preciso seus efeitos, os resultados apresentados em uma metaanálise permitem vislumbrar casos concordantes ou discordantes e obter uma visão geral da situação em foco.

Durante a fase de pesquisa de artigos e bibliografias consultadas, a meta-análise fornece os meios para fazer uma síntese do conhecimento adquirido sobre o tema a ser pesquisado.

Conforme Lovatto et al. (2007) alguns procedimentos devem ser estabelecidos para se obter sucesso na elaboração da pesquisa, que irá se constituir as boas práticas e compõem a estrutura básica da metaanálise, devendo ser aplicados do modo que se estabeleça uma boa sequência, como: a definição do objetivo, sistematização das informações, codificação de dados, filtragem dos dados e a análise dos dados.

Este estudo descritivo se baseou em uma meta-análise de artigos pesquisados sobre o tema "Teoria dos Números" como questão principal no portal de periódicos da Coordenação de Aperfeiçoamento de Pessoal de Nível Superior (CAPES). Foram escolhidos artigos de três áreas de avaliação listadas nessa base de dados, sendo elas: "Teoria dos números", "Teoria dos números na formação de professor" e "Teoria dos números aplicada à educação". 
A partir de uma listagem inicial dos periódicos das três áreas relacionados ao tema, foram selecionados os artigos dos últimos 5 anos (somente os periódicos disponíveis no Portal de periódicos CAPES), todos os artigos encontrados foram caracterizados e em seguida analisados quanto aos conceitos e abordagens sobre "Teoria dos números". Sendo assim, os resultados encontrados foram sintetizados, e, possibilitaram a elaboração de um panorama geral sobre investigações referentes a Teoria dos números (Quadro 1).

Quadro 1 - Sistematização dos procedimentos metodológicos adotados para a pesquisa

\begin{tabular}{|c|c|}
\hline \multicolumn{2}{|c|}{\begin{tabular}{l|r} 
Pesquisa na base Qualis capes & Listage
\end{tabular}} \\
\hline \multicolumn{2}{|c|}{ 2. Escolha dos artigos } \\
\hline Busca na base Portal de periódicos & $\begin{array}{l}\text { Busca nas paginas dos periódicos de artigos com o } \\
\text { termo Teoria dos números }\end{array}$ \\
\hline \multicolumn{2}{|c|}{ 3. Caracterização dos artigos } \\
\hline \multicolumn{2}{|c|}{$\begin{array}{c}\text { Análise dos artigos selecionados de acordo com os seguintes parâmetros: ano de publicação e objetivo do } \\
\text { artigo }\end{array}$} \\
\hline \multicolumn{2}{|c|}{ 4. Análise do uso Teoria dos números } \\
\hline \multicolumn{2}{|c|}{$\begin{array}{c}\text { Análise dos artigos selecionados de acordo com os seguintes parâmetros: ano de publicação, vinculo com a } \\
\text { educação e ensino aprendizagem. }\end{array}$} \\
\hline \multicolumn{2}{|c|}{ 5. Sistematização da informação } \\
\hline \multicolumn{2}{|c|}{ Elaboração da tabela com panorama geral } \\
\hline
\end{tabular}

Fonte: Elaborado pelos autores.

Apesar da sistematização das informações disponíveis, no presente estudo precisamos delimitar os objetos de análises, já que encontramos um grande número de artigos relacionados com a palavra chave "Teoria dos números", cerca de 5096 artigos, com o refinamento de data de publicação para os anos de 2013 a 2018, assim o número reduziu para 2347. Restringindo a pesquisa ao campo da matemática temos 153 artigos, e, refinando a pesquisa para área de Educação temos 102 artigos, com o refinando para área de Educação Matemática obtivemos 24 artigos referentes a Teoria dos Números.

Com a palavra chave "Teoria dos números na educação", cera de 1372 artigos e com a palavra chave "Teoria dos números na formação de professor", temos 582 artigos.

Os procedimentos metodológicos adotados aqui não buscam esgotar o tema, e sim ter um panorama sobre as pesquisas relativas a "Teria dos números" (Quadro 2).

Quadro 2 - Pesquisa do termo "Teoria dos Números"

\begin{tabular}{|l|c|}
\multicolumn{1}{|c|}{$\quad$ Digitando a palavra chave } & Números de artigos \\
\hline "Teoria dos números" & 5096 \\
\hline Refinando para artigos e ano de publicação, ou seja, 2013 a 2018 & 2347 \\
\hline Refinando para idioma português & 1124 \\
\hline Refinando para a área de tópico mathematics & 136 \\
\hline $\begin{array}{l}\text { Refinando para área de tópico education e educational } \\
\text { Refinando para área de educação matemática/Título do periódico Bolema - Boletim } \\
\text { de Educação Matemática }\end{array}$ & 24 \\
\hline $\begin{array}{l}\text { Refinando para área de educação matemática/Título do periódico Bolema - } \\
\text { Mathematics Education Bulletin }\end{array}$ & 87 \\
\hline $\begin{array}{l}\text { Refinando para área de educação matemática/ Título do periódico Bolema: Boletim } \\
\text { de Educação Matemática }\end{array}$ & 91 \\
\hline $\begin{array}{l}\text { Refinando para área de educação matemática/ Título do periódico } \\
\text { Bolema }\end{array}$ & 90 \\
\hline
\end{tabular}

Fonte: Elaborado pelos autores

Publicações referentes ao termo "Teoria dos números", com refinamento para área de tópico education e educational obtemos 102 artigos, graficamente temos (Gráfico 1): 
Gráfico 1 - Publicações de 2013 a 2108 com a busca Teoria dos Números

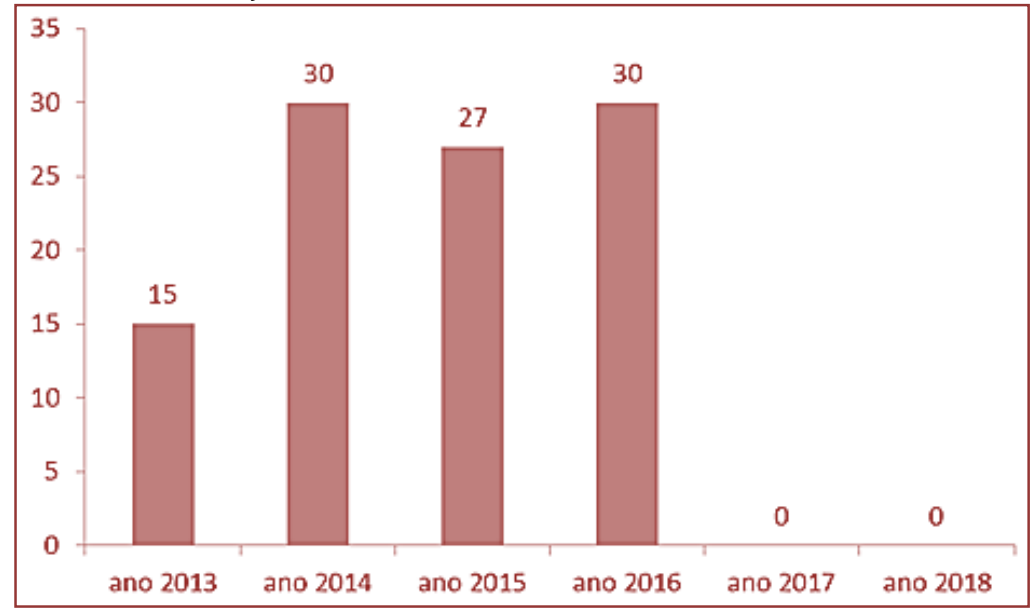

Fonte: Elaborado pelos autores

Pesquisa 02: Palavra chave "Teoria dos números na educação"

Quadro 3 - Pesquisa do termo "Teoria dos números na educação"

\begin{tabular}{|l|c|}
\hline \multicolumn{1}{|c|}{ Digitando a palavra chave } & Números de artigos \\
\hline " Teoria dos números na educação " & 1372 \\
\hline Refinando para artigos e ano de publicação, ou seja, 2013 a 2018 & 801 \\
\hline Refinando para idioma português & 569 \\
\hline Refinando para a área de tópico mathematic & 101 \\
\hline Refinando para área de tópico education e educational & 72 \\
\hline $\begin{array}{l}\text { Refinando para área de educação matemática/Título do periódico Bolema - Boletim } \\
\text { de Educação Matemática }\end{array}$ & 65 \\
\hline $\begin{array}{l}\text { Refinando para área de educação matemática/Título do periódico Bolema - } \\
\text { Mathematics Education Bulletin }\end{array}$ & 03 \\
\hline $\begin{array}{l}\text { Refinando para área de educação matemática/ Título do periódico Bolema Boletim } \\
\text { de Educação Matemática }\end{array}$ & 67 \\
\hline Refinando para área de educação matemática/ Título do periódico Bolema: & \multirow{2}{*}{03} \\
\hline
\end{tabular}

Com a busca do termo "Teoria dos números", com refinamento para área de tópico education e educational obtivemos 72 artigos (Gráfico 2):

Gráfico 2 - Publicações de 2013 a 2108 com a busca Teoria dos números na Educação

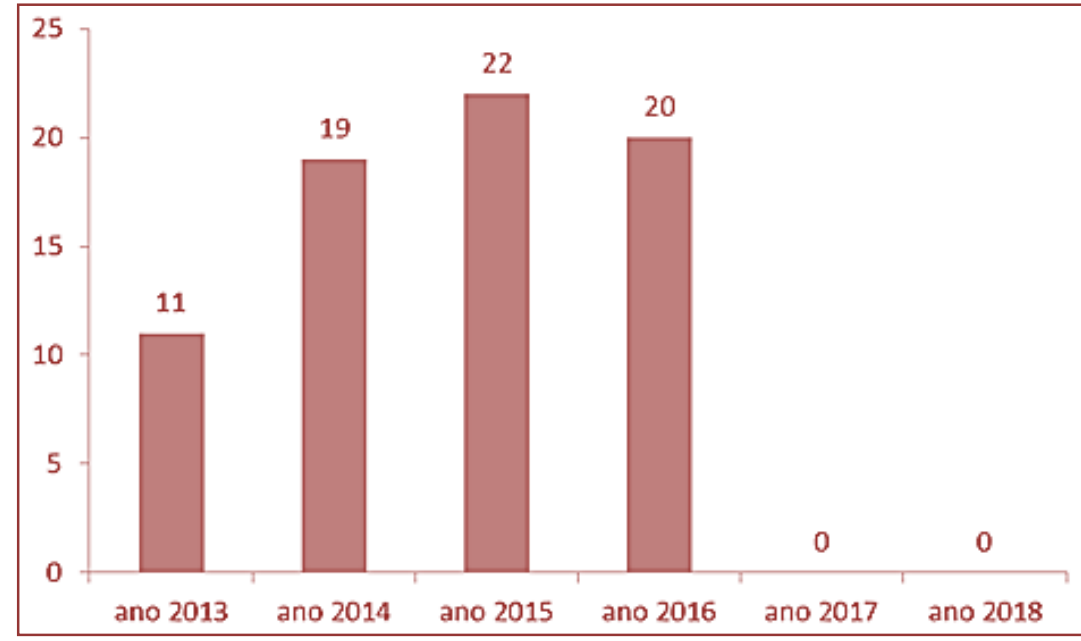

Fonte: Elaborado pelos autores 
Pesquisa do termo "Teoria dos números na formação de professor" (Quadro 4).

Quadro 4 - Pesquisa 01: Palavra chave "Teoria dos números na formação de professor "

\begin{tabular}{|l|c|}
\hline \multicolumn{1}{|c|}{ Digitando a palavra chave } & Números de artigos \\
\hline " Teoria dos números na formação de professor " & 582 \\
\hline Refinando para artigos e ano de publicação, ou seja, 2013 a 2018. & 242 \\
\hline Refinando para idioma português & 69 \\
\hline Refinando para a área de tópico mathematic & 49 \\
\hline Refinando para área de tópico education e educational & 10 \\
\hline $\begin{array}{l}\text { Refinando para área de educação matemática/Título do periódico Bolema - Boletim de } \\
\text { Educação Matemática }\end{array}$ & 45 \\
\hline $\begin{array}{l}\text { Refinando para área de educação matemática/Título do periódico Bolema - Mathematics } \\
\text { Education Bulletin }\end{array}$ & 47 \\
\hline $\begin{array}{l}\text { Refinando para área de educação matemática/Título do periódico Bolema: Boletimde } \\
\text { Educação Matemática }\end{array}$ & 46 \\
\hline Refinando para área de educação matemática/Título do periódico Bolema: & 47 \\
\hline
\end{tabular}
Fonte: Elaborado pelos autores

Constatamos crescimento de pesquisas referentes ao termo "Teoria dos números" para refinamento para área de tópico education e educational com 49 artigos (Gráfico 3).

Gráfico 3 - Publicações de 2013 a 2108 com a busca Teoria dos números na formação de professor

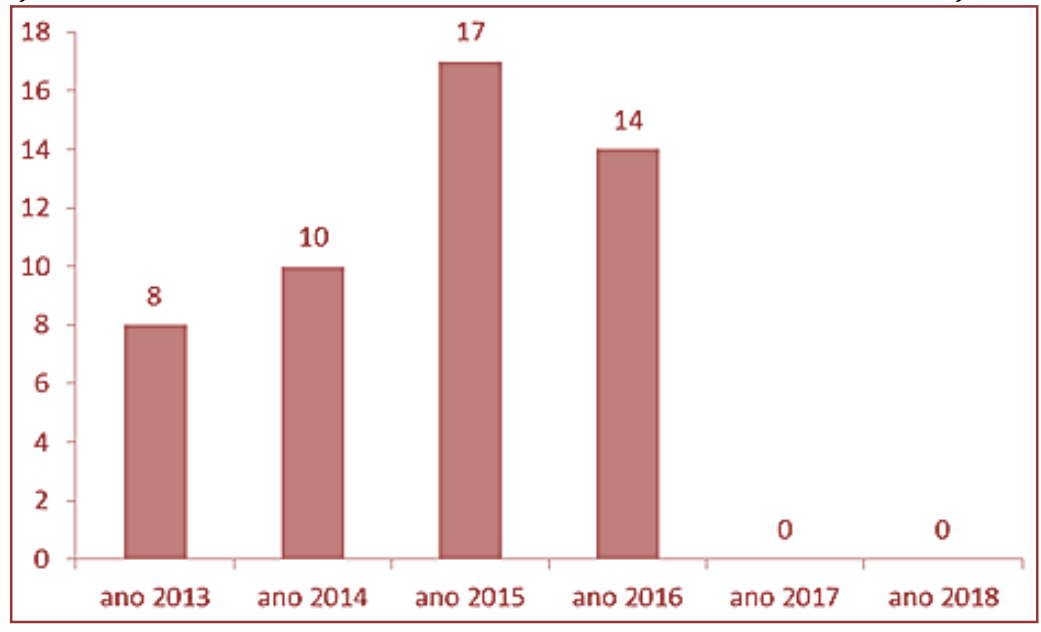

Fonte: Elaborado pelos autores

\section{DISCUSSÕES E REFLEXõES}

Esta seção tem por objetivo identificar a concentração em relação aos artigos analisados no que se refere à Teoria dos Números, com foco na educação. Ao todo, os dados obtidos estão na Tabela 1 e suas representações gráficas (Gráficos 4 e 5).

Tabela 1 - Distribuição do número de artigos ao longo dos anos 2013 a 2018 Palavra chave ano 2013 ano 2014 ano 2015 ano 2016 ano $2017 \mid$ ano 2018 Total

\begin{tabular}{|l|c|c|c|c|c|c|c|}
\hline Teoria dos números & 15 & 30 & 27 & 30 & 0 & 0 & 102 \\
\hline $\begin{array}{l}\text { Teoria dos números na educação } \\
\text { Teoria dos números na formação }\end{array}$ & 11 & 19 & 22 & 20 & 0 & 0 & 72 \\
\hline \multicolumn{1}{|c|}{ Total } & 8 & 10 & 17 & 14 & 0 & 0 & 49 \\
\hline
\end{tabular}


Gráfico 4 - Número de artigos de 2013 a 2018 referente ao panorama geral

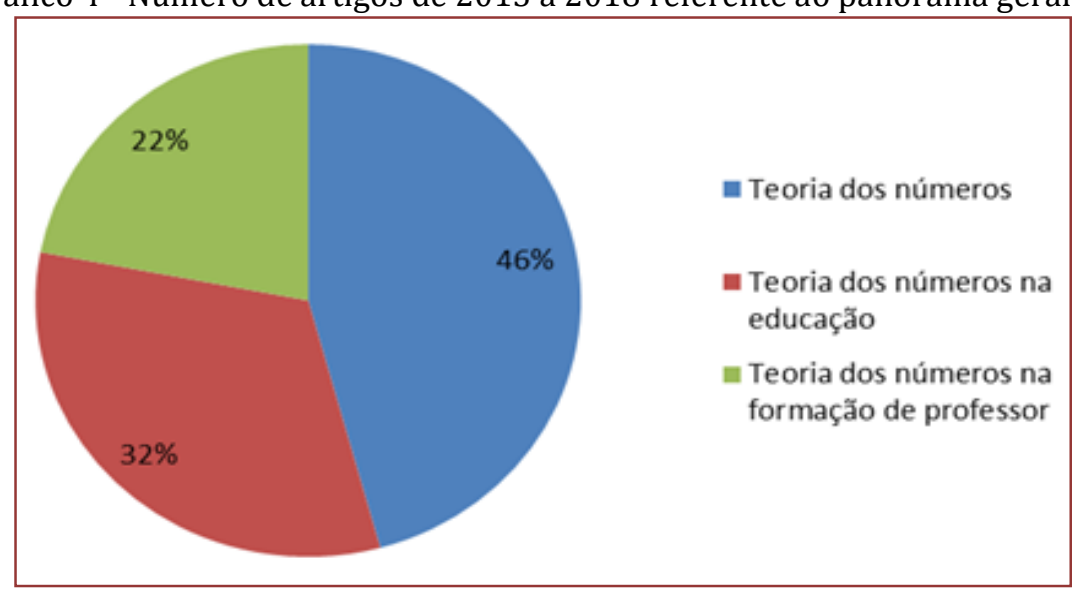

Fonte: Elaborado pelos autores

Gráfico 5 - Número de artigos de 2013 a 2018 referente ao panorama geral

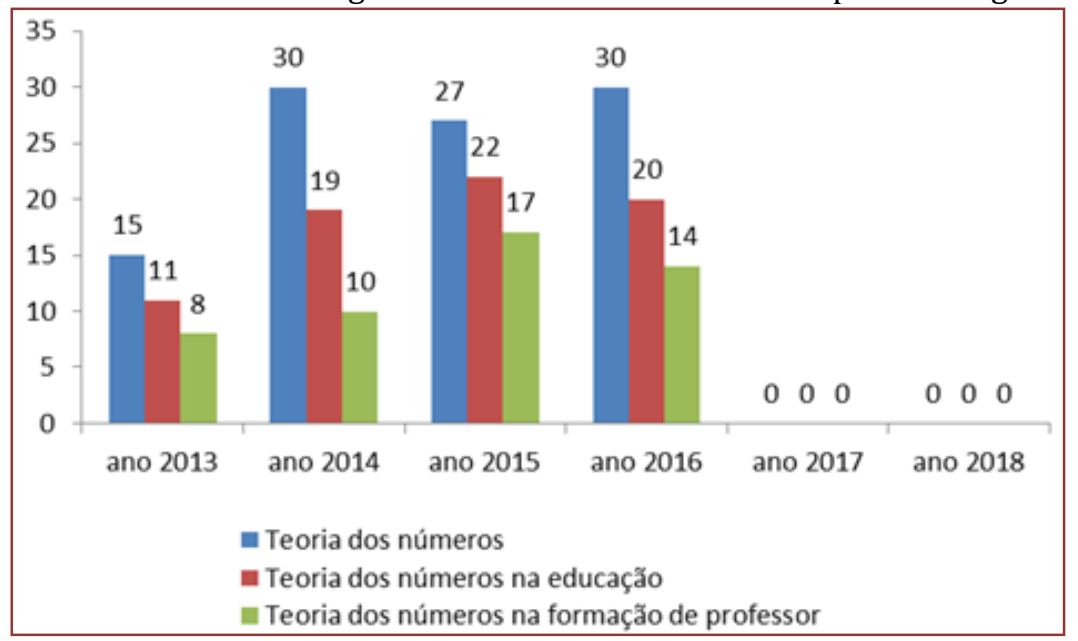

Fonte: Elaborado pelos autores

Pode-se inferir sobre a pesquisa realizada que há certo destaque de investigações sobre "Teoria dos números", o estudo de Teoria dos Números foi alavancado durante o século XX, pois ganhou importância no desenvolvimento de tecnologias modernas de ouras área de ciências. Até meados do século 20, a TN era considerada um ramo da matemática, sem aplicações diretas ao mundo real. Com o advento do mundo informacional, computadorizado e comunicações digitais mostra de modo geral que a teoria dos números poderia fornecer respostas inesperadas para problemas do mundo real.

As melhorias na tecnologia da computação permitiram que os teóricos dos números fizessem avanços notáveis em fatoração de grandes números, determinar primos testar conjeturas e resolver problemas numéricos que dependiam de muitos anos para se chegar a uma conclusão.

A TN Moderna é uma área muito ampla que se desdobra em: teoria elementar dos números, teoria dos números algébricos, teoria dos números analíticos, teoria dos números geométricos e teoria dos números probabilísticos.

O grande acúmulo de artigos acadêmicos, mostrado nos Gráficos 4 e 5 revela sua importância não somente para a própria ciência matemática, mas como para outras áreas, como também: a economia, as áreas de computação digital no desenvolvimento da criptografia, a física na área da computação quântica e ao desenvolvimento de linguagem de softwares.

Pode-se inferir sobre a palavra chave "Teoria dos números na educação", que o grande distanciamento da palavra chave "Teoria dos números", pode ser devido ao campo de educação não fazer uso dessa, ou até mesmo não reconhecer sua validade na prática pedagógica em relação educação matemática os atores envolvidos diretamente e indiretamente, mas é fundamental para o desenvolvimento intelectual de quem aprende. 
Pode contribuir com atitudes e valores, por sua vez, a Teoria dos números na educação contribui para a formação de valores, determinando atitudes e comportamentos. Podem servir como padrões vidas, um estilo de encarar a realidade lógica e coerente, a busca de precisão nos resultados, uma compreensão e expressão claras através do uso de símbolos, a capacidade de abstração, raciocínio e generalização e a percepção da criatividade como valor.

A análise sobre a palavra chave "Teoria dos números na formação de professor", no que confere ao acúmulo de artigos relacionados à formação do professor é discreta se comparada às duas curvas anteriores, já que alguns artigos podem fazer parte da curva de Teoria dos números na educação. Mas é relevante destacar a importância da teoria aliada a práticas de ensino, que ambas não se pode dispensar para aquisição dos conhecimentos em termos de TN na medida em que auxilia o professor a um melhor desenvolvimento de suas aulas e nas metodologias utilizadas.

Durante os anos de 2013 a 2015, o índice de crescimento em publicações acadêmicas teve um salto significativo, devido ao fortalecimento de políticas públicas em relação aos investimento em produção científica durante esses anos, mas que atualmente há um decréscimo constatado nas curvas que decaem de 2016 a 2018 sem nenhuma publicação de material acadêmico nessa faixa no que diz respeito a Teoria dos números. Em termos de ensino aprendizagem Lourdes de la Rosa Onuhic e Luciene Souto Botta, diz:

Apesar de tudo, o que se encontra, em geral, é frustração da parte do professor (por mais que eu me esforce, meus alunos não aprendem...), desinteresse e desânimo da parte dos alunos (para que aprender isso?... onde vou usar essas coisas?... não consigo entender...) e perplexidade da parte da sociedade (gastase tanto dinheiro com escolas, com cursos para professores, com reciclagem, e o ensino cada vez pior...). Testes são aplicados e, a cada novo teste, parece que os resultados são mais desanimadores. 0 que se pode fazer para mudar esse quadro? (Onuchic, Botta, p.5-8,1997).

\section{ANÁLISE DE ALGUNS ARTIGOS}

A partir da Palavra chave "Teoria dos números na formação de professor", como o refinando para área de tópico education e educational, temos 49 artigos. Desse total teceremos reflexões em especial em alguns artigos que contemplaram os aspectos teóricos do presente trabalho, artigos como da autora Luciana M. Elias de Assis sob o título "Re-significando a disciplina de Teoria dos Números na formação do professor de Matemática na Licenciatura". Para o desenvolvimento de sua tese, a autora utilizou uma abordagem de pesquisa qualitativa, que consistiu em analisar as propostas curriculares das disciplinas que tratam de TN em, analisar livros didáticos, buscando compreender a TN como saber a ensinar voltado para a formação inicial do professor da escola básica, procurando levantar possibilidades para re-significar essa área nos currículos da licenciatura em matemática.

Segundo a autora, o interesse pelo tema também partiu de sua trajetória profissional e sua inserção no contexto das diretrizes nacionais para o ensino de matemática nos níveis fundamental e médio, bem como para a formação de professores da escola básica. Destaca-se que dentre suas motivações para o trabalho desenvolvido, estão os questionamentos relacionados ao ensino e aprendizagem de números. Em relação à Teoria dos Números, a autora destaca que embora ela tenha certo potencial formador, essa disciplina vem sendo negligenciada em todos os segmentos de escolaridade.

A autora também relaciona a Teoria dos Números a outros campos da matemática, em especial à Álgebra e à Aritmética, ressaltando que devido aos elementos de vínculo com esses campos da TN aparece com pouca ênfase nos currículos de diferentes níveis de ensino, conforme apontam Campbell e Zazkis (2002). Para esses pesquisadores, conteúdos da Teoria dos Números são incluídos nos cursos de Álgebra ou de Aritmética, em contextos menos formais, o que não garante destaque e importância nas propostas curriculares.

A pesquisa supracitada é corroborada pelo texto A Case for Number Theory in Mathematics Education de Rina Zazkis (2011). De acordo com o texto a teoria dos números é usada para distinguir, por exemplo, a teoria dos números algébricos, onde o conceito de um número é expandido, ou a partir da análise analítica, onde a teoria dos números e que emprega a maquinária do cálculo. Mais hoje sabemos que a "aritmética" está associada principalmente com cálculos elementares ensinados nos anos iniciais, Gauss dizia que para os antigos gregos, a aritmética era o estudo das propriedades dos números inteiros. 
Atualmente este domínio de estudo é conhecido como teoria elementar dos números. "Elementar" não deve ser entendido como algo "simples" ou "fácil". Este rótulo é usado para limitar sua dimensão, que são eles números racionais ou inteiros.

Para Rina Zazkis a TN ainda não assumiu lugar de destaque na Educação Matmática. A alegação é que a atenção às propriedades dos números irá dar razão, as habilidades dos alunos. As pesquisas sobre números inteiros no ensino e aprendizagem da matemática tradicionalmente foca em operações de números e representações decimais, assim conceitos teóricos de números não são destaque em Educação Matemática. As pesquisas, por sua vez, é um reflexo do próprio currículo, uma vez que as investigações de como os alunos aprendem estão relacionadas como eles são ensinados, isto é, conteúdos predominantes no currículo. Mesmo quando é reconheceido a grande variedade entre o que é ensinado em diferentes partes do mundo.

A elegância associada à TN está baseada em argumentos e o mistérios ligados, a alguns problemas relacionados com a TN, as pessoas são atraídas pela beleza e elegância, e as pessoas também são atraídas para o mistério, especialmente se for acessível e ao alcance, como, por exemplo, uma prova bem conhecida da irracionalidade que é a raiz quadrada de 2. Desse exemplo curiosamente, temos contradição, temos número ímpar de fatores em sua decomposição, enquanto o número de fatores primos é par. Esta observação contradiz o Teorema Fundamental da Aritmética, que garante a singularidade da decomposição primária. Este argumento é poderoso em sua elegância, mas assume muito conhecimento mais profundo. 0 poder da percepção muitas vezes depende em conhecimentos prévios ao entendimento que é empregado.

A elegância da TN baseia-se em ideias argumentativas elementares sendo o lugar mais apropriado para desenvolver tais argumentos é o trabalho com padrões, por exemplo, um trem de carro em que o primeiro carro é vermelho, o segundo é azul, o terceiro é vermelho, o quarto é azul, etc. Qual a cor do vigésimo carro?

No artigo de Sandra Magina e Tânia Campos, intitulado "A Fração nas Perspectivas do Professor e do Aluno dos dois Primeiros Ciclos do Ensino Fundamental", as autoras trazem uma análise dos resultados que oferece indícios de que os professores têm, em geral, uma visão do desempenho dos alunos longe do real, havendo uma tendência de superestimar o nível de acertos e aprendizagem, principalmente alunos dos anos iniciais do ensino básico. Uma possível causa para essa visão pode estar relacionada ao fato da maioria dos professores não ter claro os diferentes significados que as frações assumem, o que os leva a apresentar estratégias de ensino que nem sempre auxiliam seus alunos a superar falsas concepções sobre esse conceito, cujos fundamentos estão na Teoria dos números. Os pontos de partida do estudo focaram se os professores têm competência para resolver problemas de fração? Quais estratégias são feitas para ajudar seus alunos a superar eventuais concepções errôneas do conceito?

No texto de Rina Zazkis intitulado From Parity to Divisibility: Reconsidering Definitions (2011) abre uma discussão sobre o significado etimológica das palavras, por exemplo, par e ímpar, muito abordadas na matemática básica, ou seja, uma distinção entre par e ímpar é uma das primeiras propriedades numéricas encontradas pelos alunos em sua exposição a estruturas matemáticas. De acordo com a autora, nenhuma pesquisa ainda examinou a influência da língua nativa dos alunos em sua compreensão. Com base em estudos recentes sobre a influência da linguagem em fazer matemática. Como no estudo de divisibilidade, com números pares e ímpares. Como seu reconheimento pode ser feito por meio do reconhecimento do último digito. É o número 456,798 par ou ímpar? É claro que reconhecemos imediatamente que nao é nem um dos dois. No entanto, para o ensino na escola primária a soma de dois números pares ou dois ímpares, pode representar um desafio para práticas rotineiras da escola primária em termos de formação de professores do ensino fundamental, ou seja, como eles compreedem a formação desses números com mais profundidade.

De acordo com a autora a notação exponencial é um problema generalizado. Além disso, faz referência à memória e a expectativa de que as regras sejam memorizadas, bem como a dependência de um pequeno número de exemplos abordados e específicos são bastante comuns para os futuros professores do ensino fundamental. Também se observa que o cálculo com números ímpares resulta em um número ímpar, o que foi relatado em pesquisas anteriores por ela, isto é, uma crença intuitiva de que realizar uma operação com dois elementos do mesmo tipo resultará em um elemento do mesmo tipo. Tal afirmação foi identificada pela observação das alegações dos estudantes de que produto de dois números primos era primo ou que o produto de dois números irracionais eram irracionais. Embora exista um grande número de exemplos onde esta tendência gera uma conclusão correta, também pode levar a crenças incorretas. 
Um número muito especial, que é o um, pode ser encontrado na lista de primos. A razão para isso é que incluindo 1 com primos é inconsistente com a unicidade da fatoração primária no Teorema Fundamental da Aritmética. A confusão com 1 é esperado, especialmente quando a definição "formal" de que um número primo exatamente 2 fatores não são aplicados, e uma visão "popular" e muitas das vezes afirmada por parte de quem ensina uma vez que não tem conhecimento das implicações matemáticas que sustentam. Afinal, 1 é de fato divisível por 1 e por si só. Enquanto a confusão com 1 é esperada, várias vezes a autora se deparou com os futuros professores do ensino fundamental, uma dificuldade em aceitar que 2 é um número primo. Uma vez que, foi manifestado pela crença de que números primos são ímpares, enquanto 2 é um número par. Esta confusão inicial é facilmente corrigida, sendo que 2 satisfaz tanto a definição "popular" e "formal" para primalidade. No entanto, ainda é percebido como "diferente" entre os primos.

De acordo como resumo da autora, a propriedade de um número como sendo par pode ser abordado como: números pares são múltiplos de 2, eles são divisíveis por 2, eles tem o número 2 como um fator/divisor, e eles não deixam nenhum resto na divisão por 2. Estes são também os números que têm 0 , 2, 4, 6 ou 8 como seus o dígito da unidade quando representado no sistema padrão de valor base de dez lugares. Ou seja, da mesma forma, os números ímpares são aqueles que não têm 2 como fator, que não são divisível por 2, e que deixam um resto de 1 em divisão por 2 . Estes são também os números que têm 1, 3, 5,7 ou 9 como o dígito de sua unidade no padrão representação da base dez (por exemplo: $1358=1 \times 10^{3}$ $+3 \times 10^{2}+5 \times 10^{1}+8 \times 10^{0}$ ).

É essencial que o professor reconheça a equivalência dessas características e possa empregá-las uma vez que a divisibilidade não se traduz facilmente na representação algébrica formal. Embora a autora concorde em atribuir essa dificuldade ao formalismo, também é que esta sequência de construção gradual da noção de paridade ignora um elemento importante - o foco dos alunos, às vezes dando importância ao último dígito. No entanto, os conceitos de par e ímpar pode exigir reaprendizagem, para que se tenha uma nova compreensão. Também no texto de titulo Divisibility: From Action to Object, que trata a divisibilidade da ação ao objeto Zazkis (2011) inicia com uma pergunta, seria os números primos apenas consequência da divisibilidade de números ou um achado de números especiais?

A noção de divisibilidade está relacionada às relações multiplicativas entre números inteiros, ou seja, os números pares são aqueles divisíveis por 2 e os números primos são aqueles divisíveis por um número diferente de 1 e em si mesmo. A divisibilidade foi uma das primeiras questões de interesse da pesquisa de Rina Zazkis, a atenção detalhada à divisibilidade trouxe à luz outras questões. A noção de divisão está vinculada não apenas no significado do conceito de divisibilidade, mas na raiz da própria palavra, em seu texto é descrito vários métodos aplicados por professores em perspectiva em abordar questões relativas à divisibilidade. Como a decomposição de primos, fatores primos e não pares primos, divisibilidades e operações aritméticos, teste de divisibilidade e a linguagem da divisibilidade estuda geralmente em nível de graduação.

Os testes de divisibilidade, por vezes usado como regras de divisibilidade, fazem parte de qualquer Currículo em matemática para ensino fundamental. São apresentados, exemplificados e em muitos casos comprovados na maioria dos livros didáticos voltados para cursos para professores. As regras de divisibilidade sempre foram um dos tópicos importantes na pesquisa de Rina Zazkis, na tentativa de estabelecer a noção de divisibilidade como uma relação entre números antes de qualquer consideração das regras de divisibilidade, sendo que as regras de divisibilidade é um "atalho" ou um procedimento conveniente, eles são discutidos principalmente a partir da perspectiva de apreciação da estrutura matemática e da estética, e não pela sua utilidade.

Algumas provas para as regras são fornecidas, enquanto outras são apresentadas como uma tarefa para exploração e melhoria na compreensão. 0 último dígito do número serve como um critério discriminante na determinação de vários casos de divisibilidade, especificamente, divisibilidade por 2, 5 e 10 . A consideração do último dígito pode ser estendida para dois ou mais últimos. No entanto, focar no último dígito ou nos últimos dígitos do um número é útil em poucos casos. Apesar disso, seja porque o primeiro teste já aprendido ou por causa da facilidade de implementação, há uma tendência de os alunos se concentrarem no último dígito e generalizarem a aplicabilidade destes testes.

Qual o significado matemático da palavra "divisível"? "Divisíveis" e "divide”, suas possíveis interpretações e interpretações errôneas, bem como outras palavras que os alunos usam para expressar divisibilidade. Há pelo menos cinco maneiras diferentes e também equivalentes de dizer que um número é divisível por outro de acordo com Rina Zazkis. Dados dois números naturais a e b, dizemos: 
- $\quad$ a é divisível por b;

- $\quad$ b divide um;

- $\quad$ b é um fator de $a$;

- $\quad$ b é um divisor de a;

- $\quad a$ é um múltiplo de b.

Essas expressões estão de acordo com o vocabulário matemático formal encontrado nos livros acessíveis de matemática.

No entanto, é evidente que essas expressões não são as difundidas na escola básica. A imagem que se tem sobre o conceito de divisibilidade que muitas das vezes está relacionada ao nível de confiança sobre o tema divisibilidade, isto é, quando o nível de confiança é menor, o vocabulário informal prevalece. A noção de divisibilidade em geral é usada em situações cotidianas. Mas pensando em divisão como uma operação entre números racionais, qualquer número pode ser dividido por qualquer número (diferente de zero) e o resultado operação é um número racional. Pensando em divisão como uma operação entre números inteiros, qualquer número também pode ser dividido por qualquer número (diferente de zero), e o resultado dessa operação é um par de números. Ou seja, números inteiros, quociente e resto, onde o resto pode ser zero. Número primo é um número que pode ser dividido por um e si mesmo, não há outros fatores que entram nesse número.

A divisibilidade é um fenômeno comum que pode levar a confusões e equívocos. Outro tema comum durante a sua pesquisa é observado, na descrição dos alunos sobre a divisibilidade que pode ser a imagem mental ou um processo de divisão. Uma definição matemática de divisibilidade pode ser interpretada da seguinte maneira: Um número A é divisível por um número B se objetos A puderem ser organizados em grupos B (linhas, colunas) de forma que haja o mesmo número de objetos em cada grupo. Essa interpretação é consistente com uma visão partitiva da divisão. Tomando uma visão de medição ou cotação na divisão, a imagem que pode acompanhar a divisão está cobrindo o comprimento de unidades $\mathrm{A}$ com segmentos B longos. Ao dizer "entra", "encaixa", "pode ser colocado", os participantes podem visualizar este processo de divisão. Na verdade, "entra" ou "entra uniformemente" parecia ser a expressão mais popular usada para descrever a divisibilidade por professores em perspectiva.

No artigo de Eliane Maria de Oliveira Araman e Irinéa de Lourdes Batista, com título "Contribuições da História da Matemática para a Construção dos Saberes do Professor de Matemática", os autores trazem em sua investigação a relevância dos conhecimentos da história da matemática para o processo de formação dos saberes docentes. Ao estudar conceito de matemática, a partir de uma abordagem histórica, pode-se caminhar para uma compreensão de como aquele conceito foi sendo desenvolvido, e quais elementos conceituais necessários para a sua compreensão, os pontos de maior dificuldade, por que eles foram importantes naquela época, por que são importantes até hoje, quais foram às necessidades para o desenvolvimento de um determinado conceito. Com objetivo compreender e explicitar algumas relações entre os conhecimentos teóricos e metodológicos da história da matemática e a construção dos saberes de professores de matemática.

No artigo de Josélia Euzébio da Rosa, Ademir Damazio e Gisele Mezzari Silveira, sob o título de "O Sistema de Numeração nas Tarefas Propostas por Davýdov e seus Colaboradores para o Ensino de Matemática", os autores trazem uma Investigação a respeito do movimento conceitual adotado por Davýdov e seus colaboradores ao proporem o ensino do Sistema de Numeração. Davýdov, da área da psicologia e seguidor de Vygotski, coordenou o processo de elaboração de uma proposta para o ensino de Matemática, na União Soviética, a partir dos pressupostos da Teoria Histórico-Cultural.

No artigo de Fernanda Andréa F. Silva, Mônica Maria Lins Santiago e Marcelo Câmara dos Santos, com título "Significados e Representações dos Números Racionais Abordados no Exame Nacional do Ensino Médio - ENEM", os autores trazem uma pesquisa, em que se propõem a investigar quais são os significados e as representações dos números racionais que são contemplados no Exame Nacional do Ensino Médio - ENEM. Que também vai de encontro com o artigo de João Pedro da Ponte e Marisa Quaresma, com título "Representações e Processos de Raciocínio na Comparação e Ordenação de Números Racionais numa Abordagem Exploratória", em que os autores procuram saber o que leva os alunos a desenvolver a sua capacidade de comparação e ordenação de números racionais, o que levam a usar diferentes representações e processos de raciocínio informais e formais. 
No artigo de Dario Fiorentini e Ana Teresa de Carvalho Correa de Oliveira de título "O Lugar das Matemáticas na Licenciatura em Matemática: que matemáticas e que práticas formativas?" abrem a discussão acerca do lugar da matemática na formação do futuro professor, que práticas podem contribuir para que o futuro professor possa se apropriar dessa matemática fundamental para seu trabalho profissional? Que tem sido alvo de inúmeras críticas, tanto por parte de pesquisadores como de professores formadores, de egressos e de licenciados.

Essas críticas referem-se aos currículos, ao distanciamento ou desconexão entre as práticas de formação e as práticas de ensinar e aprender na escola básica, à falta de diálogo entre as disciplinas específicas. Segundo Zazkis (2011) com o texto de título Pedagogy of Relearning. Sabemos que muitas são as discussões recentes sobre Educação Matemática que se concentram nos conhecimento dos professores. Dos estudos em Teoria dos Números o objetivo da pesquisa de Rina Zazkis é encontrar maneiras de reconstruir a compreensão dos professores/aprendizes sobre esses conceitos. No que segue, são várias ideias destinadas a auxiliar os professores em sua reaprendizagem da matemática, pode-se encontrar essas ideias aplicáveis para aprender, isto é, fazer "certo" desde o começo, e não apenas reaprender. Criando experiência matemática para futuros professores com os conceitos que não são novos para eles é o reaprendizado que é tema de trabalho e interesse.

Segundo Rina Zazkis foi enfatizado a ideia de decomposição que conseguiu a atenção dos alunos de maneira que conclusões referentes a questões do tipo fatores e múltiplos podem ser considerados como uma estrutura de números apresentada. A exposição a grandes números ajudou os alunos a fazer inferências sobre divisibilidade e indivisibilidade sem realização de divisão. Eles pareciam aplicar os critérios corretamente e pareciam confiantes em seu julgamento. Portanto, ela acredita que a transparente características de primeira decomposição de números tornaram-se transparentes para seus alunos. No mundo é muito útil para entender várias propriedades estruturais do sistema numérico. Além disso, ela sugere que a acessibilidade da teoria dos números baseada padrões possa ajudar no desenvolvimento da apreciação da matemática como um campo de estudo, em vez de uma coleção de regras e fórmulas arbitrárias. Isso também oferece uma oportunidade para explorar exemplos escolhidos pelo usuário, do que aqueles sugeridos por livros didáticos e instrutores.

\section{CONCLUSÃO}

O estudo da meta-análise nos permite quantificar de maneira sistemática as obras estudadas, possibilitou fornecer procedimentos confiáveis e sínteses de estudos produzidos e acumulados de um determinado período, no caso da presente pesquisa no portal de periódicos CAPES/MEC, o objetivo da síntese da pesquisa foi concentrar em um só trabalho os resultados encontrados na presente pesquisa do resultado de vários autores sobre o tema Teoria dos números. 0 quadro teórico adotado atribui um papel essencial aos aspectos da construção epistemológica, ou seja, a investigação da natureza do conhecimento matemático da Teoria dos números, uma vez que no campo da Educação Matemática, a pesquisa identificou vários contextos em que o estudo da Teoria dos números contribui, como: na psicologia da aprendizagem, nas didáticas de educação matemática, na matemática abstrata, na história da matemática entre outras. Mas a pesquisa de meta-análise identificou um número reduzido de artigos focado na área de educação de modo geral, mas que sua importância com o passar desse período em que foi produzido vem aumentando durante os últimos anos.

A importância da Teoria dos Números vem sendo negligenciada em vários campos de aprendizado, seja do básico ao fundamental, mas nos estudos da Educação Matemática Zazkis (2002), defende como um campo de estudo, com o texto Toward Number Theory as a Conceptual Field, o presente texto destaca que nos contextos da Educação Matemática dos dias de hoje, parece que não foi dada muita atenção a contextos formais relacionados com propriedades e estruturas do número em si, ou seja, o significado matemático não é apenas uma questão de conceitos e experiências familiares do dia a dia do mundo real. É também uma questão de desenvolver os fundamentos conceituais para fazer abstração clara e distinções gerais.

Um caso em questão tem a ver com a compreensão das diferenças entre números inteiros e números racionais e os diferentes tipos de procedimentos envolvidos na operação com eles. Ja se sabe que quem ensina matemática para o ensino basico têm muitas dificuldades processuais e semânticas a este respeito. Os professores precisam entender qual é o papel da teoria dos números na prática cotidiana de ensinar matemática? De acordo com o Currículo e os Padrões de Avaliação do Conselho Nacional de Professores de Matemática (NCTM) de 1989: A Teoria dos Números oferece muitas oportunidades para explorações interessantes, agradáveis e úteis. Essas explorações têm compensações na resolução de problemas, na compreensão e desenvolvem outros conceitos matemáticos, ilustrando a beleza da matemática e 
compreendendo os aspectos humanos do desenvolvimento histórico de número. Apesar dessas, a Teoria dos Números não é tipicamente um tópico em si mesmo no currículo do ensino fundamental e médio. Dado o papel central do número no currículo de matemática e o papel central da teoria dos números na história da matemática, é um pouco surpreendente que a Teoria dos Números não desempenha um papel mais central na matemática. Pode-se destacar que o trabalho da autora com relação ao tema é recente, e forneceu importantes contribuições para presente pesquisa.

\section{REFERÊNCIAS}

[1] Araman, Eliane Maria de Oliveira; Batista, Irineia de Lourdes. Contribuições da História da Matemática para a Construção dos Saberes do Professor de Matemática. Bolema, Rio Claro (SP), v. 27, n. 45, p. 1-30, abr. 2013.

[2] Assis, Luciana M. Elias. Re-significando a disciplina de Teoria dos Números na formação do professor de Matemática na Licenciatura. 2007. 281f. (Doutorado em Educação Matemática) - Programa de Pós-Graduação em Educação Matemática, Pontifícia Universidade Católica, São Paulo, 2007. (Orientadora: Sílvia Dias Alcântara Machado).

[3] Brolezzi, Antonio Carlos; Trevizam, Wanessa Aparecida. Como ensinar analise combinatória. Ed. livraria da física. 2016.

[4] D’ Ambrosio, Ubiratan. Educação Matemática da teoria a pratica. Ed. Papirus.1996.

[5] Fiorentini, Dario; Oliveira, Ana Teresa de Carvalho Correa de. O Lugar das Matemáticas na Licenciatura em Matemática: que matemáticas e que práticas formativas?. Bolema, Rio Claro (SP), v. 27, n. 47, p. 917-938, dez. 2013.

[6] Medeiros, João Bosco. Redação Cientifica. Ed. Atlas 10o edição, 2009.

[7] Onuhic, Lourdes de la Rosa; Botta, Luciene Souto. Uma nova visão sobre o ensino e a aprendizagem dos números racionais. Revista de Educação Matemática. São Paulo: SBEM, ano 5, n. 3, p. 5-8, 1997

[8] Lovatto P.A., Lehnen C.R., Andretta I., Carvalho A.D., Hauschild L. Meta análise em pesquisas científicas enfoque em metodologias. Revista Brasileira de Zootecnia. 2007.

[9] Ponte, João Pedro da; Quaresma, Marisa. Representações e Processos de Raciocínio na Comparação e Ordenação de Números Racionais numa Abordagem Exploratória. Bolema, Rio Claro (SP), v. 28, n. 50, p. 1464-1484, dez. 2014.

[10] Rosa, Josélia Euzébio da; Damazio, Ademir; Silveira, Gisele Mezzari. O Sistema de Numeração nas Tarefas Propostas por Davýdov e seus Colaboradores para o Ensino de Matemática. Bolema, Rio Claro (SP), v. 28, n. 50, p. 1135-1154, dez. 2014.

[11] Magina, Sandra; CAMPOS, Tânia. A Fração nas Perspectivas do Professor e do Aluno dos Dois Primeiros Ciclos do Ensino Fundamental. Bolema, Rio Claro (SP), Ano 21, n 31, 2008, p. 23 a 40.24

[12] Sautoy, Marcus du. Os Mistérios dos números: Uma viagem pelos grandes enigmas da matemática. Ed. Zahar. 2013.

[13] SBM, 2017-2018. Matemática 2018-Biênio da matemática Brasil. Ed. sbm. 2018.

[14] Silva, Fernanda Andréa F.; Santiago, Mônica Maria Lins; Santos, Marcelo Câmara dos. Significados e Representações dos Números Racionais Abordados no Exame Nacional do Ensino Médio - ENEM. Bolema, Rio Claro (SP), v. 28, n. 50, p. 1485-1504, dez. 2014.

[15] Wall, Edward S. Teoria dos números para professores do ensino fundamental. Ed. Amgh, 2014.

[16] Zazkis, Rina; Campbell Stephen R. Learning and Teaching Number Theory Research in Cognition and Instruction. 2002.

[17] Zazkis, Rina; Campbell Stephen R. Number Theory in Mathematics Education Perspectives and Prospects. 2006.

[18] Zazkis, Rina. Relearning Mathematics A Challenge for Prospective Elementary School Teachers. 2011. 


\section{Capitulo 12}

\section{Explorando o conceito de medidas dentro de uma receita}

\section{Ligiane Oliveira dos Santos Souza \\ Elizane Gomes do Espirito Santo Tanques \\ Lutecia Martins da Silva \\ Mariluce Aparecida de Lima \\ Aristimar Roberta de Oliveira \\ Fernanda Souza de Arruda}

Resumo: A escolha do tema que envolve a exploração do conceito de medidas em seu processo de ensino-aprendizagem, faz parte do cotidiano vivenciado pela comunidade eja. 0 estudo da Matemática aplicado à atividade culinária justifica-se pelo fato de que a preparação dos alimentos poderá facilitar a compreensão de conteúdos curriculares como: fração, unidades de medidas, entre outros, fazendo com que os alunos reconheçam a necessidade da utilização de outros números, que não os naturais, em situações cotidianas. A experiência foi realizada com alunos da $2^{\underline{a}}$ Segmento do Ensino Fundamental no Centro de Educação para Jovens e Adultos (CEJA) 15 de outubro, com o objetivo de realizar uma receita junto com os alunos, para que eles percebam a importância da matemática no nosso cotidiano, e sendo assim as crianças observaram que é importante aprender elaborando receitas e saboreá-las dentro da escola, junto com os colegas de classe e os professores e demais funcionários.

Palavras-chave: Receita, Aprendizagem, Unidades de medidas. 


\section{INTRODUÇÃO}

Estamos constantemente buscando inovar nossas práticas pedagógicas, através de estratégias de ensino que possibilitem ao aluno compreender e dar sentido aos conteúdos abordados, verificando sua aplicabilidade no dia a dia.

Nossos alunos vivem cercados por números em diversas situações cotidianas, como por exemplo, quando observam as horas, a temperatura, os preços, dentre outras, cabendo a nós professores esclarecer e leválos compreender a importância que tem esses números na organização de nossa vida diária.

É possível verificar a importância e a necessidade de se ensinar os conceitos matemáticos de maneira contextualizada na seguinte afirmação:

Para o ser humano exercer a cidadania é necessário saber calcular, medir, raciocinar, argumentar e resolver situações-problema. Assim sendo aprender Matemática é um direito básico de todas as pessoas e uma necessidade individual e social do ser humano e sendo por isso, fundamental na formação de jovens e adultos. No entanto a forma pela qual a Matemática está sendo abordada com memorizações de regras ou de estratégias para resolver problemas não vem contribuindo para uma boa formação, em especial aos alunos da EJA, pois os conteúdos são poucos significativos para os estudantes. (JESUS, 2007, p. 1).

Como grande parte desses educandos estiveram muitos anos afastados da escola e da rotina de estudos nela desenvolvida, possuem naturalmente dificuldades para assimilar e compreender os conteúdos matemáticos, os significados das palavras, a forma como os problemas são construídos, dentre outros aspectos. Inicialmente, apresentam limitações para distinguir as operações que precisam empregar para a "resolução de problemas, têm uma leitura lenta e fragmentada, não respeitam a acentuação e pontuação o que dificulta a interpretação dos textos" (JESUS, 2007, p. 3).

Ao analisarmos a passagem dos conhecimentos culturalmente adquiridos, percebemos nela uma semelhança com a passagem da linguagem oral para a linguagem escrita, visto que os conhecimentos culturais são transmitidos oralmente e foi intenção sistematizá-los e aprofundá-los em sala de aula. 0 entendimento e o respeito às práticas culturais nos apresentam um grande potencial que julgamos pouco ou mal explorado.

Para D’Ambrosio (1998) os aspectos culturais, estéticos e formativos da evolução do aluno quase não podem ser avaliados. Uma visão respeitosa e digna do próprio ser não pode ser medida diretamente, e os valores estéticos quase não são pesados. 0 mesmo acontece com os valores formativos da cultura de grupos sociais ou classes formalmente estabelecidas. Assim como todo ser humano, os grupos culturais e sociais também têm a sua história, e as situações não podem ser postas de um momento para outro, nem tampouco acontece do dia para a noite, fato este citado por Freire (1998):

Não há transição que não implique um ponto de partida, um processo e um ponto de chegada. Todo amanhã se cria num ontem, através de um hoje, de modo que nosso futuro baseia-se no passado e se corporifica no presente. Temos de saber o que fomos e o que somos, para saber o que seremos. (FREIRE, 1998, p. 33).

Também a busca pelo saber formal é, cada vez mais, necessária, não só pelas exigências do dia a dia, mas pela necessidade de instrumentalização para o mercado de trabalho, cada vez mais complexo. Isso se reflete claramente nas instituições que trabalham com a educação de Jovens e Adultos, nas quais o aluno chega com anseios de adquirir novos conhecimentos, mas, principalmente, em busca de uma instrumentalização para o concorrido mercado de trabalho. Segundo Duarte (1996)

A vida cotidiana da sociedade contemporânea torna-se cada vez mais complexa, exige cada vez mais a utilização de conhecimentos e habilidades que não são adquiridos de forma espontânea e natural. A escolarização torna-se cada vez mais necessária à reprodução da cotidianidade. (DUARTE, 1996, p. 50).

É importante, não só para os alunos adultos, mas também para a instituição escolar, a exploração dos conhecimentos culturalmente adquiridos e que servirão de referência para a aquisição dos conhecimentos formais vivenciados pela escola e exigidos por uma sociedade cada vez mais complexa e competitiva. Entretanto, quando o aluno já tem uma noção do que está sendo tratado, também saberá valorar da melhor forma o que está sendo visto, bem como a sua utilização em suas atividades diárias. 
Um ensino contextualizado que considera os saberes prévios dos alunos deve ser o ponto de partida para o processo de ensino, uma vez que eles possuem um trato direto com a Matemática em seu cotidiano. Portanto, sua experiência, pessoal e coletiva, pode tornar as aulas mais dinâmicas e os conteúdos mais fáceis de serem aprendidos. É necessário jamais esquecer que:

Os educandos jovens e adultos, assim como os outros indivíduos da sociedade, se interrelacionam e se relacionam continuamente através de situações do seu dia-a-dia. Tais situações demandam explicações, discussões e análises críticas para uma ampla e amadurecida compreensão das situações e problemas inerentes à sociedade em que vivemos. Até mesmo determinados assuntos corriqueiros, trazidos pelos alunos no cotidiano das aulas de matemática, permitem momentos particularmente férteis de construção de significados. (THEES; FANTINATO, 2012, p. 268).

No entanto o estudo da Matemática aplicada à atividade culinária pode ser justificado pelo fato de que a preparação dos alimentos poderá facilitar a compreensão dos conteúdos curriculares como: fração, números decimais, unidades de medidas entre outros, além de contribuir para a aplicação prática desses conhecimentos, fazendo com que reconheçam a necessidade da utilização de outros números, que não somente os naturais, em situações cotidianas.

Na educação de Jovens e Adultos o ensino do segundo segmento do fundamental trabalham na sua maior parte do tempo com a manipulação de elementos concretos tais como jogos e brincadeiras para construir seus conhecimentos matemáticos. 0 ato de medir envolve dois componentes, o raciocínio lógico e o raciocínio dedutivo. É preciso apropriar-se da lógica para medir e compreender a unidade de medida, pois quando medimos estamos preocupados com quantidades reais e com as relações de tamanho que permitam fazer comparação entre grandezas. Sabemos pela história, que no passado os homens preocupavam-se apenas com a contagem, pois faziam trocas de mercadorias. Com o passar do tempo, percebeu que a contagem não era suficiente para atender às suas necessidades, pois ao cultivar a terra e ao construir nela, precisava fazer medidas.

E assim inserida de forma gradativa a dimensão abstrata em que os conceitos serão construídos somente no domínio das ideias, associada a matemática onde o aluno aprende através da manipulação de objetos.

A ideia desta unidade didática é mostrar o quanto os números naturais, fracionários e decimais estão presentes no nosso cotidiano, e como lidamos com eles de forma tão automática que não os percebemos.

Para alcançar esse objetivo, serão utilizadas receitas culinárias confeccionadas pelos nossos alunos do Eja por serem a maioria dona de casa, que além de fazer parte do cotidiano dos alunos, possibilitam estabelecer relações entre o concreto e o abstrato.

Segundo D'ambrosio (2005, p. 71) “a busca de novas direções para o desenvolvimento da matemática deve ser incorporada ao fazer matemático". Desta forma, é sempre necessário buscar associar os conteúdos teóricos a uma prática que venha realmente tornar o aprendizado mais significativo.

\section{ELABORAÇ̃̃O E APLICAÇÃO DA SEQUÊNCIA DIDÁTICA}

A sequência didática que utilizamos foi elaborada e desenvolvida em duas etapas: Na primeira etapa foi elaborada uma conversa com os alunos, na busca de trocar informações com os mesmos sobre o assunto a ser abordado e verificar o nível de conhecimento da turma.

Nesta fase, é interessante instigar os alunos a socializar suas ideias. Para isso, propõe-se que sejam levantadas as seguintes questões:

1) 0 que vocês acham que é uma receita?

2) Para que serve uma receita?

3) Porque alguém escreve uma receita?

4) 0 que faz com que um texto seja considerado uma receita?

5) Que características esse tipo de texto possui que o torna diferente de outros tipos de textos?

6) Quais são as partes que compõem uma receita?

7) Qual sua receita preferida? 
A segunda etapa foi a aplicação das informações colhidas no momento anterior, eles irão estudar os diversos gêneros discursivos (cotidiano, literário/artístico, escolar, jornalístico, publicitário, jurídico, produção e consumo, entre outros) e que receita faz parte do gênero discursivo do cotidiano, (tabela para esclarecimento em anexo).

Utilizar o quadro-negro para registrar os conceitos e exemplos que facilitem o entendimento do aluno, bem como fonte, para posterior consulta.

\section{- Receita - conceito}

É um texto instrucional, ou seja, ensina como fazer ou utilizar algo.

Tipos de textos considerados receitas

\section{- Receita Culinária}

Tem por objetivo indicar, como preparar alimentos.

- Partes de uma receita culinária.

1) Título (nome da receita)

2) Componentes ou ingredientes (o que utilizar para a receita)

3) Modo de fazer ou preparar (etapas a serem seguidas)

\section{- Receita Médica}

Tem por objetivo, indicar como utilizar determinados medicamentos prescritos por um profissional da área da saúde.

Ao iniciar as atividades práticas que envolveram o manuseio de materiais e o preparo das receitas, foi possível perceber que a maioria dos educandos que, em sala, não encontraram dificuldades para realizar as atividades propostas, não conseguiam associar os exercícios tradicionais realizados, às atividades práticas solicitadas. No início de cada atividade prática, eram retomados os conceitos de forma que os estudantes fizessem a associação do conteúdo em situações reais.

Foi possível constatar que mesmo aqueles estudantes que haviam acertado $100 \%$ das atividades em sala de aula, na hora da prática não conseguiam utilizar o conhecimento que já pareciam dominar.

Esta atividade possibilitou uma experiência de grande significado na vida de muitos alunos da $2^{\underline{a}}$ Segmento do Ensino Fundamental no Centro de Educação para Jovens e Adultos (CEJA) 15 de outubro, pois além de responder as questões propostas, um grupo decidiu colocar em pratica a receita indicada para o estudo. Foi uma agradável e grande surpresa para a escola, quando um grupo de alunas representando a turma toda, entrou na sala trazendo o bolo de laranja, fruto da atividade. São momentos como este, que nos motiva a desenvolver atividades cada vez melhor para os discentes da escola pública e principalmente para o alunado da EJA, que muitas vezes são dedicados e apresentam rendimentos satisfatórios.

Uma questão muito importante que merece ser lembrada é que nossos alunos não têm a mesma formação social e intelectual. Trabalhamos com alunos que pensam de forma diferente, e seu tempo de aprendizagem e elaboração do pensamento são distintos, o que nos leva à necessidade de uma metodologia diferenciada, procurando atender a todos da melhor maneira possível.

Certamente, não teremos uma metodologia para cada aluno, o que seria utópico, mas devemos procurar atender o maior número possível de necessidades e particularidades da nossa sala de aula. Assim, teremos a capacidade de melhorar a qualidade do processo na formação dos conceitos matemáticos que buscamos. Precisamos considerar também que o aluno, principalmente o adulto, já vem para a escola com importantes informações matemáticas do seu cotidiano e das suas relações sociais.

Assim, precisamos ter como base o conhecimento prévio de nossos alunos, auxiliando-os na reelaboração do conhecimento de senso comum, buscando a partir dele o conhecimento científico necessário para a sua inclusão social e no mundo do trabalho. 


\section{CONSIDERAÇõES FINAIS}

Desenvolver essa atividade foi uma experiência única e uma grande oportunidade de conciliar os saberes que os alunos da Educação de Jovens e Adultos trazem da sua vivência na comunidade com os conteúdos da proposta curricular da EJA. A atividade desenvolvida possibilitou avaliar continuamente o aprendizado dos educandos através de atividades tradicionais e práticas, tornando o processo ensino-aprendizagem dinâmico. Também, através dessa experiência, foi possível perceber a necessidade de um equilíbrio entre atividades tradicionais e práticas, sendo que uma não deve excluir a outra, mas sim, se complementarem.

Esse fato ficou evidenciado, quando vários estudantes que seriam "nota 10" ao realizarem uma sequência de exercícios relacionados aos conteúdos frações e números decimais, em sala de aula, não foram capazes de identificar aplicação prática dos mesmos conteúdos. Outro fator a ser observado na aplicação desse tipo de proposta de trabalho, é a quantidade de alunos em sala de aula; tendo sido possível perceber que um melhor resultado era alcançado nas atividades em que havia uma quantidade menor de estudantes envolvidos. As parcerias estabelecidas com outras disciplinas, colegas professores e com as funcionárias da cozinha, foram fundamentais para o sucesso desse trabalho. 0 processo de trabalhar atividades diferenciadas é trabalhoso, desafiador e estressante, mas o resultado final é compensador quando percebemos nossos educandos estabelecendo as relações entre teoria e prática.

Desta forma, a atuação como profissional da educação de Jovens e Adultos requer muito mais do que o conhecimento de um conteúdo previamente estabelecido, mas a ação pedagógica precisa levar em conta uma formação abrangente que possibilite a análise e abstração em situações do cotidiano, capaz de melhorar sua condição social e estabelecer significativa ascensão ao concorrido mundo do trabalho. As discussões estabelecidas buscavam justamente esta integração do cotidiano do indivíduo com uma possível ascensão social e a possibilidade de uma progressão gradual no mundo do trabalho e as consequências dessas possibilidades na vida financeira e relações de convivências a serem estabelecidas.

\section{REFERÊNCIAS}

[1] D’Ambrosio, U. Etnomatemática: elo entre as tradições e a modernidade. 2. ed. Belo Horizonte: Autêntica, 2005.

[2] Duarte, N. O ensino de matemática na educação de adultos. 6. ed. São Paulo: Cortez Editora, 1996.

[3] Freire, P. Conscientização: teoria e prática da libertação: uma Introdução ao pensamento de Paulo Freire. 3. ed., São Paulo: Moraes, 1998.

[4] Jesus, M. M de. A linguagem matemática na educação de jovens e adultos (EJA). Trabalho de Conclusão de Curso, UCB, 2007. Disponível em: www.ucb.br/sites/100/103/TCC/22007/MariluMariadejesus.pdf . Acesso: $02 / 04 / 2019$

[5] Thees, A; Fantinato, M. C. Professores que lecionam matemática na EJA: concepções e práticas letivas. Revista Reflexão e Ação. Santa Cruz do Sul, v.20, n2, p.267-290, jul./dez. 2012. 


\section{Capítulo 13}

o estudo da periodicidade de uma função trigonométrica a partir de um experimento envolvendo a roda gigante

Sandra Regina D' Antonio Verrengia

Vanessa Cristina Rhea

Jessica Suzana Barragan Alves

Resumo: Neste trabalho descrevemos a aplicação de algumas atividades manipulativas voltadas à introdução de conceitos trigonométricos. Tais atividades foram apresentadas a alunos do Ensino Médio de $1^{\underline{0}}$ e $2^{\circ}$ anos com a finalidade de, partindo da observação e manipulação de materiais concretos, envolver tais discentes em uma prática dinâmica e interativa na qual, a partir da discussão com seus pares e com o professor, pudessem pensar a respeito do tema trabalhado de modo a estabelecer relações matemáticas pertinentes, bem como perceber a presença dos conceitos trigonométricos em situações do cotidiano. A experiência aqui apresentada mostra que a utilização de atividades manipulativas, além de estimular a reflexão e o desenvolvimento do pensamento matemático dos discentes convidando-os a pensar, auxilia o trabalho do professor quanto a formalização dos conceitos trigonométricos abordados.

Palavras-chave: Trigonometria; Ensino Médio; Roda-Gigante; Funções Periódicas. 


\section{INTRODUÇÃO}

O conhecimento matemático desde a suas origens é utilizado pelo homem na solução de problemas provenientes de suas práticas sociais seja na agricultura, no comércio, na construção civil, na navegação, na astronomia, etc. Tais problemas agregaram à Matemática novos saberes e geraram novos questionamentos. Questionamentos esses que possibilitaram a produção de novos conhecimentos, dentre os quais se encontram os relacionados à trigonometria.

A origem da trigonometria é incerta. Entretanto, pode-se dizer que o início do desenvolvimento desse ramo da matemática se deu, principalmente, devido a problemas gerados pela Astronomia, Agrimensura e Navegações, por volta do século IV ou V a.C., com os egípcios, babilônios e gregos.

Enquanto, por um lado, os egípcios se preocuparam com as razões de lados de triângulos para as construções de pirâmides; por outro lado, alguns matemáticos gregos, em destaque Aristarco (por volta de 310 -230 a.C.) e Erastótenes (por volta de 276-194 a.C.), se dedicaram a calcular as distâncias do Sol e da Lua à Terra e o tamanho desses planetas (QUINTANEIRO, 2010, p.5).

Apesar de os interesses e motivações suscitados por matemáticos egípcios e gregos serem distintos ambos estavam interessados em resolver problemas práticos que envolviam conhecimentos relacionados à trigonometria. Conhecimentos estes, que foram sendo aprimorados na medida em que foram surgindo novas hipóteses, conjecturas, soluções e outros problemas envolvendo esse tema. Desse modo, no decorrer de séculos foram os problemas matemáticos, que alicerçaram muitos dos conceitos que atualmente são trabalhados em sala de aula a respeito da trigonometria.

Atualmente, nas propostas curriculares de âmbito nacional, denota-se a importância em se aliar a História da Matemática e os conhecimentos matemáticos oriundos dos problemas sociais ao ensino dessa Ciência. De acordo com a Base Nacional Comum Curricular - BNCC,

[...] a Matemática deve ser vista como um processo em permanente construção, como mostra a História da Matemática. Seu estudo não deve se reduzir à apropriação de um aglomerado de conceitos. 0 estudante deve ser motivado a, em seu percurso escolar, questionar, formular, testar e validar hipóteses, buscar contra exemplos, modelar situações, verificar a adequação da resposta a um problema, desenvolver linguagens e, como consequência, construir formas de pensar que o levem a refletir e agir de maneira crítica sobre as questões com as quais ele se depara em seu cotidiano (BRASIL, 2018, p. 131).

Ideia presente também nos PCN's:

A História da Matemática pode oferecer uma importante contribuição ao processo de ensino e aprendizagem dessa área do conhecimento. Ao revelar a Matemática como uma criação humana, ao mostrar necessidades e preocupações de diferentes culturas, em diferentes momentos históricos (BRASIL, 1999, p. 42).

E nas Orientações Curriculares especificamente para o Ensino Médio,

[...] espera-se que os alunos percebam a matemática como um conhecimento social e historicamente construído; saibam apreciar a importância da Matemática no desenvolvimento científico e tecnológico (BRASIL, 2006, p.69).

Especificamente no tocante ao ensino de Trigonometria os Parâmetros Curriculares Nacionais (PCN's) ressaltam a importância de que tal conteúdo seja ensinado com base em aplicações, ou seja, em problemas cujo enfoque recai sobre os conhecimentos trigonométricos:

Outro tema que exemplifica a relação da aprendizagem de Matemática com o desenvolvimento de habilidades e competências é a trigonometria, desde que seu estudo esteja ligado às aplicações, evitando-se o investimento excessivo no cálculo algébrico das identidades e equações [...] (BRASIL, 1999, p. 257).

Assim, a utilização de atividades estruturadas que enfoquem aspectos da história da matemática e a resolução de problemas, tornam-se relevantes, visto que como ressalta Mendes (2001) a aprendizagem dos conceitos matemáticos deve advir da "experiência direta, com situações naturais provenientes do contexto histórico" (MENDES, 2001, p.59). 
Os conteúdos envolvendo a trigonometria são trabalhados na Educação Básica a partir do final do Ensino Fundamental sendo, posteriormente aprofundados, no Ensino Médio. Nos anos finais do Ensino Fundamental os conceitos trigonométricos estudados enfocam as relações trigonométricas no triângulo retângulo com destaque para a solução de situações problemas, de diferentes contextos envolvendo essas relações (PARANÁ, 2018, p.889).

Já no Ensino Médio, segundo as Orientações Curriculares (Brasil, 2006), o trabalho com os conceitos trigonométricos amplia-se indo das relações métricas no triângulo retângulo ao estudo das razões e funções trigonométricas:

As funções trigonométricas devem ser entendidas como extensões das razões trigonométricas então definidas para ângulos com medida entre $0^{\circ}$ e $180^{\circ}$. Os alunos devem ter a oportunidade de traçar gráficos referentes às funções trigonométricas, aqui se entendendo que, quando se escreve $\mathrm{f}(\mathrm{x})=\operatorname{seno}(\mathrm{x})$, usualmente a variável $\mathrm{x}$ corresponde à medida de arco de círculo tomada em radianos. As funções trigonométricas seno e cosseno também devem ser associadas aos fenômenos que apresentam comportamento periódico (BRASIL, 2006, p. 74).

A que se ressaltar que o aprendizado desses conceitos exige dos estudantes um alto nível de abstração e do professor a utilização de metodologias que proporcionem aos discentes não só a compreensão desses conceitos trigonométricos, como também aquisição de conhecimentos para a solução de problemas referentes ao tema.

Para Costa (1997, p. 33 apud PIAGET, 1977)

[...] uma boa forma de se adquirir ou expandir as estruturas cognitivas de um indivíduo é colocá-lo diante de uma situação-problema tal que seus conhecimentos sejam insuficientes para chegar à solução. Isto provocará conflito, sendo esperado que ele busque novas assimilações para modificar as estruturas cognitivas de forma que, ao final do processo, possa exibir o comportamento que resolva o problema.

Costa (1997) recomenda ainda que alguns recursos podem ser utilizados pelo professor com vistas a potencializar atividades que envolvam a resolução de problemas destacando a utilização de materiais manipulativos e o uso da tecnologia.

Desse modo, considerando as orientações presentes nos documentos oficiais a respeito da trigonometria e o fato de que o ensino deve:

Exercitar a curiosidade intelectual e recorrer à abordagem própria das ciências, incluindo a investigação, a reflexão, a análise crítica, a imaginação e a criatividade, para investigar causas, elaborar e testar hipóteses, formular e resolver problemas e criar soluções (inclusive tecnológicas) com base nos conhecimentos das diferentes áreas (BRASIL, 2018, p. 9).

Aplicamos uma atividade em forma de oficina a 25 alunos de $1^{\mathrm{o}}$ e $2^{\mathrm{o}}$ anos do Ensino Médio do Colégio Estadual Doutor Gastão Vidigal na cidade de Maringá - PR, com vistas a retomar os conteúdos de trigonometria estudados nos anos finais do Ensino Fundamental, bem como a explorar o conceito de periodicidade de uma função trigonométrica. Essa atividade fez parte de um Ciclo de Oficinas organizado pela equipe do Laboratório de Ensino de Matemática da Universidade Estadual de Maringá, sendo realizada no dia 22 de novembro de 2018 com duração de 04 horas.

\section{DESENVOLVIMENTO DA EXPERIÊNCIA}

A atividade desenvolvida foi baseada no experimento $A$ roda gigante desenvolvido pela equipe de Matemática e Multimídia da Unicamp e consistia na introdução do conceito de periodicidade de uma função e na retomada de assuntos relacionados aos conceitos trigonométricos estudados no Ensino Fundamental II.

Para iniciar nossas atividades solicitamos aos discentes que se dividissem em cinco equipes. Em seguida, apresentamos a eles o seguinte questionamento: que tipo de relações matemática podemos descrever ao observar a imagem de uma roda gigante? Nesse instante, os discentes pontuaram relações envolvendo a geometria enfocando apenas elementos relacionados a forma e a área da figura. 
Para levá-los a pensar um pouco mais a respeito da questão inicial entregamos a cada equipe uma roda gigante em MDF, régua e barbante com o propósito de fazê-los perceber que para além das relações descritas havia outras observações que poderiam ser também pensadas e apontadas a partir do material disponibilizado (Imagem 1). Tais reflexões pautaram-se em questionamentos relacionados ao movimento da roda gigante.

- Supondo que o movimento de rotação da roda seja uniforme e que tenha se iniciado quando um passageiro entrou e se sentou na cadeira, qual é a altura da cadeira em relação ao solo?

- Depois de quantas voltas essa altura se repete?

- Qual é a altura máxima da cadeira?

- Observando que entre a altura mínima e a altura máxima há várias alturas intermediárias que são atingidas duas vezes em cada volta, qual a medida dessas alturas intermediárias?

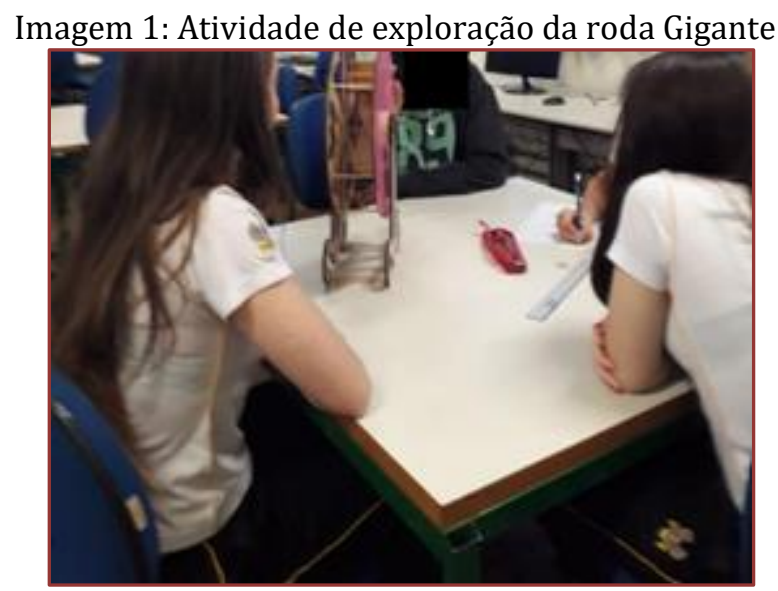

Fonte: As autoras

Com os materiais em mãos e, a partir dos questionamentos apresentados, cada grupo tentou pensar qual seria a melhor estratégia para obter informações necessárias a solução dos questionamentos propostos descrevendo as informações obtidas (dados) em seu caderno. A maioria dos grupos utilizou a princípio, a régua e o barbante e, a partir das medições realizadas registraram as informações que julgavam necessárias, estabelecendo com os dados obtidos a seguinte relação: altura x comprimento percorrido. Um grupo, no entanto, utilizou outra estratégia, tentando encontrar primeiro o ângulo deslocado a partir da subdivisão de $360^{\circ}$ por 2, 3, 4, 6, 8, etc. Apesar de, com a ideia terem claro que conseguiriam achar pontos sob a circunferência e, de efetuarem as divisões corretas, não conseguiram a princípio perceber que de alguma forma deveriam conciliar sua estratégia às medições relativas a altura correspondente a cada ângulo de deslocamento obtido. Tal fato fez com que os discentes se confundissem na descrição dos dados, contudo, após o auxilio do professor conseguiram fazê-lo assim como as demais equipes.

Como os parâmetros usados por esse grupo envolviam as medidas em ângulo e, tal informação seria relevante para o desenvolvimento das demais atividades, convidamos as equipes a socializarem suas conclusões com os demais colegas.

Para que a etapa seguinte - a do esboço do gráfico (IMAGEM 2) - fosse bem compreendida, solicitamos aos discentes que registrassem a altura e o comprimento percorrido ou o ângulo de deslocamento (os grupos ficaram livres para essa escolha) para 24 diferentes posições considerando duas voltas na roda gigante.

Em seguida, entregamos a cada equipe uma folha de papel quadriculado na qual deveriam fazer o esboço de um gráfico tendo como suporte suas reflexões, apontamentos e dados obtidos a partir das discussões promovidas até o momento. Cada uma das equipes deveria refletir a respeito dos dados descrevendo, a princípio quais seriam representados em cada um dos eixos do gráfico e, a partir da representação gráfica obtida, dizerem aos demais colegas o que poderiam afirmar a respeito do gráfico obtido, bem como se já haviam visto algo parecido.

A princípio, alguns grupos fizeram a representação dos dados no gráfico considerando apenas uma volta, o que fez com que chegassem a representação gráfica semelhante a de uma parábola com a concavidade voltada para cima. 
Nesses grupos fizemos o seguinte questionamento: se as pessoas derem mais de uma volta, ou se pensarmos em infinitas voltas a representação permanecerá essa ou se alterará? A partir da pergunta levantada todos os grupos conseguiram chegar ao esboço do gráfico de uma função periódica por meio de suas medições, simulações e dados obtidos.

Ressaltamos, a partir dos gráficos apresentados que, apesar de os grupos trabalharem com unidades diferentes: altura x comprimento percorrido ou altura x ângulo de deslocamento, ambos os esboços levaram a representações semelhantes que poderiam traduzir uma ideia. Perguntamos então aos grupos qual seria essa ideia? Sintetizaremos aqui na fala de uma das alunas a conclusão a que chegaram os discentes: "Se considerarmos além das voltas aqui representadas outras, isso é, se pensarmos em infinitas voltas, como se a roda gigante não parasse de girar, veremos que há algo que sempre se repete - um período ${ }^{14}$, por isso podemos dizer que esse é o esboço do gráfico de uma função periódica (ALUNA A)."

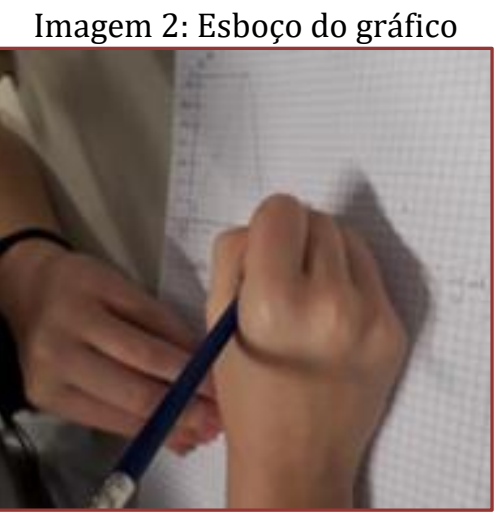

Fonte: As autoras

Após esse segundo momento de discussão, apresentamos aos alunos uma animação no Geogebra que mostrava exatamente qual seria a representação gráfica do movimento das cadeiras da roda gigante pensando-se na altura x ângulo de deslocamento em radianos. A imagem apresentada se fez necessária para estabelecermos duas discussões com relação aos conceitos trigonométricos que desejávamos ressaltar: a de radiano definido aqui como a medida do ângulo central que determina na circunferência um arco cujo comprimento é igual ao raio (experiência realizada pelos alunos com o auxílio da roda gigante e do barbante disponível aos discentes); bem como a de periodicidade procurando, a partir da animação apresentada, fazer com que os discentes percebessem que os pontos mais baixos do gráfico estavam representados nos valores múltiplos de 2 .

Com vistas a fazer com que os discentes compreendessem no ciclo trigonométrico a relação grau radiano, abordada posteriormente no Ensino Médio, fizemos uso de outro material manipulativo (IMAGEM 3) convidando-os a, partindo da manipulação de um círculo e de triângulos retângulos de papel e do conceito de simetria de rotação, responder aos seguintes questionamentos:

- Utilizando a simetria de rotação, determine quantos triângulos cujo ângulo de $30^{\circ}$ tem vértice no centro da circunferência trigonométrica e cujo ângulo de $60^{\circ}$ tem vértice na circunferência são necessários para percorrer todo o círculo?

- Utilizando a simetria de rotação, determine quantos triângulos cujo ângulo de $45^{\circ}$ tem vértice no centro da circunferência trigonométrica e cujo ângulo de $45^{\circ}$ tem vértice na circunferência são necessários para percorrer todo o círculo?

\footnotetext{
${ }^{14}$ As palavras período e periodicidade apresentadas na fala da aluna devem-se as discussões ocorridas nos pequenos grupos com a intervenção do professor que, buscou a formalização de conceitos e o refinamento da linguagem matemática a partir das ideias apresentadas pelos discentes. Contudo, a que se ressaltar que, apesar da não utilização dos termos matemáticos mais adequados, os discentes conseguiram vislumbrar no esboço do gráfico um padrão e, a seu modo descrevê-lo.
} 


\subsection{EDUCAÇÃO MATEMÁTICA COM AS ESCOLAS DA EDUCAÇÃO BÁSICA: INTERFACES ENTRE PESQUISAS E SALAS DE AULA}

- Utilizando a simetria de rotação, determine quantos triângulos cujo ângulo de $60^{\circ}$ tem vértice no centro da circunferência trigonométrica e cujo ângulo de $30^{\circ}$ tem vértice na circunferência são necessários para percorrer todo o círculo?

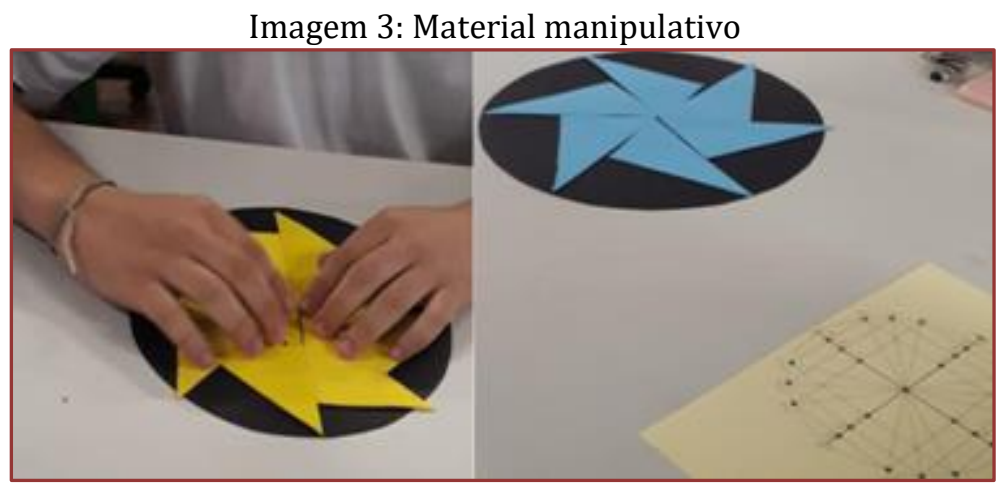

Fonte: As autoras

Partindo das informações obtidas por meio das questões acima apresentadas procuramos fazer com que os discentes encontrassem sob a circunferência trigonométrica os valores em graus e radianos correspondentes aos pontos obtidos - para isso, entregamos a cada discente um círculo trigonométrico que deveria ser preenchido por cada um deles (IMAGEM 3).

Durante a realização da atividade os discentes conseguiram visualizar que alguns pontos eram comuns a circunferência trigonométrica como é o caso de $180^{\circ}$ por ser esse valor múltiplo de $30^{\circ}$ e $60^{\circ}$, ou $360^{\circ}$ múltiplo de $30^{\circ}$, 45ํㅡ e 60․ Tal atividade fez-se necessária para que os alunos conseguissem, não só, verificar como esses valores estavam representados a circunferência trigonométrica, como também, pudessem estabelecer a relação dos conceitos estudados com os valores do seno, cosseno e tangente de $30^{\circ}$, 45ํㅡ e 60ำ vistos nos anos anteriores, com os múltiplos desses ângulos, pensando agora em todos os valores encontrados sobre a circunferência trigonométrica. Tais conceitos foram explorados a partir da utilização de material manipulativo disponível e do Software Geogebra.

Visando ainda, fazer o estudo dos sinais na circunferência trigonométrica exploramos, com o auxílio do software Geogebra, os eixos do seno e do cosseno comparando esses eixos com a representação já conhecida pelos discentes - a do sistema de coordenadas cartesianas, com vistas a fazer o estudo dos sinais dos valores do seno e cosseno de todos os pontos obtidos sobre a circunferência trigonométrica pensando no quadrante a que pertencem esses pontos.

Após esse estudo trabalhamos com os discentes o jogo - Mandala Trigonométrica (IMAGEM 4) com o intuito de retomar os conceitos abordados: valor de um arco em graus e radianos; valor do seno e do cosseno de um arco; descoberta de arcos correspondentes a partir dos valores do seno e do cosseno.

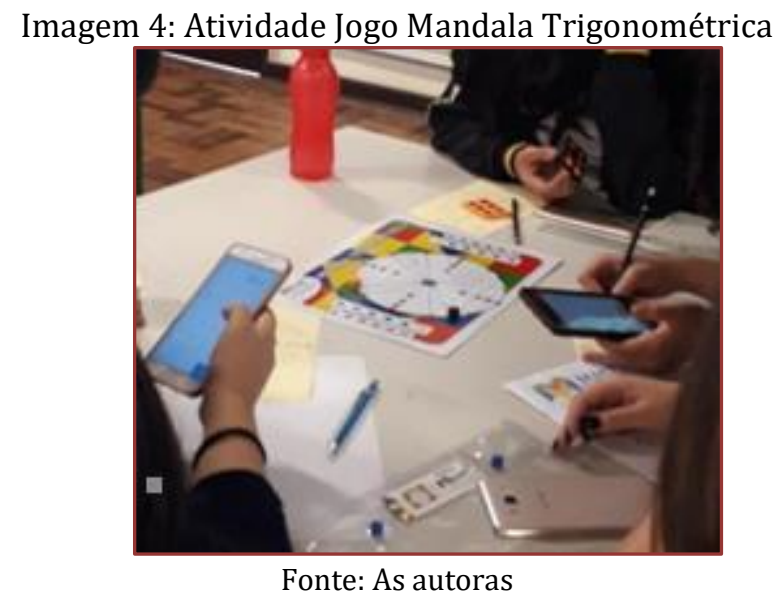


Para concluir as atividades apresentamos aos alunos fatos relacionados à história e a aplicabilidade da trigonometria estabelecendo com os discentes uma discussão a respeito da utilidade desses conceitos na solução de problemas ao longo da história, bem como de sua importância atual, visto que a trigonometria é hoje empregada em muitas áreas sendo assim seu estudo necessário e relevante.

\section{CONSIDERAÇÕES FINAIS}

A proposta apresentada neste trabalho mostra a importância do conceito de trigonometria para o desenvolvimento do raciocínio lógico-matemático e para a tomada de decisões quanto à análise de problemas do cotidiano, bem como alicerça a ideia de que o uso de materiais manipulativos e softwares como o Geogebra são de suma importância na promoção da aprendizagem, tendo-se em vista seu caráter dinâmico e sua intencionalidade.

Segundo os discentes que participaram da oficina a experiência foi valiosa e significativa, pois além de possibilitar uma visão geral a respeito do assunto que seria ainda abordado em sala de aula fez com que percebessem a relevância da trigonometria na solução de problemas.

A partir das análises realizadas com a aplicação das atividades, verificou-se que os discentes tiveram a oportunidade de refletir e verbalizar a respeito de questões envolvendo o valor de um arco em graus e radianos; valor do seno e do cosseno de um arco; descoberta de arcos correspondentes a partir dos valores do seno e do cosseno por meio de atividades manipulativas e do uso de Softwares. Atividades que levaram os discentes a perceberem o quanto o estudo da trigonometria foi relevante para a solução de problemas no decorrer da história da humanidade e ainda o é.

Nesse sentido, ao se trabalhar com uma estratégia de ensino diferenciada como a apontada neste trabalho, o professor busca mais do que apenas passar informações sobre o conteúdo, agrega às suas aulas fatores como, a capacidade do discente adquirir estratégias de resolução de problemas, planejamento de ações, desenvolvimento de cálculos mentais, pensamento lógico matemático, refinamento da linguagem matemática, bem como a socialização e interação com os demais alunos envolvidos.

Assim, este trabalho é uma sugestão ao profissional que deseja explorar o conteúdo de trigonometria de forma diferenciada, a partir de uma prática colaborativa, rica em processos que estimulem a interação dos alunos com o professor e com seus pares. Prática essa que visa à promoção da aprendizagem matemática de forma espontânea, participativa, permeada de discussões em grupo nas quais os erros e acertos nada mais são do que impulsionadores de novas aprendizagens.

\section{REFERÊNCIAS}

[1] Brasil, Ministério da Educação. Base Nacional Comum Curricular. Brasília: MEC/SEF, 2018.

[2] Brasil. Secretaria de Educação Básica. Orientações Curriculares para o Ensino Médio. Volume I. Secretaria de Educação Básica. - Brasília: MEC/SEB, 2006.

[3] Brasil. Ministério da Educação e Cultura. Parâmetros Curriculares Nacionais para o Ensino Médio: Matemática. Brasília: Ministério da Educação e Cultura, 1999.

[4] Costa, N. M. L da. Funções seno e cosseno: uma sequência de ensino a partir dos contextos do "mundo experimental" e do computador. São Paulo: PUC, 1997. 250 p. Dissertação (Mestrado) - Programa de Pós-Graduação em Ensino de Matemática, Pontifícia Universidade Católica de São Paulo, 1997.

[5] Mendes, I. A. O uso da história no ensino da matemática: reflexões teóricas e experiências. Belém: EDUEPA, 2001.

[6] Paraná, Secretaria da Educação do Estado do Paraná. Referencial Curricular do Paraná: princípios, direitos e orientações. Paraná: Secretaria da Educação, 2018.

[7] Quintaneiro, Wellerson. Representações e definições formais em trigonometria no Ensino Médio. Rio de Janeiro: UFRJ, 2010. 154 p. Dissertação (Mestrado) - Programa de Pós-Graduação em Ensino de Matemática, Instituto de Matemática, Universidade Federal do Rio de Janeiro, Rio de Janeiro, 2010. 


\section{Capítulo 14}

\section{Taxa de evasão dos cursos da URCA com as disciplinas de Matemática na grade curricular}

\section{Ana Josicleide Maia}

Aline Alves de Oliveira

Cibelle Teixeira de Oliveira

Ana Roberta Duarte Piancó

Resumo: A evasão no ensino superior é um fenômeno caracterizado pelo abandono do curso pelo aluno antes de sua formação. Por essa razão, é de fundamental importância ter conhecimento acerca da evolução da taxa de evasão nas instituições de ensino superior (IES). 0 objetivo do trabalho foi Analisar a taxa de evasão dos cursos da Universidade Regional do Cariri (URCA) com disciplinas de matemática na grade curricular. Tomou-se a relação do número de alunos evadidos e matriculados no período de 2016 a 2018. Os dados foram coletados no Departamento de Tecnologia e Informação (DTI) através do sistema Teseus. Os cursos com maior evasão média foram tecnólogo da construção civil (Juazeiro do Norte) e matemática (Campos Sales) com 11,1 e 10,95\% respectivamente, sendo 2018 o ano de maior evasão média e menor coeficiente de variação. 0 curso de ciências econômicas (Crato) verificou menor variação da evasão e engenharia de produção (Juazeiro do Norte) com menor média. 


\section{INTRODUÇÃO}

A evasão no ensino superior é um fenômeno caracterizado pelo abandono do curso pelo aluno antes de sua formação. Por essa razão, é de fundamental importância ter conhecimento acerca da evolução da taxa de evasão nas instituições de ensino superior (IES), tanto na administração pública quanto na privada, visto que, esse fenômeno constitui perdas sociais, acadêmicas e econômicas. Uma vez a par dessas informações, poder-se-á levantar e analisar as causas frequentes que induzem a evasão do discente e, assim, adotar medidas com vistas à redução da ocorrência desse problema. É relevante ressaltar que, o aumento no número de instituições de ensino superior (e, portanto, de vagas) observado nos últimos anos contribuiu para o aumento das taxas de evasão.

Desde a década de 1990 existe um problema que aflige as instituições de ensino superior, tanto públicas quanto privadas, bem como, preocupa as autoridades. Este problema é a evasão. O REUNI $(2007$, p.4) prever que a taxa máxima de evasão admitida na graduação seria de $10 \%$. Evasão é à saída do aluno de uma IES ou de um de seus cursos de forma temporária ou definitiva por qualquer motivo, exceto a diplomação (MARTINS, 2007, p. 29).

A evasão causa diversos problemas para as instituições e sucessivamente para a sociedade, pois deixam ociosos funcionários, professores, equipamentos, espaço físico, e novos profissionais para o mercado de trabalho deixam de ser formados. A evasão é uma fonte de desperdício do dinheiro público por afetando diretamente o resultado dos sistemas educacionais (SILVA FILHO et al., 2007).

A evasão universitária é um problema que atinge instituições do mundo inteiro e quaisquer cursos. Contudo, os maiores índices de abandono são observados no início da graduação: a evasão no primeiro ano de um curso universitário chega a ser três vezes maior que nos anos posteriores (PRIM; FÁVERO, 2013).

Reis (2012) catalogou as principais causas da evasão nos cursos de Engenharia ofertadas pelo CEFET/RJ, obtendo: falta de tempo para o estudo, pela necessidade de trabalhar; desmotivação para o estudo, em função do emprego de práticas tradicionais; falta de identificação do aluno com a área que está cursando; dificuldades de aprendizado (principalmente no ciclo básico); desempenho ruim nas avaliações iniciais; bons salários em outras áreas de conhecimento/ formação; dificuldade de adaptação à dinâmica do ensino superior, que é diferente daquela vivenciada no ensino médio; não atendimento das expectativas dos estudantes por parte do curso; falta de subsídio aos estudantes (financeiro, alimentar, etc.); ensinos fundamental e médio deficientes, principalmente em exatas; e, também, imaturidade ao escolher a carreira.

Hengles e Pereira (2017) em seu estudo verificaram que há uma preocupação recente com a evasão, pois é legítimo observar um aumento significativo no número de publicações nos últimos três anos. Foi possível verificar vários motivos relacionados ao abandono por parte dos estudantes e as estratégias para sua permanência, verificando a peculiaridade de cada caso.

0 índice médio de evasão em 25 cursos avaliados em uma pesquisa foi de $38,2 \%$. Os resultados apontam que os menores índices de evasão, no período analisado, ocorreram nos cursos da área de Ciências da Saúde $(19,6 \%)$ e os maiores nos cursos das áreas de Ciências Exatas e da Terra (58,6\%), Engenharia (41,0\%), e Linguística, Letras e Artes (45,9\%) (DAVOK; BERNARD, 2016).

Os resultados de uma pesquisa realizada por Fritsch (2015) mostraram que o percentual de evasão fica em torno de 5 a 10\%, sendo a evasão média geral de 7,49\%. Percebeu-se que a evasão tende a ser maior em disciplinas com maiores taxas de reprovação e que as taxas de evasão estão associadas, principalmente, a um conjunto de cinco variáveis: a média de desempenho do aluno no grau parcial; média geral da turma ao final do semestre; o percentual de reprovação da turma ao final do semestre, associado também ao grau de dificuldade da disciplina; a quantidade de alunos por e a média de créditos concluídos.

Segundo Lobo (2012) a taxa anual média de evasão no ensino superior no Brasil, manteve-se na casa dos $22 \%$ nos últimos anos, considerando a modalidade presencial de ensino. 0 Ceará apresentou um índice de evasão de $19 \%$ em 2010, chegando a $23,4 \%$ em 2014. A taxa de evasão é um indicador que analisa o percentual de acadêmicos que se evadiram da universidade num determinado período.

De acordo com Silva (2017, p.08)

A retenção e a evasão no curso de engenharia de alimentos da UFPB se concentra nos dois primeiros anos do curso, acentuando-se no primeiro ano, após reprovações dos estudantes, pincipalmente nas disciplinas da área das ciências exatas, dificuldade financeira para o estudante se manter na 
instituição, incerteza quanto ao mercado de trabalho, bem como falta de afinidade com o curso e metodologia aplicada.

Uma pesquisa com 63 estudantes evadidos do campus Crateús da Universidade Federal do Ceará (UFC) no intuito de analisar as causas da evasão por meio de uma análise fatorial exploratória e de uma confirmatória. Após a análise é possível confirmar os principais motivos desse evento, como a frustração pelo desempenho acadêmico, alteração da saúde mental, a falta de vontade de cursar a graduação escolhida, a falta de apoio familiar, a falta de comprometimento com a graduação (OLIVEIRA et al., 2019)

Inserida na Macrorregião Centro-Sul encontrasse a Universidade Regional do Cariri (URCA), uma Instituição de Ensino Superior pertencendo ao estado do Ceará, que será objeto de estudo deste trabalho.

A URCA possui um raio de atuação amplo que envolve vários municípios do sul cearense, além de atuar em outros estados circunvizinhos do Ceará. A instituição possui unidades ou campus nas cidades de Crato, onde funciona a sede administrativa, nos municípios de Juazeiro do Norte, Missão Velha, Iguatu, Campos Sales e Santana do Cariri, onde funciona o Museu de Paleontologia. Atualmente a URCA possui 18 cursos, entre bacharelados, licenciaturas e tecnólogos, destes 7 tem a matemática como disciplina obrigatória na grade curricular.

Sendo assim, o objetivo do trabalho é analisar a taxa de evasão dos cursos da Universidade Regional do Cariri - URCA com disciplinas de matemática na grade curricular no período de 2016 a 2018.

Para alcançar este objetivo, utilizou-se a seguinte metodologia: os dados da pesquisa foram coletados no Departamento de Tecnologia da Informação - DTI da Universidade Regional do Cariri - URCA. Tomou-se o número de alunos matriculados e evadidos de cada curso e por semestre da URCA. A taxa de evasão escolar é a relação da quantidade dos alunos evadidos e os alunos matriculados. Assim, o cálculo do percentual de alunos evadidos foi realizado anualmente através da equação:

$$
T E v=\frac{N^{\mathrm{o}} \text { de alunos evadidos }}{N^{\mathrm{o}} \text { de alunos matriculados }} * 100
$$

Onde: Evadidos = desistente + em abandono + transferido

Para análise da taxa de evasão foi utilizado o excel para calcular e apresentar os dados. A tabela 01 apresenta as seguintes medidas: média, desvio padrão e coeficiente de variação dos cursos e dos anos e gráfico 01 apresenta o percentual de evasão dos cursos nos devidos anos.

Tabela 01: Taxa de Evasão e medidas estatísticas dos cursos de graduação da URCA com as disciplinas de matemática na grade curricular período de 2016 a 2018

\begin{tabular}{|c|c|c|c|c|c|c|}
\hline \multirow[b]{2}{*}{ CURSOS } & \multicolumn{3}{|c|}{ ANOS } & \multicolumn{3}{|c|}{ MEDIDAS } \\
\hline & 2016 & 2017 & 2018 & Média & $\begin{array}{l}\text { Desvio } \\
\text { padrão }\end{array}$ & CV $(\%)$ \\
\hline Ciências Econômicas (Crato) & 7.74 & 7.13 & 7.48 & 7,45 & 0,30 & 4,09 \\
\hline Ciências Econômicas (Iguatu) & 6.32 & 7.33 & 8.32 & 7,32 & 1,00 & 13,66 \\
\hline Tec. da Cons. Civil (Juazeiro do Norte) & 11,86 & 10,39 & 11,06 & 11,10 & 0,74 & 6,64 \\
\hline Eng. de Produção (Juazeiro do Norte) & 7,60 & 6,21 & 7,82 & 7,21 & 0,87 & 12,10 \\
\hline Física (Juazeiro do Norte) & 9,19 & 10,71 & 9,41 & 9,77 & 0,83 & 8,45 \\
\hline Matemática (Juazeiro do Norte) & 11,31 & 6,69 & 10,82 & 9,61 & 2,54 & 26,43 \\
\hline Matemática (Campos Sales) & 7,25 & 15,22 & 10,45 & 10,97 & 4,01 & 36,58 \\
\hline MEDIDAS & 2016 & 2017 & 2018 & & & \\
\hline Média & 8,75 & 9,10 & 9,34 & & & \\
\hline Desvio Padrão & 2,12 & 3,24 & 1,48 & & & \\
\hline CV (\%) & 24,22 & 35,61 & 15,88 & & & \\
\hline
\end{tabular}

Fonte: DTI da URCA (2018)

Comparando com outros estudos, Davok e Bernard (2016) e Lobo (2012), as taxas de evasão dos cursos analisados na URCA são baixas, variando de 7,21 a 11,10. 0 curso de Tecnologia da Construção Civil e o curso de matemática de Campos Sales apresentaram maiores médias da taxa de evasão, enquanto o curso de Engenharia da Produção apresenta a menor média. Porém, analisando a média da taxa de evasão por 
ano, esta tem se elevado, em 2016 a média era de 8,75 e passou para 9,34 em 2018, no entanto o ano de 2017 foi o que obteve maior coeficiente de variação. 0 curso de ciências econômica do Crato verificou-se menor variação no período de 2016 a 2018.

Como já relatado alguns fatores podem influenciar o aumento da taxa de evasão, alguns deles são: deficiência da educação básica, para o MEC/SESU (1997)a precária formação escolar de muitos acadêmicos, devido à deficiência do sistema de ensino básico do país, é fator determinante das dificuldades por eles enfrentadas. Segundo o INEP/MEC (2017), 70\% dos alunos do ensino médio tem nível insuficiente em matemática. Outro fator relevante é o nível de renda dos alunos, os alunos com maiores necessidades socioeconômicas sentem dificuldades em permanecerem na universidade quando não há programas de auxílio, de acordo com os dados do questionário socioeconômico da URCA (PROPLAN 2018), 66,73\% dos alunos tinham renda de até 0,5 salário mínimo, porém a universidade possui políticas de assistência estudantil, esta conta com restaurante universitário, residência universitária e bolsas de estágio, monitoria, extensão e pesquisa. Por conta da baixa renda, mais de 50\% dos estudantes trabalhavam em alguma atividade (PROPLAN, 2018), notasse que uma parte expressiva de estudantes são oriundos de famílias pobres e que buscam conciliar educação e trabalho para se manter, o que para o MEC/INEP (2009), também é considerado um fator relevante para a evasão.

Gráfico 01: Taxa de Evasão dos cursos de graduação da URCA com as disciplinas de matemática na grade curricular período de 2016 a 2018

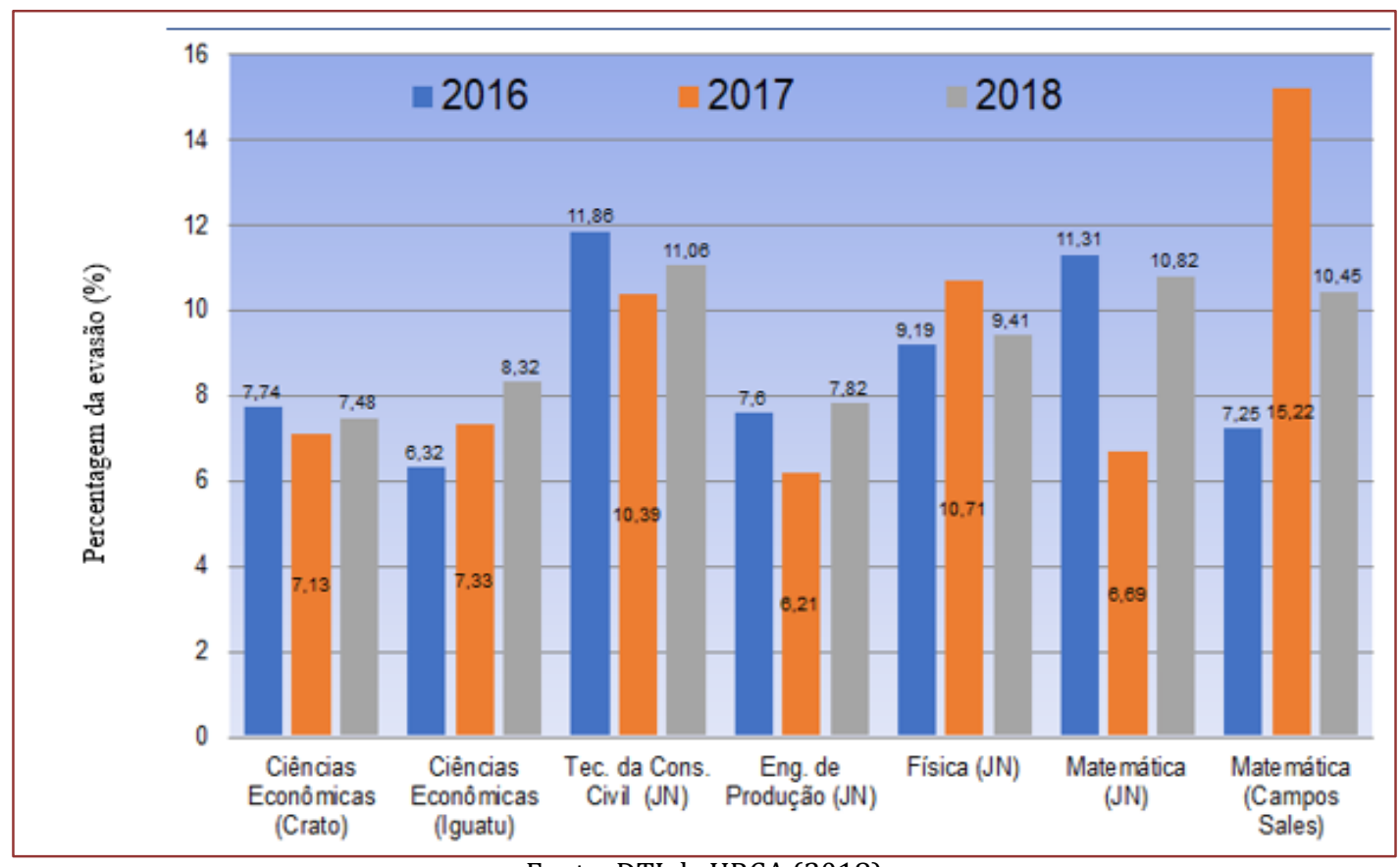

Fonte: DTI da URCA (2018)

Outro fator relevante para o aumento da taxa de evasão é o difícil acesso à universidade, alguns acadêmicos desistem por não ter condições de arcar com os gastos provenientes de transporte, outros por não terem tempo para as viagens rotineiras. (KAFURI e RAMON, 1985). A URCA é uma instituição que recebe estudantes de diversos estados do Nordeste, bem como de outras cidades do Ceará, assim esses estudantes não possuem renda para se transferirem para as cidades que possuem campus da universidade proporcionando deslocamentos dos mesmos para esse campus. Desta forma, o transporte escolar $(38,19 \%)$ é o meio mais utilizado pelos alunos para se deslocarem até a URCA, devido as distancias entre as cidades muitos municípios acabam cedendo transportes para os estudantes, da mesma forma que alguns criam associações de universitários para tal finalidade. 


\section{CONSIDERAÇõES FINAIS}

As taxas de evasão dos cursos analisados na URCA foram baixas enquanto o curso de tecnólogo da construção civil e o ano de 2018 apresentaram maior taxa de evasão.

\section{AGRADECIMENTOS}

Os agradecimentos, a Pró-Reitoria de planejamento e avaliação (PROPLAN) e o setor de informática (DTI) da Universidade Regional do Cariri - URCA.

\section{REFERÊNCIAS}

[1] Davok, D, F; Bernard, R. P.Avaliação dos índices de evasão nos cursos de graduação da Universidade do Estado de Santa Catarina - UDESC. Avaliação, Campinas; Sorocaba, SP, v. 21, n. 2, p. 503-521, jul. 2016. Doi: http://dx.doi.org/10.1590/S1414-40772016000200010

[2] Fritsch, R.A problemática da evasão em cursos de graduação em uma universidade privada. 37a Reunião Nacional da ANPEd - 04 a 08 de outubro de 2015, Ufsc - Florianópolis.

[3] Hengles, A. C. V; Pereira, M. V. Evasão e Permanência em Instituições de Ensino Superior. Rev. Elet. Cient. Uergs, v.3, n.1, p.95-128, 2017. Doi: http://dx.doi.org/10.21674/2448-0479.31.95-128.

[4] Kafuri, R.; Ramon, S. P. 1o Grau - casos e percalços: pesquisa sobre evasão, repetência e fatores condicionantes. Goiânia: UFMG, 1985.

[5] Lobo, M. B. C. M. Panorama da evasão no ensino superior brasileiro: aspectos gerais das causas e soluções. Associação Brasileira de Mantenedoras do Ensino Superior, 25, 2012.

[6] Martins, C. B. N. Evasão de alunos nos cursos de graduação em uma instituição de ensino superior. 2007.102 f. Dissertação (Mestrado Administração) - Fundação Dr. Pedro Leopoldo, Pedro Leopoldo, 2007. Disponível em: <http://www.fpl.edu.br/2012/media/ pdfs/05.mestrado/dissertacoes_2007/dissertacao_cleidis_beatriz_nogueira_ martins_2007.pdf>. Acesso em: 16 jun 2015.

[7] Mec/Sesu. Comissão Especial de Estudos sobre a Evasão nas Universidades Públicas Brasileiras. Brasília: Andifes/Abruem/Sesu/Mec. 1997.

[8] Mec/Inep. Resumo Técnico: Censo da Educação Superior 2007. Brasília-DF. 2009.Disponível em : <http://www.inep.gov.br> Acesso em: 13 abril de 2019.

[9] Oliveira. C. H. M de; Santos, F. R. T; Leitinho, J. L. Farias. L. G. A. T. Busca dos fatores associados à evasão: um estudo de caso no Campus Universitário da UFC em Crateús. Rev. Inter. Educ. Sup. Campinas, SP. v.5 1-23, 2019

[10] Prim, A. L.; Fávero, J. D. Motivos da evasão escolar nos cursos de ensino superior de uma faculdade na cidade de Blumenau. E-Tech: Tecnologias para Competitividade Industrial, Florianópolis, n. Especial Educação, p. 53-72, 2013.

[11] Proplan. Pró- reitoria de Planejamento e Avaliação. Questionário Socioeconômico. Universidade Regional do Cariri.. Crato, 2018.

[12] Reis, V. W; Cunha, P. J. M; Spritzer, I. M. P. A. Evasão no ensino superior de Engenharia no Brasil: um estudo de caso no Cefet/RJ. Disponível em: Acesso em: 4 dez 2016.

[13] Reuni - Restruturação e Expansão das Universidades Federais. Diretrizes gerais. Brasília: Sesu/Mec, 2007. Disponível em: <http://portal.mec.gov. br/sesu/arquivos/pdf/diretrizesreuni.pdf>. Acesso em: 24 agosto 2017.

[14] Silva, G. S. da. Retenção e evasão no ensino superior no contexto da expansão: o caso do curso de engenharia de alimentos da UFPB. Dissertação (mestrado). João Pessoa, 2017, 124f.

[15] Silva Filho, R. L. L. et al. A evasão no ensino superior brasileiro. Caderno de Pesquisa, São Paulo, v. 37, n. 132, p. 641-659, dez. 2007. Disponível em: <http://www.scielo.br/pdf/cp/v37n132/a0737132.pdf>. Acesso em: 02 jan. 2015. 


\section{Capítulo 15}

A utilização do aplicativo Geogebra para smartphone na construção de gráficos de situações-problemas envolvendo juros simples e compostos

\section{Décio de Oliveira Gröhs \\ Michael Araújo de Oliveira \\ Gilberto Francisco Alves de Melo}

Resumo: Este relato de experiência faz parte de duas pesquisas de mestrado envolvendo aplicativos de dispositivos móveis na educação. A atividade foi realizada em novembro de 2018 com duas turmas do 2. ${ }^{\circ}$ ano do Ensino Médio, com 25 alunos em Boca do Acre AM e 11 alunos em Cruzeiro do Sul - AC. Utilizamos como referencial teórico Pais (2010), Skovsmose (2001) e Kistemann Junior (2011). A proposta teve como objetivo principal a utilização do aplicativo GeoGebra para smartphone com o propósito de levar os alunos a compreender e construir os gráficos de situações-problemas, com a finalidade de obter visualização gráfica e tomar decisões. Os resultados mostraram que o uso do GeoGebra contribuiu significativamente para a compreensão dos conceitos de juros simples e compostos, gerando diálogos e socialização entre os grupos de alunos durante o desenvolvimento das atividades.

Palavras-chave: Matemática Financeira; GeoGebra; Gráfico; Smartphone. 


\section{INTRODUÇÃO}

Atualmente, nossas salas de aula são compostas por uma geração nascida na era digital, que possui seus smartphones conectados à rede mundial de computadores, possuindo informação em tempo real com aplicativos cheios de notificações de redes sociais e jogos digitais. Essa inovação tornou a vida cotidiana dos nossos alunos dinâmica e interativa. Assim, ensinar nesse contexto é um desafio, por isso,

para tratar das potencialidades e dos desafios decorrentes do uso educacional das tecnologias digitais, destacamos a necessidade de refletir também a propósito das novas competências exigidas pela sociedade da informação, onde o interesse está mais particularmente voltado para aqueles referentes ao fazer pedagógico (Pais, 2010, p. 14).

Durante as aulas do Mestrado Profissional em Ensino de Ciências e Matemática da disciplina de Ensino da Matemática e suas Metodologias (2º sem/2018) surgiu o desafio de aproximar os estudos teóricos e a prática de ensino, com a finalidade de melhorar o trabalho em sala de aula. Para isso, juntamos duas pesquisas que possuem um objeto de estudo em comum, ou seja, o uso da tecnologia em sala de aula. Nos debruçamos sobre teóricos que tratavam da temática de educação financeira e tecnologias da informática na escola. Optamos como aporte teórico Pais (2010), que trata de algumas questões referentes ao uso da informática na educação escolar, Skovsmose (2001), que trata da Educação Matemática Crítica, e Kistemann Junior (2011), que trata as questões das ações do indivíduo-consumidor inserido em uma sociedade de consumo líquido-moderna ${ }^{15}$.

Como procuramos atividades que se aproximassem da vida cotidiana dos alunos, escolhemos como tema os juros simples e compostos. Acreditamos que a partir da inserção das tecnologias digitais no ambiente escolar, o aluno poderá ser o construtor de seu conhecimento, assumindo papel ativo e reflexivo durante o processo de aprendizagem, sendo o GeoGebra um grande facilitador na construção de gráficos em relação aos juros simples e compostos para tomada de decisões.

A proposta proporcionou maiores resultados e visões sobre o trabalho, uma vez que aplicados em lugares diferentes, abriu um leque de discussões sobre como pode ser desenvolvido em sala de aula, além do mais importante que é, justamente, o desdobramento no processo de ensino e aprendizagem de um conteúdo matemático com o uso de um aplicativo digital.

\section{FUNDAMENTOS TEÓRICOS E METODOLÓGICOS}

Pensando na realidade da sala de aula, escolhemos duas turmas do 2.ํano do Ensino Médio da rede pública de ensino, uma delas com 25 alunos situada no município de Boca do Acre - AM, na Escola Estadual Coronel José Assunção; e outra turma com 11 alunos no município de Cruzeiro do Sul - AC, na Escola Estadual Anselmo Maia de Carvalho. A distância por via terrestre entre os municípios é de aproximadamente $854 \mathrm{~km}$.

A aplicação ocorreu, simultaneamente, nos dois municípios, resultando em uma prática de três dias que foi dividida conforme o Quadro 1:

Quadro 1 - Cronograma da aplicação

\begin{tabular}{|c|c|}
\hline Dia & Prática \\
\hline $17 / 11 / 18$ & $\begin{array}{l}\text { - } \quad \text { Conceitos iniciais de Matemática Financeira; } \\
\text { Demonstração da diferença entre juros simples e compostos; } \\
\text { Aplicação da Atividade 1; }\end{array}$ \\
\hline $18 / 11 / 18$ & $\begin{array}{l}\text { Demonstração do Geogebra; } \\
\text { - } \quad \text { Criando gráficos a partir de funções do } 1^{\circ} \text { e e } 2^{\circ} \text { graus; } \\
\text { Construindo funções a partir de situações-problemas envolvendo juros; }\end{array}$ \\
\hline $19 / 11 / 18$ & $\begin{array}{l}\text { Feedback das aulas dos dias } 17 \text { e 18; } \\
\text { - } \quad \text { Aplicação da Atividade 2; }\end{array}$ \\
\hline
\end{tabular}

Fonte: Elaborado pelos autores

\footnotetext{
${ }^{15}$ Para Kistemann Junior (2011) o termo "sociedade líquido-moderna", é relativo a uma sociedade que manifesta alguns atributos: o consumo de massas; a moda em velocidade de progressão geométrica; mercadorias descartáveis; sentimento de insaciabilidade; o indivíduo-consumidor como seu personagem central.
} 
Pelo contingente de estudantes atendidos nos dois lócus, para a realização das atividades os alunos de Boca do Acre - AM foram divididos em grupos de cinco e os de Cruzeiro do Sul - AC foram divididos em duplas com a finalidade de criar debates e socialização do conhecimento adquirido, em que os pesquisadores assumiam um papel de articuladores no momento das atividades. De acordo com Moran et al. (2000, p. 71),

o docente inovador precisa ser criativo, articulador e, principalmente, parceiro de seus alunos no processo de aprendizagem. Nesta nova visão, o professor deve mudar o foco de ensinar para reproduzir conhecimento e passar a preocupar-se com o aprender e, em especial, o "aprender a aprender", abrindo caminhos coletivos de busca e investigação para a produção do seu conhecimento e do seu aluno.

No primeiro dia, explicamos os conceitos iniciais de Matemática Financeira, tais como: o que são juros, o contexto de capital, o montante, taxa de juros, as diferenças entre os juros simples e o composto tocante ao montante. Após as demonstrações aplicamos a Atividade 1, que continha duas questões solicitando o cálculo do montante nos regimes de capitalização simples e compostas. Para tal, foi solicitado aos alunos formarem os grupos/duplas e utilizarem a calculadora de seus smartphones.

Organismos internacionais, como a Organização para Cooperação do Desenvolvimento Econômico (OCDE), vêm acentuando a importância da Educação Financeira como promotora de inclusão social, haja vista as estatísticas alarmantes a respeito do percentual de endividados ${ }^{16}$ em países em desenvolvimento.

Procuramos propor uma atividade sob a perspectiva crítica e reflexiva, mediante um problema a ser investigado, relacionado a um possível evento vivenciado por uma pessoa comum, em que os alunos estavam no controle do processo educacional, no qual, de acordo com Skovsmose (2001), em um currículo crítico, colocamos princípios aparentemente objetivos e neutros para a estruturação de uma nova perspectiva, pois buscamos revelar tais princípios como algo carregado de valores.

Compreendemos que deve haver conciliação entre o Ensino de Matemática e a Educação Financeira, pois, de uma simples transação financeira, como a compra e/ou venda de produtos até atingir as análises complexas de ativos financeiros, o ensino de matemática pode atuar como mecanismo imprescindível na tomada de decisões.

Nesta direção, concordamos com Hoffman e Moro (2011) quando defendem:

Ainda que para as transações mais frequentes a matemática elementar seja suficiente, seu uso cotidiano para a tomada de decisões econômica - a exemplo das compras a prazo - ainda é bastante limitado, fazendo-se acompanhar, muitas vezes, de endividamento. Daí a importância da conciliação entre a Educação Matemática e Educação Financeira, sobretudo no esforço de (a) promover a aplicabilidade do conhecimento matemático escolar, garantindo-lhe relevância, e (b) conferir significados econômicos aos problemas matemáticos e vice-versa, explorando-se bidireccionalmente a importância do contexto na construção de sentido e na solução de problemas (Hoffman; Moro, 2011, p. 08).

A partir dessa concepção, avançamos os procedimentos metodológicos no segundo dia, apresentando-lhes a interface do GeoGebra e partes importantes, como a entrada de dados, parte gráfica e algébrica, além da parte dos comandos (ferramentas e funções), o que proporcionou maior desenvoltura na utilização do aplicativo por parte dos alunos. Com isso, mostramos como construir gráficos do primeiro e do segundo grau, com e sem intervalo de valores de " $x$ ", justamente com o intuito dos alunos saberem utilizar esse recurso para definir melhores resultados nas questões que compõem a segunda atividade. Para isso, tivemos que transformar a equação que determina o montante do regime de capitalização de juros simples e composto em uma função da qual o tempo é a variável.

\footnotetext{
${ }^{16}$ No Brasil, segundos dados levantados em novembro de 2018 na Pesquisa de Endividamento e Inadimplência do Consumidor (Peic), apurada pela Confederação Nacional do Comercio de Bens, Serviços e Turismo (CNC), mostra que a proporção de famílias com dívidas no cheque pré-datado, cartão de crédito, cheque especial e carnê de loja é de 60,3\%.
} 
Depois de longos exemplos e treinos no GeoGebra, partimos para a atividade cujo objetivo era possibilitar ao aluno se questionar sobre qual seria a melhor opção a ser tomada para que gerasse menos juros, e consequentemente, o montante menor. De modo específico, a atividade solicitava uma resposta dissertativa para uma situação-problema que envolvia taxa de juros com tempo distinto em um capital igual para as duas possibilidades. Uma das situações focalizou o regime de capitalização simples e, a outra o regime de capitalização composta.

O aplicativo foi o protagonista dessa questão, uma vez que o intuito era encontrar a resposta dessa situação interpretando o gráfico gerado pelos comandos dos próprios alunos, sem ter a necessidade de cálculos matemáticos. E, com um sentimento de ter atingido o objetivo, parcialmente, encontramos respostas que foram condizentes com a expectativa, além dos comentários e o semblante de compreensão e motivação por boa parte dos alunos.

\section{DESENVOLVIMENTO DA ATIVIDADE}

No primeiro dia de aplicação, foi proposta aos estudantes a resolução da primeira atividade que consistia em duas questões envolvendo uma situação-problema. Nessa atividade, eles poderiam usar a calculadora de seus smartphones e colocarem o passo a passo do raciocínio, construído com a finalidade de apurarmos os erros e os acertos do cálculo desenvolvido.

Ressaltamos a importância da Educação Financeira e de ter a Matemática como ferramenta na construção de saberes com a finalidade de se tornarem agentes críticos e reflexivos. Durante a explanação sobre os conceitos básicos de Matemática Financeira (juros, capital, montante, taxas), criamos um ambiente de socialização e debates acerca da educação financeira, no qual os (as) alunos (as) poderiam expor situaçõ es vivenciadas por eles ou por seus familiares e conhecidos.

Na atividade 1, propomos na primeira questão o seguinte: Qual o montante produzido por um capital de $R \$$ 2.500,00 aplicado à taxa de 1,7\% ao mês durante 6 meses, nos regimes de capitalização simples e composto? A segunda questão era: Um capital de $R \$ 30.000,00$ aplicado à taxa de 0,99\% ao mês, durante 5 anos, produzirá qual montante nos regimes de capitalização simples e composto? A seguir, podemos ver alguns exemplos do desenvolvimento de situações-problemas dos estudantes de ambas cidades conforme Figuras 1 e 2 :

Figura 2 - Atividades desenvolvidas por um grupo de estudantes de Boca do Acre (imagem esquerda) e de Cruzeiro do Sul (imagem direita)

\begin{tabular}{|l|l|}
\hline SIIMPLES & \multicolumn{1}{|c|}{ composto } \\
\hline$m=c(1+i \cdot n)$ & $m=c(1+i)^{n}$ \\
$m=2500+(1+0,017.6)$ & $m=2500(1+0,017)^{6}$ \\
$m=2500+(1+0,102)$ & $m=2500(1,017)^{6}$ \\
$m=2500,1,102$ & $m=2500 \cdot 1.1064$ \\
$m=2756$ & $m=2766$ \\
\hline
\end{tabular}

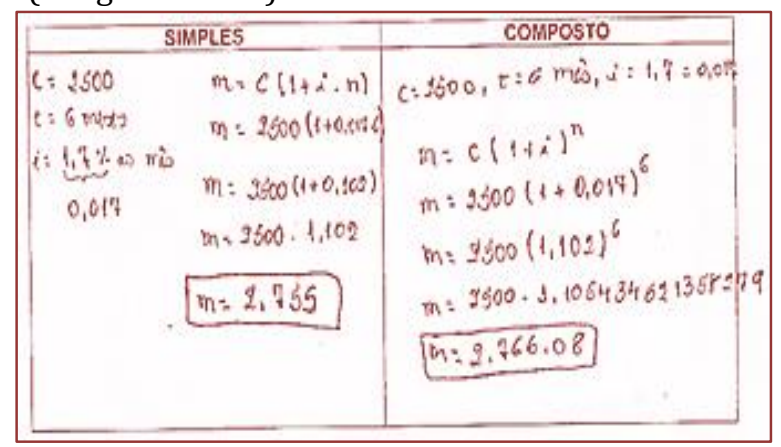

Fonte: Dos autores 
Figura 3 - Atividades desenvolvidas por um grupo de estudantes de Boca do Acre (imagem esquerda) e de Cruzeiro do Sul (imagem direita)
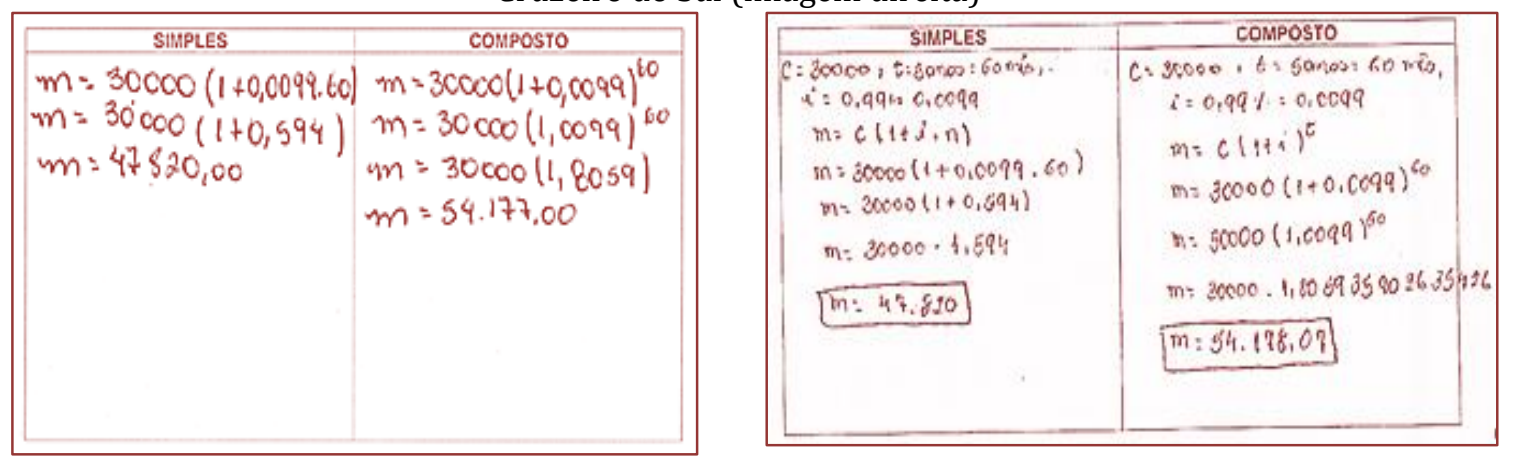

Fonte: Dos autores

Antes de usarmos as tecnologias digitais em sala de aula, realizamos uma breve reflexão sobre o porquê e para que estamos utilizando esse recurso, pois de acordo com Palfrey e Gasser (2011, p. 276) "o uso da tecnologia no ensino não faz sentido se for apenas porque achamos que é "legal". [...] Devemos descobrir como o uso das tecnologias pode dar suporte aos objetivos pedagógicos". Portanto, é necessária uma reflexão prévia sobre a proposta de uso desta ferramenta. Como diz Costa (2012, p. 71) "assim como os recursos mais tradicionais, como por exemplo, livro, retroprojetor, vídeo; o computador não pode ser usado apenas para motivar os estudantes a fazê-los participar mais ativamente no trabalho escolar."

Sempre atentamos com os alunos, o fato de que o uso do aplicativo em questão não é um "facilitador" na resolução dos exercícios, muito menos servirá como uma "varinha mágica" onde todos os conceitos de matemática financeira serão construídos. Por sua vez, eles servem apenas como ferramentas para auxiliar a reflexão dos conteúdos abordados. De acordo com Santos (2011, p. 42), "o emprego da informática não tem como objetivo único facilitar a resolução de um exercício ou possibilitar a visualização mais ampla de um gráfico, por exemplo". Além de oferecermos uma aprendizagem envolvida com a tecnologia digital, também temos que formar seres capazes e preparados para viver, agir e refletir no mundo modernizado em que o aparato tecnológico ganhou espaço e ampla divulgação.

Na Atividade 2 (Figura 3), a proposta era que eles desenvolvessem uma resposta dissertativa do motivo da escolha do tipo de capitalização que eles escolheriam se vivenciassem a seguinte situação proposta:

Figura 4 - Atividade 2 para os alunos analisarem com o uso do GeoGebra

Analise a seguinte situaçăo:
Alberto quer comprar um carro zero $\mathrm{km}$, o veiculo pretendido custa $\mathrm{R} \$ 50.000,00$, porém ele tem duas opções:
Opçäo 1 - Financiamento na concessionária, parcelado em 60 vezes, à taxa de $0,8 \%$ ao mês no regime de
capitalização composta.
Opçäo 2 - Empréstimo pessoal, parcelado em 48 vezes, à taxa de $2,3 \%$ ao mês, ao regime de capitalização
simples.
Utilizando o GeoGebra, verifique qual a opçăo mais vantajosa para ele e escreva com suas palavras o motivo
da escolha da opção.

Fonte: Elaborada pelos autores

Nesta atividade, auxiliamos os estudantes a construírem seus gráficos com os seus respectivos intervalos de tempo (eixo x) no GeoGebra para analisarem o montante (eixo y). Foram criadas as duas funções, desconsiderando as unidades de milhar (Quadro 3), pois o objetivo era obter uma análise visual e se fosse utilizado o capital inicial de $\mathrm{R} \$ 50.000,00$, ficaria muito complicado obter tal análise visual na tela do smartphone (Figura 4). 
Quadro 2 - Funções construídas para a análise no GeoGebra

\begin{tabular}{|c|c|}
\hline Opção 1 & Opção 2 \\
$\mathrm{M}=5(1+0,0008)^{\mathrm{x}}$ & $\mathrm{M}=5(1+0,023 \mathrm{x})$ \\
Com intervalo de $1 \leq \mathrm{x} \leq 60$ & Com intervalo de $1 \leq \mathrm{x} \leq 48$ \\
\hline \multicolumn{2}{|c|}{ Fonte: Elaborado pelos autores }
\end{tabular}

Figura 5 - Gráficos construídos no GeoGebra pelos estudantes

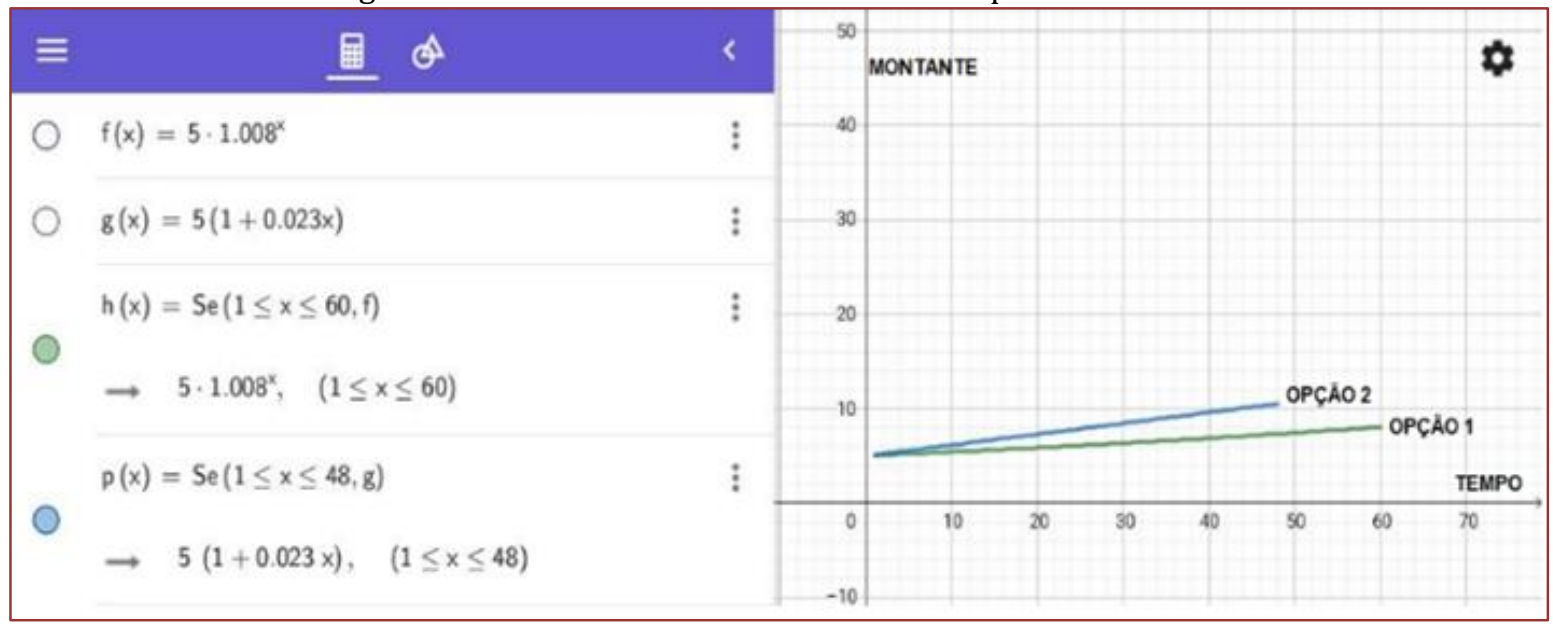

Fonte: Dos autores

Com o gráfico construído no GeoGebra, deixamos as equipes discutirem sobre suas escolhas. Neste momento percebemos que os estudantes não encontraram dificuldade na interpretação dos gráficos.

Após as discussões realizadas, solicitamos que escrevessem o motivo de suas escolhas, a resposta de um grupo de cada escola foi transcrita no Quadro 3 para melhor compreensão.

Quadro 3 - Transcrição das respostas de um dos grupos de Boca do Acre e de um dos grupos de Cruzeiro do Sul

Boca do Acre: Optamos pela função composta pois nos oferece menor valor final e quantidade de tempo maior para a efetuação do pagamento.

Cruzeiro do Sul: De acordo com os resultados realizados no GeoGebra, pode-se observar que o regime de capitalização composta foi mais vantajoso nessa situação que o regime de capitalização simples, sendo este com uma menor elevação de juros.

\section{Fonte: Dos autores}

Como podemos perceber, a resposta dos alunos apontava para o mesmo resultado: o problema envolvendo juros composto era mais vantajoso naquela situação. Ao final dessa atividade, discutimos os resultados obtidos pelos grupos com a finalidade de socializar o conhecimento. Durante a discussão, observamos que as respostas foram similares.

\section{CONSIDERAÇÕES FINAIS}

As atividades realizadas nas duas escolas com a mediação do aplicativo GeoGebra cumpriu com os objetivos propostos. De fato, na medida em que os estudantes refletiram e analisaram as situaçõesproblemas proposta nas atividades, mobilizaram seus conhecimentos prévios e estratégias na perspectiva de tomada de decisão.

Na atividade proposta na Figura 3, os estudantes conseguiram realizar a leitura e interpretaram o gráfico em relação aos dois sistemas de capitalização para a tomada de decisões, não apresentando dificuldades. Apesar do uso da calculadora não ser o foco da nossa atividade, foi diagnosticado durante as atividades, que alguns estudantes apresentaram dificuldades em relação ao uso da mesma, principalmente na construção e resolução de expressões numéricas. Isso demonstra que o uso desta da calculadora precisa de maior relevância nas salas de aula para que, no mínimo, o aluno saiba entender e manusear a ferramenta com prontidão, a fim de desenvolver o pensamento aritmético. 
Dentro de uma perspectiva de educação matemática crítica, é fundamental que o professor procure exercer uma função de promotor de discussões, levando em consideração o conhecimento que os estudantes trazem em sua bagagem de experiências na vida, valorizando os seus resultados e conclusões.

Consequentemente, nos aproximamos do que defendem Skovsmose (2001) e Kistemann Junior (2011), pois os estudantes desenvolveram o senso crítico e reflexivo perante o contexto social em que estão inseridos, a partir do que lhes foi proposto, produzindo significados para a tomada de decisões em suas ações de consumo.

\section{REFERÊNCIAS}

[1] Brasil. Base Curricular Nacional Comum do Ensino Médio. Ministério da Educação: Brasília, 2016.

[2] Costa, Luciano Pecorato. Matemática Financeira e Tecnologia: espaços para o desenvolvimento da capacidade crítica dos educandos da educação de jovens e adultos. Dissertação de Mestrado. Programa de Pósgraduação Profissional em Educação Matemática. Universidade Federal de Juiz de Fora, Juiz de Fora, 2012.

[3] Confederação Nacional do Comércio de Bens, Serviços e Turismo. Endividamento e inadimplência recuam em novembro. Disponível em: http://www.cnc.org.br/noticias/economia/endividamento-e-inadimplencia-recuam-emnovembro. Acesso em 02 de dezembro de 2018.

[4] Hoffman, Ruth Margareth. MORO, Maria Lucia Faria. Educação Matemática, contexto e educação financeira. XIII Conferência Interamericana de Educação Matemática: Recife, 2011.

[5] Kistemann Junior, Marco Aurélio. Sobre a produção de significados e a tomada de decisões de indivíduosconsumidores. Tese de Doutorado. Programa de Pós-graduação em Educação Matemática. Universidade Estadual Paulista, Rio Claro, 2011.

[6] Moran, José Manuel; Masetto, Marcos; Behrens, Marilda. Novas Tecnologias e mediação pedagógica. 10. ed. Campinas: Papirus, 2000.

[7] Organização para Cooperação do Desenvolvimento Econômico (OCDE). Trabalhando com o Brasil: Políticas melhores para uma vida melhor. Disponível em: http://www.oecd.org/latin-america/Active-with-Brazil-Port.pdf. Acesso em 28 novembro de 2018.

[8] Pais, Luiz Carlos. Educação escolar e as tecnologias da informática. Belo Horizonte: Autêntica, 2010.

[9] Palfrey, John; Gasser, Urs. Nascidos na era digital: entendendo a primeira geração de nativos digitais. Porto Alegre: Grupo A, 2011.

[10] Santos, Marcelo Antônio. Novas tecnologias no ensino de matemática: possibilidades e desafios. Revista Modelos. Osório. vol. 1, n.ำ 1.2011.

[11] Skovsmose, Ole. Educação Matemática Crítica: a questão da democracia. Campinas: Papirus, 2001. 


\section{Capitulo 16}

Software Geogebra e resoluções de problemas: Análise de uma experiência de ensino e aprendizagem

\section{Gabriel Araújo Freitas \\ Roberto Barcelos Souza}

Resumo: Nesta pesquisa apresentaremos a análise de uma experiência sobre o ensino e aprendizagem do conceito de função exponencial utilizando o software GeoGebra por meio de resolução de problemas. Justifica-se pela necessidade de se utilizar os aportes tecnológicos que hoje temos ao alcance, para provocar um ensino com qualidade e de maneira que seja interativa e dinâmica. Desta forma, objetivamos realizar uma reflexãocrítica sobre o uso de resolução de problemas aliando às tecnologias em sala de aula, em especial para o ensino de função exponencial, a partir de uma experiência desenvolvida durante a realização do Estágio Supervisionado Obrigatório do curso de Licenciatura em Matemática da Universidade Estadual de Goiás - Câmpus Quirinópolis e realizada com alunos do Ensino Médio de uma escola pública. Consideramos que o professor deve se comprometer em despertar no aluno a curiosidade e o espírito de investigação e não somente transmitir conhecimentos, buscando assim uma aprendizagem significativa.

Palavras-chave: Geogebra; Função Exponencial; Resolução de Problemas; Tecnologia. 


\section{INTRODUÇÃO}

Este trabalho é fruto de uma atividade proposta durante o desenvolvimento do Estágio Supervisionado Obrigatório, por um dos autores, do curso de Licenciatura em Matemática da Universidade Estadual de Goiás - Câmpus Quirinópolis. A proposta consiste em discorrer sobre o uso de resolução de problemas aliada ao software Geogebra aplicado ao ensino e aprendizagem do conceito de função exponencial. As motivações para essa proposta emergem da necessidade do professor de matemática inovar constantemente, procurando metodologias para tornar sua aula mais dinâmica e interativa, dialogando com o perfil dos alunos.

A superação dessas dificuldades de aprendizado de Matemática dos educandos perpassa refletir e assumir o que as pesquisas têm indicado: que o ensino escolar está em crise (LESSARD \& TARDIF, 2008). Não temos objetivo nesse trabalho de debater elementos que envolvem essa crise, tendo em vista que ela é ampla e envolve vários contextos de interpretação e causas. Todavia queremos ressaltar um elemento que fortalece a mesma, que corresponde à resistência das comunidades escolares e professores pelo avanço das Tecnologias de Informação e Comunicação no ensino, em nosso caso, o de Matemática. Paiva destaca que esse processo é constituído dos seguintes momentos: rejeição, adesão e normalização.

Quando surge uma nova tecnologia, a primeira atitude é de desconfiança e de rejeição. Aos poucos, a tecnologia começa a fazer parte das atividades sociais da linguagem e a escola acaba por incorporá-la em suas práticas pedagógicas. Após a inserção, vem o estágio da normalização, definido por Chambers e Bax (2006, p.465) como um estado em que a tecnologia se integra de tal forma as praticas pedagógicas que deixa de ser vista como cura milagrosa ou como algo a ser temido. (PAIVA, 2008. p.1).

Diante deste contexto, o presente artigo tem por finalidade socializar resultados de uma pesquisa que teve como objetivo realizar uma reflexão-crítica sobre o uso de resolução de problemas aliando à importância das tecnologias em sala de aula, em especial para o ensino de função exponencial com o software Geogebra.

Para tanto, aplicamos uma proposta de ensino e aprendizagem de função exponencial em um colégio Estadual para discentes do $1^{\mathrm{o}}$ ano do Ensino Médio. Vislumbramos como resultado, sinalizar que utilizando as ferramentas tecnológicas disponíveis, no caso o computador e o software GeoGebra, podemos aperfeiçoar o conhecimento dos educandos frente às representações de um determinado conceito matemático, em nosso caso, função exponencial.

Em trabalhos recentes de educadores, Borba e Penteado (2005), a informática vem sendo tratada como uma possível solução para alguns problemas educacionais como a falta de interesse do estudante e o baixo aprendizado em Matemática. Acreditamos que o professor deve se comprometer em tornar a sua aula mais atrativa, buscando sempre despertar nos discentes a curiosidade e os questionamentos, vale ressaltar que não podemos ficar somente a transmitir o conhecimento, visto que, este já está aí em livros, páginas da web, revistas e etc.

Portanto buscamos com esse trabalho uma metodologia diferente da convencional, aplicadas nas escolas públicas de Quirinópolis (GO), para que as aulas de matemática não centrem somente no quadro, livro didático e no giz. A metodologia de ensino foi construída pautada na Resolução de Problemas e o uso de Tecnologias.

Com isso, o objetivo principal do nosso artigo é fazer uma avaliação crítica de uma experiência do uso do software Geogebra no ensino do conceito de função exponencial. Assim, nossa questão de investigação envolve: quais serão os impactos no ensino e na aprendizagem de função exponencial tendo como recurso o software Geogebra, mediado pela resolução de problemas? Para tanto a prática visou despertar o interesse e a maior participação dos alunos, levando-os à construção do saber através das suas próprias percepções contextualizadas pela tecnologia, sendo o professor o mediador deste processo (FREIRE, 1996, p. 21).

\section{RESOLUÇÃO DE PROBLEMAS ALIADA ÀS TECNOLOGIAS NO ENSINO DE MATEMÁTICA}

Um dos primeiros pesquisadores a tratar sobre o tema "Resolução de problemas", foi George Pólya, que retratou em sua obra "How to solve it" (1995), na qual estudou os diversos métodos de resolução de problemas. 
Os presentes autores destacam a importância de se apropriar de conceitos matemáticos, visto que, surgiram devido a uma necessidade humana para facilitar a vida do homem. 0 conceito de função exponencial, tema do nosso trabalho, não foi diferente, esse conceito é muito aplicado em biologia, química e em matemática, como por exemplo: matemática financeira, crescimento da taxa de juros e o crescimento de uma população de bactérias, entre outros.

Segundo BASSANEZI,

O objetivo fundamental do "uso" da Matemática é de fato extrair a parte essencial da situação-problema e formalizá-la em um contexto abstrato onde o pensamento possa ser absorvido com uma extraordinária economia de linguagem. Desta forma, a Matemática pode ser vista como um instrumento intelectual capaz de sintetizar ideias concebidas em situações empíricas que estão quase sempre camufladas num emaranhado de variáveis de menor importância. (BASSANEZI, 2002, p. 18).

Observamos por Bassanezi (2002) a importância de como a Matemática é vista ou concebida pelo educando e a prática do professor interfere nessa concepção. Entendemos assim, que envolver os diferentes fenômenos naturais, culturais e sociais, tais como: o crescimento populacional, a meia-vida de uma substância, a medida da pressão atmosférica, os resfriamentos de um corpo, dentre outros, ao ensino de Matemática.

Esse fato torna ainda mais relevante o estudo dessas funções no Ensino Médio e ressalta seu papel na interdisciplinaridade da Matemática com outras disciplinas. É uma oportunidade para se convencer que o ensino e a aprendizagem podem ganhar mais e melhor sentido com esse estudo, pois cria a oportunidade na qual o aluno percebe a importância do conteúdo a ser trabalhado, o que faz da contextualização uma importante ferramenta de ensino para resolver problemas reais.

Nos últimos tempos tem ocorrido grandes manifestações sobre o ensino-aprendizagem da Matemática, visto que, ela é vista com o "bicho de sete cabeças". Contudo, com as mudanças que vêm acontecendo sobre o ensino através de novas metodologias, uma se destaca e demonstra ter grande potencial, que é o ensino através de Tecnologias, elas vão desde uma aula com um retroprojetor até as mais empolgantes, segundo os presentes autores, que são através de softwares, nas quais o aluno passa a ser o sujeito transformador e o professor apenas o mediador do conhecimento.

Com isso é importante colocar os alunos em um contexto social, visto que a tecnologia está em toda parte e ela poderá ser uma poderosa ferramenta para apropriação de conceitos matemáticos.

Pesquisadores como Borba (1999), destacam que o ensino através de softwares pode dinamizar o baixo apropriamento de discentes no ensino aprendizado da Matemática, com tudo podendo inovar conteúdos em que a grande parte das vezes são ensinados no modo tradicional, o professor explica e em seguida passa diversas atividades parecidas para o aluno. 0 problema está aí, já que o aluno só consegue resolver situações problemas já vistas anteriormente, fazendo assim uma aprendizagem mecânica dos conceitos Matemáticos ensinados.

Diante disso, observamos com bons olhos o uso das diversas tecnologias no ensino e aprendizagem de conceitos matemáticos, em especial, o uso do software Geogebra. Ele é um software gratuito e de fácil manuseio e pode ser usado como uma importante ferramenta para o ensino de conceitos matemáticos. Foi criado pelo prof. Dr. Markus Hohenwarter, em 2001 e tem chamado bastante atenção por reunir geometria, álgebra e cálculo. Podendo assim ser aplicado em diversos conceitos Matemáticos.

O software pode ser usado de forma dinâmica para construir segmentos, pontos, retas, tabelas e gráficos. Entre suas funções didáticas mais importantes estão a apresentação algébrica e geométrica de um determinado objeto, por essas e outras atribuições o Geogebra é uma importante ferramenta para se ensinar função, visto que mostra com praticidade o resultado na tela do computador.

Não é de hoje que a Educação vem se moldando, foi assim quando surgiu a calculadora, o retroprojetor e o vídeo. Contudo com passar dos anos eles vêm perdendo o espaço devido ao mundo tecnológico que alunos têm computadores nas palmas de suas mãos. O profissional da Educação deve se apropriar dessa ferramenta e passar a usá-la em sua metodologia, visto que ela tem grande potencial de diminuir a falta de atenção dos discentes e aumentar a aprendizagem dos mesmos. 
Romero traz concepções a respeito do ensino sem o uso dos softwares que é,

A tecnologia, especificamente os softwares educacionais disponibiliza oportunidade de motivação e apropriação do conteúdo estudado em sala de aula, uma vez que em muitas escolas de rede pública e particular, professores utilizam recursos didáticos como lousa e giz para ministrarem suas aulas, este é um dos diversos problemas que causam o crescimento da qualidade não satisfatória de ensino, principalmente na rede estadual. (ROMERO, 2006, 1).

No ensino atual é muito utilizada a aprendizagem mecânica, o problema está que essa aprendizagem favorece o ensino de modelos pré-definidos, isto causa um déficit na aprendizagem do aluno, pois o mesmo só consegue resolver algo que já foi proposto anteriormente.

A nossa proposta foi utilizar o software como ferramenta no ensino do conceito de função exponencial e nos fundamentamos na teoria da aprendizagem significativa de Ausubel (2003) num ambiente informatizado.

Essa aprendizagem favorece um ensino sistematizado no qual o aluno tem autonomia, visto que ele absorve o conceito ensinado e consegue usá-lo em diversas situações problemas, onde muitas vezes são novas para ele.

\section{METODOLOGIA}

O presente artigo buscou analisar as vantagens na abordagem da resolução de problemas através do software Geogebra. A pesquisa foi desenvolvida no segundo semestre de 2018 e envolveu cerca de 30 alunos do 1 ano do Ensino Médio de uma escola pública da cidade de Quirinópolis (GO). A turma foi submetida ao manejo do software Geogebra. Os estudantes usaram o software para resolução de problemas buscando a aprendizagem significativa do tema proposto.

Foram seguidas as seguintes etapas:

1o etapa: Como o software pode ser algo novo para os alunos, já que muitos podem não ter o domínio dele, a primeira etapa foi a apresentação do software, ou seja, passamos para eles o que o software pode oferecê-los, qual a nossa intenção com aquela metodologia.

2o etapa: Nessa etapa buscou desenvolver problemáticas que obriguem os alunos a pensar, para não ficarmos naquela ideia ultrapassada de reprodução do conhecimento, deixar eles mesmos terem suas conclusões sobre o conceito ensinado, podendo existir intervenção para orientação. Os problemas envolvidos ao conceito de função exponencial.

3 etapa: Os alunos foram submetidos a uma avaliação que foi constituída através de questionários que abordaram sobre a experiência que tiveram, se acharam importante e se gostariam que as aulas de Matemática fossem abordadas dessa maneira, através do recurso da tecnologia e por último ver se o apropriamento do conceito foi satisfatório.

A coleta de dados da investigação foi desenvolvida por meio de questionários, aplicados no laboratório life 17 e foi dividido em dois blocos: 0 primeiro foi relativo à Aprendizagem significativa dos conceitos apresentados e o segundo frente à avaliação realizada pelos alunos.

Utilizamos o questionário como instrumento de coleta de dados, pois segundo (MARCONI \& LAKATOS, 2004) trazem algumas vantagens, como por exemplo: economiza tempo; atinge maior número de pessoas simultaneamente; obtém respostas mais rápidas e mais precisas; há maior liberdade nas respostas, em razão do anonimato; há menos risco de distorção, pela não influência do pesquisador e etc.

\section{RESULTADOS E DISCUSSÕES}

Foi possível observar durante a aplicação das atividades que os educandos ficaram impressionados com o software, por ser uma ferramenta tecnológica, despertou o interesse dos alunos pela atividade proposta, muitos não conheciam o Geogebra, e depois que passaram a conhecer ficaram surpresos com a praticidade em aprender conceitos matemáticos utilizando o aplicativo.

\footnotetext{
17 Laboratório interdisciplinar de formação de educadores.
} 
Foi possível notar durante a aplicação que os educandos gostaram do software, pois muitos pediram para tirar fotos dos gráficos prontos. Com isso foi plausível observar que, por ser uma ferramenta tecnológica, despertou o interesse, mostrado através de falas dos alunos, como: "Ele serve para outros conteúdos? " e "Como que faz para baixar?".

Os alunos aprenderam manuseá-lo, construíram gráficos de função exponencial e ao verem os gráficos prontos alguns alunos disseram: "Que prático", "Que legal esse aplicativo" e "Vou baixar para fazer em casa", foi possível perceber que através das falas dos alunos a aula foi interessante.

Assim os presentes autores enfatizam que a tecnologia pode sim ser um potente aliado ao ensino e aprendizagem de conceitos matemáticos, buscando assim elucidar no aluno uma aprendizagem significativa, visto que, ela pode despertar nos mesmos um caráter investigativo, onde o aluno se torna o sujeito e construtor do seu conhecimento e o professor o mediador.

Uma das atividades aplicadas os alunos tiveram que utilizar do método de resolução de problemas, em que eles teriam que fazer dobraduras em um papel e representar a função correspondente com a quantidade de dobraduras. Foi possível constatar que todos conseguiram identificar facilmente, vale ressaltar que tiveram ainda dificuldade em relação a quando o expoente é zero, visto que o papel inicialmente é um retângulo onde a função seria $f(x)=2^{0}$. Após essa resposta foi questionado se eles conseguiriam construir o gráfico no Geogebra representando a variação das quantidades de acordo com a quantidade de dobraduras e foi constatado que os mesmos conseguiram identificar com mais facilidade.

Figura 1: (Potenciação com dobraduras de papel.)

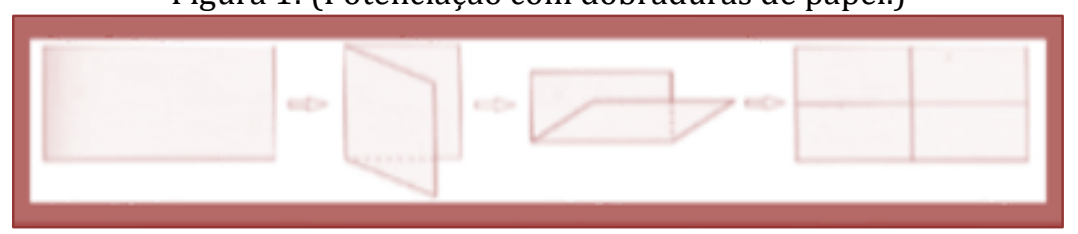

Fonte: DANTE, 2011.

Chamamos a atenção aqui para a visualização que os educandos tiveram frente aos gráficos. Consideramos que a visualização, o novo olhar frente aos gráficos pelos educandos foi um dado relevante em nosso estudo. Segundo Borba (1999) essa visualização está ligada às capacidades de interpretar e manusear as figuras, representadas pelo gráfico.

Essa visualização foi mediada pelo diálogo de Freire (1996), já sinalizava a importância do professor discutir achados e não apenas apresentar algo pronto. E, que alunos pudessem ter oportunidade de experimentar, debater dúvidas, interrogar, no processo de ensino e aprendizagem.

Posteriormente foi pedido para que produzissem gráficos em que a base variasse como: " $f(x)=$ $2^{x} ; g(x)=3^{x} ; h(x)=4^{x} ; p(x)=5^{x}$ e $q(x)=1000^{x "} \quad$ e $\quad r(x)=\left(\frac{1}{2}\right)^{x} ; s(x)=\left(\frac{1}{3}\right)^{x} ; t(x)=\left(\frac{1}{4}\right)^{x} ; u(x)=$ $\left(\frac{1}{5}\right)^{x}$ e $v(x)=\left(\frac{1}{1000}\right)^{x}$ ", foram obtidas as seguintes respostas: "Quanto maior a base mais próxima a curva ficará do eixo das ordenadas, porém será uma função crescente"; "Quando a função tiver a base mais próxima de um, ela ficará mais longe do eixo das ordenadas" ; "Quanto mais próximo de 0 for a base, mais próxima a curva será do eixo das ordenadas, porém será uma função decrescente”. 
Figura 2 e 3: (Comportamento gráfico sob a variação da base a)

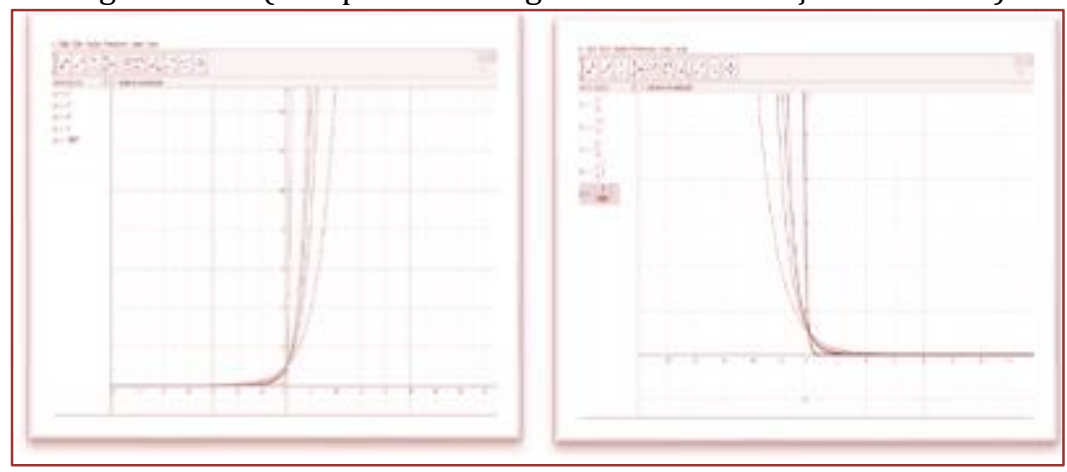

Fonte: Autor.

Após o término das atividades foi aplicado novamente outro bloco do questionário que visou a avaliação realizada pelos alunos, no qual foram feitos os seguintes questionamentos:

Se conhecendo o software o aluno utilizaria o mesmo para estudar para provas, e as respostas foram: "Sim e o desenvolvimento é muito melhor"; "Sim, ele é eficiente e rápido". Em seguida foi perguntado se apesar do pouco espaço de tempo, eles acharam a aula proveitosa e tivemos as seguintes respostas que foram: "Sim muito"; "Sim, pois foi um jeito divertido de aprender"; "Sim, mas queria ter mais tempo"; "Sim, porque aprendemos a fazer vários gráficos"; "Sim, muito produtiva e melhor que as aulas normais" e "Sem dúvidas".

O aluno ao usar o computador para estabelecer o seu conhecimento, passa a ser uma máquina para ser ensinar, propiciando assim condições para que o mesmo possa delinear a resolução de problemas, levando-o assim a refletir sobre os resultados que obteve e esquematizando assim novas estratégias para a construção do seu conhecimento.

Portanto foi possível perceber através do questionário que foi alcançado o objetivo da atividade, os alunos compreenderam o conceito de função exponencial, conseguiram manusear o software, ficaram mais interessados com a aula, aprovaram o uso do software para estudar, e gostariam de ter mais aulas usando o Geogebra. Isso mostrou que o recurso tecnológico pode ajudar o professor de Matemática a despertar o interesse de seu aluno para aprender determinados conceitos como foi o caso da função exponencial, e que tirar o aluno da sua rotina e usar um método diferente para ensinar pode ser muito proveitoso para a apropriação de conhecimento dos educandos. "A educação é e sempre foi um processo complexo que utiliza a medida de algum tipo de meio de comunicação como complemento ou apoio à ação do professor em sua interação pessoal e direta com os estudantes" (BELLONI, 1999. p.54). Corroborando com Belloni, acreditamos que a tecnologia pode sim ser uma poderosa ferramenta para o ensino-aprendizagem de conceitos Matemáticos.

\section{CONSIDERAÇÕES FINAIS}

Assim acreditamos que a nossa pesquisa contribuirá para que futuros educandos possam utilizar nas suas aulas de Matemática métodos alternativos para a resolução de problemas, aliando assim o ensino e aprendizagem aos recursos tecnológicos. Com isso as aulas de Matemática poderão se tornar mais atrativas, visto que muitos discentes já nasceram com essa tecnologia e talvez por isto sejam tão receptivos a ela.

0 professor que utiliza essa ferramenta tem grandes chances de diminuir o déficit de aprendizagem, visto que os discentes se sentem mais motivados a aprenderem por estar em contato com essa tecnologia no seu dia-a-dia em smarthphones, tablets, computadores etc. Vale ressaltar que o método de resolução de problemas com o recurso da tecnologia é uma via de mão dupla no diálogo entre os alunos e o professor com vistas para uma aprendizagem mais significativa. 


\section{REFERÊNCIAS}

[1] Ausubel, D. P. Aquisição e Retenção de Conhecimentos: Uma Perspectiva Cognitiva. Lisboa: Plátano, 2003.

[2] Bassanezi, R.C. Ensino-aprendizagem com modelagem matemática: uma nova estratégia. São Paulo: Contexto, 2002

[3] Belloni, Maria Luisa. Educação à distância. Campinas: Editores Associados, 1999.

[4] Borba, Marcelo C. Tecnologias informáticas na Educação Matemática e reorganização do pensamento. Pesquisa em educação matemática: concepções e perspectivas. São Paulo: UNESP, p. 285-295, 1999.

[5] Chambers, A; Bax, S. Making Call work: Towards normalisation. System. v. 34, p. 465-479, 2006.

[6] De Carvalho Borba, Marcelo; Penteado, Miriam Godoy. Informática e Educação Matemática”, Autêntica, Belo Horizonte, MG, 2005.

[7] Freire, Paulo. Pedagogia da autonomia: saberes necessários à prática docente. São Paulo: Paz e Terra, p. 25, 1996.

[8] Freire, Paulo. Pedagogia da autonomia: saberes necessários à prática educativa. São Paulo: Paz e Terra, 1996. Coleção leitura, p. 21, 2005.

[9] Lessard, Claude; Tardif, Maurice. As transformações atuais do ensino: três cenários possíveis na evolução da profissão de professor. 0 ofício do professor: história, perspectivas e desafios internacionais. Petrópolis: Vozes, p. 255278, 2008.

[10] Marconi, M. de A.; Lakatos, Eva Maria. Metodologia científica. São Paulo: Atlas, 2004.

[11] Paiva, Vera Lúcia Menezes de Oliveira. O Uso da Tecnologia no Ensino de Línguas Estrangeira: breve retrospectiva histórica.

[12] Polya, G. A Arte de resolver problemas. Rio de Janeiro: Ed. Interciência,1995. 


\section{Capítulo 17}

\section{O logo no processo de aprendizagem em Matemática}

\section{Gabriel Geraldino Cardoso}

\section{Elisangela Pavanelo}

Resumo: Neste minicurso apresentamos a importância das tecnologias digitais no processo de aprendizagem em matemática. Para isso, trabalhamos com o Software Logo, por ser um software de livre acesso, apresentar uma linguagem simples e atrativa aos alunos. A ideia principal foi a de explorar conceitos que estimule o pensamento abstrato pela analogia entre álgebra, geometria e movimento, como por exemplo, o conceito de mínimo múltiplo comum e máximo divisor comum. Com isso buscamos apresentar as potencialidades de um trabalho que envolve este software e a sala de aula.

Palavras-chave: Logo; Analogia Geométrica; Tecnologias Digitais, Educação Matemática. 


\section{INTRODUÇÃO}

O software Logo foi concebido no fim dos anos 60, por Seymour Papert, um educador matemático, no MIT - Massachusetts Institute of Technology, de Cambridge, MA, Estados Unidos, e adaptada para o português em 1982, na Unicamp, pelo Núcleo de Informática Aplicada à Educação (NIED).

Figura 1 - Seymour Papert e uma tartaruga de chão

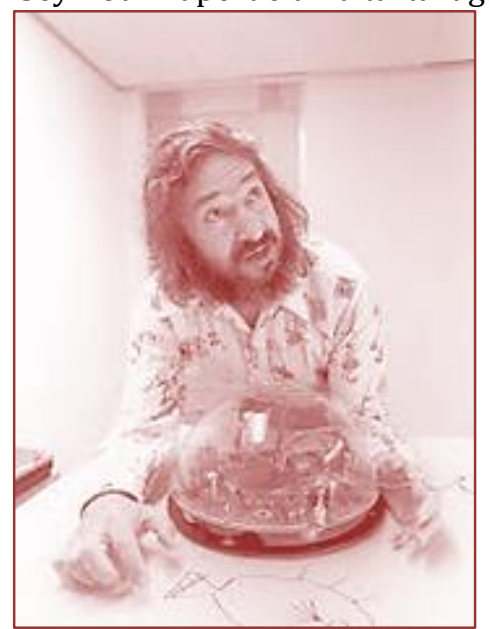

Fonte: https://lume.ufrgs.br/bitstream/handle/10183/37116/000819648.pdf?...1 18

Para Papert (1985), o papel central da Tartaruga não deveria ser visto, inocentemente, como uma resposta para todos os problemas educacionais. Mas sim como um instrumento educacional válido, com a principal função de servir como modelo para outros objetos, ainda a serem inventados.

Meu interesse está no processo de invenção desses "objetos-de-pensar-com", objetos em que há uma interseção de presença cultural, conhecimento implícito, e a possibilidade de identificação pessoal (Papert, p. 26, 1985).

Logo é uma linguagem de programação, um meio de comunicação entre o computador e a pessoa que irá utilizá-lo. A principal diferença entre o Logo e outras linguagens de programação está no fato de que foi desenvolvida para ser usada por crianças. Tal linguagem tem suporte teórico nos estudos piagetianos, principalmente referente à reflexão do aluno, sendo melhor aproveitado se o professor tiver um bom conhecimento sobre seu método clínico. ${ }^{19}$

É, então, uma linguagem simples e poderosa. Simples, porque é de fácil aprendizagem, e poderosa, pois possui recursos sofisticados, que atendem às exigências de programadores experientes.

Apesar de ser uma linguagem acessível às crianças, o LOGO não é uma linguagem infantil, pois por meio dela, torna-se possível trabalhar até mesmo Robótica com crianças.

O LOGO é uma linguagem de programação interpretada, em que cada linha é lida pelo interpretador que a executa. Esse processo é de execução lenta, mas tem a vantagem de não exigir a compilação completa para cada mudança feita em seu código. Entende-se que isso é o ideal em ambiente de aprendizagem.

Essa linguagem também oferece algo que não encontramos em outras linguagens: a tartaruga gráfica, desenhar linhas na tela, permitindo fazer o que as linguagens tradicionais não conseguem, dar um retorno imediato (feedback), o que torna essa linguagem divertida e mais fácil de aprender.

\footnotetext{
${ }^{18}$ Retirado de: https://lume.ufrgs.br/bitstream/handle/10183/37116/000819648.pdf?...1. Inicialmente, a linguagem LOGO era utilizada por um robô em formato de semiesfera, que andava e girava, deixando um traço de caneta sobre o papel por onde se movimentava (Matte, 2011).

190 método piagetiano é clínico no sentido de ir além do óbvio, da resposta estereotipada, buscando compreender o ponto de vista da análise do sujeito. As características gerais das explicações, a maneira como o indivíduo resolve os problemas apresentados, como chega às suas explicações, buscando também perceber se guarda coerência, se manifesta contradições, e também, de forma mais peculiar, o que há de criatividade nas respostas, mas, ainda assim, sem afastar-se do sujeito epistêmico.
} 
De acordo com Valente (1995),

quando o aluno interage com o computador através do Logo, ele programa o computador ou "ensina" a Tartaruga como produzir um gráfico na tela. Isso implica na descrição da solução do problema através dos comandos do LOGO (procedimentos Logo). O computador, por sua vez, executa esses procedimentos e a Tartaruga apresenta na tela um resultado na forma de um gráfico. 0 aluno olha para a figura que está sendo construída na tela e para o desenho final e faz uma reflexão sobre essas informações.

Essa reflexão pode leva-lo a depurar o procedimento realizado inicialmente, quando o resultado é diferente da sua intenção original.

Para Valente (1995) o modelo da descrição-reflexão-depuração permite entender que a grande contribuição do computador é o fato de o aluno poder executar suas ideias numa máquina que fornece um resultado fiel e preciso sobre o que o aluno realizou. 0 que o computador fornece não é provido de nenhum outro componente intelectual ou emocional que podem intervir no resultado. Se algo não saiu como era esperado, esse resultado é fruto somente do que o aluno forneceu. 0 que pode contribuir para mostrar o seu entendimento, ou não, sobre o assunto estudado.

Ponte e Canavarro (1997) afirmam que este é um excelente ambiente de aprendizagem matemática, pois a geometria desenvolvida no software constitui um ambiente estimulante que incentiva os alunos a desenvolver procedimentos para ensinar a tartaruga na construção de figuras simples ou complexas, podendo ser um utilizado como apoio a conteúdos que exigem uma grande abstração, como é o caso de vários conceitos algébricos.

Enquanto processos matemáticos, tanto a álgebra, como a aritmética precisam ser desenvolvidos a partir do desencadeamento dos processos de abstração e generalização, e necessitam de uma representação e de uma lógica matemática que possibilite sua elaboração. De acordo com Lins e Gimenez (1997), entende-se que a álgebra, a aritmética e a geometria constituem os alicerces da matemática escolar relativamente ao ensino fundamental. Ensinar álgebra é possibilitar a formação do pensamento algébrico do indivíduo; como professores, concordamos com essa premissa.

No entanto, muitas vezes percebemos que os alunos têm a capacidade de aprender certo conteúdo matemático, mas se tornam, muitas vezes, incapazes pela dificuldade de abstração (visualização) que acompanham suas tentativas. (Fonseca, 1998)

Sentimos, então, a necessidade de propor atividades a partir de tecnologias digitais, nesse caso o software $\operatorname{Slogo}^{20}$, com o objetivo de proporcionar uma melhor visualização para fundamentação de desenvolvimentos conceituais, permitindo assim que se identifique e entenda os motivos que levam ao conhecimento algébrico.

Ao utilizar conceitos familiares ao estudante sobre, por exemplo, o movimento para frente, para trás, para esquerda e para direita da tartaruga, podemos aumentar o interesse do estudante sobre conceitos formais de matemática por meio de atividades computacionais lúdicas.

\section{OBJETIVOS DO TRABALHO}

A fim de apresentar nossa proposta de pesquisa, ministramos um minicurso durante o Xiii Encontro Nacional De Educação Matemática e outro durante a Semana da Ciência e Tecnologia 2019 organizado pela Universidade Estadual Paulista (UNESP) - Campus de Guaratinguetá. Contando com a presença desde graduandos, mestrandos e doutorandos até professores da Educação Básica

O minicurso teve como objetivo principal mostrar as contribuições que o software Logo pode proporcionar aos processos de ensino e de aprendizagem da matemática para alunos e professores do Ensino Básico. Para tal, alguns objetivos específicos foram traçados:

- Apresentar o software e seus principais comandos básicos;

- Compreender conceitos algébricos através de sua analogia geométrica;

\footnotetext{
${ }^{20}$ Slogo é a versão mais atual do software Logo
} 
- Discutir de quais formas o software pode contribuir para a aprendizagem do aluno. De maneira que oportunize desenvolver atividades com o software Slogo que:

a) estimule o pensamento abstrato pela analogia entre álgebra, geometria e movimento.

b) favoreça o raciocínio lógico pela decomposição de atividades complexas em um conjunto de atividades elementares.

c) instigue o estudante a propor soluções alternativas a problemas matemáticos, aumentando sua confiança sobre o uso formal da matemática na resolução de problemas diversos.

\section{ESTRUTURA DO MINICURSO}

Inicialmente foi realizada uma apresentação com o objetivo de conhecer o grupo. Para tanto, procuramos dialogar sobre os motivos que os levaram a se inscreverem no minicurso, suas expectativas em relação à proposta de trabalho e se utilizam algum recurso tecnológico em suas aulas.

Nessa discussão percebemos que 55\% dos professores conheciam o SLOGO, esse conhecimento vinha ou do curso de graduação, ou de cursos de formação continuada de professores. Mas nenhum deles o utilizava em sua prática docente. Dos $45 \%$ que não conheciam o software, viram nele, ao final do minicurso um potencial interessante para a prática docente.

Nossa sugestão foi de que os participantes se dividissem em grupos de três por computados. Cada participante recebeu um roteiro das atividades e das propostas a serem trabalhadas.

0 minicurso foi estruturado em três momentos.

10 Momento: apresentação dos principais comandos do software e de sua interface. Para isso, as primeiras atividades foram relacionadas à construção de polígonos básicos.

Figura 2 - Interface do Slogo

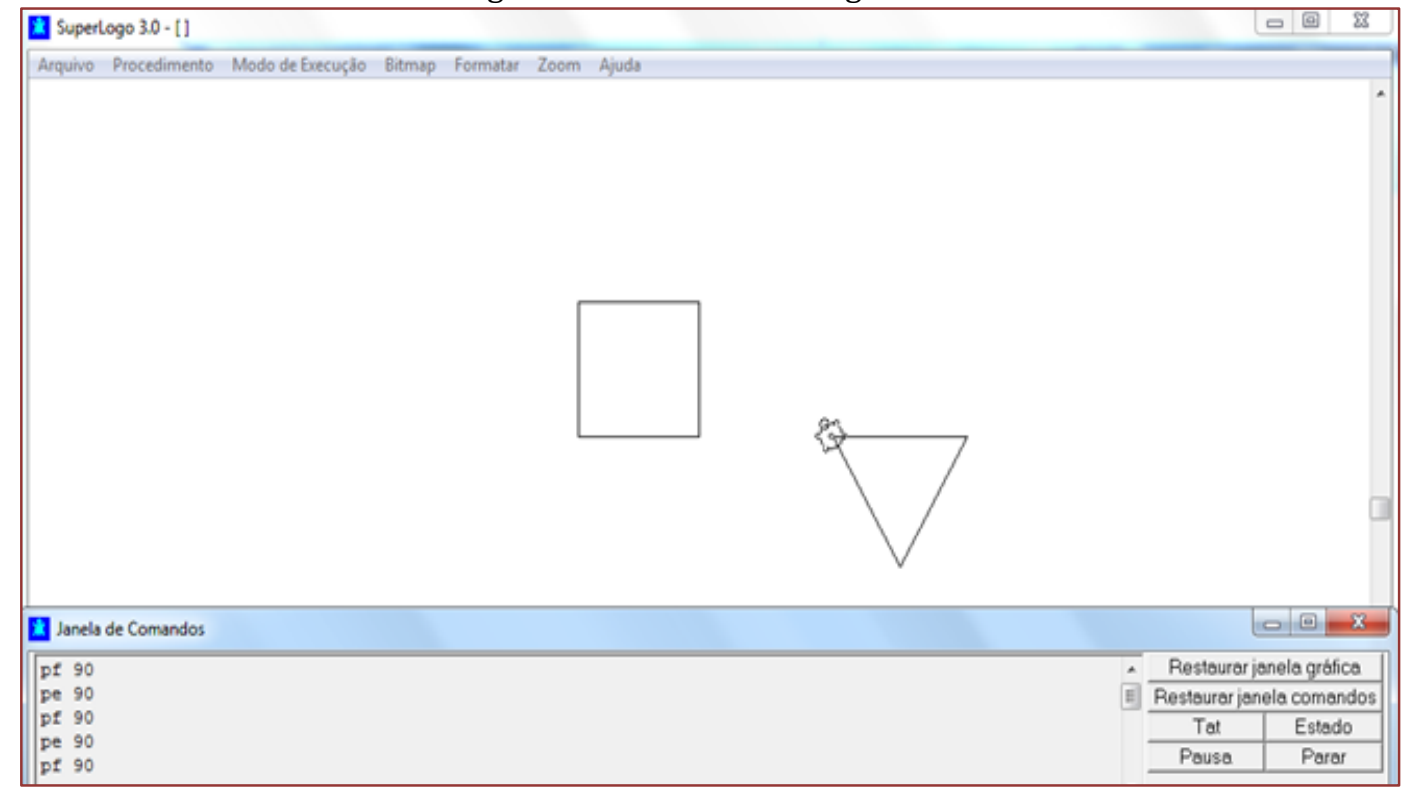

Fonte: Próprios autores

2o Momento: A partir dos mesmos polígonos construídos na atividade anterior, trabalhamos comandos mais elaborados do software Os participantes utilizaram o comando "repita" para construir o mesmo polígono da etapa anterior e outros mais elaborados. Foram trabalhados também algumas operações como: operação Elementos e Predicados.

3o Momento: Os participantes analisaram as atividades realizadas nos momentos anteriores e tentaram construir uma "fórmula geral" para elaboração de qualquer polígono de n lados no software. 
Por fim, com objetivo explorar o pensamento abstrato em matemática através de sua analogia com a geometria, trabalhamos o conceito de Mínimo Múltiplo Comum (M.M.C.) e de Máximo Divisor Comum (M. D. C.) e o cálculo por divisões sucessivas.

Para o cálculo do MMC, nos baseamos em um artigo da Revista do Professor de Matemática (RPM), n. 32 de Cardoso e Gonçalves, em que se utiliza a contagem como método.

Os passos no Slogo são:

1) Dados dois números $m$ e n que se queira achar o MMC, construa no SLOGO um retângulo com essas medidas, e subdivida esse retângulo em quadrados de medida 1 unidade. Temos que lembrar que a tartaruga do SLOGO anda em passos. Nesse exemplo utilizamos os valores 6 e 2, ou seja vamos encontrar o MMC entre 6 e dois. Aqui cada aluno irá construir o retângulo de uma maneira. Alguns utilizando mais comandos outros menos, se torna importante aqui discutir uma maneira mais simples de obtermos o mesmo resultado, explorando aqui o raciocínio da programação do software.

Figura 3 - Interface do Slogo

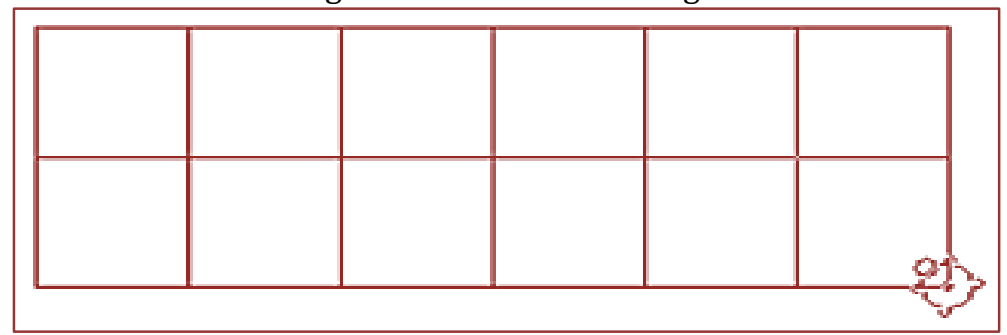

Fonte: Próprios autores

Atentamos para o fato da posição da tartaruga no final da construção do retângulo.

2) Partindo de um dos vértices do retângulo, traçamos as diagonais dos quadrados unitários observando a seguinte ordem:

a) traçamos a diagonal do quadrado que tem o vértice coincidente com o vértice escolhido do retângulo.

b) traçamos, a partir do vértice no qual paramos, as diagonais dos quadrados que têm um ângulo oposto pelo vértice com o quadrado anterior ou, na ausência desse quadrado, traçamos a diagonal do quadrado ao lado e a partir do vértice onde paramos.

c) As diagonais dos quadrados unitários devem ser traçadas até que se chegue a um dos outros vértices do retângulo $A B C D$.

d) Contamos quantos quadrados tiveram suas diagonais traçadas. $O$ número encontrado é o MMC de $m$ e $n^{21}$, no nosso exemplo, entre 6 e 2.

Figura 3 - Interface do Slogo

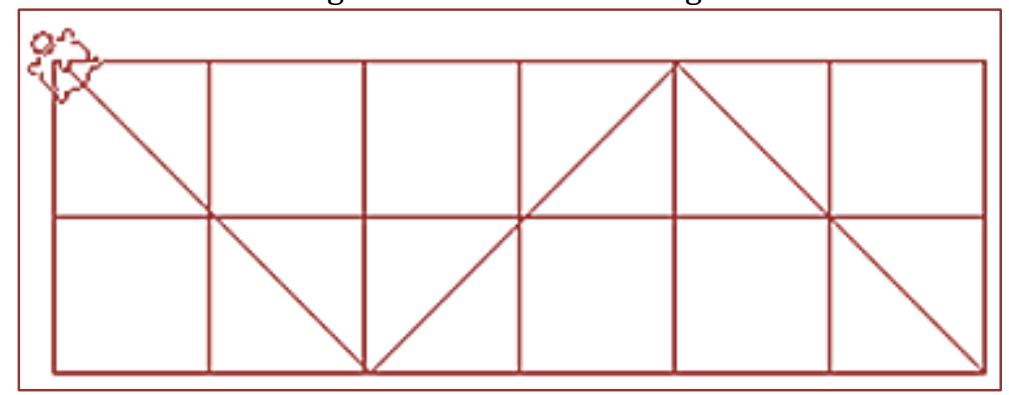

Fonte: Próprios autores

${ }^{21}$ Retirado do artigo “Uma interpretação Geométrica para o MMC” de Cardoso e Gonçalves n. 32. 
O interessante aqui é cada aluno explore os comandos do Slogo e perceba a programação que é necessária para que a tartaruga faça o que é pedido. Depois desse processo, fazer tentativas e discussões para que a tartaruga faça a tarefa de maneira cada vez mais simples, a partir da exploração de diferentes comandos do software.

De acordo com Cardoso e Gonçalves, ao se partir de um vértice do retângulo e chegar a um outro vértice desse mesmo retângulo, traça-se diagonais de um número de quadrados correspondentes a um múltiplo tanto de m quanto de $n$; parando no primeiro outro vértice do retângulo $A B C D$, estamos determinando o mínimo dentre os múltiplos comuns de m e n.

Com esta atividade, além de explorarmos o raciocínio da linguagem Slogo, trabalhamos a ideia geométrica desse importante conceito matemático.

Já para o cálculo do MDC, nos baseamos em um artigo da Revista do Professor de Matemática (RPM), n. 29 de Oliveira, em que utiliza divisões sucessivas como método.

O autor propõe o seguinte enunciado para encontrar o MDC entre dois números: Dados dois números naturais a e b, construímos um retângulo com essas dimensões. Cobrindo esse retângulo com os maiores quadrados possíveis, o lado do menor quadrado será o MDC entre a e b (Oliveira, RPM, n. 29).

Para ilustrar esse enunciado, sugerimos um trabalho no SLOGO, utilizando o mesmo exemplo do autor.

Encontrar o MDC de 55 e 15.

1) Construir um retângulo de dimensões 55 e 15. Aqui o aluno terá que pensar, como na linguagem SLOGO, conseguirá esse resultado, pois a tartaruga anda em passos.

Figura 3 - Interface do Slogo

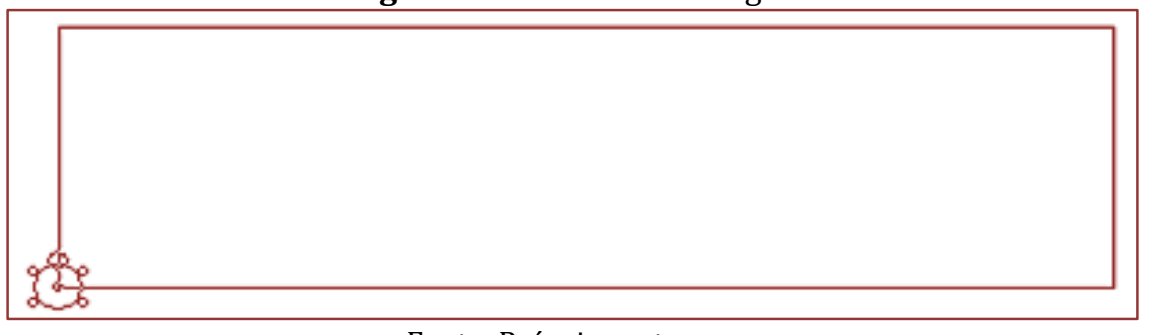

Fonte: Próprios autores

2) Cobrir esse retângulo com os maiores quadrados possíveis. Inicialmente são três quadrados de lado 15 e um quadrado de lado 10.

Figura 4 - Interface do Slogo

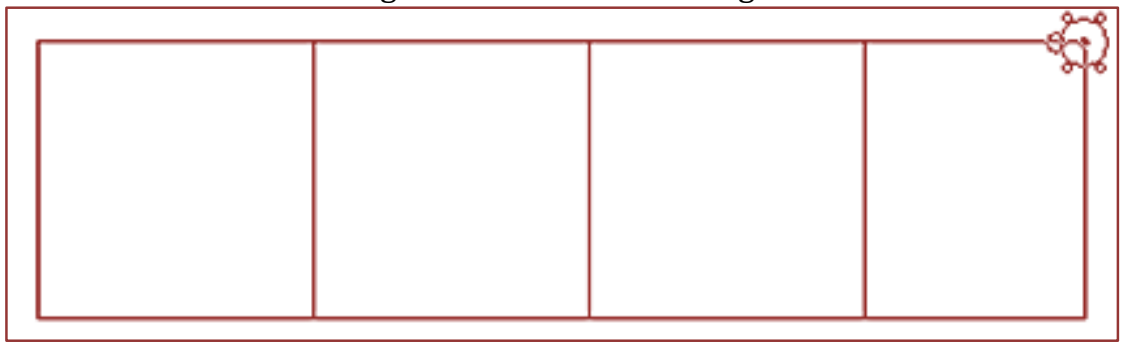

Fonte: Próprios autores

Em seguida, neste quadrado de lado 10, podemos construir dois quadrados de lado 5, que é último passo onde obtemos valores inteiros. Isto é o MDC entre 5 e 15 é 5. 
Figura 5 - Interface do Slogo

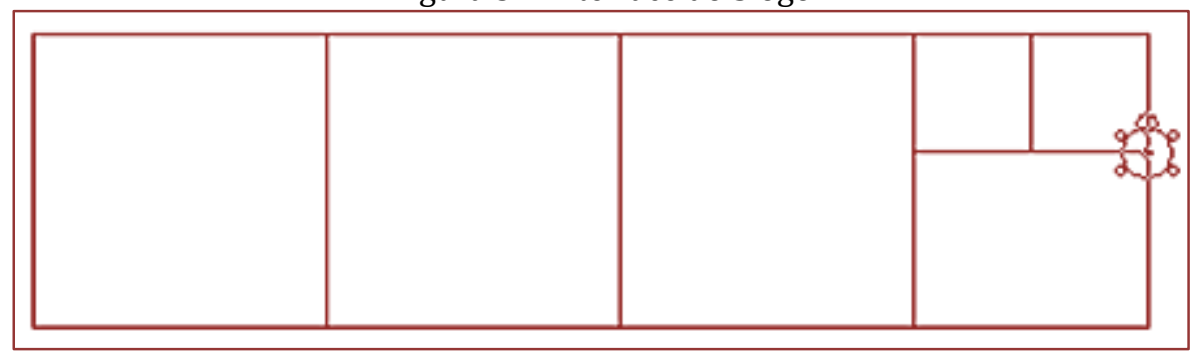

Fonte: Próprios autores

De acordo com Oliveira, este método consiste em encontrar uma forma de ilustrar um procedimento aritmético usando áreas, mostrando a importância do relacionamento de diferentes temas da matemática elementar. 0 autor aponta que o embasamento desse método se encontra no livro História da Matemática, de Carl Boyer, onde existe uma referência ao livro dos Elementos de Euclides, que contém, essencialmente, o "método" imaginado.

Explorando algumas discussões

Este trabalho foi apresentado em um minicurso durante o XIII Encontro Nacional De Educação Matemática, em 2019. Nesta oportunidade desenvolvemos estas atividades com os participantes compostos por professores de Matemática e alunos de graduação em Matemática.

Nesta oportunidade questionamos os participantes para que destacassem pontos que lhe chamaram a atenção no desenvolvimento das atividades propostas no minicurso. Alguns dos destaques foram:

1) a sintaxe dos comandos do SLOGO que proporcionam possibilidades de relação entre os comandos de outros softwares de ensino de matemática;

2) muitos dos participantes, mesmo entre os que conheciam o software, não tinham tido contato com atividades que proporcionassem uma discussão geométrica com tecnologia, sobre MMC e MDC entre dois números inteiros.

3) a interessante relação entre a álgebra, a geometria com um trabalho envolvendo tecnologia.

4) a autonomia dos alunos na programação do software, que pode ser desenvolvida de diferentes maneiras para se obter o resultado gráfico esperado.

5) a oportunidade que se proporciona do aluno pensar sobre os movimentos da tartaruga e a geometria.

\section{CONSIDERAÇÕES FINAIS}

0 trabalho com tecnologias digitais, nos processos de ensino e de aprendizagem em matemática, tem se mostrado eficiente, uma vez que permite aos professores e alunos explorar situações que dificilmente se conseguiria apenas por meio de mídias tradicionais. O SLOGO, por se tratar de uma linguagem simples, pode viabilizar significativamente o contato do aluno com o computador e despertar-lhes o prazer de explorar ambientes matemáticos. 0 diferencial deste trabalho está na iniciativa de trabalhar, com o SLOGO, a visualização geométrica de alguns conceitos algébricos.

No minicurso procuramos apresentar aos professores e graduandos a importância de um trabalho com tecnologias digitais e os familiarizar com o software que, mesmo a partir da compreensão de seus comandos básicos, pode auxilia-los na elaboração de importantes atividades envolvendo conceitos algébricos e geométricos que podem ser desenvolvidas em sala de aula.

Entendemos, a partir pontos destacados pelos participantes, que cumprimos nosso objetivo de mostrar as contribuições que o software Slogo pode proporcionar aos processos de ensino e de aprendizagem da matemática, estimulando o pensamento abstrato pela analogia entre álgebra, geometria e tecnologia, instigando os participantes a propor soluções alternativas a tradicionais problemas matemáticos. 


\section{REFERÊNCIAS}

[1] Babbie, E. The practice of social research. 4th ed. Belmont, Wadsworth Publ., 1986.

[2] Fonseca, V. Aprender a Aprender: a Educabilidade Cognitiva. Porto Alegre: Artes Médicas, 1998.

[3] Cardoso, M. L.; Gonçalves, O. A. Uma interpretação geométrica do MMC. Revista do Professor de Matemática (RPM), n. 32.

[4] Lins, R. C. e Gimenez, J.. Perspectivas em aritmética e álgebra para o século XXI. Campinas, SP. Papirus, 1997.

[5] Matte, M. L. A linguagem Logo como possibilidade de aprendizagem em Matemática, TCC, Porto Alegre UFRGS, 2011.

[6] Niedd. Disponível em: http://www.nied.unicamp.br/. Acessado em: 17/04/2016.

[7] Oliveira, Z. C. Uma interpretação geométrica do MDC. Revista do Professor de Matemática (RPM), n. 29.

[8] Papert, S. Logo, computadores e educação. Tradução de José Armando Valente. 3ạ ed. São Paulo: Editora Brasiliense, 1985.

[9] Ponte, J. P. \& Canavarro, P. Matemática e novas tecnologias. Lisboa: Universidade Aberta, 1997.

[10] Valente, J. A. O professor no ambiente Logo: atuação e formação. José Armando Valente (ORG). Campinas, SP: UNICAMP/NIED, 1995. 


\section{Capítulo 18}

(Des)aproximações entre teoria e prática na formação de professores de matemática da UFMS CPTL

\section{Gerson dos Santos Farias}

Paulo Fioravante Giareta

Eugenia Brunilda Opazo Uribe

Resumo: 0 presente artigo discute a formação inicial do professor de Matemática, em busca de perceber as intencionalidades da articulação teoria e prática na construção do ser professor, a partir da análise do Projeto Pedagógico do Curso ofertado na UFMS Universidade Federal de Mato Grosso do Sul, CPTL - Campus de Três Lagoas. A pesquisa vincula as categorias de ensino, pesquisa e extensão, inerentes à pedagógica universitária, às categorias saberes docentes, prática docente e identidade docente, amplamente evidenciadas como características da formação de professores que ensinam matemática, por autores como Shulman (1996), Fiorentini et al (1998), Tardif (2002) e Candau e Lelis (1995). Metodologicamente, a pesquisa se estrutura como exercício dialético, por meio da Análise Documental, capaz de indicar as características manifestas e as intencionalidades nem sempre explícitas nas normatizações e projetos de formação de professores. 0 trabalho aponta para indícios de (des)articulação teoria e prática, identificados pelo referido alcance das categorias de análise.

Palavras-chave: Teoria e Prática, Formação de Professores, Licenciatura em Matemática Educação Matemática. 


\section{INTRODUÇÃO}

A formação inicial do professor tem sido tema de diversos estudos, como por exemplo, o documento intitulado Diretrizes Curriculares para o Ensino de Matemática: uma proposta da Sociedade Brasileira de Matemática SBM (2015), que ao se debruçar sobre o desafio da formação do professor de Matemática busca apresentar subsídios para a construção de espaços de diálogo e de proposições com vista à elaboração de uma proposta curricular nacional de ensino de Matemática.

Nessa direção, vale destacar que o curso de Licenciatura favorece o desenvolvimento profissional dos futuros professores de Matemática, ou seja, em meio a diversos aspectos formativos, é fundamental refletir acerca de quais conhecimentos são necessários para exercício da profissão docente?

Este trabalho, vinculado ao GForP - Grupo de Estudos e Pesquisa em Formação de Professores, objetiva explicitar indicadores da articulação teoria e prática, a partir da análise do Projeto Pedagógico do Curso de Matemática - Licenciatura da UFMS/CPTL, com a produção de conhecimento científico sobre a caracterização político-pedagógica da formação do professor de Matemática, a partir da pedagogia universitária.

Nas palavras de Cunha (2004) a pedagogia universitária é um campo polissêmico de produção e aplicação dos conhecimentos pedagógicos na educação superior, pressupondo conhecimentos na área do currículo e da prática pedagógica que incluem as formas de ensinar e aprender, articulando as dimensões do ensino e da pesquisa nos espaços de formação.

A pesquisa se estrutura metodologicamente como exercício dialético, por intermédio da Análise Documental (FIORENTINI; LORENZATO, 2006), capaz de indicar as características manifestas e as intencionalidades nem sempre explícitas nas normatizações e projetos de formação de professores. Por meio de categorias já indicadas no texto e aqui sistematizadas como: concepção de ensino; concepção de pesquisa; e concepção de extensão, recebendo aporte teórico de autores como Fiorentini, Nacarato \& Pinto, (1999); Fiorentini et al (1998); Tardif (2002); Habermas (1989); Castro (2002); Candau e Lelis (1995) e Shulman (1986).

Considerando a análise do PPC - Projeto Pedagógico do Curso, a partir das categorias indicadas, aponta para indícios de (des)articulação entre a teoria e a prática, evidenciado pela falta de clareza e caracterização genérica da proposta de formação de professores no Curso de Licenciatura em Matemática da UFMS/CPTL. Até mesmo, pela ausência de cuidado quanto à construção da identidade docente, uma vez que o projeto do curso se exime da própria indicação da dimensão extensão, enquanto forma de aproximação com o campo de atuação do futuro professor de Matemática.

\section{LICENCIATURA EM MATEMÁTICA E A FORMAÇÃO DE PROFESSORES: A BUSCA POR CATEGORIAS DE ANÁLISE.}

A desarticulação formativa tem despertado intensa discussão na literatura de pesquisa, na área, nas últimas décadas:

Verificamos que a dicotomia entre teoria e prática já aparece nos anos 30, quando havia uma estrutura curricular que estabelecia uma hierarquia entre conteúdo e metodologia. Nos anos 60, com a Reforma Universitária, reforça-se ainda mais a separação entre disciplinas específicas e as pedagógicas. 0 modelo da racionalidade técnica, nos anos 70 , privilegia a formação teórica e a prática é vista como aplicação da teoria. Nos anos 80 , o problema da dicotomia entre a teoria e a prática foi muito discutido devido às influências das reflexões levantadas por Vásquez. Em 1990, embora passe a ser enunciada a relação teoria-prática como eixo articulador do currículo, e em 1996, no art. 61 da LDB, seja prevista a 'associação entre a teoria e a prática', os problemas da dicotomia permanecem os mesmos. (PEREIRA, 2005, p. 87)

Assim, alguns conteúdos apresentam dificuldade quando vistos na perspectiva da articulação teoria e prática, apresentando limitações para responder às especificidades da prática no ambiente da universidade e do ambiente da escola básica. 0 conhecimento científico ministrado nos espaços acadêmicos, comumente, dista da linguagem a ser ensinada nas escolas. 0 que figura não ser suficiente a apropriação isolada de um conjunto de conceitos teóricos ou um conjunto de conhecimentos metodológicos acessados durante a graduação. 
Nesse sentido a formação do professor, na perspectiva da articulação teoria e prática, dar-se-á por inúmeros fatores norteadores a serem olhados, tanto de maneira isolada quanto conjunta, no qual a construção da identidade docente para exercício do ofício se constitui na complexidade da junção de saberes e práticas.

Dentro desta perspectiva, vale ressaltar que de acordo com Candau e Lelis (1995) essa desarticulação, acontece devido à visão dicotômica da relação entre teoria e prática, ou seja, compreendida na maioria dos espaços formativos, como polos distintos e separados. Para isso, as autoras propõem a visão de unidade, nesse sentido, a teoria "[...] deixa de ser um conjunto de regras, normas e conhecimentos sistematizados a priori, passando a ser formulada a partir das necessidades concretas da realidade educacional" (CANDAU; LELIS, 1995, p. 59).

E se tratando do curso de Licenciatura em Matemática e a formação do professor inserido neste meio, Shulman (1986) destaca que o conhecimento pode ser dividido em três categorias: conteúdo específico, conteúdo pedagógico e conteúdo curricular. Seguindo o raciocínio do autor, o conhecimento específico potencializa o professor a dominar o conteúdo a ser trabalhado em sala de aula e suas demandas, pois a Matemática possui uma série de particularidades para a construção do saber matemático.

O conhecimento pedagógico, por sua vez, perpassa um conjunto de saberes não restritos ao traquejo do conteúdo específico, sendo capaz de articular movimentos de exemplificação, ilustração, demonstração, em síntese, trata do modo de se ensinar. Por fim, ainda sobre a influência de Shulman (1986), o conhecimento do conteúdo curricular se refere às disciplinas ministradas pelo professor: estruturas, organização, livros didáticos, materiais de apoio institucional e suas demandas.

Acerca disso, com enfoque na formação inicial do professor que ensina Matemática, é preciso considerar: Quais são os conhecimentos necessários para exercício da profissão docente?

Palhano (1995) ajuda a compreender que, além dos conhecimentos específicos, a formação do professor é constituída por meio de suas experiências ao longo da vida. Os determinantes históricos, que afetam a apropriação dos conhecimentos e a compreensão da prática do professor, não podem ser acomodados na simples transmissão dos conhecimentos já constituídos, mas pressupõe compreender a formação como um processo complexo de inter-relações no espaço social e político.

Para Fiorentini et al (1998), a vinculação das relações teórico-práticas mediadas pela complexidade político-pedagógica, na formação do professor, nos aproxima das categorias saber e conhecimento, indicadas também, por Tardif (2002) ao reconhecer que as categorias saber e conhecimento abrangem competências, habilidades e atitudes, isto é, aquilo que muitas vezes foi chamado de saber, saber-fazer e saber-ser.

Convém destacar que, neste contexto, há uma diferenciação do saber docente com o paradigma da racionalidade técnica:

O saber docente é um saber reflexivo, plural e complexo porque histórico, provisório, contextual, afetivo, cultural, formando uma teia, mais ou menos coerente e imbricada, de saberes científicos - oriundos das ciências da educação, dos saberes das disciplinas, dos currículos - e de saberes da experiência e da tradição pedagógica (Fiorentini, Nacarato \& Pinto, 1999, p. 55).

A afirmativa de que a articulação teoria e prática é uma conquista construída ao longo do tempo, a medida que aperfeiçoa a sua prática, também vale para as denominadas categorias saberes e conhecimentos, pois as intencionalidades político-pedagógicas são construídas diariamente, por meio de constante atualização no processo de formação e prática do professor. Sendo o saber docente, portanto, um saber complexo, composto por um conjunto de elementos, envolvendo profissionais inseridos em diferentes contextos sócio-histórico-culturais. Sendo assim, suas trajetórias de vida repercutem diretamente no processo de construção da identidade desse professor.

A partir desta perspectiva é possível identificar os professores como técnicos e como profissionais (HABERMAS, 1989), pois o exercício da profissão gera tensões, entre a identidade pessoal e a identidade profissional, levando à compreensão de uma espécie de cobrança em torno do ser um bom professor. Questionando inúmeras situações, pensamentos, sentimentos e intuições em relação ao papel profissional inserido em sala de aula, marcado pela transição de sua condição de aluno à condição de professor.

Segundo Habermas (1989) os professores como técnicos se preocupam exclusivamente na transmissão do conhecimento científico, adquiridos em cursos e institutos, por meio da linguagem da racionalidade técnica. Por outro lado, os professores como profissionais buscam desenvolver nos alunos a capacidade de 
pensamento crítico e responsabilidade cívica, exigindo deste professor flexibilidade, criatividade e atenção continuada aos processos de investigação.

Assim, a tarefa de professor exige maleabilidade, em razão da aquisição do conhecimento ser um processo contínuo e o currículo torna-se mais abrangente e envolvente, em virtude dos saberes docentes. Ou seja, ser professor está ligado a constante (re)significação e (re)constituição de saberes em função do contexto em que esse realiza a ação docente, diferentemente de estar professor que se relaciona com o reproduzir comportamentos já pré-estabelecidos, preocupado na maioria das vezes com técnicas, mutáveis a cada nova classe de alunos.

Constatação que ajuda Castro (2002, p. 31) evidenciar, em relação à construção da identidade docente, "um processo criativo de atribuir novos significados a partir do já conhecido, validando um novo olhar sobre o contexto em que o sujeito está imerso", em outras palavras, um processo dinâmico, complexo e inconcluso.

A capacidade atribuída ao PPC de orientar a proposta formativa do curso vincula-o à presente pesquisa como documento norteador das categorias/concepções de ensino, pesquisa e extensão, ilustrativas dos necessários saberes, práticas e identidade docente, aqui, apresentados como características centrais no processo de formação do professor de Matemática.

Assim, a análise do PPC de Matemática objetiva elucidar a referida caracterização pela leitura detalhada do projeto por meio das categorias ensino, pesquisa e extensão, enquanto categorias inerentes à pedagogia universitária que acomoda e regula a oferta do Curso.

\section{LICENCIATURA EM MATEMÁTICA E A FORMAÇÃO DE PROFESSORES: UM OLHAR SOBRE O PPC DE MATEMÁTICA.}

0 Curso de Matemática da UFMS - Universidade Federal de Mato Grosso do Sul, CPTL - Campus de Três Lagoas obteve reconhecimento oficial através da Resolução no 19, COUN, de 7 de julho de 1986, sendo implantado no ano seguinte e reconhecido pela Portaria no 1.023, MEC, de 26 de outubro de 1990.

O PPC - Projeto Pedagógico do Curso apresenta como objetivo central a formação profissional inicial de professores de Matemática para o Ensino Básico (6ำ ao 9o ano do Ensino Fundamental e todas as séries do Ensino Médio), com sólida formação em Matemática e uma formação pedagógica que permita uma visão abrangente do papel de educador com capacidade de trabalhar em equipes multidisciplinares. (UFMS, 2019, p. 10)

0 alcance e a caracterização deste objetivo, no âmbito da proposta formativa da universidade, são articulados e garantidos pelo próprio PPC, ao figurar como documento capaz de sintetizar as intencionalidades político-pedagógicas do curso.

Essas intencionalidades se expressam, no PPC, pelas dimensões de: concepção do curso, fundamentos da gestão pedagógica e administrativa, perfil dos formandos, competências e habilidades, conteúdos curriculares de formação geral e os conteúdos de formação específica, formato dos estágios e das atividades complementares e estrutura e formas de avaliação do curso.

A leitura cuidadosa do Projeto Pedagógico do Curso de Licenciatura em Matemática da UFMS/CPTL buscando identificar como é apresentada a categoria ensino, relacionada ao conteúdo específico, revela dispor de 198 menções ao longo do texto. Conforme quadro 1. 
Quadro 1 - Categoria Ensino

\begin{tabular}{|c|c|c|}
\hline $\begin{array}{c}\text { Seções do PPC em que aparece o conceito } \\
\text { Ensino }\end{array}$ & Subseções do PPC em que aparece o conceito Ensino & Total \\
\hline 1. identificação do curso & $\begin{array}{l}\text { 1.5. Modalidade de ensino: Presencial } \\
\text { 1.13. Forma de ingresso }\end{array}$ & 3 \\
\hline 2. Fundamentação Legal & & 2 \\
\hline 3. Contextualização & 3.1. Histórico da UFMS & 8 \\
\hline 4. Necessidade Social do Curso & $\begin{array}{l}\text { 4.1. Indicadores socioeconômicos da população da } \\
\text { mesorregião } \\
\text { 4.3. Análise da oferta do curso na região }\end{array}$ & 8 \\
\hline 5. Concepção do Curso & $\begin{array}{l}\text { 5.1.1 Técnica } \\
\text { 5.1.2 Política } \\
\text { 5.3. Estratégias para integração das diferentes } \\
\text { componentes curriculares } \\
\text { 5.4. Perfil desejado do egresso } \\
\text { 5.5 Objetivos } \\
\text { 5.6 Metodologias de ensino } \\
\text { 5.7. Avaliação }\end{array}$ & 30 \\
\hline 6. Administração Acadêmica do Curso & $\begin{array}{l}\text { 6.1. Atribuições do colegiado do curso } \\
\text { 6.4. Organização acadêmico-administrativa } \\
\text { 6.5. Atenção aos discentes }\end{array}$ & 18 \\
\hline 7. Currículo & $\begin{array}{l}\text { 7.1. Matriz curricular do curso } \\
\text { 7.2. Quadro de semestralização } \\
\text { 7.3. Tabela de equivalência das disciplinas } \\
\text { 7.6. Bibliográgia básica e complementar } \\
\text { 7.7. Política de implementação da nova matriz currilar }\end{array}$ & 97 \\
\hline 8. Políticas & $\begin{array}{l}\text { 8.1. Capacitação do corpo docente } \\
\text { 8.4. Atendimento aos requisitos legais e normativos: } \\
\text { Relações étnico-raciais, direitos humanos e educação } \\
\text { ambiental }\end{array}$ & 3 \\
\hline 9. Sistema de Avaliação & 9.1. Sistema de avaliação do processo formativo & 2 \\
\hline $\begin{array}{l}\text { 10. Atividades Acadêmicas Articuladas ao } \\
\text { Ensino de Graduação }\end{array}$ & $\begin{array}{l}\text { 10.1. Atividades orientadas de ensino } \\
\text { 10.5. Estágio obrigatório e não obrigatório } \\
\text { 10.7. Participação do corpo docente nas atividades } \\
\text { acadêmicas } \\
\text { 10.8. Práticas de ensino (específico para cursos de } \\
\text { medicina) } \\
\text { 10.9. Prática de ensino na área da saúde } \\
\text { 10.10. Prática de ensino como componente curricular }\end{array}$ & 21 \\
\hline $\begin{array}{l}\text { 11. Desenvolvimento de Materiais } \\
\text { Pedagógicos }\end{array}$ & & 2 \\
\hline 12. Infraestrutura Necessária ao Curso & & 1 \\
\hline $\begin{array}{l}\text { 13. Plano de Incorporação dos Avanços } \\
\text { Tecnológicos para o Ensino de Graduação }\end{array}$ & & 2 \\
\hline 15. Referências & & 1 \\
\hline
\end{tabular}

Não obstante, a expressiva menção da categoria ensino no PPC de Licenciatura em Matemática, de imediato, é possível afirmar que em nenhum momento apresenta preocupação quanto a explicitar e caracterizar o que se entende por ensino. 
O documento toma posse do conceito de ensino, ao longo de todo o texto, sem antes explicitar seu alcance, espelhando, apenas, uma função formal, conforme indicado na Concepção de Curso, no subitem Política, o seguinte fragmento:

O curso de Licenciatura em Matemática tratará destas questões de modo transversal, sem, contudo, deixar de ter momentos nos quais se faça a sistematização destes campos conceituais. São eles: 1. História do desenvolvimento das teorias políticas; 2. História dos sistemas de educação no Brasil; 3. O Ensino e sua relação com o desenvolvimento econômico e social (UFMS, 2019, p. 07).

Ao eximir-se do compromisso de explicitar o alcance e as características da categoria ensino, o PPC parece abrir possibilidades para proposições formativas centradas na abordagem tecnicista da formação do professor de Matemática. Uma vez que o próprio documento define que se espera formar o professor com "uma base sólida de conhecimentos e técnicas matemáticas" (UFMS, 2019, p. 10).

Percebe-se, até mesmo, o apego do PPC, a uma adjetivação específica, ao ensino de algo, a caracterização própria de uma ciência. Acerca disso, vale destacar o que o documento expressa quanto a definição do Perfil desejado do Egresso:

Considerando este contexto, o curso de Matemática - Licenciatura/CPTL deve garantir que seus egressos tenham: Uma base sólida de conhecimentos e técnicas matemáticas bem como sua prática pedagógica; Uma formação pedagógica voltada para o ensino de Matemática; Uma compreensão do contexto histórico e sociocultural em que a Matemática e seus futuros alunos estão situados; A inquietação de buscar novas metodologias para ensinar Matemática, seja incentivado e entusiasmado pela sua beleza intrínseca ou pelas suas múltiplas aplicações; [...] (UFMS, 2019, p. 10).

Novamente, há apontamentos essenciais para a formação do futuro professor de Matemática, descrevendo qual o perfil desejado do egresso do curso de Licenciatura em Matemática. Contudo, quando a categoria ensino é mencionada, há preocupação em demonstrar o ensino de uma ciência, o que de certa forma pode limitar a compreensão em sua totalidade.

O PPC apresenta, também, um movimento de aproximação do conceito de ensino com as matrizes de competência e habilidade, propondo que o curso se comprometa em mobilizar saberes, pelo exercício do ensino, objetivando o desenvolvimento de determinados comportamentos com potencial de aplicabilidade. Bem como apresentado no Perfil desejado do Egresso, "o futuro professor deve atentar para algumas funções básicas que nortearão o seu papel no processo de ensinar Matemática [...]. São elas: Organizador; Facilitador; Mediador; Incentivador; Avaliador" (UFMS, 2019, p. 10).

Finalmente, é possível identificar um caráter genérico na forma de apresentação da categoria ensino ao longo do texto do PPC, conferindo uma característica formal. Como expresso no seguinte trecho - "a unidade responsável por orientar as Coordenações de Curso e outros setores acadêmicos em procedimentos e normativas relativas ao ensino de graduação (UFMS, 2019, p.14).

Embora o relevante conjunto de menções da categoria ensino no Projeto Pedagógico do Curso, não há percepção de qualquer preocupação com a caracterização e significação da dimensão ensino, que é compreendida como parte atuante no processo de construção do saber docente, ficando fragilizada. Dificultando, portanto, a própria vinculação do curso com o compromisso de garantir, na formação do professor de Matemática, o acesso ao conhecimento/conteúdo específico, na perspectiva proposta por Shulman (1986).

Para a categoria pesquisa o PPC repete a estratégia indicada na categoria ensino, dispondo de 15 menções, desobrigando-se de explicitar ou caracterizar o que se entende, no âmbito do curso, por pesquisa. Conforme quadro 2 . 
Quadro 2 - Categoria Pesquisa

\begin{tabular}{|l|l|c|}
\multicolumn{1}{|c|}{$\begin{array}{c}\text { Seções do PPC em que aparece o } \\
\text { conceito Pesquisa }\end{array}$} & \multicolumn{1}{c|}{$\begin{array}{c}\text { Tubseções do PPC em que aparece o conceito Pesquisa } \\
\text { 3.3. Histórico do Curso }\end{array}$} \\
\hline 3. contextualização & $\begin{array}{l}\text { 6.4. Organização acadêmico-administrativa } \\
\text { 6.5. Atenção aos discentes }\end{array}$ & 5 \\
\hline 6. Administração Acadêmica do Curso & 7.6. Bibliográfia básica e complementar & 6 \\
\hline 7. Currículo & $\begin{array}{l}\text { 9.1. Sistema de avaliação do processo formativo } \\
\text { 9.4. Projeto institucional de monitoramento e avaliação } \\
\text { do curso }\end{array}$ & 2 \\
\hline 9. Sistema de Avaliação & \multicolumn{1}{|c|}{ Total de menções: 15 } & 1 \\
\hline $\begin{array}{l}\text { 11. Desenvolvimento de Materiais } \\
\text { Pedagógicos }\end{array}$ & \multicolumn{1}{|c|}{ Fonte: Organizado pelos autores } \\
\hline
\end{tabular}

A falta de clareza ou compromisso com a definição e delineamento de alcance do conceito de pesquisa resulta no esvaziamento do papel da pesquisa, da reflexão, da investigação na formação do professor de matemática.

Direcionando também para uma pró-formalidade no uso do conceito de pesquisa, ou seja, abordando de maneira restrita, atendendo a uma formalidade jurídica. Materializada no seguinte traço:

[...] colaborando com o levantamento das demandas do Curso quanto à distribuição de encargos docentes, levantamento de demandas de Professores para o curso, organizando o uso do espaço físico, divulgando e orientando os docentes quanto às diretrizes e normas relacionadas á área de ensino, pesquisa e extensão (UFMS, 2019, p.16).

A pró-formalidade se mescla com o aspecto formal, propriamente dito, apresentado no decorrer do texto como complemento narrativo, para indicar movimentos institucionais frente ao curso facilmente percebido nos seguintes trechos:

Existem materiais pedagógicos mais simples e que podem ser desenvolvidos pelos próprios acadêmicos sob supervisão do professor responsável no decorrer da disciplina, bem como através de projetos de ensino, pesquisa e extensão, utilizando para isto o Laboratório de Ensino de Matemática (UFMS, 2019, p.48).

Garantindo o fluxo do documento com o uso da categoria pesquisa de maneira a atender uma demanda textual, para contemplar narrativas, porém sem compromisso com a caracterização e significação do conceito pesquisa.

Resulta a constatação de que as menções à categoria pesquisa, no Projeto Pedagógico do Curso, não possibilitam perceber qualquer preocupação com a função educativa da pesquisa na proposta de formação do professor de matemática, restando evidente desarticulação entre teoria e prática, não estabelecendo relação da pesquisa com o conteúdo pedagógico proposto por Shulman (1986).

A aproximação da categoria extensão com as definições inerentes à formação do professor de matemática exige reconhecer a articulação e contribuição da extensão na articulação teoria e prática, tendo em vista a construção da identidade docente. Mas a análise do PPC aponta para uma estratégia recorrente na organização do documento, que é o não compromisso com a definição de alcance e caraterização das categorias analisadas, também da categoria extensão.

A categoria extensão é praticamente nula no documento, dispondo de 11 menções ao longo do texto. Conforme quadro 3. 
Quadro 3 - Categoria Extensão

\begin{tabular}{|c|c|c|}
\hline $\begin{array}{l}\text { Seções do PPC em que aparece o } \\
\text { conceito Extensão }\end{array}$ & $\begin{array}{l}\text { Subseções do PPC em que aparece o conceito } \\
\text { Extensão }\end{array}$ & Total \\
\hline 3. contextualização & 3.3. Histórico do Curso & 2 \\
\hline 6. Administração Acadêmica do Curso & $\begin{array}{l}\text { 6.4. Organização acadêmico-administrativa } \\
\text { 6.5. Atenção aos discentes }\end{array}$ & 5 \\
\hline 7. Currículo & 7.6. Bibliográfia básica e complementar & 1 \\
\hline $\begin{array}{l}\text { 10. Atividades Acadêmicas Articuladas } \\
\text { ao Ensino de Graduação }\end{array}$ & $\begin{array}{l}\text { 10.3. Atividades de extensão } \\
\text { 10.7. Participação do corpo docente nas atividades } \\
\text { acadêmicas }\end{array}$ & 2 \\
\hline $\begin{array}{l}\text { 11. Desenvolvimento de Materiais } \\
\text { Pedagógicos }\end{array}$ & & 1 \\
\hline \multicolumn{3}{|c|}{ Total de menções: 11} \\
\hline
\end{tabular}

Quando encontrada, parece receber uma funcionalidade secundária, expressa como adendo complementar, vinculada, por exemplo, ao título de uma disciplina: "Profissão Docente: Identidade, Carreira e Desenvolvimento Profissional" (UFMS, 2019, p.41).

A definição do alcance e caracterização da categoria extensão, no PPC de Licenciatura em Matemática, se apresenta inviabilizada. Fragilizando a própria definição do papel da extensão na formação de professores, que a compreende como fator que integra e confere identidade ao professor ao articular a teoria aprendida e produzida nas academias e as práticas docentes realizadas pelos candidatos à docência.

\section{CONSIDERAÇÕES}

Portanto do ponto de vista da contribuição da proposta do projeto pedagógico do curso de Licenciatura em Matemática para a formação do professor, buscando compreender como ele se apropria do conhecimento específico, conhecimento pedagógico e conhecimento curricular, transpassados em saber, prática e identidade docente atrelados ao ensino, pesquisa e extensão, cuidadosamente analisados no Projeto Pedagógico do Curso, é possível concluir que não temos uma contribuição clara para a formação do futuro professor de matemática da UFMS/CPTL.

Visto que no decorrer do texto, torna-se nítida a existência de uma visão generalista da categoria ensino, preocupada essencialmente com o ensino de um conceito científico, priorizando competências/habilidades em detrimento da construção do saber docente. Já a categoria pesquisa se comporta no projeto pedagógico de maneira pragmática, ou seja, como forma de atender a uma formalidade jurídica.

Por fim, uma não definição em relação à categoria extensão, revelando indícios de (des)articulação entre a teoria e prática, sendo assim não existe uma correlação complementar na formação do professor que ensina Matemática. Logo esta iniciativa fornece aos formadores um campo aberto às discussões, promovendo reflexões acerca da formação inicial, em busca de contribuir para o desenvolvimento profissional dos futuros professores que ensinam Matemática.

\section{REFERÊNCIAS}

[1] Candau, V. M.; Lelis, I. A. A relação teoria-prática na formação do educador. In: Candau, V. M. (Org.) Rumo a uma nova didática. Petrópolis: Vozes, p. 49-63,1995.

[2] Castro, F. C. de. Aprendendo a ser professor(a) na prática: estudo de uma experiência em prática de ensino de Matemática e estágio supervisionado. 2002. 149p. Dissertação. (Mestrado em Educação). Faculdade de Educação, Universidade Estadual de Campinas. Campinas. Disponível em: < http://repositorio.unicamp.br/jspui/handle/REPOSIP/253694 >

[3] Cunha, M. I. da. In: Morosini, Marilia (Org.). Enciclopédia da Pedagogia Universitária, MEC/Inep/Ries, 2006. v. 2.

[4] Farias, G. dos S.; Uribe, E. B. O; Giareta, P. F. Teoria e prática na formação de professores: Análise do projeto político pedagógico do curso de matemática da UFMS CPTL. In: VI Congresso Nacional de Educação (VI Conedu), 2019, Fortaleza. Anais Conedu. V. 1, 2019, issn 2358-8829 
[5] Fiorentini, D.; Lorenzato, S. Investigação em Educação Matemática: percursos teóricos e metodológicos. Campinas: Autores Associados, 2006.

[6] Fiorentini, D.; Nacarato, A. M.; Pinto, R. A. Saberes da experiência docente em matemática e educação continuada. Lisboa. Quadrante: Revista teórica e de investigação, Vol. 8, n. 1-2, 1999, p.33-60.

[7] Fiorentini, D.; Souza, A . J.; Melo, G. F. Saberes Docentes: Um Desafio para Acadêmicos e Práticos. In: Geraldi, C. (Org) Cartografias do Trabalho Docente: Professor(a)-Pesquisador(a). 1. ed.Campinas: Mercado das Letras, ALB, 1998, p. 307-335

[8] Habermas, J. Consciência Moral e Agir Comunicativo. Trad. Guido de Almeida. Rio de Janeiro: Tempo Brasileiro, 1989.

[9] Palhano, E. G. S. O saber docente: apontamentos para uma discussão. São Paulo, 1995. 158 f. Dissertação de Mestrado em História e Filosofia da Educação. Faculdade de Educação, PUC-SP.

[10] Pereira, P. S. A concepção de prática na visão de licenciandos de matemática. 2005. Tese (Doutorado em Educação Matemática) - Universidade Estadual Paulista, Rio Claro.

[11] Shulman, L. S. Those who understand: Knowledge growth in teaching. Educational Researcher, fev - 1986.

[12] Tardif, M. Saberes docentes e formação profissional. 4⿳ạ Ed. Rio de Janeiro: Vozes, 2002.

[13] Ufms. Projeto Político Pedagógico do Curso de Matemática - Licenciatura. Três Lagoas: CPTL, 2019. 


\title{
Capítulo 19
}

\section{A formação de professores de Matemática da rede estadual no processo de implementação do currículo do Estado de São Paulo (2008)}

\author{
Eliane Maria Vani Ortega \\ Maria Raquel Miotto Morelatti \\ Leny Rodrigues Martins Teixeira \\ Monica Fürkotter \\ Luiz Fernando Carvalho \\ Maria Cecília Fonçatti \\ Érika Aparecida Navarro Rodrigues \\ Oscar Massaru Fujita \\ Raquel Gomes de Oliveira
}

Resumo: A presente pesquisa tem por objetivo descrever e analisar o processo de formação de professores de Matemática da rede estadual de ensino do município de Presidente Prudente, ocorrido a partir de 2008, quando da implantação e implementação do "Currículo do Estado de São Paulo: Matemática e suas tecnologias". Trata-se de uma investigação qualitativa de delineamento analíticodescritivo que faz parte de uma pesquisa que teve como objetivo caracterizar a proposta do currículo, identificar e compreender a opção de uso do material curricular pelos professores e as ações de formação continuada realizadas para implantação do currículo. Inicialmente foi desenvolvida uma análise documental do material do currículo a partir de Cellard (2012), Lüdke e André (1986) e São Paulo (2012, 2014). A opção de uso do material pelos professores foi identificada utilizando parte dos dados coletados por um questionário respondido por 80 professores de Matemática de 24 escolas do município de Presidente Prudente. Neste texto analisamos o terceiro eixo, considerando os registros de atividades de formação realizadas na Diretoria de Ensino Região de Presidente Prudente (DERPP) e os dados do questionário, com a opinião dos professores sobre o tipo de formação recebida e a identificação da mais adequada para o êxito da implementação do currículo. Os dados foram categorizados com base na análise de conteúdo (Franco, 2005) e analisados consoante Gatti e Barreto (2011), Imbernón (2004, 2009), Marcelo Garcia (1999) e Canário (1998), entre outros. Os resultados apontam que a formação não se deu de forma universal e uniforme. Houve uma grande variação nos modos de acesso dos professores às informações e capacitações para o uso do material do currículo, ocorrendo online e, presencialmente, nas escolas e na DERPP. Segundo os professores, a formação ideal deveria privilegiar mais tempo com colegas de trabalho e troca de experiências e contemplar a formação para o uso da proposta.

Palavras-chave: Currículo de Matemática, Professores de Matemática da Educação Básica, Formação continuada. 


\section{INTRODUÇÃO}

Em 2008, a Secretaria de Educação do Estado de São Paulo (SEESP) iniciou processo de implantação de proposta curricular (São Paulo, 2012, 2014) por meio da utilização de material curricular padronizado distribuído para toda a rede de ensino abrangendo os níveis fundamental e médio.

Com o objetivo de analisar o processo de formação de professores proposto e desenvolvido durante a implantação e implementação do material curricular na percepção dos professores de Matemática do município de Presidente Prudente, propusemos uma pesquisa de natureza qualitativa, delineamento analítico-descritivo (Lüdke; André, 1986), com 80 docentes desse município, pertencente à Diretoria de Ensino - Região de Presidente Prudente (DERPP).

A pesquisa se desenvolveu a partir de três eixos. 0 primeiro diz respeito à análise documental do currículo proposto em 2008, segundo Cellard (2012), publicado por Ortega et al (2016). 0 segundo refere-se às percepções dos professores em relação às características do material e ao seu uso em sala de aula, cujos resultados foram publicados por Carvalho et al (2017) e Fujita et al (2018). 0 terceiro eixo, relatado neste artigo, tem como objetivo compreender como se deu o processo de formação dos professores de Matemática para a implementação do currículo proposto. Para a análise consideramos os registros de atividades de formação realizadas pela SEESP e DERPP e os dados do questionário com a opinião dos professores sobre as ações formativas realizadas. As respostas foram categorizadas com base na análise de conteúdo (Franco, 2005) e investigadas tendo como referencial teórico autores que tratam da formação continuada.

\section{FUNDAMENTAÇÃO TEÓRICA}

Ferry (1983) apresenta uma perspectiva complexa e dinâmica do processo de formação ao tratá-la como um processo de desenvolvimento pessoal, ou seja, é o sujeito que se forma, é ele que encontra a sua própria forma ao longo da vida. Por outro lado, embora o sujeito seja o centro da sua formação, ele se forma necessariamente pela mediação, que pode se apresentar de maneiras muito diversas como a própria ação dos formadores, as leituras, cursos e as várias circunstâncias da vida que envolvem os percalços da história de cada um e da sua relação com os outros. Visto dessa forma a formação precisa ser contínua e reflexiva.

A palavra formação apresenta muitos significados. Imbernón $(2004,2009)$ aborda a questão da formação como permanente, que possibilita o conhecimento profissional e que não se reduz à atualização científica, pedagógica e cultural do professor. Trata-se de um processo contínuo que ocorre em um cenário de grande complexidade, dados os diversos elementos de natureza social, pedagógica e científica que o compõem. Para esse autor tal complexidade não pode ser enfrentada individualmente.

Uma perspectiva individual de formação profissional em que não há espaço para a colaboração com a comunidade educativa torna o professor "um instrumento mecânico e isolado de aplicação, reprodução, com algumas competências limitadas à aplicação técnica em sala de aula" (Imbernón, 2004 p. 68). Sendo assim, algumas exigências da formação permanente aparecem: reflexão sobre a prática, autoavaliação, questionamento dos valores, equilíbrio entre a prática e a teoria, desenvolver nos professores conhecimentos, habilidades e atitudes para torná-los reflexivos e investigadores para compreender a educação e sua realidade, tendo em vista a sua reconstrução social (Zeichner, 1993).

Marcelo Garcia (1999) trata da formação contínua como desenvolvimento profissional. Segundo o autor é preciso valorizar o caráter contextual, organizacional e voltado para a mudança. Ele descreve alguns modelos de desenvolvimento profissional de professores fundamentados nas atividades de formação realizada: desenvolvimento profissional autônomo, desenvolvimento profissional baseado na reflexão, no apoio profissional mútuo, desenvolvimento profissional através do desenvolvimento e inovação curricular e a formação no centro e desenvolvimento profissional através de cursos de formação. Ainda que estes modelos estejam articulados, neste texto vamos explicitar os dois últimos.

No modelo de "desenvolvimento profissional através do desenvolvimento e inovação curricular e a formação no centro", estão incluídas atividades de formação em que os professores desenvolvem ou adaptam um currículo, desenham um programa ou participam de um processo de melhoria da escola. Esta modalidade está baseada no pressuposto de que os adultos aprendem a partir de um problema concreto, relativo ao seu trabalho, no qual está implicado. 
Assim, quando os professores se envolvem em projetos de inovação ocorrem mudanças significativas, ou seja, a implementação de um processo é também um processo de aprendizagem. Um projeto de inovação passa por diversas fases e para cada uma delas se exige um tipo de trabalho diversificado. Dependendo de como é trabalhada, a inovação pode ser formativa porque permite aos professores reverem suas posições educativas e didáticas, superando uma ação intuitiva.

0 envolvimento dos professores com o processo de inovação depende do valor que os professores atribuem a ela. Como sabemos, o princípio que move os professores é a prática, o que os leva a valorizar aquilo que os ajude a resolver um problema vivenciado no seu cotidiano. Além disso, o envolvimento do professor também depende das informações que ele tenha sobre as inovações nas quais está implicado.

Como diz Marcelo Garcia (1999), as mudanças no ensino e consequentemente o desenvolvimento profissional, não se dão por "geração espontânea". Este autor, citando Pink (1989), arrola barreiras que precisam ser ultrapassadas para a obtenção de êxito neste processo, resumidas a seguir: pouco tempo para planejamento e aprendizagem de competências e práticas docentes; tendência para procurar soluções rápidas; falta de apoio e continuidade por parte da Administração; poucos recursos; gerir o projeto a partir da Administração, e não da escola; desconsideração das limitações do conhecimento dos professores para concretizar o projeto; mudanças contínuas dos professores nas escolas; sobrecarga de tarefas e exigências; impedimentos burocráticos da escola; desconsiderar as diferenças entre escolas.

0 modelo de "desenvolvimento profissional através de cursos de formação" é o mais tradicional. Parte do pressuposto que os participantes podem transferir a teoria para a prática, podendo atender a uma ampla gama de necessidades dos professores, e atingir uma grande quantidade de pessoas ao mesmo tempo. As vantagens desse modelo se referem à possibilidade de aumento de conhecimento, à melhora nas competências, além de propiciar ao professor a oportunidade de escolher cursos do seu interesse, portanto, de gerir sua formação. Por outro lado, há desvantagens devidas a vários aspectos: caráter excessivamente teórico, dificuldades de adaptação às necessidades individuais dos participantes, desconsideração do conhecimento prático do professor, entre outras. Portanto, são mínimas as possibilidades de transferir esses conhecimentos para a realidade da escola e da sala de aula.

No Brasil, nos últimos vinte anos, houve um crescimento muito grande de propostas das mais variadas ordens que podem ser caracterizadas como formação continuada, abrangendo desde cursos de extensão até os de especialização oferecidos nas formas presencial, semipresencial e virtual. Esse crescimento, segundo Gatti (2008), se deve aos desafios enfrentados pelos sistemas de ensino quando da ampliação do acesso à escola por grande parte da população. Tais dificuldades, agravadas por mudanças na sociedade, em particular no mundo do trabalho, forjaram o discurso da necessidade de atualização e renovação constante para fazer jus à mudança.

A necessidade de formação continuada acabou sendo assunto não só para os profissionais em geral, como também para os da Educação, exigindo engajamento dos órgãos governamentais, traduzido em políticas nacionais e regionais de Educação visando aperfeiçoamento dos seus profissionais. Inicialmente, no entanto, em grande parte, as iniciativas públicas de formação continuada no setor educacional apresentaram um caráter compensatório (em relação à formação inicial), ao invés de oportunizar aperfeiçoamento dos profissionais da Educação para inovação na sua área, como foram o PROCAP (Minas Gerais, 1996) e o PEC (São Paulo, 1996-1998) (Gatti, 2008).

Além desses programas, foram criados o Programa de Formação de Professores em Exercício (Proformação), o PEC Formação Universitária (SEESP), o PEC Municípios, o Programa Pedagogia Cidadã (SP) e outros em parcerias com entidades civis como o Projeto Veredas (MG). Além desses programas, as políticas de formação têm desenvolvido projetos específicos de formação continuada com vistas à implementação de novas propostas pedagógicas ou curriculares criadas pelo MEC ou pelas Secretarias de Estado. Nesta linha podemos citar programas do MEC como Um salto para o futuro, Parâmetros em Ação, Proler, Gestar, Profa, Letra e Vida, Pró-letramento e Pnaic. No nível estadual, vários programas foram desenvolvidos em parceria com o Governo Federal ou de iniciativa da SEESP. A implementação do currículo do Estado de São Paulo iniciado em 2008 é um desses programas. 


\section{APRESENTAÇÃO E DISCUSSÃO DOS RESULTADOS}

\subsection{AÇÕES FORMATIVAS DA SEESP SOBRE O NOVO CURRÍCULO}

No Estado de São Paulo, uma ação vinculada à formação continuada de professores e política pública, identificou-se com a implementação da Proposta Curricular da SEESP enquanto parte do Programa São Paulo Faz Escola, criado no segundo semestre de 2007, a fim de estabelecer um currículo único para todas as escolas estaduais públicas paulistas. Nesta implementação ocorreu a utilização de materiais pedagógicos, compostos pelos Cadernos do Professor e do Aluno, organizados por disciplina, ano e bimestre, jornais e DVD que foram enviados às escolas com orientações específicas à equipe Gestora (Diretor, Vice-Diretor e Coordenador Pedagógico) e aos professores para a utilização nas aulas.

Em dezembro de 2007 a SEESP apresentou a nova Proposta Curricular, por meio de videoconferências, para Diretores de Escola, Assistentes Técnico-Pedagógicos (ATP) e Supervisores de Ensino. Também neste tempo, professores de Língua Portuguesa e de Matemática do Ensino Fundamental (Ciclo II) e do Ensino Médio foram convocados para receberem orientações de apoio quanto ao planejamento das atividades programadas para as seis primeiras semanas letivas de 2008, nas quais se utilizaria o Jornal do Aluno.

Ainda em 2007, foi alterado o calendário escolar e determinada a distribuição de materiais pedagógicos para garantir a implementação da proposta pedagógica. Em fevereiro de 2008, as escolas receberam, disponíveis também online, os vídeos da "Edição Especial da Proposta Curricular - Orientação para Professores", que apresentavam os princípios norteadores da elaboração do material pedagógico e sugeriam estratégias aos professores para sua utilização com os alunos, além de explicitarem o propósito curricular de desenvolver habilidades de leitura e interpretação de texto e as estruturas lógicomatemáticas.

A contextualização e a apresentação da Proposta Curricular do Estado de São Paulo foram realizadas pela SEESP, pela Coordenadora Geral da Proposta e por autores dos Cadernos do Professor somente para os Professores Coordenadores do Núcleo Pedagógico (PCNP). Também foi apresentado o curso "A Rede Aprende com a Rede”, oferecido aos professores por adesão, através de videoaulas, Fórum e Formulário Web, objetivando aprofundamento dos conceitos e teorias que norteiam tanto as Propostas Curriculares disciplinares como as metodologias indicadas nos materiais de apoio aos professores. 0 curso foi mediado pelos PCNP, que receberam orientações da SEESP por meio de videoconferências. Encontros presenciais tiveram como objetivo que os PCNP organizassem a formação continuada dos Professores Coordenadores das escolas e estes dos professores, em sua respectiva unidade escolar.

Em 2010, a Proposta Curricular tornou-se o currículo oficial do Estado de São Paulo, implementado a partir de orientações da SEESP e ações da Oficina Pedagógica das Diretorias de Ensino. Diante da promoção de cursos e de jornada extra docente, realizaram-se o estudo e a exploração das situações de aprendizagem propostas nos Cadernos do Professor e do Aluno. Um desses cursos, "Implementação do Currículo de Matemática - Ciclo II e Ensino Médio", foi organizado em quatro módulos, com temas específicos e realizados por semestre, entre 2010 e 2011. A realização do curso (modalidade online e presencial) por adesão do professor pode justificar por que, na DERPP, esta adesão não chegou a 30\% do total de professores de Matemática.

No decorrer dos anos de 2011 e 2012 foram oferecidas, pela DERPP, oficinas em horário de ATPC e orientações técnicas que objetivavam estudos e reflexões sobre as situações de aprendizagem propostas nos cadernos do professor e aluno. A partir de 2011 a SEESP criou o Curso Específico de Formação aos Ingressantes nas Classes Docentes do Quadro do Magistério, visando apresentar aos docentes, ingressantes na rede estadual, o currículo adotado pelo Estado. Este curso é obrigatório a todos os professores que ingressam na SEESP através do concurso público e está em sua sexta edição, ou seja, todos os professores que foram convocados até a última chamada em 2017 para assumirem seu cargo do concurso público são obrigados a realizar esse curso que aborda aspectos pedagógicos e específicos do currículo.

Em 2013 a SEESP estabeleceu a ação de formação continuada "Melhor Gestão, Melhor Ensino" aos professores de Língua Portuguesa e de Matemática de todas as unidades escolares que atendiam o Ensino Fundamental - Anos Finais. O curso teve início com um encontro presencial, por convocação docente. Posteriormente, ocorreram atividades em um ambiente virtual. 
Quadro 1: Ações formativas da SEESP e DERPP para professores de Matemática

\begin{tabular}{|c|c|c|c|c|c|}
\hline \multicolumn{2}{|c|}{ Formação } & \multirow{2}{*}{ Ano } & \multirow{2}{*}{$\begin{array}{l}\text { Modalidade e tipo de } \\
\text { evento (local) }\end{array}$} & \multirow{2}{*}{ Público-alvo } & \multirow{2}{*}{$\begin{array}{l}\text { Natureza da } \\
\text { participação }\end{array}$} \\
\hline Formação geral & Formação específica & & & & \\
\hline 1. Videoconferências & & $2007 / 2008$ & $\begin{array}{c}\text { À distância com } \\
\text { palestras online (DE e } \\
\text { escolas) }\end{array}$ & $\begin{array}{l}\text { Supervisores, } \\
\text { Diretores e } \\
\text { Professores } \\
\text { Coordenadores. }\end{array}$ & Convocação \\
\hline \multirow[t]{5}{*}{$\begin{array}{l}\text { 2. Formação com os } \\
\text { autores do Currículo }\end{array}$} & $\begin{array}{l}\text { 1. Formação com os } \\
\text { autores do Currículo }\end{array}$ & 2008 & \begin{tabular}{|c} 
Presencial com \\
palestras (Serra Negra- \\
SP)
\end{tabular} & PCNP & Convocação \\
\hline & $\begin{array}{l}\text { 2. Curso: A Rede } \\
\text { Aprende com a Rede }\end{array}$ & $2008 / 2009$ & $\begin{array}{l}\text { À distância com } \\
\text { videoaulas, fórum e } \\
\text { formulário WEB. }\end{array}$ & Professores e PCNP & Adesão \\
\hline & 3. Oficinas temáticas & $2009 / 2010$ & $\begin{array}{c}\text { Presencial com } \\
\text { vivência de situações } \\
\text { de aprendizagem } \\
\text { (escolas em ATPC) }\end{array}$ & Professores & Convocação \\
\hline & \multirow{2}{*}{$\begin{array}{l}\text { 4. Implementação do } \\
\text { Currículo de } \\
\text { Matemática - Ciclo II e } \\
\text { Ensino Médio }\end{array}$} & \multirow[t]{2}{*}{$2010 / 2012$} & $\begin{array}{c}\text { À distância com vídeo e } \\
\text { pesquisas e presencial } \\
\text { com vivência de } \\
\text { situações de } \\
\text { aprendizagem (DE) }\end{array}$ & Professores & Adesão \\
\hline & & & $\begin{array}{c}\text { Presencial com } \\
\text { palestras (São Paulo- } \\
\text { SP) }\end{array}$ & PCNP & Convocação \\
\hline \multirow[t]{2}{*}{$\begin{array}{l}\text { 3. Curso específico de } \\
\text { formação ao } \\
\text { ingressante como PEB } \\
\text { II }\end{array}$} & $\begin{array}{l}\text { 5. Curso específico de } \\
\text { formação ao } \\
\text { ingressante como PEB } \\
\text { II }\end{array}$ & 2011 - atual & $\begin{array}{c}\text { À distância e presencial } \\
\text { (DE) }\end{array}$ & $\begin{array}{c}\text { Professores } \\
\text { ingressantes no } \\
\text { Quadro do } \\
\text { Magistério }\end{array}$ & Convocação \\
\hline & $\begin{array}{l}\text { 6. Melhor Gestão, } \\
\text { Melhor Ensino }\end{array}$ & 2013 & $\begin{array}{c}\text { À distância com vídeos } \\
\text { e fórum e presencial } \\
\text { com oficinas temáticas } \\
\text { (DE) }\end{array}$ & Professores e PCNP & Convocação \\
\hline
\end{tabular}

Fonte: os autores

Analisando o Quadro 1, podemos perceber a perspectiva de formação que predominou nas ações da SEESP. A modalidade à distância predominou para a formação dos professores, tal como predominaram as formações, à distância e presencial, da formação específica, sendo estas pontuais, independentes e sem continuidade. Somente a formação específica "Oficinas temáticas", composta por três oficinas e realizada semestralmente, aconteceu nas unidades escolares, tendo oportunizado aos professores de Matemática vivências e reflexões sobre as situações de aprendizagem dos Cadernos do Professor e do Aluno.

\subsection{PERCEPÇÕES DOS PROFESSORES SOBRE AS AÇÕES FORMATIVAS}

Sobre as orientações recebidas para o uso do material do novo currículo e contribuições destas para o seu trabalho em sala de aula, dos 80 sujeitos, 72,5\% afirmaram que receberam orientações e 18,75\%, que não. Os demais sujeitos não responderam. As contribuições sobre as orientações estão categorizadas na Tabela 1. 
Tabela 1 - Contribuições das orientações recebidas pelos professores

\begin{tabular}{|c|c|c|c|}
\hline & Categorias & F & $\%$ \\
\hline \multirow{5}{*}{ Críticas à formação $(43,8 \%)$} & Quanto à natureza da formação & 25 & 26 \\
\hline & Quanto à prática do professor & 10 & 10,4 \\
\hline & Quanto a adequação à realidade da escola & 4 & 4,2 \\
\hline & Quanto à aprendizagem do professor & 2 & 2,1 \\
\hline & Quanto ao material & 1 & 1,1 \\
\hline \multirow{4}{*}{ Contribuição $(35,4 \%)$} & Formação geral do professor & 14 & 14,6 \\
\hline & Ensino & 13 & 13,5 \\
\hline & Aprendizagem dos alunos & 5 & 5,2 \\
\hline & Sem justificativa & 2 & 2,1 \\
\hline Tipo de orientação & & 20 & 20,8 \\
\hline Tota & & 96 & 100 \\
\hline
\end{tabular}

Fonte: questionário

Dentre as 96 respostas, 43,8\% referem-se a críticas à formação recebida, 35,4\% apresentam contribuições e $20,8 \%$ se limitam a tratar do tipo de orientação, sem indicar contribuições ou críticas.

Sinteticamente, ainda que grande parte dos professores $(72,5 \%)$ tenham afirmado que receberam algum tipo de formação sobre a proposta, apenas 35,4\% apontaram contribuições, no geral ligadas à formação geral dos professores $(14,6 \%)$ e ao ensino 13,5\%. Chama atenção que o maior número de respostas se ateve a críticas ao processo de formação $(43,8 \%)$ sobretudo quanto a natureza da formação (26\%) e a prática do professor $(10,4 \%)$.

A seguir, na Tabela 2, são apresentadas as dez categorias em que foram organizadas as 115 respostas fornecidas pelos professores quanto ao que faltou na formação para o uso do novo material.

Tabela 2 - 0 que faltou na formação recebida

\begin{tabular}{|c|c|c|c|}
\hline \multicolumn{2}{|l|}{ Categorias } & $\mathrm{F}$ & $\%$ \\
\hline \multirow{2}{*}{$\begin{array}{l}\text { Aspectos críticos da formação específica para uso do material, } \\
\text { relativas: }(53,04 \%)\end{array}$} & $\begin{array}{l}\text { as orientações para o uso do } \\
\text { material }\end{array}$ & 37 & 32,17 \\
\hline & ao modelo de formação & 24 & 20,87 \\
\hline Faltou capacitações/orientações/quantidade & & 13 & 11,30 \\
\hline Aspectos críticos relativos ao material (não falam da formação) & & 9 & 7,83 \\
\hline Não faltou nada & & 8 & 6,95 \\
\hline Aspectos ligados à formação inicial & & 7 & 6,09 \\
\hline Aspectos críticos relativos às condições de trabalho & & 6 & 5,22 \\
\hline Não houve formação & & 1 & 0,87 \\
\hline Não sei /resposta aleatória/em branco & & 10 & 8,70 \\
\hline Total & & 115 & 100,00 \\
\hline
\end{tabular}

Fonte: questionário

Da tabela acima podemos depreender que as respostas dos professores sobre o que faltou na formação sobre a proposta do currículo se concentram nos aspectos críticos da formação específica para uso do material (53,04\%), sendo eles relativos ao modelo de formação (20\%) e sobre as orientações para o uso do material $(32,2 \%)$. Chama atenção também as criticas feitas à quantidade insuficiente de capacitações para o uso do material (11,3\%).

Ao serem questionados sobre como deveria ser a formação para o uso do material, os professores forneceram 133 respostas categorizadas na Tabela 3. 
Tabela 3 - Como deveria ser a formação na visão dos professores

\begin{tabular}{|c|c|c|c|}
\hline \multicolumn{2}{|c|}{ Categorias } & $\mathrm{F}$ & $\%$ \\
\hline \multirow{3}{*}{ Formação continuada $(53,3 \%)$} & Formação para uso do material & 25 & 18,8 \\
\hline & Formação continuada/coletiva & 24 & 18 \\
\hline & Formação genérica & 22 & 16,5 \\
\hline \multicolumn{2}{|l|}{ Temporalidade/Frequência } & 17 & 12,8 \\
\hline \multicolumn{2}{|l|}{ Modalidade } & 13 & 9,8 \\
\hline \multicolumn{2}{|l|}{ Qualificação dos capacitadores } & 12 & 9 \\
\hline \multicolumn{2}{|l|}{ Autoformação } & 5 & 3,8 \\
\hline \multicolumn{2}{|l|}{ Formação inicial } & 3 & 2,3 \\
\hline \multicolumn{2}{|l|}{ Em branco } & 10 & 7,5 \\
\hline \multicolumn{2}{|l|}{ Resposta aleatória } & 2 & 1,5 \\
\hline \multicolumn{2}{|c|}{ Total } & 133 & 100 \\
\hline
\end{tabular}

Fonte: questionário

Em relação ao tipo de formação mais adequada, segundo os professores, fica nítida a escolha pela formação continuada (53,3\%) com destaque para uma formação coletiva (18\%) e para o uso do material $(18,8 \%)$. Novamente as respostas apontam a importância da frequência das ações de capacitação $(12,8 \%)$.

\section{CONCLUSÕES}

Os dados levantados pelos questionários são bastante elucidativos em relação à percepção dos professores sobre a formação recebida para implementação do currículo.

Os professores, em grande parte, admitem ter recebido formação, embora também tenha ficado evidente que as ações realizadas tenham deixado muito a desejar, pois, ao responderem sobre a formação, os professores indicaram algumas contribuições relativas à formação geral e ao ensino, mas salientaram críticas ao processo de formação, relativas ao modelo de formação ou à ausência de articulação com a prática docente. De fato, para os professores, faltou uma formação que os habilitasse para o uso do material, o que não foi possível, tanto pelo tipo de formação desenvolvida, quanto pela quantidade insuficiente de ações formativas.

Essas críticas foram corroboradas quando os professores apontaram as características de uma formação adequada: ser contínua, frequente, coletiva para propiciar trocas entre os pares e direcionada ao uso do material, portanto articulada à prática docente.

Em síntese, podemos depreender da fala dos professores uma crítica ao modelo de formação que acompanhou o processo de implementação do currículo do Estado de São Paulo. Ao observar as ações formativas realizadas no âmbito da DERPP ou da SEESP, conforme Quadro 1, podemos compreender as críticas feitas pelos professores.

Em primeiro lugar, é preciso considerar que o modelo de formação adotado tinha como objetivo implantar uma inovação curricular, do que decorre o caráter diretivo que permeou todo o processo. Nestes moldes a maior parte da formação teve um caráter genérico, oferecida para professores convocados, em grande parte on line, com base no modelo de multiplicadores, responsáveis por reproduzir orientações recebidas dos especialistas. Nesse sentido, a Proposta Curricular da SEESP, com atividades didáticas não elaboradas a partir de demandas escolares e à margem de participações de professores, evidenciou uma concepção de formação docente que desconsidera as condições de formação descritas por Ferry (1983), impossibilitando ao professor se envolver, tendo o sentido de pertença na implementação de um novo currículo, que necessariamente deveria ser composto por espaços escolares de reflexão, individual e coletiva, com conteúdos de reflexão a partir do vivido em sala de aula e na escola.

Relativamente às perspectivas de formação de professores (técnica e prática), que subsidiaram a elaboração e a implementação da proposta curricular, mesmo que se considerem estados de intersecção entre elas (ZEICHNER, 1983), a coordenação entre as modalidades de ações da SEESP e os resultados apresentados nesta pesquisa sugerem mais suas limitações do que suas possibilidades. Isto porque as ações evidenciaram características da perspectiva técnica, ao considerar o professor como um aplicador de atividades, devendo ter competências treinadas do alcance de resultados escolares eficazes. 
Em segundo lugar, as ações formativas realizadas não constituíram um processo contínuo, vivenciado coletivamente. Como aponta Imbernón (2004), os problemas educacionais são de alta complexidade, e exigem ser tratados por uma coletividade colaborativa, sem o que a formação se torna precária, porque mecaniza o trabalho do professor.

Em terceiro lugar a formação foi coordenada pelos órgãos administrativos e não capitaneada pela escola. Esse aspecto é salientado por Canário (1998, p. 9) quando afirma que "a escola é o lugar onde os professores aprendem a sua profissão". A escola é o espaço de formação da identidade docente porque nele se produzem as relações entre alunos e professores e entre os pares, engendrando modos de pensar, agir e interagir. É neste contexto que surgem os desafios da profissão e os modos possíveis de enfrentamento. Assim, modos de formação externos a esta realidade, ou que não a levem em consideração estão fadados à inoperância ou ao descrédito.

Concluindo, o currículo do estado de São Paulo desconsiderou que uma formação que pretende se realizar a partir da implantação de uma inovação curricular só é possível mediante o atendimento a certas condições, apontadas por Marcelo Garcia (1999), que abrangem provisão de recursos, mudanças estruturais nas escolas e nas condições de trabalho dos professores, assim como atendimento às necessidades de formação dos docentes por um processo contínuo de trabalho coletivo refletido com autonomia, no contexto de trabalho. Na mesma linha de raciocínio se configuram as conclusões de Gatti, Barreto e André (2011, p. 266) apontando que quanto maior a complexidade das políticas, maior pode ser a distância entre formuladores e implementadores. Isso ocorre tanto nas relações entre os níveis de implementação de políticas federais, estaduais e municipais, quanto no interior das redes de ensino, dado que "a aderência aos modelos de intervenção propostos é que definirá ou não o sucesso das políticas."

\section{REFERÊNCIAS}

[1] Canário, R. A escola: o lugar onde os professores aprendem. Revista de Psicologia da Educação. PUC. São Paulo, n. 6, p.9-27. 1998.

[2] Carvalho, L. F. et al O "novo" currículo do Estado de São Paulo: o que falam os professores de Matemática sobre o uso do material. In: EDUCERE - Congresso Nacional de Educação, XIII. Anais. Curitiba: Editora Universitária Champagnat. p, 2017. p. 1-13. Disponível em: http://educere.bruc.com.br/arquivo/pdf2017/26658_13351.pdf. Acesso em: 28 mai. 2018.

[3] Cellard, A. A análise documental. In: POUPARD, J. et al. A pesquisa qualitativa. Enfoques epistemológicos e metodológicos. São Paulo: ABDR, 2012, p.295-316.

[4] Ferry, G. Pedagogia de la formación. Buenos Aires: Centro de Publicaciones Educativas y Material didático, 1983.

[5] Franco, M. L.P. B. Análise do conteúdo. 2 ed. Brasília: Liber Livro, 2005.

[6] Fujita, O. M. et al. Professores de Matemática e percepções acerca do uso de materiais institucionalizados pelo currículo do Estado de São Paulo. Contexto \& Educação, ano 33, n. 105, mai./ago. 2018, p. 198-221.

[7] Gatti, B. A.; Barreto, E. B. S.; André, M. E. D. A. Políticas docentes no Brasil. Um estado da arte. Brasil: UNESCO, 2011.

[8] Gatti, B. A. Análise das políticas públicas para formação continuada no Brasil, na última década. Revista Brasileira de Educação \{online\}, v. 13, n. 37, jan./abr. 2008. p.57-70.

[9] Imbernón, F. Formação docente profissional. Formar-se para mudança e a incerteza. São Paulo: Cortez, 2004.

[10] Imbernón, F. Formação permanente do professorado: novas tendências. São Paulo: Cortez, 2009.

[11] Lüdke, M.; André, M. E. D. A. de. Pesquisa em educação: abordagens qualitativas. São Paulo: EPU, 1986.

[12] Marcelo Garcia, C. Formação de professores: para uma mudança educativa. Porto: Porto Editora, 1999.

[13] Ortega, E. M. V. et al. O currículo de Matemática do Estado de São Paulo: fundamentos didáticoepistemológicos e político-pedagógicos. In: Congresso Estadual Paulista sobre Formação de Educadores, XIII, Congresso Nacional de Formação de Professores, 3, 2016, Águas de Lindóia. Anais... São Paulo: UNESP/Prograd, 2016. p. $5442-5453$. 
[14] São Paulo (Estado) Secretaria da Educação. Currículo do Estado de São Paulo: Matemática e suas tecnologias / Secretaria da Educação; coordenação geral, Maria Inês Fini; coordenação de área, Nilson José Machado. 1. ed. atual. São Paulo: SE, 2012.72 p.

[15] São Paulo (Estado) Secretaria da Educação. Material de apoio ao currículo do Estado de São Paulo: caderno do professor; matemática, ensino fundamental - anos finais, 5a. série/6o. ano/Secretaria da Educação; coordenação geral, Maria Inês Fini; equipe, Carlos Eduardo de Souza Campos Granja, José Luiz Pastore Mello, Nílson José Machado, Roberto Perides Moisés, Walter Spinelli. São Paulo: SE, 2014.

[16] Zeichner, K. M. A formação reflexiva de professores, idéias e práticas. Lisboa: EDUCA, 1993. 


\section{Capítulo 20}

Os relatórios de estágios supervisionados de um curso de licenciatura em Matemática: Possibilidades de diálogos entre a avaliação e processos formativos

\section{Januária Araújo Bertani}

Resumo: Este artigo propicia uma reflexão sobre a importância dos registros realizados pelos alunos em uma das disciplinas de Estágio Supervisionado, em uma universidade estadual da Bahia. Enquanto proposta metodológica, recorremos à análise documental dos relatórios dos alunos. A produção propiciou entender algumas de suas concepções sobre a formação e a prática docente, como também, as expectativas, os planejamentos, as indecisões, mostrando que a prática docente é complexa e se faz no processo de ações que estão relacionadas com uma cultura escolar, mas, também, com a produção dos saberes docentes.

Palavras-chave: Formação docente em Matemática. Saberes docentes. Processo formativo. 


\section{QUAL A CONTRIBUIÇÃO DO ESTÁGIO PARA A FORMAÇÃO DOCENTE?}

As disciplinas de estágio supervisionado nos cursos de licenciatura em matemática podem ser representadas de várias formas, ou seja, podem ser concebidas priorizando somente a questão burocrática, a prática, e, ainda a relação teoria e prática enquanto um processo avaliativo e formativo. Por certo, a sua forma de ser trabalhada está intimamente relacionada com uma cultura escolar. A história cultural nos propicia entendermos melhor o conceito de cultura escolar que segundo Julia (2001) produz normas e práticas que são geradas, também, pelos professores, em nosso caso, pelos professores formadores, ao representar e praticar as normas. Nesta perspectiva, os professores formadores darão "o sentido", a maneira que será desenvolvida esta disciplina.

0 "sentido" atribuído, como já dito, pode ser, burocrático, pois o estágio supervisionado é uma disciplina obrigatória em todos os cursos de licenciatura. Nessa perspectiva é concebido como o produto do processo. Em que os registros de estágio não passam de relatos de práticas desassociados de reflexões.

No entanto, ao se priorizar somente a prática durante as atividades de estágio reforçamos a ideia de que não é necessário saberes específicos para a formação docente, contudo: "deveria fazer emergir as construções dos saberes docentes que refletem as categorias conceituais e práticas dos próprios professores, constituídas no e por meio do seu trabalho no cotidiano". (TARDIF, 2000, p.13, nosso grifo).

Outra forma de conceber os relatórios é entendê-los como um processo formativo que. Nesse sentido, os relatórios não seriam caracterizados como o produto do processo, portanto, seria elemento produção e construção, tendo por finalidade um momento de aprendizagem do futuro professor sobre seu espaço de trabalho. Posto isso, ocorreria uma possível conversação entre uma teoria e a prática. Por conseguinte, o processo avaliativo se daria por meio da formação.

\section{METODOLOGIA DE PESQUISA}

Entendendo os relatórios da disciplina de estágio como um documento do referido curso, para aporte teórico metodológico recorreremos à Análise Documental já que

uma busca de informações em documentos que não receberam nenhum tratamento científico, como relatórios, reportagens de jornais, revistas, cartas, filmes, gravações, entre outras matérias de divulgação. (OLIVEIRA, 2007, p. 69 apud SÁ-SILVA, ALMEIDA; GUINDANI, 2009, p. 6).

Mas além de um documento, serão compreendidos, também, como registros particulares de futuros professores. Logo nos relatórios dos alunos de um curso Licenciatura de matemática, encontramos os seus entendimentos e suas representações sobre a formação e prática docente. Neste curso ocorrem duas disciplinas de estágio voltadas às fases observações e coparticipação (Estágio Fundamental I e Estágio Médio I) e duas destinadas às fases anteriores, mas incluindo a regência (Estágio Fundamental II e Estágio Médio II). Os relatórios que serão tratados neste artigo são da disciplina de Estágio Fundamental II.

No início da análise tínhamos nove relatórios, após a leitura deste material, fizemos o recorte e durante a análise trabalharemos com cinco $^{22}$. Este recorte é justificável à medida que algumas questões se repetiam. É certo que nossa interpretação, a nossa leitura sobre o encontrado e recortado não é neutra, para tecer esta análise partimos de nossas concepções sobre a formação docente e avaliação. E, no decorrer de nossa interpretação tentamos compreender como os alunos utilizam da sua escrita para dar sentido ao observado e praticado durante as atividades de estágio.

\subsection{ANÁLISE: OS RELATÓRIOS CONSTITUÍDOS COMO UM ELEMENTO FORMATIVO E AVALIATIVO PARA A PRÁTICA DOCENTE}

A produção dos relatórios de estágio, neste artigo, é entendida como sendo um momento importante para a formação docente, pois durante os seus registros encontramos, dentre várias questões, as observações do espaço escolar, as práticas, as indagações, os sonhos com a profissão, as decepções, as atitudes e iniciativas. Em outras palavras, encontramos futuros professores entendendo o seu espaço de trabalho. Além disso, nos deparamos com um instrumento importante para o processo avaliativo no exercício de aprender alguns aspectos da docência.

\footnotetext{
${ }^{22}$ Por uma questão de ética, utilizaremos nomes fictícios para os sujeitos envolvidos.
} 
Para esta análise, no que tange à formação na graduação em várias instâncias traremos as contribuições de Ponte (2002), em que categoriza que durante a formação inicial há uma formação pessoal, social e cultural; uma formação científica, tecnológica, técnica ou artística na respectiva especialidade; uma formação no domínio educacional, e por fim, uma de ordem prática.

Sobre a formação pessoal, social e cultural, Ponte destaca que:

A formação nestes campos pode favorecer o desenvolvimento de capacidades de reflexão, autonomia, cooperação e participação, a interiorização de valores deontológicos, as capacidades de percepção de princípios, de relação interpessoal e de abertura às diversas formas da cultura contemporânea, todos eles capacidades e valores essenciais ao exercício da profissão. (PONTE, 2002, p.2)

Nos relatórios encontramos registros que nos possibilitam refletir sobre a relevância desta formação, a futura professora Luisa ao entrevistar a professora regente traz esta questão:

Ela [a professora regente em entrevista a futura professora], a docente salienta que há vantagens em ser professor. Ser professor é um trabalho que envolve diversas habilidades. A carreira de educador pode trazer muitas recompensas: a sua função não é somente transmitir os conteúdos aos alunos, mas ensiná-los a serem pessoas melhores, além de orientá-los, dando todo o apoio que eles precisarem e ao mesmo tempo em que se ensina, há sempre algo novo a aprender, ou seja, o processo de aprendizagem de um educador é contínuo.

Luisa traz em seus registros uma parte da entrevista realizada com a professora regente. Para melhor entendimento do objetivo desta entrevista neste relatório, adicionaremos algumas linhas para explicar a proposta desenvolvida durante o estágio. Na fase de observação e coparticipação é pensado uma pergunta para ser respondida no decorrer do tempo que estarão na escola. Esta pergunta é elaborada de forma individual, ou seja, cada futuro professor fará o seu relatório, tendo como objetivo final conseguir responder a sua pergunta. Desta forma, pensamos o relatório como uma ação investigativa, que a partir da coleta e produção de dados ocorrerá uma breve análise fundamentada teoricamente.

Esta atividade investigativa também contribui para a formação, pois, conforme Maria: "permiti agirmos como pesquisador dentro da Unidade Escolar, pois a partir do que observamos vamos ver o que impede o progresso do processo de ensino/aprendizagem". Ao mencionar o termo "pesquisador" a futura professora encaminha a ideia intrínseca de que para transformar o processo de ensino e aprendizagem em matemática é necessário compreender aquele espaço e, para isto, precisa estar integrado aquele ambiente, ter a pertença, portanto, estar "dentro da unidade escolar". Em outras palavras, é fundamental conviver para apreender o que é uma escola. Corroborando com a ideia de Pimenta (2004, p.114) que a pesquisa na profissão docente " [...] é componente essencial das práticas de estágio apontando novas possibilidades de ensinar e aprender a profissão docente"

No que tange a formação científica, tecnológica, técnica ou artística na respectiva especialidade, Ponte sublinha que: "Sem dominar, com um elevado grau de competência, os conteúdos que é suposto ensinar, o professor não pode exercer de modo adequado a sua função profissional”. (PONTE, 2002, p.2). A este respeito durante os estágios, na maioria das vezes, os futuros professores trazem para as discussões nas aulas de orientação as dificuldades que os alunos da educação básica apresentam em certos conhecimentos matemáticos. Para o futuro professor perceber as dificuldades é necessário saber o conteúdo, para além de "detectar" o problema trazer formas para solucioná-lo. Com este desafio, Vinícius diz que "A maior dificuldade dos discentes foi com as operações com os inteiros, tanto que passei uma semana só com adição e subtração de inteiros." Frente à dificuldade dos alunos do 9o ano o futuro professor inquietou-se com a ausência de conceitos matemáticos fundamentais e buscou uma forma resolver esta situação. Tanto é que em outro momento do seu relatório reforça que

As dificuldades dos alunos não devem ser deixadas de lado em nenhum momento, por isso, sempre que possível, ainda que cuidando para que não atrasasse a programação, retomava os conteúdos mais importantes que percebia não terem sido compreendidos com eficácia.

Em seus escritos é notório o cuidado de Vinícius com as dificuldades dos alunos, tanto que durante a sua prática estas dificuldades são tratadas. Vinícius estava em uma turma do 9o ano, mas trabalhou durante uma semana com conceitos matemáticos destinados aos primeiros anos de escolarização. 
Há indícios que sua prática, em se deter as dificuldades, também esteja consolidada em experiências anteriores, pois atuou no Projeto Mais Educação ${ }^{23}$ e também fazia aulas particulares de matemática. Nestes espaços, na maioria das vezes, os alunos apresentam dificuldades no ensino de matemática. Em virtude disso, supomos que seu tema de pesquisa no estágio que era: "Avaliação do processo de aprendizagem dos alunos com dificuldades matemáticas" esteja relacionado às suas vivências anteriores de professor.

Além de Vinícius, Felipe também tece sobre as dificuldades:

Durante as aulas notei que os alunos têm dificuldade com as quatro operações, algo que preocupa também o professor regente, visto que será necessária a mínima noção de como efetuar cálculos como, por exemplo, divisões que resultam em números decimais, para conteúdos futuros. Neste aspecto Onuchic e Botta (1998) trazem que existem professores que têm buscado dar um novo conceito às noções de matemática básica para que sejam mais compreensíveis as relações que os números e as operações têm com os problemas do mundo, sendo que tais problemas são modelados por esses.

Além da dificuldade apontada por Felipe, também, podemos enfatizar a abordagem metodológica da Resolução de Problemas, assim sendo, diante da dificuldade dos alunos o futuro professor apoiasse em que já aprendeu nas disciplinas do curso de licenciatura voltadas para o estudo da Educação Matemática. Por conseguinte, é necessário saber o conteúdo para "detectar" as dificuldades, mas quando Felipe salienta a relevância de "dar um novo conceito às noções básicas" nas suas entrelinhas aparece a importância metodológica.

Outro ponto importante ao abordar este tipo de formação é o conteúdo a ensinar, Vinícius durante as atividades de estágio participou e organizou uma oficina sobre os números irracionais, registra que:

Durante a atividade, os alunos puderam medir vários objetos circulares, como discos, panelas, e até um pneu de bicicleta. Em seguida, medimos as alturas dos alunos para a segunda parte da atividade. Os alunos se mostraram bastante interessados na oficina, até por ser uma atividade diferente e que eles puderam manipular os objetos e fazer as próprias medições. Os grupos perceberam que ao fazer as medições, chegaram em resultados iguais ou próximos de 3,14 ( $\pi$ ) e $1,61(\Phi)$, e acharam bastante interessante tal resultado, e explicamos que são padrões encontrados na natureza, e demos outros exemplos.

A atividade realizada por Vinícius durante a oficina, diga-se de passagem que ocorreu em um sábado a tarde, favorece a aprendizagem de conceitos considerados difíceis para os alunos, dependendo da forma que os números irracionais é ensinado o conceito fica abstrato, portanto: o que significa o $\pi$ ? Logo, a atividade apresentada permite a resposta desta pergunta. Mais uma vez aparece a importância de saber o conteúdo para conseguir fazer apreendido pelo aluno.

No que diz respeito à formação no domínio educacional, é de fundamental importância: "a reflexão sobre os problemas educacionais do mundo de hoje, as problemáticas e os contributos da investigação realizada pela didáctica e pelas outras áreas das ciências da educação, são, naturalmente, elementos essenciais na constituição da profissionalidade docente" (PONTE, 2002, p.2). Ponte, ao conceituar a formação do domínio educacional, nos sugere refletir sobre a própria profissão, ao trazer a tona o conceito de profissionalidade, sendo "o conjunto de comportamentos, conhecimentos, destrezas, atitudes e valores que constituem a especificidade de ser professor" (SACRISTAN,1995, p. 64). Dentre estes conceitos, durante as atividades de estágios podemos constatar a importância atribuída dos futuros professores à relação entre aluno e professor, sendo percebida como uma relação atitudinal que também propicia uma aprendizagem pensada em se colocar "no lugar do outro", como salienta Luisa:

o docente enfrenta desafios em sala, pois ele não está ali só para mediar o conhecimento e sim de certa forma educar o indivíduo para a vida como no todo, para isso, é necessário que o docente tenha algumas habilidades como saber se colocar no lugar do outro, ter uma boa postura, ter cuidado com as palavras e se dispor a ouvir o que o outro tem a dizer.

Luisa traz em seu depoimento traços da subjetividade que também acompanha a atividade docente. Reforçando esta relevância Lucas destaca: “Quando chegamos na regência „nos deparamos com um

\footnotetext{
23 Programa Mais Educação, criado pela Portaria Interministerial no 17/2007 e regulamentado pelo Decreto 7.083/10.
} 
dilema" que não conseguimos compreender na observação que é a relação aluno-professor em sua forma mais prática e começamos a ver a importância de passar por esse processo para construir nossa identidade de educador". Logo é durante a prática que estas discussões afloram.

Nesta perspectiva, Ponte nos propicia o entendimento das competências de ordemprática:

Não basta ao professor conhecer teorias, perspectivas e resultados de investigação. Tem de ser capaz de construir soluções adequadas para os diversos aspectos da sua acção profissional, o que requer não só a capacidade de mobilização e articulação de conhecimentos teóricos, mas também a capacidade de lidar com situações concretas, competências que se têm de desenvolver progressivamente ao longo da sua formação. (PONTE, 2002, p.2)

Na maioria das vezes é na disciplina de Estágio que os futuros professores se "percebem como professores". Em outras palavras, é durante as atividades de estágio que deixam o "lugar de alunos de um curso de licenciatura" para ocupar outro espaço "professores de matemática". O momento de vivenciar e praticar. Desta forma, Lucas recorda:

a regência faz o nosso mundo de "faz de conta", que muitas vezes é idealizado nas aulas dentro daquelas quatro paredes, em que nos é apresentado inúmeras formas de desenvolver aulas dinâmicas se esquecendo que trabalhamos e somos seres imprevisíveis, "vir abaixo". Quando temos que lidar com uma turma na qual você pensa uma metodologia e ela não pode ser desenvolvida, pois os alunos não estão familiarizados ou não construíram uma base consolidada.

A crítica de Lucas explana algo já muito discutido em pesquisas voltadas à formação inicial do professor, a desarticulação entre as disciplinas voltadas á formação e a realidade encontrada nas escolas. Ao se referir que "o mundo de faz de contas, vem abaixo" mostra a desarticulação entre a escola e o curso. Em contrapartida, também poderíamos refletir por outro prisma, cada sala de aula é singular no sentido de ser única, portanto, por mais que se discuta sobre as abordagens metodológicas é o professor que direciona a melhor forma de ensinar aquele conteúdo para aquela turma. Corroboramos com Morgado: "Parece não suscitar controvérsia a ideia de que ser professor, hoje, é mais do que executar um conjunto de procedimentos e rituais precisos e preestabelecidos" (2004, p.349). Aliás, também, constituindo um elemento formativo na apropriação da autonomia de seu trabalho.

Outra situação que a prática oportuniza é perceber a comunidade escolar e suas diversidades, garantido o entendimento de questões sociais. Lucas relata sobre a "Outra realidade que é vivenciada é a das drogas e consequentemente das facções, assunto que eles [alunos] falam abertamente sem nenhum receio, ou seja, esta realidade faz parte do contexto escolar." Lucas destaca esta "outra realidade", no entanto, não é "outra", mas a "realidade", a escola está inserida em um contexto cultural, mas, também, social, em que os valores sociais também são compartilhados e transmitidos (neste caso, de colega para colega).

Também é função da prática fazer com que o futuro professor se entenda como professor, se percebendo envolvido não só com conteúdos e metodologias. A atividade docente vai muito além, pois trata questões subjetivas, por exemplo, Vinícius traz:

Apesar de em alguns momentos ter ficado estressado por comportamentos, ou triste por notas, às vezes até com vontade de desistir, foi um estágio muito gratificante para minha experiência pessoal e profissional, de forma que me ajudou a "perder o medo" de entrar numa sala para dar aula, e a criar metodologias para meu avanço profissional.

Neste momento de sua escrita Vinícius traz à tona muitos traços da subjetividade que acompanham o trabalho docente o stress em função da indisciplina, a tristeza por não ter conseguido atingir seu objetivo, a vontade de desistir por se sentir incapaz e a resistência por acreditar. Mas, o mais significativo na escrita de Vinícius é ver que este momento de estágio foi praticado e refletido, levando em consideração a sua "experiência pessoal e profissional". 


\section{CONSIDERAÇÕES FINAIS}

No decorrer da análise podemos considerar a importância dos registros dos relatórios para a formação docente, pois desvenda além de práticas, atitudes, desafios e anseios. Os relatórios constituídos com esse caráter poderão possibilitar ao futuro professor um momento de reconhecimento de seu espaço profissional, sendo uma das formas de ter pertença de sua profissão.

\section{REFERÊNCIAS}

[1] Julia, Dominique. A cultura escolar como objeto histórico. Revista Brasileira de História da Educação. Campinas: Autores Associados, SBHE, n. 1, p. 9-43, jan./jun. 2001.

[2] Pimenta, Selma Garrido. (org.). 0 estágio e a docência. São Paulo: Cortez, 2004.

[3] Ponte, João Pedro (2002). A vertente profissional da formação inicial de professores de matemática. Educação Matemática em Revista. Brasília: SBEM, p. 3-8, 2002.

[4] Tardif, Maurice. Saberes Profissionais dos Professores e Conhecimentos Universitários: elementos para uma epistemologia da prática profissional dos professores e suas consequências em relação à formação para o magistério. Revista Brasileira de Educação. ANPED, São Paulo, n. 13, p. 5-24, jan./abr. 2000.

[5] Morgado, José Carlos Avaliação e Qualidade do Desenvolvimento Profissional Docente: que relação? Avaliação, Campinas; Sorocaba, SP, v. 19, n. 2, p. 345-361, jul. 2014.

[6] Rocha, Cristiane; Christo Gobbi, Beatriz; Simão, Ana. O Uso da Análise de Conteúdo como Ferramenta para a Pesquisa Qualitativa: descrição e aplicação do método. Organizações Rurais Agroindustriais, 2005.

[7] Sá-Silva, Jackson Ronie; Almeida, Cristóvão Domingos, Guindani, Joel Felipe. Pesquisa documental: pistas teóricas e metodológicas. Rev. Bras. de História \& Ciências Sociais. n. I, p. 1-15, jul., 2009.

[8] Sacristán, Gimeno. Consciência e acção sobre a prática como libertação profissional dos professores. In: Nóvoa, António. (org.) Profissão Professor. Lisboa: Porto Editora, 1999. 


\section{Capítulo 21}

O que dizem as narrativas sobre a identidade do professor que ensina Matemática no Ensino Fundamental?

\section{Dayse do Prado Barros}

Marcus Vinícius Pereira

Resumo: o presente artigo procura pensar a identidade docente daqueles que ensinam Matemática no Ensino Fundamental. Para ancorar esse processo investigativo nos apoiamos na pesquisa narrativa, por ser uma metodologia que busca compreender a experiência humana. Partimos de uma reflexão sobre o letramento matemático, que definimos como a capacidade dos estudantes de analisar, raciocinar e refletir ativamente sobre seus conhecimentos e experiências, enfocando competências que serão relevantes para suas vidas futuras, na solução de problemas do dia-a-dia. Avançamos para uma análise do documento que registra as orientações curriculares para o Ensino Fundamental no Distrito Federal, cujo nome é Currículo em Movimento do Distrito Federal para, só a partir daí, debater quem é o professor que ensina Matemática no Ensino Fundamental. Finalmente, passamos a entrever possibilidades dentro da Educação Matemática.

Palavras-chave: Letramento matemático; Identidade docente; Educação Matemática 


\section{TECENDO OS CONCEITOS INICIAIS}

Esse artigo decorre de nossa experiência docente de mais de 25 anos na Educação Básica, mais especificamente relacionadas ao ensino de Matemática desde os anos iniciais do Ensino Fundamental, passando pelos Anos Finais e também o Ensino Médio. Além da atuação como docentes, também vivenciamos experiências como gestores e/ou coordenadores pedagógicos no âmbito da Secretaria de Educação do Distrito Federal. Neste trabalho nosso foco de análise visa compreender os motivos que levam as crianças, seres matemáticos por natureza (curiosos e investigativos), a perderem paulatinamente o interesse por essa disciplina. Esse desinteresse parece crescer a cada ano de escolarização até que, por fim, a Matemática se torna a disciplina ora odiada, ora temida, porém dificilmente aprendida.

A primeira situação que queremos esclarecer diz respeito à ideia de letramento matemático. Há uma confusão conceitual em torno dessa expressão. Ao se falar de alfabetização, muitos evocam a ideia de decodificação, compreensão e expressão na língua materna. Obviamente, no contexto em tela, estamos expandindo esse sentido stricto para outro mais amplo.

[...] a compreensão dos textos que lemos e a eficiência dos textos que escrevemos dependem também dos conhecimentos que vamos desenvolvendo sobre os processos, os recursos, as representações e os critérios adotados para quantificar e operar com quantidades, para medir e ordenar, para orientar-se no espaço e organizá-lo, para apreciar, classificar, combinar e utilizar as formas. Isso porque os textos refletem o jeito como aqueles que o escrevem se relacionam com o mundo e esse jeito é decisivamente marcado por esses processos, recursos, representações e critérios que se relacionam ao que chamamos de "matemática" (BRASIL, 2014, p. 29).

Portanto, extrapolando a ideia de letramento para um sentido lato, adotamos como eixo norteador a definição de letramento matemático utilizada pela Organização de Cooperação e Desenvolvimento Econômico:

La competencia matemática implica la capacidad de un individuo de identificar y entender el papel que las matemáticas tienen en el mundo, para hacer juicios bien fundamentados y poder usar e involucrarse con las matemáticas. El concepto general de competencia matemática se refiere a la capacidad del alumno para razonar, analizar y comunicar operaciones matemáticas. Es, por lo tanto, un concepto que excede al mero conocimiento de la terminología y las operaciones matemáticas, e implica la capacidad de utilizar el razonamiento matemático en la solución de problemas de la vida cotidiana (OCDE, 2015, p. 12).

Dito de outra forma, o letramento matemático pode ser entendido como a capacidade dos estudantes de analisar, raciocinar e refletir ativamente sobre seus conhecimentos e experiências, enfocando competências que serão relevantes para suas vidas futuras, na solução de problemas do dia-a-dia.

Em Matemática, o nível 2 do PISA ${ }^{24}$ - Programme for International Student Assessment-, que é uma avaliação trienal comparada, aplicada a estudantes na faixa dos 15 anos (idade em que se pressupõe o término da escolaridade básica obrigatória na maioria dos países), é o patamar que a OCDE estabelece como o mínimo necessário para que os jovens possam exercer plenamente sua cidadania. Nesse nível os estudantes são capazes de interpretar e reconhecer situações em contextos que não exigem mais do que uma inferência direta. São capazes de extrair informações relevantes de uma única fonte e de utilizar um modo simples de representação. Os estudantes situados neste nível conseguem empregar algoritmos, fórmulas, procedimentos ou convenções básicas para resolver problemas que envolvem números inteiros. São capazes de fazer interpretações literais dos resultados. Os resultados apresentados pelo PISA 2015 nos dão conta de que cerca de $70 \%$ dos estudantes do nosso país estão abaixo do nível 2, conforme o gráfico abaixo:

\footnotetext{
${ }^{24} \mathrm{O}$ objetivo do Pisa é produzir indicadores que contribuam para a discussão da qualidade da educação nos países participantes, de modo a subsidiar políticas de melhoria do ensino básico. A avaliação procura verificar até que ponto as escolas de cada país participante estão preparando seus jovens para exercer o papel de cidadãos na sociedade contemporânea.
} 
Figura 1: Percentual de estudantes por nível de proficiência e unidade da Federação, matemática - PISA

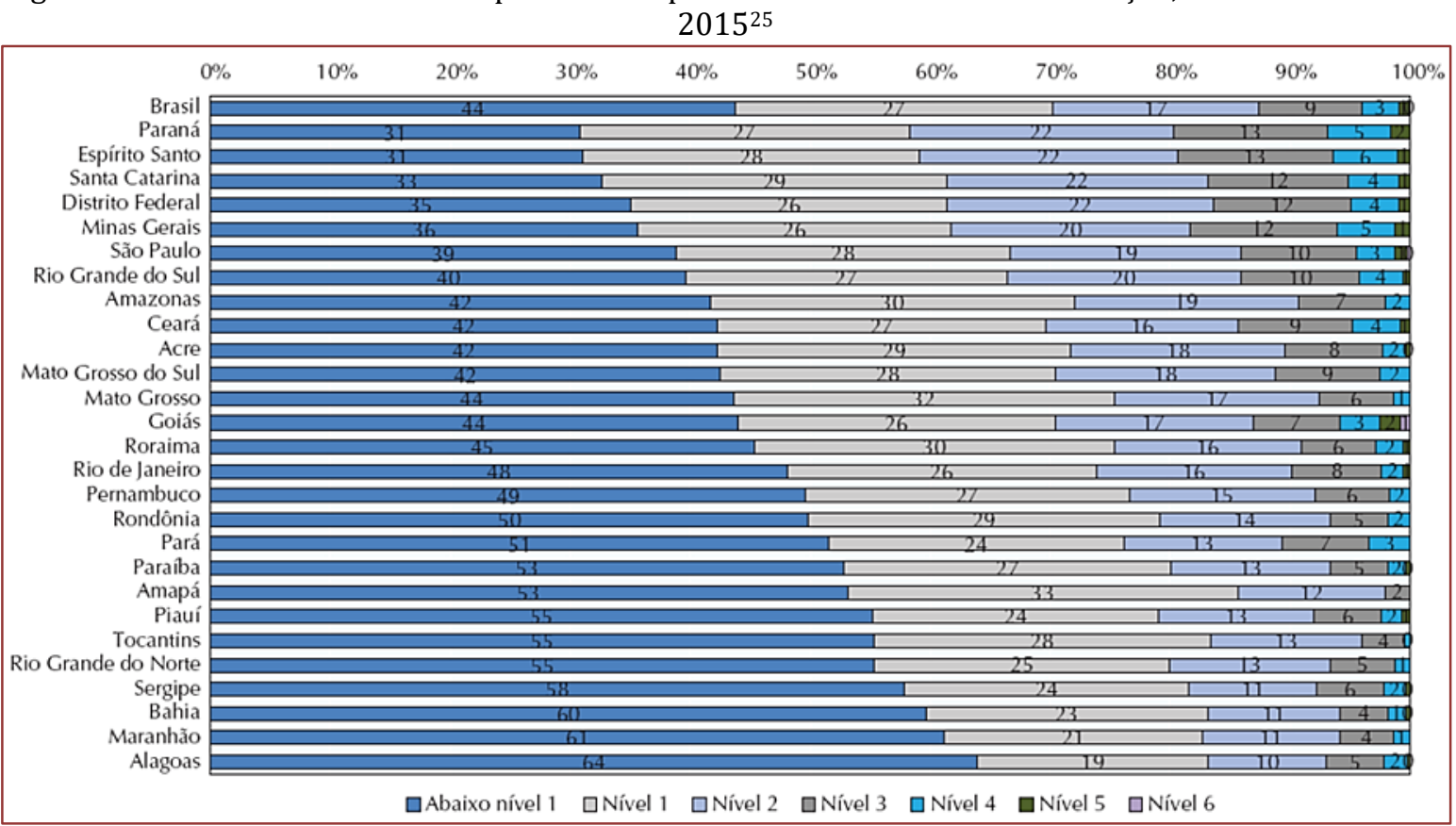

Fonte: OCDE, Inep

Conforme dissemos anteriormente, a nossa experiência docente nos levou a perceber que a cada ano de escolarização os estudantes, em geral, perdem o interesse pela matemática. Essa observação empírica parece ser constatada pelos resultados do PISA, por exemplo ou de outros instrumentos de avaliação de larga escala.

\section{ANALISANDO A MATEMÁTICA NOS ANOS INICIAIS DO ENSINO FUNDAMENTAL}

Nos propusemos analisarar o documento que registra as orientações curriculares para o Ensino Fundamental no Distrito Federal, cujo nome é Currículo em Movimento. Inclusive, muito recentemente a Secretaria de Educação revisitou o currículo do Ensino Fundamental e da Educação Infantil para se atender as demandas da homologação da BNCC - Base Nacional Curricular Comum, que se deu em dezembro de 2017. Neste sentido, importa esclarecer que a 1a edição do Currículo em Movimento se deu em 2014 e a 2 $2^{\text {a }}$ edição, já com as adequações para se atender a BNCC, aconteceu em dezembro de 2018. Tanto a $1^{\underline{a}}$ quanto a $2^{\underline{a}}$ edição, trazem em seu escopo o currículo integrado e como eixos integradores para os anos iniciais ( $1^{\mathrm{o}}$ ao $5^{\mathrm{o}}$ ano) temos a alfabetização, os letramentos e a ludicidade. Já para os anos finais (6ำ ao 9a ano) são dois os eixos: a ludicidade e os letramentos.

Foi possível identificar que a articulação interdisciplinar dos componentes curriculares é um aspecto importante dentro da proposta do Currículo em Movimento. Para além disso, a ludicidade recebe um destaque importante ao ser considerada um eixo integrador para toda a etapa do Ensino Fundamental. Nesse sentido Muniz (2008) assegurou que só aprende quem brinca, só brinca quem não tem medo de errar. Quem não tem medo de errar, faz matemática. Ou seja, a aprendizagem lúdica, contextualizada, interdisciplinar e prazerosa deveria ser valorizada nos nove anos dessa etapa da Educação Básica:

Na vida, uma das funções da matemática é a de tornar o indivíduo capaz de resolver problemas cada vez mais complexos. Assim, o ensino da Matemática deve reforçar esse propósito. Para ensinar Matemática, o professor precisa favorecer a problematização, trazer situações que provoquem os estudantes, que os façam pensar, buscar soluções próprias e socializá-las. É necessário abrir espaços para que a cultura social invada espaços da sala de aula, a fim de que a

\footnotetext{
${ }^{25}$ Em 2018 houve uma nova versão do PISA, no entanto, estima-se que seus resultados só sejam de conhecimento público no terceiro quadrimestre do ano de 2019.
} 
Matemática se torne significativa e pulsante (DISTRITO FEDERAL, 2018, p. 154).

Ao refletirmos sobre a orientação do Currículo em Movimento a respeito da necessidade de que o professor favoreça "a problematização, [traga] situações que provoquem os estudantes, que os façam pensar, buscar soluções próprias e socializá-las", nos levou a pensar a respeito de quem é o professor que ensina matemática nos anos iniciais e, principalmente, se ele se sente capaz de tornar a Matemática "significativa e pulsante" para seus estudantes. Por sua vez, essa pergunta nos levou ainda a uma outra: quem é o professor que ensina matemática nos anos finais do ensino fundamental?

\section{QUEM É O PROFESSOR QUE ENSINA MAEMÁTICA NOS ANOS INICIAIS?}

A narrativa colhida em uma roda de conversa com uma equipe de professoras dos anos iniciais de uma escola pública do Distrito Federal nos permitiu entrever, em partes, a identidade docente do professor (na verdade, a maioria é professora) que ensina Matemática para as crianças nos primeiros anos de escolarização.

Aceitaram participar dessa pesquisa 15 professoras com idades entre 25 e 45 anos de idade. Todas pedagogas e professoras efetivas da Secretaria de Educação do Distrito Federal. 0 tempo de magistério variou entre 4 a 25 anos dedicados ao trabalho docente. As perguntas foram: porque você escolheu a carreira do magistério? Qual a sua relação com a Matemática durante o seu processo de formação na Educação Básica? Como é ensinar Matemática para seus alunos?

As respostas à primeira pergunta giraram basicamente em torno de três eixos centrais: as professoras mais experientes, com maior tempo de magistério afirmaram, em sua maioria, que esse era o sonho desde de menina e que nas brincadeiras da infância sempre brincavam de "escolinha e que adoram atuar como professoras". Outro grupo afirmou que a escolha se deu porque sabiam que não ficariam sem emprego, seriam absorvidas pelo mercado de trabalho. Um terceiro grupo afirmou que a escolha se deu em função de que o curso de Pedagogia era a segunda ou terceira opção e, como não conseguiram passar no vestibular para a primeira opção, acabaram fazendo Pedagogia.

Já as respostas à pergunta: Qual a sua relação com a Matemática durante o seu processo de formação na Educação Básica? foram surpreendentes. Das 15 professoras apenas 3 afirmaram que não tiveram dificuldades com esse campo do saber durante sua formação básica. As outras 12, todas narraram episódios que descreviam uma relação tensa com a disciplina, às vezes até traumática. Alguns relatos (seis para ser mais exata), descreviam a difícil relação com os professores de matemática que eram considerados severos, rígidos e distantes. Para algumas professoras, ter essa reminiscência foi um exercício difícil. Uma afirmou: "acho que por isso nunca consegui aprender matemática. Ele (seu antigo professor) representava tudo o que eu não queria ser".

Já as respostas à última pergunta, qual seja: Como é ensinar Matemática para seus alunos? foram as mais reveladoras e que permitiram trazer à tona percepções e sentimentos que não estavam muito claros sequer para cada uma das participantes. As respostas variaram muito quanto à forma de serem ditas, mas, em geral, elas poderiam ser resumidas em dois campos semânticos: medo e antipatia. Queremos destacar que medo, segundo o Dicionário Online de Português é: "grande inquietação em relação a alguma situação desagradável ou a possibilidade de um insucesso". Já antipatia na definição do mesmo dicionário é: repugnância instintiva diante de alguém ou de alguma coisa; aversão, repulsa".

As narrativas vão desde: " ah... em 20 anos de profissão eu nunca peguei os 4 o ou $5^{\circ}$ anos. Como eu vou ensinar fração? Número decimal? Transformação das medidas de grandeza? Gente, eu nunca aprendi isso muito bem! " Até pequenas confissões: " então, eu gosto da área de ciências sociais, então as minhas aulas nesse campo do saber são maravilhosas, fazemos projetos, aulas de campo e aí não sobra muito tempo para as aulas de Matemática. Apenas cinco professoras disseram que ensinam Matemática sem receio. No entanto, dentro essas cinco, três disseram que cumprem o currículo, mas não se sentem aptas a darem aulas lúdicas, com jogos e aplicações práticas. Nenhuma professora, dentre as 15 presentes, disse conseguir correlacionar todos os conteúdos da Matemática do anos iniciais com o cotidiano: 'Ah, sistema monetário, por exemplo, a gente consegue. Mas há conteúdos mais difíceis, né?"

É importante salientar que o aspecto lúdico está presente no Bloco Inicial de Alfabetização (BIA), bloco que abarca os três primeiros anos de escolarização do estudante, ou seja, crianças de 6, 7 e 8 anos de idade). A partir daí, quando a criança ingressa no 4 o ano do Ensino Fundamental, as vivências lúdicas vão se escasseando. A aprendizagem que antes costumava acontecer dentro de uma proposta interdisciplinar 
vai ficando cada vez mais fragmentada. Não raro, o 5o ano se torna um preâmbulo para o ingresso nos anos finais do Ensino Fundamental. A tônica básica passa a ser que o estudante necessita se preparar para o tão temido 6ำ ano. Cenas dantescas são pintadas, o lúdico não tem mais espaço, afinal, lá tudo é muito corrido, tudo é muito sério, você não pode errar, você precisa aprender a se virar sozinho porque no $6^{0}$ ano tudo é muito "cruel".

Para Santomé (1998) disciplina é uma maneira de organizar e delimitar um trabalho dentro de um ponto de vista particularizado, decorrendo daí que cada disciplina oferece uma imagem particular da realidade. Essa forma de organização dos currículos não é neutra e apresenta intencionalidades claras de reproduzir o processo de especialização e divisão do processo de produção da sociedade capitalista e, por assim o ser, exclui dimensões inerentes ao ser humano como a imaginação, a criatividade, a intuição e a incerteza. A proposta interdisciplinar trazida pelo autor traz em seu escopo uma vontade e um compromisso de elaborar um contexto mais geral e por isso mesmo tem um grande poder estruturador pois o conhecimento encontra-se organizado em eixos mais globais nos quais as disciplinas passam a depender umas das outras. Nessa perspectiva, a matemática, por exemplo serviria para que os estudantes aprendam a medir e quantificar as injustiças sociais suportadas por milhões de pessoas, mobilizando assim refletir ativamente sobre seus conhecimentos e experiências, enfocando competências que serão relevantes para suas vidas futuras, na solução de problemas do dia-a-dia. Santomé (1998, p.73 e 74) defende que, à medida que se organiza estruturas conceituais compartilhadas por várias disciplinas, fica mais fácil realizar transferências das aprendizagens assim adquiridas para outros contextos disciplinares mais tradicionais. Alunos e alunas com educação mais interdisciplinar estão mais capacitados para enfrentar problemas que transcendem os limites de uma disciplina concreta e para detectar, analisar e solucionar problemas novos. A motivação para aprender é muito grande, pois qualquer situação ou problema que interessar o estudante poderá transformar-se em objeto de estudo.

Obviamente, a prática docente é construída e se estabelece na prática. "Ninguém começa a ser educador numa certa terça-feira às quatro horas da tarde. Ninguém nasce educador ou marcado para ser educador. A gente se faz educador, na prática e na reflexão sobre a prática". (FREIRE, 1991, p. 58). Essas narrativas expõem uma realidade com a qual nós precisamos refletir - será que a prática do ensino da Matemática nos anos iniciais capaz de proporciona experiências que tornem os estudantes capazes de analisar, raciocinar e para a cidadania e para a criação de estratégias para a solução desses problemas.

\section{CHEGANDO AO 6을 ANO: APAGARAM TUDO, PINTARAM TUDO DE CINZA}

A chegada ao 6ํao ano é, no Brasil, um momento de rupturas. Em geral, até o 5o ano do Ensino Fundamental o estudante tinha apenas uma professora. A partir daqui ele terá cerca de oito professores, para oito disciplinas diferentes que não conversam entre si. Ficará para trás uma escola mais ou menos acolhedora. Estarão diante de um mundo novo: aulas de 50 minutos, professores que não terão tempo de conhecer seus alunos e conteúdos intermináveis que precisam ser vencidos. Especificamente no caso do ensino da Matemática, os professores ainda não conseguem responder a questão fundamental que fazem os alunos: "mas professor(a), porque precisamos aprender isso?" Em grande medida isso ocorre porque "as disciplinas ou matérias singulares são narcisistas, orientadas para seu próprio desenvolvimento mais do que para aplicação fora de si mesmas" (BERNSTEIN, 1993, p.160).

Nessa perspectiva, o estudante não é estimulado a pensar, a tentar, a construir o conhecimento com a mediação de outros colegas. Afinal, é absolutamente necessário otimizar o tempo para dar conta de vencer o conteúdo. Levar em consideração o valor pedagógico do erro é um 'luxo para o qual não é possível destinar tempo'. A partir de agora o erro será considerado algo abominável. Aqui nos anos finais do Ensino Fundamental ninguém mais parece lembrar que quem não tem medo de errar, faz matemática (MUNIZ, 2008).

Organizamos uma reunião com seis professores de Matemática para a realização de uma roda de conversas e selecionamos duas perguntas: 1) durante sua graduação, as disciplinas pedagógicas cursadas te prepararam para a realidade da prática docente? 2) você diria que conhece bem o processo de construção do conhecimento humano? A resposta à primeira pergunta foi unânime: não. As variações dentro desse contexto surgiram quando indagados porquê respondiam assim. Três professores responderam que na época da graduação as disciplinas próprias da Licenciatura eram culturalmente vistas como secundárias, de forma que a opção era estudar as disciplinas relacionadas à Matemática e preterir as primeiras. Dois professores disseram que as disciplinas foram tão superficiais, tão teóricas e desconectadas da realidade que não pareciam úteis, assemelhando-se mais a uma questão de gravar nomes de teóricos e datas. Um professor não soube responder. 
A segunda pergunta teve apenas duas respostas sim e quatro respostas não. Os professores que responderam sim, afirmaram que conhecem pois buscaram esse conhecimento por meio da formação continuada e de leituras. Afirmaram ainda que esse conhecimento foi fundamental para mudar suas perspectivas e que a partir daí conseguiram ressignificar seu papel como educador matemático. 0 grupo de professores que responderam não se subdividiu em dois grupos: dois professores afirmaram que apesar de desconhecerem a teoria dos processos de construção do conhecimento, aprenderam na prática quais metodologias são mais assertivas. 0 outro subgrupo afirmou que nunca havia pensando sobre a questão. As narrativas dos professores do Ensino Fundamental - Anos Finais convergiram ao concordar que essa é a etapa mais difícil de atuação.

As narrativas dos professores de Matemática também nos levam a questionar a formação inicial desses profissionais. Em um cenário sociopolítico cada vez mais complexo, o professor necessita assumir para si que seu papel de educador matemático encontra-se para além de apenas ter o conhecimento desse campo do saber. Evidentemente esse conhecimento técnico é condição sine qua non para se ensinar Matemática. Imprescindível, porém não suficiente.

Outra importante disfunção do sistema é o fato de que, em geral, os professores que assumem as turmas de 6ㅇ ano estão absolutamente despreparados ou descontentes com esta a tarefa. A organização administrativa para a distribuição de carga horária dos professores do Distrito Federal determina, em linhas gerais, que os professores mais antigos escolham suas turmas. É facilmente observável que à medida que os professores vão fazendo suas escolhas, os 6으on "sobram" para os que têm menos tempo de atuação no magistério público, pouco importando que estes profissionais tenham afinidade ou preparo para a hercúlea tarefa. Estes, ao assumirem essas turmas não raro sentem-se aborrecidos com a imaturidade das crianças recém-admitidas nos anos finais. Também desconhecem o processo de construção do conhecimento, desconhecem a importância que a aprendizagem colaborativa representa para essa faixa etária. Muitas vezes tratam esses estudantes como se fossem adultos em miniaturas. Esquecem-se que, segundo Piaget (2012), esses sujeitos encontram-se no estágio Operatório Concreto (7 11 anos de idade) cuja principal característica é que o pensamento da criança ainda é de natureza concreta. Ainda assim, aprendizagem lúdica, prazerosa, é desconsiderada. Nesse contexto fragmentado e pouco adaptado às condições psicobiológicas dos estudantes dessa etapa do Ensino fundamental, e com professores sobrecarregados, acaba por refletir uma concepção mecanicista da aprendizagem. Meninos e meninas seguem recebendo, inertes, conteúdos prontos e, quase que hermeticamente embalados. A escola segue esquecendo que "a inteligência não pode ser desenvolvida sem material sobre o qual pensar" (DUCKWORTH, 1981, p. 340).

Não é difícil deduzir que a soma de todos esses fatores tende a convergir para o insucesso. Importa dizer que de fracasso em fracasso o estudante vai perdendo a confiança em sua própria capacidade de aprender. A escola se torna chata e a Matemática torna-se uma disciplina temida. Santomé (1988, p. 107) analisando o grande peso culturalmente imposto à essa disciplina afirmou que "o resultado [desse processo] é uma espécie de sacralização ou idolatria do saber, porque ele não é compreendido e sua utilidade e funcionalidade não são captadas". Cabe-nos aqui destacar que, uma vez estabelecida essa barreira, dificilmente ela será superada no decorrer dos outros anos de escolarização da educação básica. Em consequência disso, a maioria de nossos alunos não atingem um adequado nível de letramento matemático, muitas vezes chegando ao Ensino Médio sem ter adquirido conhecimentos básicos como: operação com frações, ou dificuldades em interpretar problemas.

Como dito anteriormente, o documento que registra as orientações curriculares para o Ensino Fundamental no Distrito Federal é o Currículo em Movimento, que preconiza o currículo integrado e tem como eixos integradores para os anos finais a ludicidade e os letramentos:

Uma das alternativas metodológicas possíveis para que a aprendizagem matemática se realize de modo lúdico, reflexivo e crítico é a utilização de situações problema. A resolução de situações-problema que fazem parte do contexto da vida dos estudantes corrobora sobremaneira para a construção permanente de conceitos e para o desenvolvimento de procedimentos próprios. $\mathrm{Na}$ resolução de situações problema, deve-se buscar a socialização de diferentes processos utilizados pelos estudantes num contexto de partilha e construção conjunta do saber. (DISTRITO FEDERAL, 2018, p. 154).

Uma outra orientação do Currículo em Movimento é:

Recomenda-se que as atividades lúdicas sejam inseridas em todos os anos/blocos, estimulando as capacidades e interesses dos estudantes para que 
sejam desafiados cognitivamente e desenvolvam as habilidades de cooperação, socialização, autonomia, comunicação, inclusão, respeito à diversidade de opiniões, argumentação estruturada, dentre outras. (DISTRITO FEDERAL, 2018, p. 156).

No entanto, essa articulação orientada pelo currículo oficial não consegue ser transposta para a realidade. 0 professor sente-se pressionado a cumprir uma lista de conteúdos extensa. E essa lista torna-se, muitas vezes, a prioridade do professor. Dessa forma, a proposta de realização de atividades lúdicas, ainda que estas sejam capazes de desafiar o estudante cognitivamente e estimular sua capacidade e interesse, são vistas como atividades que vão tomar tempo e atrapalhar a aplicação dos conteúdos. De fato, à partir do 6ำ ano, o colorido e a alegria dos anos iniciais vão cedendo espaço a uma visão cinza da realidade escolar.

De tal modo, podemos supor que o currículo prescrito no documento oficial não é o mesmo vivenciado nas escolas de Ensino Fundamental. Para discutir essa questão recorremos à Sacristán (2000) no sentido de elucidar o que é o currículo prescrito:

O currículo prescrito para o sistema educativo e para os professores, mais evidentemente no ensino obrigatório, é a sua própria definição, de seus currículos e demais orientações relativas aos códigos que o organizam, que obedece às determinações que procedem do fato de ser um objeto regulado por instâncias políticas e administrativas. Sacristán (2000, p. 109).

Nesse ponto fomos levados a pensar sobre o conceito de currículo oculto. Pois se o currículo prescrito não é o mesmo vivenciado nas escolas, certamente, outro currículo o é. 0 currículo oculto, para Silva expressa uma operação fundamental da análise sociológica com os processos que estão ocultos na compreensão comum que temos da vida cotidiana, estando por isso mesmo conectado com processos sociais amplos. 0 autor definiu currículo oculto como sendo:

Constituído por todos aqueles aspectos do ambiente escolar que, sem fazer parte do currículo oficial, explícito, contribuem de forma implícita para aprendizagens sociais relevantes. [...] Em outras palavras, precisamos saber "o que" se aprende no currículo oculto e através de quais "meios". Para a perspectiva crítica, o que se aprende no currículo oculto são fundamentalmente atitudes, comportamentos, valores e orientações que permitem que crianças e jovens se ajustem da forma mais conveniente às estruturas e às pautas de funcionamento, consideradas injustas e antidemocráticas e, portanto, indesejáveis, da sociedade capitalista. Entre outras coisas, o currículo oculto ensina, em geral, o conformismo, a obediência, o individualismo. (SILVA, 2016, p. 78).

Portanto, partindo da Teoria Crítica como fio condutor para a análise da dinâmica estabelecida nas escolas, podemos assumir que essa organização fragmentada, mecanicista, que cerceia a imaginação, a interação, a colaboração e a solidariedade, estimulando o conformismo, o individualismo e a aceitação de que os processos sociais são prontos e acabados, não existem na escola sem intencionalidades. Não são dinâmicas neutras. Não são apenas consequências naturais e inevitáveis. Ao contrário, apresentam claramente as intenções das classes dominantes de manterem seu poder. Marcadamente neste momento histórico que estamos inseridos, mergulhados nesse clima em que só é importante aquilo que favorece o mercado e a produção, com uma verdadeira avalanche das políticas neoliberais, com sua ideologia de competição baseada no mérito e a consequente naturalização do fracasso e a responsabilização do indivíduo que impregna toda a organização, legitimando uma visão reacionária da patologia social. (Santomé, 1998).

\section{CONSIDERAÇÕES FINAIS: ENTREVENDO POSSIBILIDADES}

Certamente, a adoção de uma perspectiva mais integrada e interdisciplinar do currículo seria uma alternativa para tornar a Educação Matemática contextualizada, interdisciplinar e prazerosa, capaz de promover a aprendizagem lúdica. Para Ciavatta e Ramos (2011) precisamos superar a mentalidade conservadora dos padrões pedagógicos vigentes. Nesse sentido Santomé (1998, p. 29) afirma que " um corpo docente que pesquise e trabalhe em equipe é algo consubstancial a este modelo de currículo". Portanto, não é sem mudanças de postura, sem a perda de nosso individualismo narcisista que poderemos avançar. 
Nesse contexto, a palavra chave parece ser ressignificar. Há a necessidade de lançar um novo olhar para a real situação, para aquilo que de fato acontece quando o professor entra na sala de aula e fecha a sua porta. As professoras dos anos iniciais não se reconhecem como educadoras matemáticas, pois sua formação inicial lhe proporcionou pouco contato com a Matemática - geralmente apenas uma única disciplina de $60 \mathrm{~h}$-, insuficientes para proporcionarem sólidas vivências nesse campo do conhecimento. Por outro lado, os educadores matemáticos dos anos finais, se reconhecem muito mais como matemáticos do que propriamente como educadores. Sua formação inicial não proporcionou a esses profissionais uma vivência sólida na sua formação pedagógica.

Como ressignificar? Uma resposta bem imediata traria para o foco a questão da formação de professores, a mudança dos currículos dos cursos de licenciatura e de Pedagogia. De fato, concordamos que essa mudança é necessária. Mas a grande questão é: o que mudar? Esse questionamento parece apontar para o fato de que o campo da Educação Matemática está para além da Pedagogia e para além da própria Matemática, constituindo-se assim, um novo campo do conhecimento onde as duas ciências se interpenetram estabelecendo intersecções e novas relações com o saber. Para além do estabelecimento de novas relações com o saber, vislumbrar novas relações entre pedagogos e matemáticos. Campos do conhecimento antes considerados distantes, quase que diametralmente opostos necessitam de aproximação.

Ao trabalhar com este modelo integrador, professores se aperfeiçoarão como profissionais reflexivos e críticos, convertidos em pesquisadores em sua sala de aula, aprenderão a agir de um modo mais reflexivo e eficaz e a realizar em todos os momentos um exame das implicações morais e políticas das propostas de trabalho que oferecerem e incentivarem. Os grupos docentes que trabalham desta maneira podem enfrentar melhor os desafios de uma educação libertadora (SANTOMÉ 2011, p. 254).

Certamente essas mudanças conceituais propõem uma ruptura com o modelo tradicional e por isso exigem estudo e qualificação conceitual e prática dos professores, com envolvimento do quadro docente permanente para proporcionar a todos os professores formação continuada, condições materiais (instalações, laboratórios etc.) e condições dignas de trabalho, salariais, de carreira e de compromisso com as instituições. (CIAVATTA; RAMOS, 2011 Outro aspecto que observamos é o quanto nosso sistema educativo é burocrático e que em virtude dessa característica, os docentes são abandonados à própria sorte e sobrecarregados com tarefas outras para além daquelas que sejam eminentemente pedagógicas). Obviamente, sem garantias de condições mínimas de trabalho, estamos fadados à precarização do trabalho docente. Aliás, esse processo está bem marcado no Brasil desde os anos 1990 com a introdução de políticas neoliberais no país.

\section{REFERÊNCIAS}

[1] Brasil. Secretaria de Educação Básica. Apresentação: Pacto Nacional pela Alfabetização na Idade Certa. Brasília: Ministério da Educação, 2012.

[2] Brasil. Instituto Nacional de Estudos e Pesquisas Educacionais Anísio Teixeira. Brasil no Pisa 2015 - Análises e reflexões sobre o desempenho dos estudantes brasileiros. Disponível em http://download.inep.gov.br/acoes_internacionais/pisa/resultados/2015/pisa2015_compl_eto_final_baixa.pdf>. Acesso em 20 de março de 2019

[3] Bernstein, Basil. La estrutura del discurso pedagógico. Clases, códigos y control. Vol. 4. Mardi. Morata Fundación Paideia, 1993.

[4] Ciavatta, Maria; Ramos, Marise. Ensino médio e educação profissional no Brasil dualidade e fragmentação. Revista Retratos da Escola, Brasília, v. 5, n. 8, p. 27-41, jan./jun. 2011.

[5] Distrito Federal. Secretaria do Estado de Educação. Currículo em Movimento do Distrito Federal: Ensino Fundamental - Anos iniciais/Anos Finais. Brasília, 2018

[6] Duckworth, Eleonor. El tener ideas brillantes. In: Scwebel, M ; Ralph, J (org.). Piaget en el aula. Buenos Aires: Huelmul, 1981, p. 319-341

[7] Freire, P. Educação na cidade: projeto pedagógico. São Paulo: Cortez, 1991, p. 58.

[8] Muniz, C. A.; Batista, C. O.; Silva, E. B. da. Matemática e Cultura: Medidas e Sistema Monetário. Brasília: Universidade de Brasília, 2008. 
[9] Ocde. El programa PISA de la Ocde - qué es y para qué sirve. Paris, 2015. Disponível em <https://www.oecd.org/pisa/39730818.pdf >. Acesso em 27 de abril de 2019.

[10] Piaget, Jean. Epistemologia Genética. Tradução de Álvaro Cabral. São Paulo: Martins Fontes, 2012. Sacristán, J Gimeno. 0 currículo - uma reflexão sobre a prática. Porto Alegre: ArtMed, 2000.

[11] Santomé, Jurjo Torres. Globalização e Interdisciplinariedade - o currículo integrado. Porto Alegre: Artes Médicas, 1998.

[12] Silva, Tomaz Tadeu. Documentos de identidade - uma introdução às teorias e currículo. Belo Horizonte: Autêntica, 2016. 


\section{Capítulo 22}

Sentidos da formação continuada em Matemática: Contribuições do PNAIC em uma Escola Estadual de Araputanga/MT

Jorcélia Erminia da Silva Carneiro

Cláudia Landin Negreiros

Resumo: Este trabalho analisa os efeitos de sentido que ecoam nos discursos de professoras alfabetizadoras de uma escola estadual de Araputanga, Mato Grosso, em relação ao ensino de Matemática, após terem participado da formação do Pacto Nacional pela Alfabetização na Idade Certa (Pnaic) em 2014. Os discursos foram analisados com base na Análise de Discurso francesa. As análises indicam que a formação efetivamente constituiu um divisor de águas no ensino da Matemática praticado pelas professoras. As mudanças destacadas foram em relação a uma maior segurança na condução das aulas e ao uso de jogos e objetos concretos no ensino dos conteúdos.

Palavras-chave: Formação continuada. PNAIC. Alfabetização matemática. Análise de Discurso. 


\section{INTRODUÇÃO}

Nesta pesquisa, são apresentados recortes dos resultados de uma pesquisa de Mestrado sobre o processo de formação continuada ofertado pelo Pacto Nacional pela Alfabetização na Idade Certa (PNAIC) para a disciplina de Matemática. Seguindo os procedimentos da Análise de Discurso (AD) de linha francesa, principalmente com base nos trabalhos de Pêcheux (2009) e de Orlandi (2009), foram analisados os discursos de três professoras alfabetizadoras que atuam na rede estadual de ensino do município de Araputanga, estado de Mato Grosso, e que receberam a formação do Pnaic no ano de 2014. Foram consideradas, principalmente, as percepções dessas professoras sobre as reais contribuições da formação para a prática pedagógica na disciplina de Matemática. 0 corpus da análise foi constituído pelos discursos obtidos em entrevistas semiestruturadas, conduzidas com base em questionamentos em relação às práticas pedagógicas das participantes antes e depois do Pnaic de 2014. Para as análises, foi mobilizada, principalmente, a noção de discurso na sua relação com os efeitos de sentidos.

O programa aqui em questão, o Pnaic, representa um compromisso assumido pelos governos das esferas federal, estadual e municipal, cujo objetivo é assegurar que todas as crianças brasileiras estejam plenamente alfabetizadas ao final dos três primeiros anos do Ensino Fundamental. Para isso, foram desenvolvidas diversas ações, que contaram com materiais didáticos e referências curriculares e pedagógicas disponibilizados pelo Ministério da Educação (MEC), voltados para a alfabetização e o letramento. No estado de Mato Grosso, o MEC, a Universidade Federal do Mato Grosso (UFMT) e as várias secretarias municipais de educação combinaram esforços para a implantação e a realização do processo formativo dos professores alfabetizadores atuantes nos três primeiros anos do Ensino Fundamental nas redes municipal e estadual de ensino.

Neste trabalho, o interesse pelo tópico da formação de professores está ligado, principalmente, à intenção de compreender as possíveis contribuições do Pnaic para a práxis pedagógica dos professores cursistas. Considerando esse interesse, foi formulada a questão central que constituiu o problema da pesquisa: quais as contribuições do Pnaic Matemática de 2014 para possíveis mudanças nas práticas pedagógicas dos professores alfabetizadores que ensinam essa disciplina nos anos iniciais de uma escola estadual localizada no município de Araputanga? Assim, o objetivo geral proposto foi o de analisar os efeitos sentidos que ecoam nos discursos dos sujeitos-professores-alfabetizadores (SPAs) em relação ao ensino de Matemática, após a formação continuada proporcionada pelo programa em questão.

Conforme já foi adiantado, com base nos pressupostos da $\mathrm{AD}$, são analisados os efeitos de sentidos que ecoam nas vozes das professoras alfabetizadoras participantes do estudo, a fim de identificar como, de acordo com as suas próprias percepções, ensinavam Matemática e como passaram a ensinar. 0 curso de formação continuada proporcionado pelo Pnaic, destinado aos professores que atuam nos anos iniciais, apresentou-se, nesse contexto, como uma possibilidade de reflexão sobre as práticas pedagógicas dessa disciplina no Brasil, mais precisamente no oeste do estado de Mato Grosso.

Para as análises, foi mobilizada, principalmente, a noção de efeitos de sentidos. Para a AD, o discurso pode ser definido como "efeitos de sentido entre locutores" (Orlandi, 2009, p. 21). Essa noção de "efeitos de sentido" refere-se ao "efeito produzido pela inscrição da língua na história, regido pelo mecanismo ideológico" (Orlandi, 2009, p. 21). Somente por meio da interpretação é possível desvelar essa relação da língua com a história e a ideologia. Nas análises conduzidas neste estudo, procuramos precisamente tornar claras tais relações, conforme elas aparecem nos discursos das participantes.

Este artigo encontra-se estruturado em cinco seções, para além desta introdução e das considerações finais. Nas primeiras seção, propomos uma contextualização da formação continuada de professores, do Pnaic e da Análise de Discurso. Em seguida, apresentamos a metodologia da pesquisa. A última seção antes das considerações finais, por sua vez, apresenta as análises e os resultados.

\section{A FORMAÇÃO CONTINUADA DE PROFESSORES QUE ENSINAM MATEMÁTICA NOS ANOS INICIAIS}

A formação continuada de professores alfabetizadores no Brasil constitui temática de discussões recorrentes e vem se apresentando como uma possível alternativa ao tratamento das várias lacunas decorrentes da formação inicial. Tais lacunas, segundo Nacarato (2005), são um continuum. 0 modo como a Matemática é ensinada faz com que essa disciplina tão necessária na vida social esteja ligada a altos índices de fracasso escolar. É possível constatar essa situação de fragilidade da Educação brasileira em relação à disciplina nos próprios índices nacionais, como é o caso do Índice de Desenvolvimento da Educação Básica (Ideb). 0 cálculo desse índice toma como base os dados retirados do censo escolar e do desempenho dos alunos em avaliações externas, como a Provinha Brasil. 
Considerando as especificidades do conhecimento matemático, Cunha (2010) afirma que os dois elementos fundamentais para o trabalho docente no ensino dessa disciplina nos anos iniciais são, por um lado, domínio do conteúdo, e, por outro, domínio pedagógico do conteúdo. Para a autora, o primeiro elemento não deve ficar restrito ao que o professor dos anos iniciais precisa ensinar, devendo ir além disso. Na mesma direção, Curi (2004, p. 49) afirma:

As considerações das especificidades de cada 'área do conhecimento' com as quais o professor vai trabalhar é certamente um desafio para os programas de formação de professores. Na área de Educação matemática, as investigações sobre o conhecimento de conteúdos matemáticos, o conhecimento didático desses conteúdos e o conhecimento dos currículos de matemática, relativos aos anos iniciais do Ensino Fundamental, têm, a nosso ver, uma forte demanda.

Gatti (2013, p. 54) explica também que os professores devem ser "profissionais detentores de ideias e práticas educativas fecundas, ou seja, preparados para a ação docente com consciência, conhecimentos e instrumentos". Por isso, a preocupação com a formação do professor de anos iniciais para o ensino de Matemática tem sido foco de alguns pesquisadores. A existência de uma formação inicial muitas vezes precária, que não se constitui como um espaço de aprendizagem sólido e não valoriza os conhecimentos e as experiências do professor, implica a necessidade de que sejam propostas alternativas ao modelo atual.

Segundo Imbernón (2010, p. 37), a precariedade está também ligada a uma formação que "exige do professor que ele faça mudanças em sua prática pedagógica, sem que esteja convencido teórica, e experiencialmente, de que elas são necessárias". Consequentemente, sempre que as práticas formativas desconsiderarem o contexto em que os professores atuam e não respeitarem o tempo necessário para a apropriação das novas propostas, em conjunto com os seus pares, os transtornos acontecerão, trazendo mais trabalho que benefícios, chegando até mesmo a comprometer o desenvolvimento dos processos de ensino e de aprendizagem.

Nas décadas de 1980 e 1990, surgiu, no Brasil, um movimento de educadores em prol de um ensino da matemática contextualizado, lúdico e pautado na resolução de situações-problema. Esse movimento questionava os princípios da Matemática moderna e as propostas de formação de professores, vislumbrando a construção de novos caminhos para ensinar e aprender a disciplina por meio de investigações no chão da escola e por meio da formação permanente de professores (Muniz, 2009).

Para Muniz (2009, p. 25), "o movimento de Educação matemática surge da necessidade de repensar o papel do professor frente à criança, vista como produtora de conhecimento matemático". Esse movimento teve como ápice a fundação da Sociedade Brasileira de Educação Matemática. No mesmo período, cresceu o interesse de pesquisadores pelo desenvolvimento de estudos mais profundos, que tratassem das várias dimensões do aprender e ensinar Matemática. A partir daí, criou-se institucionalmente um campo de investigação da Educação matemática. Fiorentini e Lorenzato (2004) afirmam que a disciplina é um meio e um instrumento que contribui para a formação intelectual das crianças e dos próprios professores. Por esse motivo, é importante pensarmos em uma Educação pela Matemática, colocando essa área do conhecimento em protagonismo. Assim, muitos pesquisadores têm investigado a formação dos professores que ensinam Matemática nos anos iniciais, mesmo entendendo que, isoladamente, a formação não resolve todas as dificuldades relacionadas ao ensino e à aprendizagem dessa área do conhecimento.

Nesse contexto, a pesquisa deve ser vista como elemento essencial para a melhoria da qualidade da Educação brasileira, capaz de apontar possíveis caminhos para um ensino que proporcione aprendizagens significativas para as crianças, além de uma ampliação da visão sobre a determinação de novos espaços de investigação. Compreendemos que um desses espaços é a própria escola. Nacarato (2005, p. 176) afirma o seguinte sobre a pesquisa:

As pesquisas sobre formação de professores vêm apontando a importância da escola e do trabalho colaborativo como instâncias de desenvolvimento profissional, uma vez que estas proporcionam aos professores condições de formação permanente, troca de experiências, busca de reivindicações e de soluções para os problemas que emergem do cotidiano escolar.

Considerando o que afirma o autor, compreendo que a formação em serviço, tendo como lócus a escola, contribui para a construção de relações que superam as ações individuais, direcionando as práticas rumo à construção de um trabalho coletivo, com mais potencial de sucesso. Isso acontece sem que deixem de ser respeitadas as características individuais e as vivências pessoais e profissionais próprias de cada sujeito. 
A formação continuada também facilita a composição de grupos de estudos, nos quais os sujeitos investigam e refletem sobre a própria prática. Fiorentini e Nacarato (2004, p. 9) revelam que, nesses grupos, o professor constitui-se como um "agente reflexivo de sua própria prática pedagógica, passando a buscar, autônoma ou colaborativamente, subsídios teóricos e práticos que ajudem a compreender e a enfrentar os problemas" do trabalho docente. Esses autores alertam ainda para a necessidade de essas ações serem realizadas de modo organizado, configurando uma práxis pedagógica que supere o senso comum, em direção à autonomia e ao desenvolvimento profissional. Esses são os princípios expressos do PNAIC, programa cujo perfil traçamos sucintamente no tópico a seguir.

\section{O PNAIC}

No PNAIC, a Formação Continuada de Professores Alfabetizadores potencializa-se a partir do processo de formação entre pares, em curso presencial. O programa é uma política educacional do MEC, que conta com a participação articulada entre o Governo Federal, Estaduais e Municipais e o Distrito Federal, dispostos a mobilizar esforços e recursos, tendo em vista a valorização dos professores e dos alunos e está previsto no Plano Nacional de Desenvolvimento da Educação (PDE), como meta do Plano Nacional de Educação (PNE). Ele se apresenta como uma tentativa de garantir o direito de alfabetização plena a meninas e meninos até o 3. ano do ciclo de alfabetização (Brasil, 2012).

O PNAIC delineou princípios orientadores para a formação continuada dos professores alfabetizadores pautados na prática da reflexibilidade, da constituição da identidade profissional, da socialização, do engajamento e da colaboração. Três grandes grupos compõem o programa: os professores formadores, os professores orientadores de estudo e os professores alfabetizadores que trabalham diretamente com as crianças. Esse tripé mobiliza diferentes saberes, que se materializava em práticas escolares; estas, por sua vez, devem se traduzir em conhecimentos efetivos para as crianças.

0 programa pretende ainda proporcionar apoio pedagógico a professores, com base em diversos materiais didáticos para as crianças do ciclo de alfabetização, e com a promoção de sistemas de avaliação, gestão e monitoramento, adotando como referência o Decreto n. 6.094, de 24 de abril de 2007. As ações desenvolvidas foram distribuídas por quatro eixos de atuação, interligados entre si, que garantem o cumprimento dos objetivos estabelecidos. Listamos tais eixos a seguir:

1. eixo - Formação Continuada de Professores Alfabetizadores, que ocorre por meio de um curso presencial, com dois anos de duração e carga horária de 120 horas por ano.

2. eixo - Materiais didáticos e pedagógicos, integrados por um conjunto de materiais específicos para a alfabetização como, por exemplo, livros didáticos, obras pedagógicas complementares aos livros didáticos e acervos de dicionários de Língua Portuguesa; jogos pedagógicos de apoio à alfabetização; e obras de referência de literatura e de pesquisa.

3. o eixo - Avaliações, eixo que engloba três componentes centrais: avaliações processuais; disponibilização de um sistema informatizado, no qual os professores inserem os resultados da Provinha Brasil de cada criança, no início e no final do 2.ำ ano; e aplicação de uma avaliação externa universal aos alunos concluintes do 3. ano pelo Instituto Nacional de Estudos e Pesquisas Educacionais Anísio Teixeira (INEP).

4.ำ eixo - Gestão, Controle Social e Mobilização, que se refere à organização institucional proposta para reger o Pnaic e é formada por quatro instâncias: a) Comitê Gestor Nacional; b) coordenação institucional em cada estado; c) coordenação estadual; e d) coordenação municipal.

No Estado de Mato Grosso, foram convidados a participar da formação do PNAICc todos os professores que atuavam na alfabetização de crianças em escolas públicas da rede municipal e estadual. A universidade formadora foi a UFMT.

\section{A ANÁLISE DE DISCURSO E OS EFEITOS DE SENTIDO}

Conforme já adiantado, esta pesquisa adotou como base teórica a AD, criada por Michel Pêcheux e divulgada no Brasil por Eni Orlandi. Como instrumento de análise para as produções discursivas, essa corrente leva em consideração o homem inserido na sua história e os processos e as condições de produção da/na linguagem, tanto a relação entre a língua e os sujeitos que a falam quanto as situações histórico-ideológicas em que se produz o dizer. 
Trabalhar com AD é pretender, por meio do discurso, anular as pretensas evidências "naturais" que criam a falsa aparência da existência de um sentido literal nas palavras e expressões. Para Pêcheux (2009), o discurso tem sentido apenas entre interlocutores - o sentido que parece evidente e que é tomado como natural em um dado contexto e que reflete os efeitos da ideologia:

É a ideologia que fornece as evidências pelas quais 'todo mundo sabe' o que é um soldado, um operário, um patrão, uma fábrica, uma greve, etc., evidências que fazem com que uma palavra ou um enunciado 'queiram dizer o que realmente dizem' e que mascaram assim sob a transparência da linguagem' aquilo que chamaremos o caráter material do sentido das palavras e dos enunciados. (Pêcheux, 2009, p. 160).

A ideologia, para o autor, contribuiu para a formulação do conceito de "formações ideológicas", por sua vez ligado ao de "condições de produção". "As condições de produção, num sentido estrito, dizem respeito às circunstâncias da enunciação, ao contexto imediato, e, num sentido mais amplo, ao contexto social, histórico e ideológico", como afirma Orlandi (2009, p. 30). A autora (2009, p. 15) explica que a AD não tem como objeto de estudo a língua, pois procura-se antes "compreender a língua fazendo sentido, enquanto trabalho simbólico, parte do trabalho geral, constitutivo do homem e de sua história".

0 discurso implica uma exterioridade à língua, pois se presentifica no social e inscreve-se na história. Por isso, segundo Orlandi (2009), em uma menção à teoria da comunicação, o discurso não se confunde com a mera transmissão de informação; não é simplesmente um processo linear, sequencial, no qual um fala e o outro, assimila. Para o analista de discurso, o objeto é o discurso. Orlandi (2009) afirma também que o discurso não pode ser confundido com "mensagem" ou "fala". A AD não entende língua e sujeito como instâncias transparentes. 0 sujeito, afetado pela ideologia e pelo inconsciente, interpreta os sentidos do discurso a partir das condições sócio e historicamente determinadas. Assim sendo, nas diversas formações discursivas, não há apenas um intuito de transmissão de informações. Oportunamente, Orlandi esclarece o seguinte:

A Análise de Discurso, como seu próprio nome indica, não trata da língua, não trata da gramática, embora todas essas coisas lhe interessem. Ela trata do discurso. E a palavra discurso, etimologicamente, tem em si a ideia de curso, de percurso, de correr por, de movimento. O discurso é assim palavra em movimento, prática de linguagem: com o estudo do discurso observa-se o homem falando. (Orlandi, 2009, p. 15).

Considerando essas observações da autora, compreende-se que o objeto histórico-ideológico, o discurso, é produzido de maneira social, adotando a língua como base material. Por se tratar de uma produção social, suas regularidades somente são apreendidas com a análise do processo de sua produção, jamais de seus produtos, pois a dispersão de textos, de sujeitos e de sentidos e de seu funcionamento advém da própria noção de linguagem.

Ao nos referirmos à produção de sentidos, entendemos que, no discurso, eles não são fixos; antes, são produzidos sempre em relação ao lugar de fala ocupado pelos sujeitos em interlocução e em decorrência da formação discursiva que os constitui. 0 processo de análise da AD procura levar em conta os outros discursos não ditos e esquecidos para compreender os efeitos de sentido entre locutores. Orlandi (2009) afirma que o método analítico em questão procura compreender o funcionamento dos sentidos, uma vez que AD é uma disciplina de interpretação que busca problematizar o valor do discurso, explicitando como certos sentidos ocultos são possíveis. Compreender é, assim, conhecer os mecanismos pelos quais se põe em jogo um determinado processo de significação.

É oportuno enfatizar que o sentido não é determinado apenas pelo locutor ou pelo interlocutor - há sempre negociações. Por isso, a expressão linguística associada aos discursos é de natureza social e não individual; o sentido não tem origem na linguagem e nem nos interlocutores, mas constitui-se na relação entre estes no uso da língua, diante das condições sociais de produção do enunciado. Desse modo, o sentido, compreendido aqui como efeito, não é algo que resulta do enunciado em si, mas da relação de pertencimento que ele mantém com sentidos já produzidos e reconhecidos socialmente.

Os efeitos de sentido surgem quando o sujeito, afetado pela história, exprime a forma como foi afetado inconscientemente pelo meio circundante e exterioriza ideologias em sua discursividade: "[...] reunindo estrutura e acontecimento, a forma material é vista como o acontecimento do significante (língua) em um sujeito afetado pela história" (Orlandi, 2009, p. 29). 
A materialidade do discurso traz efeitos que atingem os sujeitos, à revelia de suas vontades. Quando falamos, filiamo-nos involuntariamente às redes de sentidos que nos são externas. A AD propõe, então, que se levem em conta os efeitos produzidos a partir do lugar de onde o sujeito fala, agindo sobre outros interlocutores. Orlandi (2009, p. 60) afirma que "[...] uma mesma palavra, na mesma língua, significa diferentemente, dependendo da posição do sujeito e da inscrição do que diz em uma ou outra formação discursiva" - ou seja, segundo a autora, o efeito de sentido é efeito produzido pela inscrição da língua na história, o que é regido por um mecanismo ideológico. É a interpretação que tornará visível a relação da língua com a história e a ideologia (Orlandi, 2009, p. 21).

Nesta pesquisa, procuramos, assim, substancialmente, explicitar os processos discursivos que permeiam os discursos dos sujeitos pesquisados, aclarando os efeitos de sentido a que eles remetem. Compreender como se dá a representação discursiva de uma realidade específica, a da Alfabetização Matemática antes e depois do Pnaic, foi a intenção das análises, sustentadas teoricamente pela AD.

\section{ASPECTOS METODOLÓGICOS}

Nesta pesquisa, foi adotada a abordagem qualitativa, uma vez que ela possibilita maior aproximação em relação ao objeto de estudo, disponibilizando uma base teórica que permitiu lidar com a perspectiva de quem participou ativamente da formação do Pnaic, de quem vivenciou todas as etapas propostas pela formação. Conforme afirmam Bogdan e Biklen (1994), a pesquisa qualitativa não objetiva testar hipóteses, e as questões investigadas não se explicitam mediante operacionalização de variáveis, o que permite a investigação dos fenômenos em toda a sua complexidade e em contexto natural. Os autores destacam também que os depoimentos dos participantes da pesquisa, na produção de dados qualitativos, "privilegiam, essencialmente, a compreensão dos comportamentos a partir da perspectiva dos sujeitos investigados" (Bogdan; Biklen, 1994, p. 16).

Ainda segundo Bogdan e Biklen (1994, p. 49), "o significado que os sujeitos participantes da pesquisa atribuem às coisas e a sua vida" também é importante para o conhecimento humano. Na abordagem qualitativa, buscam-se compreender as perspectivas de como os participantes veem e sentem o objeto investigado. Nesta pesquisa, entendemos que a metodologia aqui adotada nos permitiu, por meio do contato direto entre sujeito pesquisador e SPAs, compreender melhor como se deu o processo de formação do Pnaic Matemática e o sentido que lhe foram atribuídos.

Foram dois os instrumentos da pesquisa: questionários e entrevistas semiestruturadas. Os questionários foram utilizados para obter dados objetivos sobre as participantes (idade, formação, experiência profissional) e sobre o lócus da pesquisa, a escola onde as participantes atuam (estrutura e organização, acervos de materiais pedagógicos e multimídias à disposição dos professores etc.). 0 questionário foi respondido pelos SPAs apenas após um expresso assentimento, que oficializou o início da investigação.

As entrevistas semiestruturadas foram conduzidas em 2018. Esse instrumento foi usado de modo a darmos voz às participantes e a posicioná-las como autoras de sua própria história. Foram feitas perguntas em relação às práticas pedagógicas das professoras antes e depois do Pnaic de 2014. Em seguida, as falas foram transcritas e analisadas, conforme expomos na seção a seguir. Procuramos, assim, perceber se podemos falar em um antes e em um depois do programa e se as orientações sugeridas foram incorporadas pelas participantes, mesmo após passados quatro anos da formação.

Participaram do estudo três professoras alfabetizadores que fizeram parte do grupo da formação continuada do Pnaic no ano de 2014, no município de Araputanga. A idade média das participantes foi de 36 anos, tendo, à época da realização da pesquisa, a mais nova 35 anos e a mais velha, 39. Localizado na região sudoeste do estado de Mato Grosso, a $345 \mathrm{~km}$ da capital Cuiabá, com uma área territorial de 1610 $\mathrm{km}^{2}$, o município em questão tinha, em 2017, uma população estimada de apenas 16.223 habitantes, de acordo com o IBGE (2018). Trata-se uma cidade de pequeno porte, com uma economia baseada no agronegócio (bovinocultura de corte e leiteiro). A rede de ensino local é formada por oito unidades da rede municipal e quatro unidades da rede estadual, numa das quais encontramos as participantes deste estudo. Em relação às entrevistas, duas foram previamente agendadas via e-mail; uma foi agendada por telefone. Os encontros ocorreram no interior da escola, durante o período de hora-atividade de cada SPA. 


\section{ANÁLISES E RESULTADOS}

0 roteiro das entrevistas contemplou aspectos que consideramos fundamentais para conhecermos as percepções dos sujeitos em relação à formação continuada do Pnaic e aos impactos do programa na prática em sala de aula. Após várias leituras do corpus empírico, iniciamos o movimento de seleção das Sequências Discursivas (SDs), que constituem o corpus discursivo, privilegiando trechos que se destacavam pela sua riqueza de conteúdo. A partir disso, foram aplicados os procedimentos descritivos e interpretativos característicos da AD. Com o intuito de assegurar o anonimato das participantes, optamos, nesta seção, por referenciá-las da seguinte forma, sem o uso de artigos definidos ("o", "a", "os" ou "as"): "SPA1", "SPA2" e "SPA3".

Com o objetivo de identificar de que modo e em que medida o Pnaic contribuiu para a formação continuada e para a práxis pedagógica das professoras entrevistadas, foram feitas as seguintes questões: 1) na sua opinião, ocorreram mudanças em sua maneira de ensinar Matemática após a formação do Pnaic? Se sim, quais mudanças foram essas?; e 2) como está a sua práxis pedagógica em Matemática após formação do Pnaic? Foi ainda solicitado às professoras que discorressem livremente sobre o Pnaic em Matemática no ano de 2014 e listassem pontos positivos e negativos dessa formação. Além disso, analisamos também as dificuldades vivenciadas por essas profissionais durante o curso. Portanto, é de tais questionamentos que advêm os recortes aqui analisados.

Quando instadas a discorrerem livremente sobre o Pnaic em 2014, SPA1 e SPA3 responderam do seguinte modo:

SD01: Foi excelente essa formação. Ao meu ponto de vista, porque nós estudamos cada eixo estruturante da área da Matemática, individualizado, como material já impresso, pronto, pudemos tirar dúvidas. É, nas formações, tinha muitas discussões sobre os termos, conceitos... Ajudou muito mesmo a melhorar os conhecimentos na área da Matemática. (SPA1, 2018, entrevista).

SD02: Então, a [formação em] Matemática veio, assim, para abrir a minha cabeça sobre Matemática, porque, e SPA3 responderam do seguinte modo: como assim, eu não tive, assim, uma prática na sala até então, até o Pacto, muito boa. Veio, assim, pra me abrir um horizonte mesmo, dá um norte sobre a ludicidade, sobre como trabalhar com a criança, me ajudou muito o Pnaic. (SPA3, 2018, entrevista).

As sequências discursivas destacadas revelam que as professoras entrevistadas se reportam ao Pnaic como tendo sido uma experiência essencialmente positiva. SPA1 afirma que a formação foi "excelente" e justifica a sua opinião aludindo ao fato de o programa ter proporcionado uma formação substancial e completa, abordando cada "eixo estruturante" da Matemática, o que ajudou, assim, a consolidar conhecimentos na área. A professora destaca, desse modo, as contribuições teóricas trazidas pelo programa. Nessa fala, está implícita a concepção de que o domínio de conceitos e de terminologia é importante para a prática pedagógica da disciplina em questão. SPA3, por outro lado, embora também afirme que a formação a tenha ajudado, focaliza a justificativa aluindo às contribuições práticas trazidas pelo Pnaic. As professoras destacam diferentes aspectos das contribuições do programa, permitindo afirmar que a formação em questão não se limitou à dicotomia "teoria vs. prática", mas buscou lançar contribuições em várias frentes.

SPA3 reitera, ainda, a ideia de que a sua prática, "até o Pacto", não era "muito boa". Isso reforça a concepção de que o programa foi um divisor de águas em sua carreira. É oportuno destacar os efeitos de sentido ligados às expressões que a professora mobiliza para aludir ao modo como o programa a "ajudou muito". Para a entrevistada, o Pnaic "abriu horizontes" e "deu um Norte". Tais expressões remetem ao sentido de que, mais do que apresentar um conjunto estanque de ferramentas, a formação constituiu um ponto de partida, oferecendo aos cursistas um universo de possibilidades a ser desenvolvido e explorado de forma autônoma. Os semas da amplitude e da completude são, pois, aqui mobilizados. Por contraste, o ensino pré-formação é consequentemente retratado como algo confinado, preso a práticas limitadoras. Por sua vez, ao discorrer sobre o Pnaic, SPA2 afirma o seguinte:

SD03: [...] foi uma atividade boa, foi onde eu passei a me interessar um pouquinho mais pela Matemática. Vamos dizer assim: não é interessar, gostar, pra transferir melhor para os alunos. Por já ter esse bloqueio, anteriormente, de não gostar da Matemática, eu consegui com que, através dos jogos, que a gente fez bastante... Nesse, nesses encontros na Matemática, fez com que eu 
conseguisse gostar da Matemática e não transferi aquele receio e aquele medo para meus alunos. Que sempre quando me perguntavam: 'qual a matéria que você gosta professora?', 'Todas, menos Matemática'. E respondia mesmo que eu não era muito fã de Matemática... E agora eu gosto de Matemática - gosto, não: amo! (SPA2, 2018, entrevista).

Nesse recorte, SPA2 também considera que o Pnaic foi positivo. Contudo, diferentemente das colegas, ao discorrer sobre as razões que sustentam a sua opinião, a entrevistada alude ao fato de que o programa modificou profundamente a sua relação afetiva com a Matemática: "e agora eu gosto de Matemática". A fala da professora enfatiza o caráter multívoco do programa, que atuou não só consolidando conhecimentos e modificando práticas, conforme afirmam SPA1 e SPA2, mas também conseguiu mobilizar fenômenos afetivos. Diversos autores defendem a ideia de que a afetividade é um dos fatores responsáveis por impulsionar o indivíduo no sentido de obter conhecimento, estando ligada ao interesse e à motivação. Piaget (2005), por exemplo, afirma que os desenvolvimentos cognitivo e afetivo acontecem simultaneamente, de forma independente. No recorte em questão, SPA3 aponta, portanto, para outra função importante do programa: a de modificar o modo como muitos cursistas se relacionavam com uma disciplina que é tida como inacessível e enfrenta um alto índice de rejeição.

Dando prosseguimento às análises, vejamos agora como as entrevistadas responderam à pergunta: "na sua opinião, ocorreram mudanças em sua maneira de ensinar Matemática após a formação do Pnaic? Se sim, quais mudanças foram essas?".

SD04: Sim, eu considero que sim, muitas mudanças. Eu inovei as minhas aulas, assim, eu mudei bastante, para melhor. (SPA1, 2018, entrevista).

SD05: Ocorreu [...] que antes eu pensava de uma forma, até não gostava, e agora eu já passei a gostar... A tentar levar para meus alunos esse lado gostoso que é a Matemática, você levar para sala de aula objetos. Tudo que você envolve a Matemática para estar ensinando. Foi bem melhor. (SPA2, 2018, entrevista).

SD06: Sim, com certeza, totalmente, minha cabeça mudou muito a forma de abordar a criança. Como é, colocar, assim, a criança em primeiro lugar, como trabalhar atividade com a criança, ludicidade, a forma adequada. (SPA3, 2018, entrevista).

Esses recortes guardam uma relação de harmonia com a direção argumentativa que as entrevistadas vinham imprimindo ao discorreram sobre os efeitos da formação do Pnaic. Nessas falas, o discurso está organizado à volta da ideia de "mudança". Essa palavra, em vários momentos dos recortes, é reiterada com recurso à sinonímia, à intensificação e à paráfrase: "inovei", "mudei bastante", "passei a gostar", "bem melhor", "mudou muito". Pode-se afirmar que a onipresença desse vocábulo faz com que o discurso materializado nesses enunciados seja atravessado pela reiteração da ideia de um "antes" e de "depois" bastante marcados. É oportuno frisar que o vocábulo "mudança" é neutro, não mobilizando necessariamente ideias negativas ou positivas; a ideia de "evolução", pelo contrário, é que está sempre ligada ao aperfeiçoamento de alguma coisa. Por esse motivo, as entrevistadas reforçam os efeitos de sentido positivos trazidos pelo Pnaic com o recurso à reiteração dos advérbios "muito", "bastante" e "melhor". Eles reforçam a ideia de que as mudanças operadas foram profundas e positivas, tratando-se, portanto, de uma evolução. O uso do verbo "inovar" reforça essa ideia, uma vez que é um termo comumente relacionado à criatividade e à modernização - ideias comumente positivas. Mais uma vez, o discurso das professoras aponta para uma valorização da novidade e da diversidade, marcando uma forte oposição em relação à ideia de um ensino tradicional. Vários pares antitéticos vão, assim, se delineando nas falas das entrevistadas como um todo: antes vs. depois do Pnaic; ensino baseado em métodos mecanizados e repetitivos vs. ensino inovador; novidade vs. repetição.

Nas últimas três sequências discursivas citadas (SD04, SD05 e SD06), as entrevistadas destacam o uso de objetos, a ludicidade e a preocupação com a necessidade dos alunos. Esses elementos podem ser lidos como índices das mudanças a que as professoras se referem. A menção à priorização das características do público em questão ("as crianças em primeiro lugar") revela por parte das professoras, a adesão a uma Educação humanística, que coloca ênfase nos processos de interação professor-aluno. Os discursos sugerem que antes não havia tão ênfase. Tais professoras "veem a educação como um processo de crescimento pessoal, interpessoal e grupal em que o professor atua como o facilitador desse crescimento" (Gil, 2007, p. 36). Pode-se afirmar, a partir das falas analisadas, que o Pnaic ajudou a promover tal concepção. 
Ainda pensando no estabelecimento de antíteses, outro aspecto de um desses recortes merece a nossa atenção. SPA2 utiliza o vocábulo "gostoso" para se referir à Matemática. O Pnaic possibilitou que a professora tentasse levar seus alunos até "esse lado gostoso que é a Matemática". Ao caracterizar a disciplina com uma palavra comumente associada ao paladar, mobiliza-se a ideia de que a Matemática pode ser algo prazeroso, desde que o professor saiba conduzir os alunos. Para isso, segundo SPA2, uma formação adequada é essencial. De fato, segundo ela, graças ao Pnaic é que as professoras conseguiram abandonar um estágio em que nutriam verdadeira ojeriza pela disciplina, e mudar para outro em que são capazes de enxergar que a Matemática pode ser algo prazeroso. Fica também implícita a ideia de que desfrutar desse prazer que a disciplina proporciona requer uma intermediação - no caso das professoras, o Pnaic cumpriu esse papel; no caso dos alunos da Educação Básica, coube às professoras desempenhar tal função, aplicando o que haviam aprendido. Note-se que SPA1 afirma que "tentou levar" os alunos a uma outra percepção da disciplina, sugerindo a ideia de uma espécie de rito de passagem, uma transição entre um estágio em que o mais natural é não gostar da Matemática, para um em que se percebe que a disciplina é algo "gostoso". O efeito de sentido mobilizado é o de que a Matemática é um campo de saberes sui generis, que à partida é recebido com rejeição. Note-se, por último, que SPA3 alude à ideia de uma prática "adequada". Os efeitos de sentido produzidos por esse adjetivo, nas sequências discursivas em questão, implicam a ideia de que, na concepção das entrevistadas, existe um modo correto de trabalhar os conteúdos, modo esse a que as professoras tiveram acesso graças ao Pnaic. Isso demonstra uma plena confiança no programa.

Quando questionadas sobre as dificuldades que sentiram em relação à aplicação da proposta da formação, SAP2 e SPA3 discorreram do seguinte modo:

SD07: Senti por não gostar de Matemática. Na época, eu senti muita dificuldade [de] fazer algumas atividades, de criar alguns jogos, no começo [e] até depois. Desembaraçando o fio da meada, eu consegui ir mais além. Até eu acho que eu tenho mais facilidade em criar jogos de Matemática, os jogos de Matemática para estar ensinando, do que em outras matérias. (SPA2, 2018, entrevista).

SD08: Na aplicação da proposta, devido aos materiais que tínhamos que elaborar, muitos jogos, muitos brinquedos, tivemos um pouco de dificuldade sim, mas, como eu disse, os jogos, só vieram para ajudar mesmo. Então, essas dificuldades, todas as escolas eu acredito que passaram um pouco por isso, mas a gente encontrou bastante dificuldade em fazer os brinquedos, em fazer os materiais que a escola não proporcionava. (SPA3, 2018, entrevista).

As falas reproduzidas apontam para o fato de que o Pnaic foi um programa capaz de angariar grande aceitação e prestígio entre as professoras. Nos recortes destacados, pode ser identificada uma estrutura concessiva, que atenua os sentidos das dificuldades a que as entrevistadas aludem. SPA2 menciona que as dificuldades que sentiu estiveram relacionadas à sua própria relação com a Matemática, posicionando a culpa em uma razão pessoal, e não em algum aspecto que desabonasse o programa propriamente dito. Novamente, o contraste entre um "antes" e um "depois" é reforçado: no período que antecedeu o Pnaic, SPA2 tinha dificuldade com a feitura de jogos; hoje, no pós-programa, elabora-os de modo "até" melhor do que o das outras disciplinas. SPA3, por sua vez, também fala da dificuldade em lidar com os muitos jogos e brinquedos. A ideia concessiva, que atenua o tom de crítica, é estabelecida pela menção de que os jogos "só vieram para ajudar mesmo". Além disso, essa dificuldade é naturalizada pela ideia de que todas as escolas passaram pelo mesmo - a dificuldade é como que legitimada pelas condições estruturais das escolas brasileiras. Por parte das professoras, há, portanto, uma plena adesão aos dispositivos do programa.

0 fato de as entrevistadas listarem a elaboração de jogos como sendo uma das principais dificuldades que sentiram é algo sintomático. Por um lado, esse fato revela uma baixa presença de tais estratégias nas práticas das professoras antes da formação que receberam em 2014, permitindo concluir que elas não estavam habituadas a trabalhar com tais recursos. Entende-se atualmente que o brincar é uma atividade inerente ao ser humano. A importância dos jogos e dos brinquedos e a sua relação com o desenvolvimento e a aprendizagem têm sido investigadas por vários pesquisadores, que têm mostrado as contribuições dessas estratégias para o ensino de crianças (Oliveira; Gomes, 2008). Sabemos que, mesmo no espaço de um ensino nos moldes antigos, até pelas particularidades que são próprias da infância, a brincadeira se faz presente. Frisamos, portanto, que as falas das professoras se reportam à ausência de jogos para se trabalhar a disciplina de Matemática. SPA3 afirma abertamente isso em uma de suas respostas: ao lidar com tal disciplina, não considerava a possiblidade de usar os jogos como recursos pedagógicos. Trata-se, assim, de outra contribuição do Pnaic. 
Vejamos, agora, o que afirmam as professoras sobre os pontos negativos relacionados à formação em questão.

SD09: Como pontos negativos, [existe] a questão da dificuldade mesmo de acesso à plataforma e o prazo curto, às vezes, para os professores realizarem as tarefas, estarem entregando. Pra gente sintetizar, os nossos relatórios, os orientadores tinham os relatórios pra fazer; então ficava bem apertado esse prazo, era uma dificuldade também, era um ponto negativo. (SPA1, 2018, entrevista).

SD10: Eu sou interina, então eu participei do Pnaic... todos os que tiveram, menos o ano passado, porque o ano passado eu estava como articuladora e não poderia participar. Como interina, nem sempre dá certo, porque esse ano eu posso estar no terceiro, no segundo e posso fazer, ano que vem... Sobra a sala do quarto ano, então eu já não posso participar. Então, acaba que acaba perdendo o que o Pnaic preza - a continuidade [...]. (SPA2, 2018, entrevista).

SD11: Pnaic é tudo de bom, porém, não dá sequência. É, como nós, interinos, fazíamos o primeiro, o segundo e terceiro ano. Primeiro ano que eu dei, eu dei primeiro, segundo e terceiro ano, fui com a mesma turma; já no outro ano, quarto ano, não teve continuidade, porque mudou tudo... 0 Pacto, antes a prioridade, era pra quem estava fazendo o Pacto, era de pegar a mesma série. Agora não, e, assim, nunca deu uma continuidade, se desse continuidade, eu acho que seria bem gratificante mesmo. (SPA3, 2018, entrevista).

Notamos, nessas sequências discursivas, que os pontos negativos a que aludem as entrevistadas referemse a aspectos extrínsecos ao programa - ou seja, as cursistas não se reportam à didática, ao material ou à concepção do conteúdo da formação propriamente dita, reforçando que existe, por parte das professoras, uma plena adesão aos moldes do programa. SPA3 chega a afirmar que o "Pnaic é tudo de bom", o que reforça essa tese. As críticas recaem sobre a ausência de continuidade e sobre os prazos curtos para a realização de tarefas. A menção à continuidade enfatiza que as professoras valorizam tal prática e enxergam nela benefícios para a aprendizagem dos alunos. Já a queixa quanto aos prazos curtos pode ser lida em consonância com a ideia de que predomina atualmente uma sobrecarga de trabalho para o professor na Educação Básica brasileira e daí a dificuldade de encontrar tempo para realizar as atividades de um programa de formação continuada. Em relação aos pontos positivos, basicamente, as professoras limitaram-se a responder a essa questão em moldes muito semelhantes aos já apresentados em outras oportunidades neste trabalho. É digno de menção, contudo, o comentário que SPA2 faz sobre o material do programa. Vejamos o recorte a seguir.

SD12: 0 [ponto] positivo é que te ensina, ele te motiva; e ajuda você ver muito, tem muitos registros nos fascículos, nos livros, onde mostra experiência de outros professores, então você olha, assim: 'nossa! Aquela cidadezinha minúscula lá do Maranhão, da Bahia, deu certo, porque que a minha não vai dar?'. Então, te estimula, a fazer ali, a trabalhar mais. (SPA2, 2018, entrevista).

A fala da professora aponta para o elemento motivacional presente na formação. De fato, ao apresentar relatos de outros professores, o material do Pnaic incentivava as cursistas a confiarem em si mesmas. Subjaz à fala de SPA2 a ideia de que faltava, às participantes, confiança acerca das suas próprias capacidades - só assim é possível entender os efeitos motivadores que os casos de sucesso advindos de uma "cidadezinha minúscula" tiveram. SPA2 marca uma pretensa superioridade da sua localização em relação aos estados do Maranhão e da Bahia, que geralmente ocupam as últimas posições no Ideb. Mais uma vez, o não-dito e o interdiscurso ajudam na compreensão dessa passagem. 0 raciocínio de que "se eles conseguem, que dirá eu, que sou melhor?" parece ser referendado pelos próprios cadernos. Indagar de perto uma fala como esta permite-nos perceber o grau de insegurança dos professores brasileiros acerca das suas próprias competências, restando-lhes depreciarem certas realidades para fins de autoafirmação. Para, além disso, o que fica evidente é também a realidade heterogênea do país, onde cabe a realidade de Araputanga e a das cidadezinhas minúsculas da Bahia e do Maranhão.

Vejamos, agora, como cada professora discorre a respeito de sua prática pós-Pnaic, uma vez que foi formulada uma pergunta que diretamente endereçava tal tópico - "como está sua práxis pedagógica em Matemática após formação do Pnaic?”. Em seguida, apresentamos as considerações de SPA1. 
SD13: Hoje, eu considero que eu reflito muito na... durante a aula, antes e após pra ver o que o aluno está conseguindo desenvolver, pra mudar. Eu trabalho também dentro do nível do aluno; então, eu sempre estou refletindo, 'será que essa atividade de Matemática está adequada para esse aluno?', e vou buscando sempre melhorar, para que esse aluno cresça em conhecimento formais. (SPA1, 2018, entrevista).

No recorte destacado, o advérbio "hoje", atuando como modalizador temporal, iniciando o discurso da professora, organiza a sua fala sob o signo do contraste - o interlocutor entende que toda a prática que, no texto, sucede a esse advérbio era feita de modo diferente no passado. No recorte, SPA1 destaca como principais mudanças o ato de refletir mais e a preocupação com os alunos. Apontamos, aqui, novamente a presença de uma visão humanística do ensino e da Educação, que coloca o aluno no centro das preocupações do professor. De fato, uma das premissas do Pnaic 2014 foi o de que o letramento matemático deve levar em consideração que o maior desafio do professor que alfabetiza é respeitar o modo de pensar da criança e a mobilização de estratégias pessoais para a resolução de problemas. Dessa forma, segundo os cadernos da formação, o professor deve incentivar a criança a produzir suas próprias estratégias de raciocínio e a argumentar sobre elas. SPA2, por sua vez, começar por reiterar que tudo mudou. A seguir, reproduzimos sua resposta completa a essa questão.

SD14: Tudo mudou... a forma de trabalhar com o aluno, tudo, tudo mudou. Assim, após o trabalho com o Pacto, o aluno... hoje, eu estou na articulação. Hoje, essa reflexão que nós fazemos é muito importante, do que o aluno deve aprender, como o aluno deve aprender, o porquê ensinar dessa forma, se está surgindo algum efeito. Então, tudo isso mudou, após o Pnaic. (SPA2, 2018, entrevista).

O discurso anafórico que marca o primeiro período da fala pode ser lido como uma tentativa do sujeito enunciador de se expurgar de qualquer prática que ligue a sua didática atual à do passado. Portanto, com os efeitos de sentido dessa reiteração, é como se a entrevistada dissesse ao interlocutor: "do passado, não restou nada". A fala sinaliza, consequentemente, a ideia de uma completa transformação operada pelo programa na prática da professora. Novamente, a valorização da reflexão e da preocupação com o aluno se faz presente. Vejamos, por último, o que afirma SPA3 no recorte reproduzido a seguir:

SD15: [A minha prática] Estou cada dia tentando melhorar, estou tentando gostar, estou tentando transferir de forma mais efetiva pra eles, mais gostosa para meus alunos, para que eles também não passem pelo que eu passei... essa questão de bloqueio, de odiar a Matemática... Então, pra mim, eu estou tentando facilitar pra eles, estou tentando fazer o que não fizeram comigo, que é ensinar uma Matemática gostosa, com diversos jogos, brincadeiras, em tudo. (SPA3, 2018, entrevista).

A estrutura anafórica ("estou tentando..., estou tentando..."), que também marca a resposta da entrevistada, produz efeitos de sentido que reforçam no interlocutor a ideia de que, passados quatro anos do Pnaic, as mudanças operadas pela formação ainda estão em curso. Os efeitos de sentidos são os de que a professora concebe a docência como uma prática em constante movimento e aprimoramento, algo que requer, de forma contínua, os esforços do professor.

O programa é, portanto, algo perene, que continua a influenciar a postura da docente em sala de aula. Além disso, ao construir a sua fala desse modo, o sujeito enunciador veicula a ideia de que as mudanças implementadas foram fruto de seu próprio esforço, de um comprometimento pleno com a realidade de seus alunos. Mais uma vez, há a menção aos jogos e às brincadeiras como estratégias de promoção da aprendizagem. Também neste discurso o aluno adquire posição de destaque: o pronome "eles", que remete contextualmente a esse público, é repetido três vezes. Ao afirmar que "estou tentando fazer o que não fizeram comigo", a professora, assim como as suas colegas, revela a intenção de se distanciar das práticas do passado, sabendo dos seus efeitos deletérios.

\section{CONSIDERAÇÕES FINAIS}

Apresentamos, nesta seção, as considerações sobre os resultados das análises. Destacamos, inicialmente, que tais dados foram analisados e respaldados teoricamente sob o viés da AD. De modo algum, apresentamos aqui um resultado final e absoluto; pelo contrário, entendemos que a subjetividade é inerente às investigações qualitativas, e as reflexões aqui apresentadas revelam o olhar do pesquisador, 
limitado a um determinado período de tempo. Levando isso em consideração, estas considerações finais estão abertas a outros sentidos e percepções.

As falas das professoras apontam para o caráter plural da formação do Pnaic recebida em 2014, que atuou não só consolidando conhecimentos e modificando práticas, mas também conseguiu mobilizar fenômenos de ordem afetiva, modificando o modo como os cursistas se relacionavam com uma disciplina que é comumente rejeitada de modo generalizado, inclusive pelos próprios professores.

As sequências discursivas analisadas estão organizadas sob o signo da ideia de "mudança". Essa palavra é reiterada em vários momentos com recurso à sinonímia, à intensificação e à paráfrase. A onipresença de tal vocábulo faz com que o discurso materializado nessas falas seja atravessado pela constante reiteração da ideia de um "antes" e de "depois" bastante nítidos. Desse modo, é possível afirmar que, na visão das professoras, o Pnaic alterou significativamente as práticas pedagógicas em relação à Alfabetização Matemática. 0 uso de objetos, a ludicidade e a preocupação com a necessidade dos alunos surgem nos discursos das entrevistadas como índices das mudanças referidas. Os pontos negativos relacionados ao programa, aos quais as entrevistadas aludem quando instadas a tanto, referem-se a aspectos extrínsecos ou seja, as professoras não se reportam à didática, ao material ou à concepção do conteúdo da formação propriamente dita, o que permite concluir que existe, por parte delas, uma plena adesão ao programa.

Passados cinco anos da primeira edição do Pnaic, os resultados da ANA têm mostrado um tímido avanço em leitura, escrita e Matemática entre 2014 e 2016 para o público-alvo do programa em questão. Dos dois milhões de alunos entre sete e dez anos que fizeram o exame no ano de 2016, apenas 27,11\% obtiveram um nível de proficiência em Matemática considerado desejável; em 2014, eram 25,11\%. Em Mato Grosso, o número é ligeiramente superior à média nacional: 26,4\% (Brasil, 2017). Contudo, pesquisadores da área alertam que tais resultados não são suficientes para se dizer que o Pacto falhou. Os impactos de uma nova política pública costumam demorar um tempo considerável para surtir efeito. Além disso, é preciso considerar a existência de problemas que fogem ao controle do programa - por exemplo, falta de professores concursados em algumas cidades, que fez com que muitos docentes que receberam a formação tinham contrato temporário e foram depois desligados.

A partir dos resultados desta pesquisa, é possível traçar um retrato bastante positivo do Pnaic - pelo menos, em Araputanga. As análises mostraram que o programa logrou uma grande aceitação entre os professores cursistas e que foi capaz de modificar percepções sobre o ensino da Matemática, existindo claramente um "antes e depois" dessa formação, que se apresenta, assim, como um divisor de águas no contexto da formação continuada brasileira. As contribuições do programa não se limitaram apenas ao domínio teórico ou da prática, havendo um entrecruzamento de tais domínios nas falas das entrevistadas, o que aponta para uma superação dessa dicotomia.

\section{REFERÊNCIAS}

[1] Bogdan, R. C.; Biklen, S. K. Investigação qualitativa em educação: uma introdução à teoria e aos métodos. Portugal: Porto, 1994.

[2] Brasil. Secretaria de Educação Básica. Diretoria de Apoio à Gestão Educacional. Pacto Nacional pela Alfabetização na Idade Certa: vamos brincar de construir as nossas e outras histórias: ano 02, unidade 04 / Ministério da Educação, Secretaria de Educação Básica, Diretoria de Apoio à Gestão Educacional. Brasília: MEC, SEB, 2012.

[3] Brasil. Instituto Nacional de Estudos e Pesquisas Educacionais Anísio Teixeira. Resultados da ANA 2016 por estados e municípios estão disponíveis no Painel Educacional do Inep. 2017. Disponível em: https://bit.ly/2JttfLQ. Acesso em: 22 out. 2018.

[4] Cunha, D. R. A matemática na formação de professores dos anos iniciais do ensino fundamental: relações entre a formação inicial e a prática pedagógica. 2010. Dissertação (Mestrado em Educação em Ciências e Matemática). Faculdade de Física, Pontifícia Universidade Católica do Rio Grande do Sul, Porto Alegre, 2010.

[5] Curi, E. Formação de professores polivalentes: uma análise de conhecimento para ensinar matemática e de crenças e atitudes que interferem na constituição desses conhecimentos. 2004. Tese (Doutorado em Educação Matemática). Pontifícia Universidade Católica de São Paulo, São Paulo, 2004.

[6] Fiorentini, D.; Nacarato, A. M. (Orgs.). Eu trabalho primeiro no concreto. Revista de Educação Matemática, Sociedade Brasileira de Educação Matemática - Regional São Paulo, SBEM-SP, 2004.

[7] Gatti, B. A. Educação, escola e formação de professores: políticas e impasses. Educar em Revista, Curitiba, n. 50, p. 51-67, out/dez. 2013.

[8] Gil, A. C. Didática do Ensino Superior. São Paulo: Atlas, 2007. 
[9] IBGE. Instituto Brasileiro de Geografia e Estatística. IBGE. População Araputanga - ano 2018. Disponível em: http://www.cidades.ibge.gov.br. Acesso em: 22 jun. 2018.

[10] Imbernón, F. Formação continuada de professores. Porto Alegre: Artmed, 2010.

[11] Muniz, C. A. Educação e linguagem matemática. Brasília: Universidade de Brasília. Centro de Educação a distância, 2009.

[12] Nacarato, A. M. A escola como lócus de formação e de aprendizagem: possibilidades e riscos da colaboração. In: Fiorentini, D.; Nacarato, A. M. (Org.). Cultura, formação e desenvolvimento profissional de professores que ensinam Matemática: investigando e teorizando a partir de prática. São Paulo: Musa Editora, 2005.

[13] Oliveira, S. C.; Gomes, C. F. Ludicidade e adolescência. Disponível em: http://www.psicopedagogia.com.br/opiniao/opiniao.asp?entrID=3. Acesso em 12 ago. 2008.

[14] Orlandi, E. P. Análise de Discurso: princípios e procedimentos. Campinas: Pontes, 2009.

[15] Pêcheux, M. Semântica e Discurso: uma crítica à afirmação do óbvio. Campinas, SP: Editora da UNICAMP, 2009.

[16] Piaget, J. Inteligencia y afectividad. Buenos Aires: Aique, 2005. 


\section{Capítulo 23}

\section{A trilha dos números: Explorando pistas e encontrando múltiplos}

\section{Moises da Silva Santos \\ Adriana de Souza Lira}

\section{Luria Thamires Brito da Costa}

Sinval de Oliveira

Resumo: No presente relato de experiência descreve-se uma ação que decorre de uma parceria entre o Colégio CAIC Jorge Humberto Camargo e o Núcleo do PIBID de Matemática, ambos situados no município de Araguaína - TO. A questão problematizadora foi expressa da seguinte forma: como os bolsistas poderiam desenvolver uma aula por meio de jogos? A metodologia utilizada se deu a partir do levantamento de jogos já conhecidos, de artigos, de reuniões de planejamento e de registros nos respectivos cadernos de campo. Como resultados, destacam-se: o processo de adaptação de um jogo, sua inserção na docência com a realização de atividades em espaços abertos, a identificação de dificuldades operacionais nos alunos participantes e a necessidade de se produzir elementos de avaliação de jogos no contexto das aulas de matemática.

Palavras-chave: PIBID; jogos; Adaptação; Matemática. 


\section{INTRODUÇÃO}

Este trabalho diz respeito a uma atividade realizada no Colégio CAIC Jorge Humberto Camargo, situado no município de Araguaína - TO, em parceria com o Núcleo PIBID de Matemática da Universidade Federal do Tocantins - Câmpus de Araguaína.

O componente curricular escolhido tratava sobre os conjuntos de múltiplos e divisores e foi desenvolvido com os alunos do sexto ano do Ensino Fundamental II. Este componente estava previsto no programa escolar para o corrente ano. Em linhas gerais, o desenvolvimento exigiu dos bolsistas, que figuram como autores deste trabalho, ações de planejamento em torno do tema que incluíram, entre outras coisas, a resolução de exercícios como forma de melhorar a compreensão da dimensão conceitual do conteúdo em pauta.

As discussões no âmbito da equipe de bolsistas e as orientações da professora supervisora e dos professores colaboradores direcionaram o trabalho para a elaboração de uma proposta didática que explorava a temática dos múltiplos por meio de adaptação dos tradicionais jogos de trilhas. Porém, a adaptação realizada pelos autores deste artigo e responsáveis pela organização e desenvolvimento da proposta redimensionou o tabuleiro tradicional de tal forma que, na nova arquitetura, o jogo poderia ser chamado de trilha humana, pois cada peça representante dos jogadores passou a ser interpretada por um aluno; a exemplo dos tabuleiros tradicionais, o aluno agora, era o avatar de sua equipe.

Na próxima seção, apresentamos alguns argumentos teóricos que corroboraram a nossa investida na elaboração e na aplicação da proposta.

\section{ALGUMAS REFLEXÕES TEÓRICAS}

Trabalhar com jogos nas aulas de matemática como meio didático é uma forma de desencadear no aluno a interação, tendo como foco a aprendizagem de objetos matemáticos. Muitos estudos afirmam que nas últimas décadas têm sido usados de forma válida os jogos nas práticas pedagógicas no ensino da matemática, mostrando sua importância no ato de educar. Entre as questões que validam os jogos como instrumento didático, Macedo (2015) argumenta que eles permitem:

Compreender melhor, fazer melhores antecipações, ser mais rápido, cometer menos erros ou errar por último, coordenar situações, ter condutas estratégicas etc. são chaves para o sucesso. Para ganhar é preciso ser habilidoso, estar atento, concentrado, ter boa memória, saber abstrair, relacionar as jogadas todo o tempo. (MACEDO, 2015, p.135).

0 jogo está intimamente ligado às nossas práticas socioculturais, permeando o dia-a-dia das crianças a partir dos primeiros meses de vida e, de forma semelhante, as relações matemáticas gravitam em torno de nossas ações cotidianas, sejam elas atividades laborais ou recreativas. Então, a partir da percepção da coexistência dos jogos e das relações matemáticas em torno das atividades diárias dos sujeitos é que decorre a possibilidade de projetar ações didáticas unindo os jogos aos conteúdos matemáticos.

A literatura que discute a importância dos jogos para o ensino, e em particular para o ensino e aprendizagem de objetos matemáticos, é ampla no campo da pesquisa da Educação Matemática, disciplina que se ocupa dessas interrelações. Por exemplo, as leituras e fichamentos no âmbito do Núcleo do PIBID de Matemática, a partir dos escritos de Macedo (2015) sobre "Os jogos e sua importância na escola", mostrou-nos que, frente à teoria de Piaget, a importância dos jogos com fim de desenvolver conteúdos, permitiu-nos destacar três pontos importantes sobre os jogos. São eles: jogos de exercícios em que a assimilação dos conteúdos se dá pela prática e repetições; jogos simbólicos, nos quais a fantasia e a forma lúdica despertam o interesse; jogos de regras, nos quais se desperta estratégias frente aos desafios do jogo.

Teixeira e Vaz (2001, p. 6) afirmam que "uma das situações mais eficazes para se conseguir o envolvimento das crianças para se poder apreciá-las mentalmente ligadas e acesas completamente envolvidas na atividade que realizam, ocorre quando esta atividade é um jogo". Com isso, percebemos que as reflexões teóricas sobre a utilização de jogos para o ensino e aprendizagem de matemática são positivas e viabilizam contribuições reais para a formação do aluno, tendo em vista os múltiplos instrumentos da cognição que eles mobilizam. Essas características iniciais permitiram-nos perseguir a tarefa de adaptação de um jogo de trilhas para o ensino e aprendizagem de matemática. 


\section{DESENVOLVIMENTO DO PROJETO}

Como início das atividades, uma equipe de bolsistas se pôs a pesquisar, por meio do uso da internet, jogos pedagógicos que pudessem se relacionar com a temática dos múltiplos e divisores, como forma de encontrarmos subsídios que nos permitissem reorganizá-los e adaptá-los para a temática que havíamos elegido. Obviamente que essa procura já manteve a preocupação de que as propostas identificadas estivessem em sintonia teórica com o que estávamos estudando. Porém, isso não significa dizer que o ideário seria um reducionismo teórico da aprendizagem para o fazer, o praticar e o repetir em detrimento da criatividade, da reflexão e da interação.

Visto isso, fizemos um planejamento e pesquisamos meios pelos quais pudéssemos perseguir um fazer pedagógico por meio de aulas que tivessem um componente prático e, nesse sentido, que os alunos pudessem experimentar uma aula diferente daquela considerada meramente expositiva e também partilhar seus conhecimentos. Daí decorre um ponto importante do nosso planejamento, quando consideramos a identificação de diferentes atividades para que a nossa pudesse ser estruturada, pois:

Um bom planejamento supõe uma definição clara de objetivos a serem alcançados. 0 estabelecimento de objetivos constitui uma base sólida para a seleção de conteúdo, métodos, técnicas, estratégias e recursos. (ROSA NETO, 1992, p. 39).

0 trabalho de busca por experiências didáticas, em sintonia com as nossas reflexões, proporcionou-nos a identificação da atividade "Encontre o número", publicada no caderno online do Plano de Desenvolvimento Educacional de 2013 do Paraná - Os Desafios da Escola Pública Paranaense na Perspectiva do Professor: Produções Didático Pedagógicas. Em linhas gerais, a atividade "Encontre o número" faz parte de um conjunto de publicações direcionadas à formação de professores que ensinam matemática no estado paranaense. No âmbito de alguns cadernos online que observamos, percebemos um cuidado descritivo com cada atividade, de tal forma que o professor, em contato com determinada proposta, sinta-se motivado para implementá-la em sala de aula. E, em parte, esse fato mobilizou a equipe de bolsistas a estudar a atividade "Encontre o número".

0 estudo da atividade levou a equipe de bolsistas à criação de um conjunto de materiais, como fichas, cartazes, coletes para os competidores e regras que permitiam a exploração de múltiplos e divisores. Nessa etapa, as discussões internas ponderaram sobre os riscos de promovermos adaptações ou alterações que pudessem comprometer o potencial didático da proposta. As imagens a seguir detalham parte desse processo de adaptação e construção.

Figura 01- Construção de Materiais: cartazes, fichas, coletes.
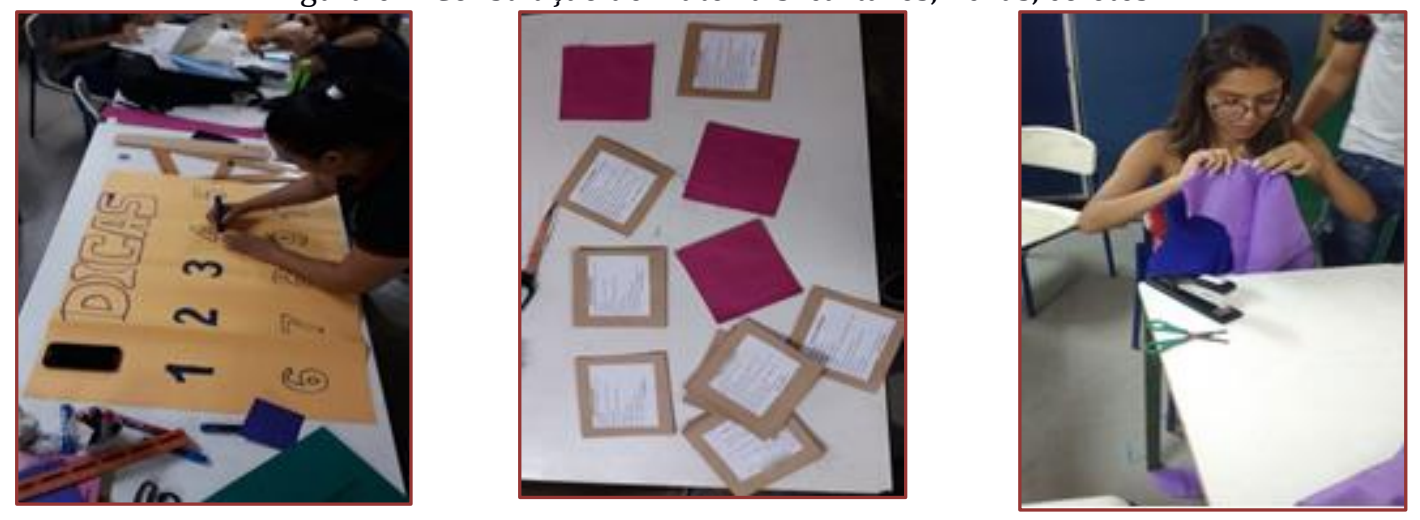

Fonte: PIBID/UFT/MATEMÁTICA/ARAGUAÍNA

Em termos das alterações implementadas em relação à proposta original do jogo, podemos dizer que o tabuleiro para a realização passou a ser os tatames que a escola dispunha e que eram usados pelos professores de educação física. 0 espaço físico para o jogo passou a ser a quadra da escola, ao invés da sala de aula, então os tatames serviram de trilha para os jogadores. 
As turmas passaram a ser divididas em três ou quatro equipes que elegiam um representante para se deslocar sobre o tabuleiro. Cada representante vestia um colete de cor diferente, e os membros das equipes usavam faixas coloridas, conforme a cor do colete dos respectivos representantes.

Uma característica importante do jogo original diz respeito às fichas. A função delas no jogo é apresentar informações na forma de pistas para que um número possa ser "encontrado". Nesse sentido, essa propriedade apresenta um leque de opções para o professor adaptar o jogo. Por exemplo, é possível construir fichas com pistas para se determinar múltiplos com dois, três ou mais algarismos, ou, ainda, múltiplos específicos, por exemplo, de cinco ou dez. Nesses casos, a nossa conclusão preliminar nos diz que o professor poderá adaptar as fichas para turmas dos anos iniciais do ensino fundamental, entre outras opções; ou seja, há um caráter versátil no jogo, o qual se dá por meio de suas fichas, e esse fato inspirou-nos na presente experiência, e explica em parte o título escolhido para a mesma: $A$ trilha dos números: explorando pistas e encontrando múltiplos. A imagem a seguir ilustra um modelo de ficha com pistas.

Figura 02- Exemplo de ficha com pistas.

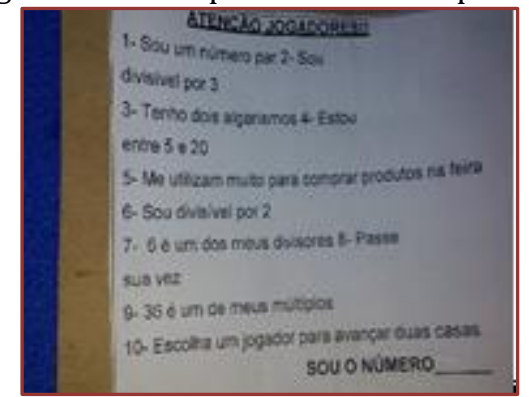

Fonte: PIBID/UFT/MATEMÁTICA/ARAGUAÍNA

A dinâmica do jogo é simples. Definem-se regras de início do jogo para duas situações que esclarecem a ordem de respostas entre as equipes e a ordem na qual as equipes enunciariam as pistas. Uma vez estabelecida essa organização, inicia-se o jogo, mantendo-se fixas essas ordens. Suponha então quatro equipes $A, B, C$ e $D$ com a seguinte organização de enunciação de pistas: $A \rightarrow B \rightarrow C \rightarrow D$. Isto significa que o competidor da equipe $A$ será o primeiro a realizar a leitura das pistas.

Vamos supor também que a ordem das respostas das equipes tenha ficado determinada por: $\rightarrow B \rightarrow C \rightarrow$ $D \rightarrow A$. Nessa hipótese, o competidor da equipe $B$ é o primeiro que solicitará uma pista da ficha que estiver em jogo. 0 competidor poderá ser auxiliado pelos demais membros da sua equipe para desvelar a pista que escolheu.

De maneira geral, o deslocamento de um competidor sobre a trilha dependerá da forma como essa regra for definida. Na atual versão do jogo, definiu-se a seguinte norma: desloca-se sempre em cada rodada o número de pistas não utilizadas na rodada. Como as fichas apresentam de forma fixa 10 pistas, é simples o deslocamento. Na hipótese de a equipe não acertar uma pista na sua vez, a próxima equipe da sequência fará a sua solicitação de pista. Se na rodada todas as equipes não descobrirem o múltiplo, então o competidor da equipe que está fazendo a anunciação das pistas fará um deslocamento de dez unidades na trilha.

A estrutura das pistas nas fichas também pode conter aquelas situações que tornam o jogo desafiador e emocionante, como por exemplo, pistas que fazem perder a vez, ou causar deslocamento em jogadores de outras equipes. De forma semelhante, também, cada equipe poderá ter cartas "coringa", que permitam responder uma dica antes do competidor que está na vez. Em linhas gerais, essas situações podem conter regras diversas para interferir na dinâmica do jogo. A nossa experiência, nesse caso em particular, é que essas situações foram aceitas com naturalidade no decorrer do jogo.

\section{A EXPERIÊNCIA E OS RESULTADOS INICIAIS}

Conforme planejamos, dirigimo-nos com a turma para a quadra da escola. Previamente, já havíamos organizado os tatames na forma de trilha para o desenvolvimento da atividade. Dividimos as equipes e explicamos as regras previamente. Alguns materiais foram observados individualmente pelos alunos, como por exemplo, as fichas, porém ainda não havia se configurado a situação de jogo entre as equipes. 
Esse contato inicial dos alunos com os materiais serviu para eles satisfazerem uma curiosidade imediata de exploração.

Como resultados iniciais da aplicação do jogo em duas turmas do sexto ano, identificamos por meio de observação que houve participação e envolvimento dos alunos. Eles demonstravam expectativas sobre a leitura das pistas e as situações de jogo que ocorriam durante a dinâmica. A agitação dos alunos em torno das respostas foi maior do que esperávamos. Percebemos momentos de interação e de discussão entre eles para inferirem alguma resposta.

Identificamos algumas dificuldades no decorrer do processo. Por exemplo, os membros das equipes que atuavam como jogadores apresentaram dificuldades de interpretação das pistas. Inicialmente, não estabeleciam correlações entre as informações que eram lidas. Por sua vez, alguns competidores, quando atuavam na função de enunciação de pistas, não apresentavam uma leitura fluente das pistas. Não é possível inferir conclusões sobre esses aspectos observados. Por exemplo, no caso da leitura, a situação de leitura em público, mesmo que entre colegas de classe, pode estar relacionada a questões de foro íntimo, ou seja, os sujeitos poderiam ser introvertidos.

Já com relação às dificuldades em matemática, a situação de jogo, ou seja, as expectativas, as múltiplas falas dos colegas de equipe também podem influenciar na avaliação dessas dificuldades que observamos. As imagens a seguir apresentam, respectivamente, o momento inicial de orientação e o momento da situação de jogo, em que as equipes estão posicionadas no tabuleiro.

Figura 03- Orientações iniciais

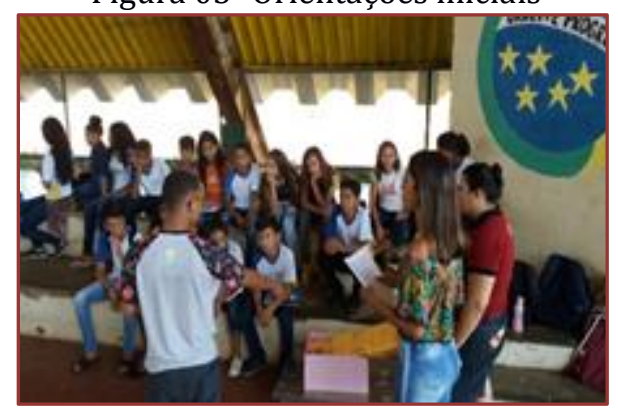

Figura 04- Situação de jogo

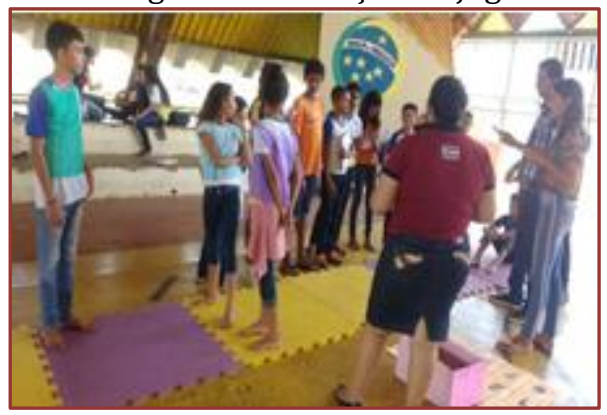

Fonte: PIBID/UFT/MATEMÁTICA/ARAGUAÍNA

\section{CONSIDERAÇÕES FINAIS}

A experiência em torno da adaptação e do desenvolvimento do jogo que denominamos "A trilha dos números: explorando pistas e encontrando múltiplos" produziu nos bolsistas algumas reflexões que podem ser organizadas em duas categorias. A primeira delas concerne aos alunos que participaram da atividade proposta, e a segunda diz respeito à formação profissional dos bolsistas.

Com relação aos alunos da escola que participaram da atividade, as nossas observações no decorrer do desenvolvimento permitiram identificar que as situações propostas no decorrer do jogo desencadearam atitudes que se manifestaram por meio da participação, do interesse, da discussão, do envolvimento e da situação de competitividade que o contexto produziu. Nesse sentido, sentimos a necessidade de uma continuidade de ações semelhantes para se produzir instrumentos mais precisos de avaliação desses resultados.

Com relação aos bolsistas do Núcleo do PIBID de Matemática que participaram ativamente desse processo, a experiência marcou o início das respectivas formações por meio de uma confluência entre questões que marcam o ofício da docência. Essas marcas advieram da necessidade de desenvolvimento de ações pautadas por planejamento; da possibilidade de produzir adaptações didáticas a partir de outras experiências; da realização de aulas que não se deram no espaço convencional da sala de aula e da interação com os alunos a partir de uma situação contextual de natureza dinâmica e com possibilidades reais de contribuições para a formação matemática dos alunos da escola. 
Percebemos então que o PIBID, na forma que vem se constituindo e articulando com as unidades de ensino participantes do programa, configura-se, em outras interpretações, em um espaço de aprendizagem para a formação inicial de professores de matemática, a partir de contextos que demandam aos bolsistas o desenvolvimento de ações didáticas interconectadas com muitas das perspectivas descritas nos planos de intervenções dessas unidades. Nesse sentido, parece-nos que há uma via de mão dupla se estabelecendo em torno dos projetos e ações desenvolvidas no âmbito do Núcleo do PIBID de Matemática, uma vez que, ao mesmo tempo em que, os bolsistas contribuem para com algumas demandas previstas nos PPPs, também são afetados por elas tendo em vista o aprendizado no campo da docência que o contexto das ações propiciaram.

\section{AGRADECIMENTOS}

Agradecemos à Coordenação de Aperfeiçoamento de Pessoal de Nível Superior (CAPES), agência de fomento do programa PIBID. Aos professores de matemática do Colégio CAIC, em especial ao professor Luan Alves Ferreira, pelo apoio e compartilhamento de conhecimentos sobre sua trajetória como exbolsista e sobre sua presente atuação profissional na escola.

\section{REFERÊNCIAS}

[1] Macedo, R. S. Pesquisar a experiência: compreender/medir saberes experienciais. Curitiba: CRV, 2015.

[2] Rosa Neto, E. Didática da matemática. 4aa ed. São Paulo: Ática, 1992.

[3] Teixeira, S. F. A; Vaz, M. O. Jogos matemáticos. Goiânia: Gev, 2001. 


\section{Capítulo 24}

\section{A formação de educadores e as concepções sobre resolução de problemas no ensino de Matemática}

\section{Jéssica Tomiko Araújo Mitsuuchi}

Tania Teresinha Bruns Zimer

Resumo: As discussões aqui apresentadas referem-se a um recorte do Trabalho de Conclusão de Curso de Pedagogia, da Universidade Federal do Paraná, que teve como objetivo compreender quais são as concepções dos educadores em Formação Inicial sobre a Resolução de Problemas no ensino de Matemática, sendo os sujeitos da pesquisa estudantes da $3^{\mathfrak{a}}$ série do Curso de Formação de Docentes, de uma instituição pública de Curitiba. A metodologia de pesquisa adotada refere-se à abordagem qualitativa, em consonância com as ideias de Bogdan e Biklen (1994), utilizando como instrumentos de coleta de dados um questionário e entrevista. As reflexões e análises da pesquisa de campo, à luz das perspectivas de Polya (2006), Onuchic e Allevato (2004; 2014) e Smole e Diniz (2001) sobre Resolução de Problemas, evidenciam uma fase de transição entre o pensamento tradicional e a adoção de novas estratégias no ensino-aprendizagem em Matemática, como a Resolução de Problemas, presentes indiretamente nas falas dos sujeitos.

Palavras-chave: Resolução de Problemas; Formação de Educadores; Concepções; Ensino de Matemática. 


\section{INTRODUÇÃO}

No ensino da Matemática, é vasta a literatura que aponta a Resolução de Problemas como um dos principais princípios para nortear a prática pedagógica do professor (ONUCHIC e ALLEVATO, 2014; SMOLE e DINIZ, 2002; POLYA, 2006, entre outros). Entretanto, as diferentes práticas de ensino pautadas na Resolução de Problemas evidenciam vários modos de concebê-la, pois parte-se da hipótese de que a maneira como se concebe um conceito se reflete na prática em sala de aula. Nesse contexto, as discussões aqui apresentadas referem-se a um recorte do Trabalho de Conclusão de Curso de Pedagogia, da Universidade Federal do Paraná (UFPR), intitulado "Concepções acerca da Resolução de Problemas Matemáticos: A formação inicial do Educador em evidência" (MITSUUCHI, 2018), que teve como objetivo geral compreender as concepções apresentadas por educadores em formação inicial da Educação Infantil e dos Anos Iniciais sobre Resolução de Problemas no ensino de Matemática. A intenção da pesquisa decorre da necessidade de refletir sobre a formação do docente no que tange às concepções e aplicações da Resolução de Problemas, atrelando tais inquietações às experiências do campo de Estágio Supervisionado em Gestão e Organização Escolar em uma instituição de ensino que oferta o Curso de Formação de Docentes, na modalidade Normal (Ensino Médio Integrado). Desse modo, ressalta-se a preocupação com a formação do Educador, pois é este o profissional que poderá iniciar o trabalho com a Resolução de Problemas com os estudantes na Educação Infantil.

Sendo assim, firmam-se como objetivos para este artigo apresentar os dados coletados no campo de pesquisa e relacionar os resultados obtidos com autores que discutem as diferentes concepções sobre Resolução de Problemas no ensino de Matemática (ONUCHIC; ALLEVATO, 2014; SMOLE; DINIZ, 2001; POLYA, 2006, entre outros).

O campo de pesquisa diz respeito a uma instituição estadual de ensino público, localizada na região central de Curitiba. Conforme apresentado no Regimento Escolar da instituição, a oferta do Curso de Formação de Docentes, em nível médio, na modalidade Normal, habilita o estudante para a atuação na Educação Infantil e nos Anos Iniciais do Ensino Fundamental, sendo o concluinte considerado docente destas etapas supracitadas. Como foco da pesquisa, a Disciplina de Metodologia do Ensino da Matemática é ofertada na 3a série do Curso de Formação de Docentes com uma carga horária de oitenta horas letivas, distribuídas em duas horas aulas semanais. Os pressupostos teóricos que norteiam a disciplina consideram a integração entre a teoria e a prática, visando a formação de uma consciência crítico-social voltada para os objetivos do curso.

Para a delimitação dos sujeitos da pesquisa, considerando a quantidade de estudantes das $3^{\text {a }}$ séries do Curso de Formação de Docentes matriculados na disciplina de Metodologia do Ensino de Matemática (aproximadamente oitenta estudantes), elegeram-se nove estudantes oriundos das três turmas (A, B e C), escolhidos de modo aleatório a partir do preenchimento de um questionário inicial. Com o intuito de preservar a identidade dos estudantes, os sujeitos da pesquisa serão identificados pela letra "E", seguidos pelos numerais de 1 a 9 (E1, por exemplo), sem a distinção de gênero. A faixa etária destes sujeitos varia entre 16 a 20 anos.

\section{ASPECTOS METODOLÓGICOS}

Ainda que a pesquisa seja identificada como qualitativa, Bogdan e Biklen (1994) salientam o emprego conjunto das abordagens qualitativa e quantitativa como a comum prática de utilização de questionários para entrevistas abertas e, posteriormente, a realização de observações em profundidade "para descobrir por que é que duas variáveis estão estatisticamente relacionadas" (p. 63). Assim, para a presente pesquisa, como instrumento de coleta de dados inicial foi elaborado um questionário com uma questão aberta e uma parte em escala tipo Likert. A opção por este modelo decorre de fatores como a grande quantidade de alunos matriculados na disciplina de Metodologia do Ensino da Matemática, a formulação própria da conceituação de Resolução de Problemas, a identificação das concepções mais recorrentes e a verificação da presença de uma fase de estruturação do pensamento do aluno, uma vez que a escala Likert fornece direções sobre o posicionamento do respondente em cada afirmativa, além da simplicidade de aplicação (BERMUDES et al., 2016).

Para tanto, as afirmativas foram organizadas a partir de correntes de pensamento sobre Resolução de Problemas no ensino de Matemática, como a Metodologia de Ensino-Aprendizagem-Avaliação de Matemática através da Resolução de Problemas, proposta por Onuchic e Allevato (2014), a Perspectiva Metodológica de Resolução de Problemas, por Smole e Diniz (2001), e a Heurística, de Polya (2006). 
A primeira concepção integra a aprendizagem e a avaliação de modo simultâneo "durante a construção do conhecimento pelo aluno, com o professor atuando como guia e mediador" (ONUCHIC; ALLEVATO, 2014, p. 43); a segunda, diz respeito à "uma forma de organizar o ensino que envolve mais que aspectos puramente metodológicos, incluindo toda uma concepção frente ao que é ensinar e, consequentemente, do que significa aprender, e uma compreensão de por que ensinar matemática" (SMOLE; DINIZ, 2016, p. 11); e por último, refere-se à utilização de passos essenciais de como resolver um problema, definidos como a compreensão do problema, o estabelecimento de um plano, a execução do plano e o retrospecto, além da ideia constante de preparação do professor para as respostas e reações dos alunos, visando a mediação efetiva para a resolução do problema (POLYA, 2006).

O questionário pode ser observado na FIGURA 1:

Figura 1 - Questionário inicial

\begin{tabular}{|c|c|c|c|}
\hline \multirow{2}{*}{\multicolumn{4}{|c|}{$\begin{array}{l}\text { RESOLUÇÃO DE PROBLEMAS NO ENSINO DE MATEMÁTICA } \\
\text { Iniciais do nome: } \frac{\text { Idade: }}{\text { O que você compreende por Resolução de Problemas no ensino de Matemática? }} \\
\text { Considere as afirmativas e assinale a alternativa na escala que mais se aproxima de sua opinião: }\end{array}$}} \\
\hline & & & \\
\hline AFIRMATIVAS & Concordo & $\begin{array}{l}\text { Nem concordo e } \\
\text { nem discordo }\end{array}$ & Discordo \\
\hline \multicolumn{4}{|l|}{$\begin{array}{l}\text { 1. A Resolução de Problemas é um tipo de exercício de aplicação/fixação do } \\
\text { conhecimento matemático. }\end{array}$} \\
\hline \multicolumn{4}{|l|}{$\begin{array}{l}\text { 2. A Resolução de Problemas é uma maneira de dar início a um conteúdo } \\
\text { (contextualização). }\end{array}$} \\
\hline \multicolumn{4}{|l|}{$\begin{array}{l}\text { 3. A Resolução de Problemas é uma consequência do saber matemático (o que } \\
\text { realmente importa é o conhecimento da Matemática, não o problema). }\end{array}$} \\
\hline \multicolumn{4}{|l|}{$\begin{array}{l}\text { 4. Na Resolução de Problemas o objetivo é apenas encontrar o resultado } \\
\text { correto. }\end{array}$} \\
\hline \multicolumn{4}{|l|}{$\begin{array}{l}\text { 5. Na Resolução de Problemas, existe apenas uma estratégia válida para chegar } \\
\text { ao resultado esperado. }\end{array}$} \\
\hline \multicolumn{4}{|l|}{$\begin{array}{l}\text { 6. A Resolução de Problemas pode acompanhar todo o processo (ensino, } \\
\text { aprendizagem e avaliação). }\end{array}$} \\
\hline \multicolumn{4}{|l|}{$\begin{array}{l}\text { 7. A Resolução de Problemas compreende o que é ensinar, o que significa } \\
\text { aprender e o porquê de ensinar Matemática. }\end{array}$} \\
\hline \multicolumn{4}{|l|}{ 8. Na Resolução de Problemas, o professor necessita de constante preparação. } \\
\hline \multicolumn{4}{|l|}{$\begin{array}{l}\text { 9. O professor é o centro do processo, sendo ele o detentor de todo e único } \\
\text { conhecimento. }\end{array}$} \\
\hline \multicolumn{4}{|l|}{$\begin{array}{l}\text { 10. } 0 \text { professor age como mediador na Resolução de Problemas, auxiliando o } \\
\text { estudante a encontrar soluções e estratégias. }\end{array}$} \\
\hline \multicolumn{4}{|l|}{ 11. 0 estudante pode resolver os problemas propostos em grupo. } \\
\hline $\begin{array}{l}\text { 12. O conhecimento prévio do estudante não é levando em consideração na } \\
\text { Resolução de Problemas }\end{array}$ & & & \\
\hline
\end{tabular}

Fonte: As autoras.

O objetivo deste questionário refere-se ao contato inicial com as concepções dos sujeitos da pesquisa sobre a Resolução de Problemas no ensino de Matemática. A aplicação do mesmo ocorreu durante as aulas de Metodologia do Ensino da Matemática nas turmas de $3^{\circ}$ séries do Curso de Formação de Docentes. No entanto, apesar do total de cinquenta questionários respondidos, houve uma pequena defasagem de potenciais participantes da pesquisa (cerca de trinta alunos), uma vez que a realização do questionário foi 
feita na última semana do primeiro semestre letivo. A escolha do momento surgiu em conversa com a docente responsável pela disciplina, que planejou o conteúdo de Resolução de Problemas para as primeiras semanas após o recesso escolar de julho. Logo, teve-se a ideia de analisar as concepções antes das intervenções propriamente ditas sobre o conteúdo em questão, acompanhar as discussões em sala de aula e, por fim, averiguar possíveis mudanças de concepções depois da aprendizagem formal sobre Resolução de Problemas.

Do mesmo modo, a realização das entrevistas como meio de coleta de dados permitiu penetrar nas considerações acerca das concepções dos educadores em Formação Inicial sobre a Resolução de Problemas no ensino de Matemática. Bogdan e Biklen (1994, p. 134) justificam que, “[...], a entrevista é utilizada para recolher dados descritivos na linguagem do próprio sujeito, permitindo ao investigador desenvolver intuitivamente uma ideia sobre a maneira como os sujeitos interpretam aspectos do mundo". Neste sentido, a função da entrevista é aprofundar os dados coletados pelo questionário e pelas observações, articulando os diferentes instrumentos e otimizando os resultados.

As entrevistas foram realizadas de acordo com o horário das aulas de Metodologia do Ensino de Matemática em cada turma, com o consentimento da docente responsável pela disciplina. 0 roteiro para a entrevista, assim como a pretensão de cada pergunta, destacada em itálico, pode ser observado na FIGURA 2:

Figura 2 - Roteiro de entrevista

\section{ROTEIRO DE ENTREVISTA}

1. Por que escolheu o Curso de Formação de Docentes? Considerar as influências e as possibilidades de continuar na profissão.

2. Como você avalia as disciplinas do Curso? Parecer crítico do curso.

3. O que você considera como Matemática? Analisar a compreensão sobre a Matemática de modo geral.

4. Como você se relaciona com a Matemática? Observar as relações afetivas/cognitivas com a Matemática escolar.

5. Exemplos de situações suas com a Matemática no ambiente escolar. Possibilidade de relacionar experiências pessoais com a formação de conceitos matemáticos

6. Qual era sua expectativa para a disciplina de Metodologia do Ensino de Matemática? Observar as expectativas de aprendizagem.

7. $\quad 0$ que você considera como Resolução de Problemas, depois de ter estudado sobre? Comparar e aprofundar as afirmativas propostas no questionário.

8. 0 que foi mais significativo para você neste conteúdo?Verificar a construção real do conhecimento.

9. $\quad 0$ que e/ou quem você considera ter contribuído para essa situação? Parecer crítico da disciplina.

10. Você se considera apto/capaz de trabalhar com a Resolução de Problemas no ensino de Matemática na Educação Infantil e nos Anos Iniciais? Por quê? Parecer crítico do estudante.

11. Como você conduziria uma aula com a Resolução de Problemas? Analisar a postura docente do estudante e a possível aplicação/utilização da Resolução de Problemas.

12. Gostaria de falar algo mais sobre Resolução de Problemas, sua ação como futuro docente, sua formação para ensinar matemática? Perspectiva educacional do estudante.

Fonte: As autoras.

Antes do início de cada entrevista, eram apresentadas brevemente as perguntas e explicado que não havia respostas certas ou erradas. Ainda, a fim de registro, também foi utilizado o gravador de áudio com a permissão dos estudantes e a respectiva concordância de participação na pesquisa.

\subsection{DESCRIÇÃO E ANÁLISE DOS DADOS}

A forma de análise da presente pesquisa visa articular os instrumentos de coleta de dados, tomando como ponto de partida a realização do questionário inicial. A realização do questionário foi de grande importância para a investigação sobre as concepções acerca da Resolução de Problemas no ensino de Matemática, tendo em vista que os estudantes ainda não haviam estudado formalmente a respeito. Logo, 
as respostas obtidas neste questionário representam a ideia que os estudantes construíram ao longo de sua vida escolar até o contato com o conteúdo propriamente dito.

Consoante com o que foi dito anteriormente, as afirmativas foram escolhidas a partir das correntes de pensamento sobre Resolução de Problemas no ensino de Matemática, como a Heurística de Polya (2006), a Perspectiva Metodológica de Resolução de Problemas, por Smole e Diniz (2001), e a Metodologia de Ensino-Aprendizagem-Avaliação de Matemática através da Resolução de Problemas, proposta por Onuchic e Allevato (2014). Por apresentarem semelhanças no modo de conceber a Resolução de Problemas, em algumas afirmativas (1, 9 e 12) foi considerado como correspondente a Perspectiva Metodológica de Resolução de Problemas, ao Ensino-Aprendizagem-Avaliação de Matemática através da Resolução de Problemas e a Heurística, de modo simultâneo. No entanto, sabendo que as demais afirmativas também podem corresponder da mesma forma a mais de uma perspectiva, considerou-se apenas a que apresenta como parte essencial de sua concepção, à exemplo da afirmativa 6, que expressa "A Resolução de Problemas pode acompanhar todo o processo (ensino, aprendizagem e avaliação)" e que diz respeito ao Ensino-Aprendizagem-Avaliação de Matemática através da Resolução de Problemas.

No QUADRO 2, as respostas dos sujeitos de pesquisa foram tabuladas com o intuito de perceber a predominância de concepções que os estudantes apresentaram no questionário inicial:

Quadro 2 - Afirmativas sobre Resolução de Problemas

\begin{tabular}{|c|c|c|c|}
\hline AFIRMATIVAS & Concordo & $\begin{array}{c}\text { Nem } \\
\text { concordo e } \\
\text { nem discordo }\end{array}$ & Discordo \\
\hline $\begin{array}{l}\text { 1. A Resolução de Problemas é um tipo de exercício de aplicação/fixação do } \\
\text { conhecimento matemático. }\end{array}$ & 8 & 1 & 0 \\
\hline $\begin{array}{l}\text { 2. A Resolução de Problemas é uma maneira de dar início a um conteúdo } \\
\text { (contextualização). }\end{array}$ & 2 & 6 & 1 \\
\hline $\begin{array}{l}\text { 3. A Resolução de Problemas é uma consequência do saber matemático (o que } \\
\text { realmente importa é o conhecimento da Matemática, não o problema). }\end{array}$ & 3 & 2 & 3 \\
\hline $\begin{array}{l}\text { 4. Na Resolução de Problemas o objetivo é apenas encontrar o resultado } \\
\text { correto. }\end{array}$ & 2 & 2 & 5 \\
\hline $\begin{array}{l}\text { 5. Na Resolução de Problemas, existe apenas uma estratégia válida para } \\
\text { chegar ao resultado esperado. }\end{array}$ & 1 & 2 & 6 \\
\hline $\begin{array}{l}\text { 6. A Resolução de Problemas pode acompanhar todo o processo (ensino, } \\
\text { aprendizagem e avaliação). }\end{array}$ & 7 & 2 & 0 \\
\hline $\begin{array}{l}\text { 7. A Resolução de Problemas compreende o que é ensinar, o que significa } \\
\text { aprender e o porquê de ensinar Matemática. }\end{array}$ & 6 & 3 & 0 \\
\hline 8. Na Resolução de Problemas, o professor necessita de constante preparação. & 6 & 3 & 0 \\
\hline $\begin{array}{l}\text { 9. O professor é o centro do processo, sendo ele o detentor de todo e único } \\
\text { conhecimento. }\end{array}$ & 2 & $3^{26}$ & 5 \\
\hline $\begin{array}{l}\text { 10. O professor age como mediador na Resolução de Problemas, auxiliando o } \\
\text { estudante a encontrar soluções e estratégias. }\end{array}$ & 8 & 1 & 0 \\
\hline 11. 0 estudante pode resolver os problemas propostos em grupo. & 7 & 2 & 0 \\
\hline $\begin{array}{l}\text { 12. O conhecimento prévio do estudante não é levado em consideração na } \\
\text { Resolução de Problemas }\end{array}$ & 2 & 3 & 4 \\
\hline
\end{tabular}

Fonte: Dados de campo (2018).

A fase de instabilidade na formação da concepção, indicando a estruturação do pensamento do estudante, foi representada pela alternativa "Nem concordo e nem discordo", com trinta sinalizações. Observa-se que

260 estudante E7 assinalou, nesta afirmativa, as opções "Nem concordo e nem discordo" e "Discordo". A fim da contabilização das respostas, serão sinalizadas ambas, uma vez que esta questão irá aparecer durante a realização da entrevista. 
em algumas afirmativas, ora esta fase se sobressai em relação às alternativas que indicam um posicionamento formado, como a afirmativa 2, ora se aproxima das demais, como a afirmativa 12. Durante a realização das entrevistas, os estudantes do Curso de Formação de Docentes justificaram que a Resolução de Problemas pode ser uma maneira de dar início ao conteúdo, mas não necessariamente e/ou obrigatoriamente, assim como o conhecimento prévio do estudante pode ser levado em consideração ou não pelo professor. Ainda, alguns sujeitos da pesquisa mudaram de grau de concordância após o trabalho com Resolução de Problemas na disciplina (três estudantes passaram a concordar com a afirmativa 2, e 4 discordam da afirmativa 12). A análise feita a partir destes dados refere-se à ocorrência das concepções acerca da Resolução de Problemas. Para tal, elaborou-se o seguinte gráfico (GRÁFICO 1):

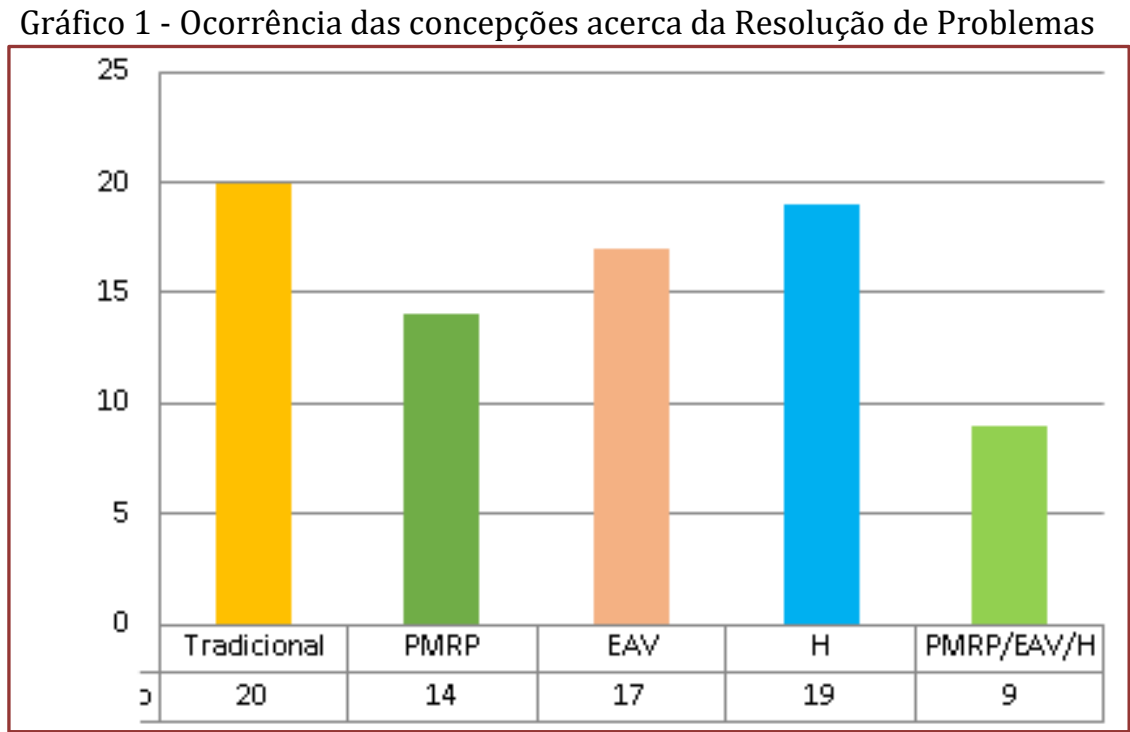

Fonte: Dados de campo (2018).

O GRÁFICO 1, em conjunto com o QUADRO 2, demonstra a variação na formação da concepção dos estudantes, tendo em vista que apresentam aspectos do pensamento tradicional, como compreender que a Resolução de Problemas é um tipo de exercício de aplicação/fixação do conhecimento matemático (Afirmativa 1), mas também se aproximam do pensamento que visa um ensino-aprendizagem significativo, conforme expressa a afirmativa 7 (A Resolução de Problemas compreende o que é ensinar, o que significa aprender e o porquê de ensinar Matemática). 0 que podemos notar, ainda, é a maior incidência das correntes de pensamento sobre Resolução de Problemas no ensino de Matemática (Polya, 2006; Smole e Diniz, 2001; Onuchic e Allevato, 2014), que corresponde à aproximadamente 74,68\% das sinalizações de concordância, em detrimento à perspectiva tradicional (25,32\% de concordância) ${ }^{27}$.

Apesar das respostas das afirmativas demonstrarem que os alunos do Curso de Formação de Docentes já possuem certo conhecimento ${ }^{28}$ acerca das perspectivas "modernas" de Resolução de Problemas, esse fator é quase imperceptível na discursiva da questão aberta, observando a brevidade das respostas e da pouca argumentação sobre as concepções, além da ocorrência de contradições entre os posicionamentos (questão aberta x afirmativas), salientando ainda mais a fase de instabilidade na estruturação da concepção do aluno. Como exemplos, seguem abaixo a transcrição de algumas das respostas dadas à questão aberta ("O que você compreende por Resolução de Problemas no ensino de Matemática?") e que demonstram tender para a perspectiva tradicional:

E1: Uma forma de responder perguntas feitas para achar a resposta de uma situação.

\footnotetext{
27 Para estes valores, foram apenas consideradas as sinalizações nas colunas "Concordo" e "Discordo" que totalizam 79 respostas.

${ }^{28}$ Este conhecimento pode ser considerado de senso comum, uma vez que o questionário foi aplicado antes do conteúdo sobre Resolução de Problemas no ensino de Matemática ser abordado formalmente. Outra perspectiva que justifica a aproximação das respostas às correntes de pensamento pode ser as novas compreensões sobre o processo de ensino-aprendizagem, que tornam o professor como mediador e auxiliador do aluno, que se destaca como protagonista da sua própria construção do conhecimento e, assim, contemplando também a área do ensino de Matemática.
} 
E5: Aprender a resolver exercícios de cálculo.

E8: Acredito que é uma [forma] de fixar a matéria/conteúdo dado.

(Trechos da entrevista feita com os estudantes participantes da pesquisa, 2018).

No que pode ser considerado como uma transição entre concepções, podemos considerar as seguintes respostas:

E2: Encontrar alternativas para trabalhar melhor o desenvolvimento matemático.

E6: Apresentação de problemas, muitas vezes cotidianos, que são resolvidos a partir de contas matemáticas para prática e/ou aplicação da matemática para melhor fixação.

(Trechos da entrevista feita com os estudantes participantes da pesquisa, 2018).

Nesta última transcrição, observa-se que o sujeito E6 expressa a relação da Resolução de Problemas com o cotidiano, mas a considera como parte da aplicação e fixação da Matemática.

Durante as entrevistas, as afirmativas foram retomadas com o intuito de verificar se houveram modificações (ou não) no modo de conceber a Resolução de Problemas no ensino de Matemática, além de aprofundar em como os estudantes compreendem cada afirmativa. Para tanto, elaborou-se o QUADRO 3:

3 - Retorno das afirmativas após o conteúdo de Resolução de Problemas

\begin{tabular}{|c|c|c|c|}
\hline AFIRMATIVAS & Concordo & $\begin{array}{l}\text { Nem concordo e } \\
\text { nem discordo }\end{array}$ & Discordo \\
\hline $\begin{array}{l}\text { 1. A Resolução de Problemas é um tipo de exercício de } \\
\text { aplicação/fixação do conhecimento matemático. }\end{array}$ & 6 & 3 & 0 \\
\hline $\begin{array}{l}\text { 2. A Resolução de Problemas é uma maneira de dar início a um } \\
\text { conteúdo (contextualização). }\end{array}$ & 5 & 4 & 0 \\
\hline $\begin{array}{l}\text { 3. A Resolução de Problemas é uma consequência do saber matemático } \\
\text { (o que realmente importa é o conhecimento da Matemática, não o } \\
\text { problema). }\end{array}$ & 2 & 3 & 4 \\
\hline $\begin{array}{l}\text { 4. Na Resolução de Problemas o objetivo é apenas encontrar o } \\
\text { resultado correto. }\end{array}$ & 1 & 0 & 8 \\
\hline $\begin{array}{l}\text { 5. Na Resolução de Problemas, existe apenas uma estratégia válida para } \\
\text { chegar ao resultado esperado. }\end{array}$ & 1 & 0 & 8 \\
\hline $\begin{array}{l}\text { 6. A Resolução de Problemas pode acompanhar todo o processo } \\
\text { (ensino, aprendizagem e avaliação) }\end{array}$ & 8 & 1 & 0 \\
\hline $\begin{array}{l}\text { 7. A Resolução de Problemas compreende o que é ensinar, o que } \\
\text { significa aprender e o porquê de ensinar Matemática. }\end{array}$ & 8 & 1 & 0 \\
\hline $\begin{array}{l}\text { 8. Na Resolução de Problemas, o professor necessita de constante } \\
\text { preparação. }\end{array}$ & 9 & 0 & 0 \\
\hline $\begin{array}{l}\text { 9. O professor é o centro do processo, sendo ele o detentor de todo e } \\
\text { único conhecimento. }\end{array}$ & 1 & 2 & 6 \\
\hline $\begin{array}{l}\text { 10. O professor age como mediador na Resolução de Problemas, } \\
\text { auxiliando o estudante a encontrar soluções e estratégias. }\end{array}$ & 9 & 0 & 0 \\
\hline 11. 0 estudante pode resolver os problemas propostos em grupo. & 9 & 0 & 0 \\
\hline $\begin{array}{l}\text { 12. O conhecimento prévio do estudante não é levado em consideração } \\
\text { na Resolução de Problemas }\end{array}$ & 0 & 0 & 9 \\
\hline
\end{tabular}


Com este quadro, é possível perceber que a coluna que representa a fase de estruturação do pensamento do estudante ("Nem concordo e nem discordo") demonstra uma queda nas sinalizações, representando cerca de 12,97\% das respostas totais. Assim, compreende-se que houve a influência do conteúdo/conhecimento formal na formação das concepções dos sujeitos da pesquisa em relação à Resolução de Problemas. Outro dado que complementa esta constatação é o aumento da concordância com as afirmativas relacionadas com a Perspectiva Metodológica de Resolução de Problemas, o EnsinoAprendizagem-Avaliação de Matemática através da Resolução de Problemas e a Heurística, totalizando 81 sinalizações.

O GRÁFICO 2 apresenta as alterações em relação à ocorrência das concepções acerca da Resolução de Problemas, contrastando as respostas obtidas no questionário e durante a entrevista:

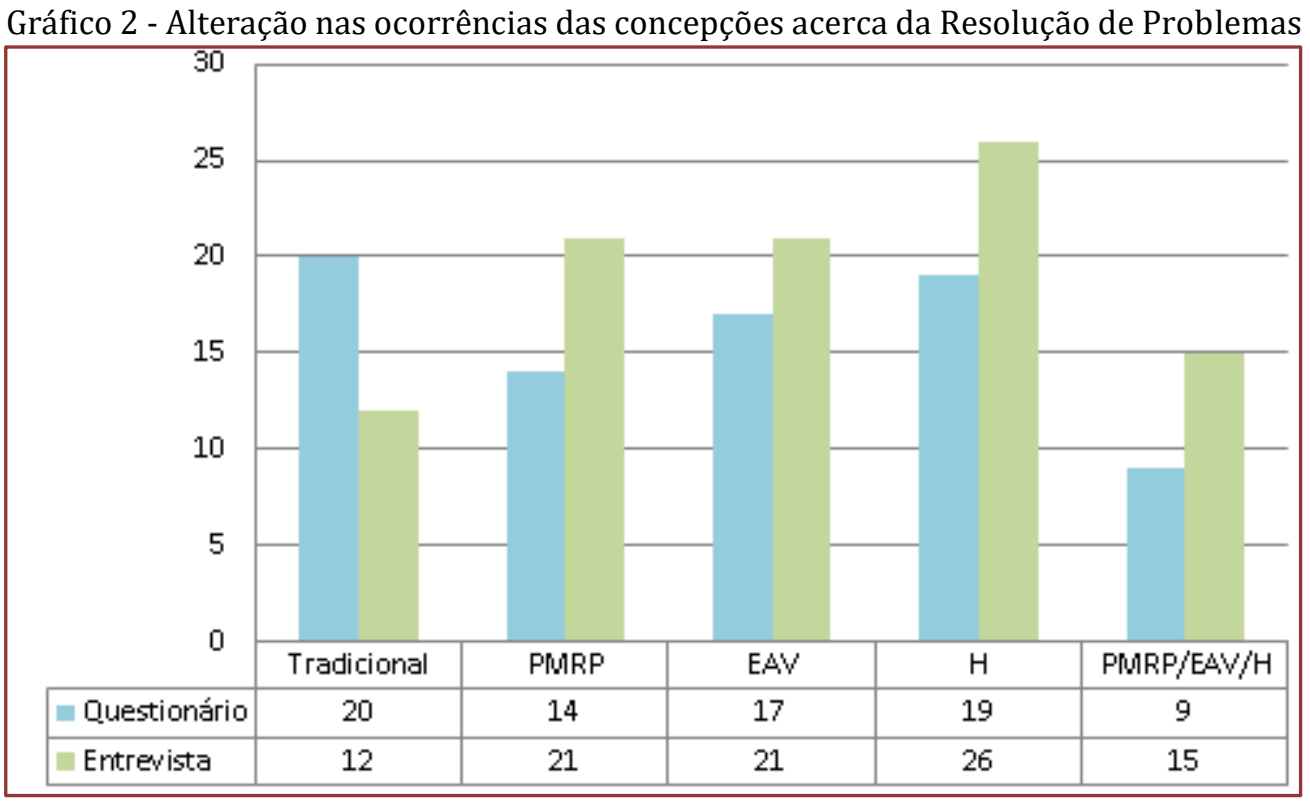

Fonte: Dados de campo (2018).

Do mesmo modo, em relação à questão aberta, a maioria dos sujeitos manteve seu discurso inicial acerca da Resolução de Problemas, apenas fazendo complementações no que tange às diferentes formas de ensinar e de resolver problemas, destacando também a aprendizagem da criança e as relações com o cotidiano. Um exemplo pode ser observado a seguir, retirado da transcrição da entrevista do estudante E6, como resposta à pergunta "O que você considera como Resolução de Problemas, depois de ter estudado sobre?":

E6: Que a gente tem que dar várias possibilidades para a criança, de formas de raciocínio. Existem várias formas diferentes de você resolver um problema, e que cada criança é diferente, cada criança vai seguir uma linha de raciocínio diferente e a gente tem que respeitar isso.

Pesquisadora: No questionário, você respondeu que compreende a Resolução de Problemas como uma "Apresentação de problemas, que muitas vezes cotidianos, que são resolvidos a partir de contas matemáticas para prática e/ou aplicação da matemática para melhor fixação". Você ainda concorda essa concepção?

E6: Concordo, mas eu colocaria que a gente vai trazer coisas cotidianas, mas que vamos trazer coisas concretas também, principalmente com as crianças menores, pra elas conseguirem fazer a resolução.

(Trechos da entrevista feita com o estudante participante da pesquisa, 2018).

Outro ponto que complementa a questão dessa formação de concepções é acerca da compreensão sobre o que é a Matemática, no qual a maioria dos estudantes respondeu prontamente "contas", "números" e "raciocínio". Esse tipo de definição pode representar certa influência na formação da concepção sobre a 
Resolução de Problemas, no que os estudantes salientam como as formas e possibilidades de encontrar a resposta mais rápido, ou que são apenas cálculos e exercícios.

As respostas divergiram dessa perspectiva mais tradicional de ensino, contudo, quando os estudantes demonstraram a preocupação na criança como centro do processo de ensino-aprendizagem, sendo a ação docente um meio de auxílio da interpretação e da construção do conhecimento relacionado com o cotidiano, segundo observado nas transcrições a seguir:

E2: Eu considero que posso transformar algo ruim, em algo legal pra ajudar as crianças. [No seu questionário, você respondeu que seria "Encontrar alternativas para melhor[ar] o desenvolvimento matemático"] Isso, é transformar uma coisa branca, em uma coisa divertida para que a criança se envolva, para que ela aprender, não o bruto que ela aprende o $2+2$. É uma forma diferente para que a criança possa aprender.

E4: Considero como desenvolvimento do raciocínio lógico, o desenvolvimento de tudo, na verdade, até da percepção do que eu preciso extrair da questão, do que vou utilizar; e na vida tem isso. [...] É muito mais do que só olhar uma questão com dificuldade e tentar solucionar. É olhar uma questão e ver o que eu posso fazer, vendo como uma brincadeira, um desenho.

E6: [...] A gente tem que dar várias possibilidades para a criança, de formas de raciocínio, existem várias formas diferentes de você resolver um problema, e que cada criança é diferente, cada criança vai seguir uma linha de raciocínio diferente e a gente tem que respeitar isso.

E8: [...] Uma coisa que eu entendi é que através da Resolução de Problemas é que a criança ela lê, ela observa, ela pensa e através disso, ela sempre tenta achar uma solução.

(Trechos da entrevista feita com os estudantes participantes da pesquisa, 2018).

Podemos considerar que as concepções apresentadas pelos estudantes e futuros educadores que ensinaram Matemática sobre Resolução de Problemas, oriundos do Curso de Formação de Docentes, demonstram uma transição entre o pensamento tradicional e as novas ideias metodológicas, uma vez que a compreensão do desenvolvimento da criança e de como ocorre os processos de aprendizagem também estão evoluindo.

\section{CONSIDERAÇÕES FINAIS}

Com esta pesquisa, salientamos que há inúmeros fatores que influenciam a formação das concepções nos processos de ensino e aprendizagem.

Um desses fatores diz respeito à influência da formação da docente que ministrava a disciplina em questão, que demonstrava oscilação de concepções sobre a Resolução de Problemas por meio da apresentação do conteúdo, expressa na exposição oral e na reprodução de textos, e na realização de atividades ao final de cada tópico abordado. Assim, emerge a hipótese da influência que a disciplina e o modo como este conteúdo foi conduzido reage entre o conhecimento informal (senso comum) e o conhecimento específico. A preocupação com esta formação está na reprodução das dificuldades, acreditando que se o professor já não gosta da disciplina por falta de afinidade e desenvoltura, poderá transmitir esses sentimentos por meio da ausência de empenho em sala de aula.

Entretanto, como evidenciado durante todo o artigo, os futuros professores situados na fase de transição de concepções já apresentam novos olhares para a educação, buscando estratégias que consolidem significativamente as aprendizagens.

\section{AGRADECIMENTOS}

Agradecimentos à Universidade Federal do Paraná (UFPR), ao Programa de Pós-Graduação em Educação em Ciências e em Matemática (PPGECM), e à orientação da Professora Tania Teresinha Bruns Zimer. 


\section{REFERÊNCIAS}

[1] Allevato, Norma Suely Gomes; Onuchic, Lourdes de la Rosa. Ensino-Aprendizagem-Avaliação de Matemática: por que Através da Resolução de Problemas?. In: ONUCHIC, Lourdes de la Rosa; Allevato, Norma Suely Gomes; Noguti, Fabiane Cristina Höpner; Justulin, Andressa Maria (Orgs.). Resolução de Problemas: Teoria e Prática. Jundiaí, Paco Editorial; 2014, 35-52p.

[2] Bermudes, Wanderson Lyrio; et al. Tipos de escalas utilizadas em pesquisas e suas aplicações. In: Vértices. Campos dos Goytacazes - RJ, v. 18, n.2, p. 7-20, maio/agosto, 2016.

[3] Bogdan, Roberto C.; Biklen, San Knopp. Investigação Qualitativa em Educação: Uma introdução à teoria e aos métodos. Tradução Maria João Alvarez, Sara Bahia dos Santos e Telmo Mourinho Baptista. Porto: Porto Editora, 1994, $335 \mathrm{p}$.

[4] Mitsuuchi, Jéssica Tomiko Araújo. Concepções acerca da Resolução de Problemas Matemáticos: A formação inicial do Educador em evidência. Trabalho de Conclusão de Curso. Universidade Federal do Paraná, 2018, 112p. Disponível em <http://www.pedagogia.ufpr.br/tcc2018.html>.

[5] Polya, George. A arte de Resolver Problemas. Trad. Heitor Lisboa de Araújo. Rio de Janeiro: Editora Interciência, 2006, 203p.

[6] Smole, Katia Stocco; Diniz, Maria Ignez (Orgs.). Ler, escrever e resolver problemas: Habilidades básicas para aprender Matemática. Porto Alegre: Artmed Editora, 2001; 203 p. 


\section{Capítulo 25}

\section{Atividade investigativa: Resolvendo um problema envolvendo sistema de equações do $1^{\circ}$ Grau}

\section{Flaviano Gomes Nascimento}

Taiane Santana de Carvalho

Grace Dórea Santos Baqueiro

Resumo: Relata-se o resultado de uma experiência vivenciada por dois professores em formação continuada. Com base nas três fases da investigação matemática descritas por Ponte, Brocardo e Oliveira (2016), aplicou-se a estudantes do 8. ${ }^{\circ}$ ano de uma escola pública do interior da Bahia uma aula investigativa envolvendo sistema de equações do 1. o grau. A experiência foi satisfatória, pois propiciou mobilização de saberes pelos discentes, que, ao buscarem solução, tiveram que criar estratégias, raciocinar logicamente e verificar a validade da estratégia adotada.

Palavras-chave: Ensino de Matemática; Investigação Matemática; Sistema de Equações do $1^{\underline{o}}$ grau; Ensino Fundamental. 


\section{INTRODUÇÃO}

Participando de um curso de pós-graduação em educação matemática de uma instituição estadual da Bahia, fomos percebendo a importância de delinearmos um trabalho pedagógico voltado ao resgate e valorização do saber matemático. Descobrimos também que é preciso investir em atividades que possam alcançar o aluno, desenvolvendo seu senso crítico e fazendo-os pensar - enfim, despertando-o para o conhecimento matemático, que segundo Steinbring (2005) não é previamente fornecido, mas sim construído por meio de atividades sociais e interpretações individuais.

Em um dos componentes do curso, intitulado 'Resolução de problemas e investigação matemática', estudamos um capítulo do livro Investigações matemáticas na sala de aula, em que Ponte, Brocardo e Oliveira (2016, p. 25) frisam "que as investigações matemáticas são um tipo de atividade que todos os alunos devem experimentar, pois se coloca a questão de saber como será possível realizá-las na sala de aula de Matemática". Salientam que "investigar significa trabalhar com questões que nos interpelam e que se apresentam no início de modo confuso, mas que procuramos clarificar e estudar de modo organizado" (p. 9).

Para esses autores, a aula investigativa tem início com uma situação-problema para cuja resolução os alunos, individualmente ou em grupo, buscam estratégias. Apontam, ademais, que uma atividade investigativa deve ser organizada de modo a contemplar três fases que a tornam mais significativa e completa:

(i) introdução da tarefa, em que o professor faz a proposta à turma, oralmente ou por escrito, (ii) realização da investigação, individualmente, aos pares, em pequenos grupos ou com toda a turma, e (iii) discussão dos resultados, em que os alunos relatam aos colegas o trabalho realizado. (Ponte; Brocardo; Oliveira, 2016, p. 25).

Este relato de experiência é fruto de uma atividade desenvolvida no componente supracitado, no qual, após estudo de texto de Ponte, Brocardo e Oliveira (2016), escolhemos um problema matemático e o aplicamos a nossos alunos, promovendo um ambiente de investigação matemática na sala de aula, com o intuito de verificar se a utilização desse tipo de investigação como método pode constituir um caminho para a construção de conhecimento matemático.

\section{RELATANDO A EXPERIÊNCIA}

No segundo semestre de 2018, a atividade foi aplicada pelos dois primeiros autores do presente relato (então cursando pós-graduação em educação matemática) a 15 alunos do 8o ano da Escola Municipal Jairo Azi, em Ouriçangas, BA, no turno oposto ao das aulas dos discentes, totalizando três horas-aula. A escolha do turno e do local da aplicação (a Biblioteca Municipal Professora Anna Maria Ramos de Cerqueira) decorreu do fato de, naquele momento, a rede municipal de ensino haver recém-encerrado uma greve de professores - daí a necessidade de evitar colisões com horários de aula dos alunos, o que poderia comprometer o plano anual de ensino.

Organizamos a atividade em três fases, seguindo orientações de Ponte, Brocardo e Oliveira (2016):

(i) Introdução da tarefa: Conversamos sucintamente com a turma sobre a proposta da aula investigativa, relatando os motivos que conduziram à escolha do problema envolvendo sistema de equações do $1 .^{\circ}$ grau. Explicamos, com vários exemplos, o que seria uma investigação e expusemos o objetivo da atividade. Todos ficaram atentos às instruções iniciais, colaborando com essa apresentação da proposta. Ficaram bastante curiosos quando informados de que todo o processo precisaria ser registrado com gravações e algumas fotos. Sobre este primeiro momento, ao qual se referem como arranque da aula, Ponte, Brocardo e Oliveira (2016, p. 26) esclarecem:

Essa fase, embora curta, é absolutamente crítica, dela dependendo todo o resto. 0 professor tem de garantir que todos os alunos entendem o sentido da tarefa proposta e aquilo que deles se espera no decurso da atividade. 0 cuidado posto nesses momentos iniciais tem especial relevância quando os alunos têm pouca ou nenhuma experiência com as investigações. ((Ponte; Brocardo; Oliveira, 2016, p. 26). 
Os alunos se agruparam em cinco trios, designados Grupo 1 a Grupo 5, em cada um dos quais um aluno foi incumbido de gravar os diálogos em aparelho celular. Em seguida, distribuímos aos grupos uma folha impressa com o problema. Onuchic (1999) define problema como tudo aquilo que não se sabe fazer, mas que se está interessado em resolver. Explica também que o problema não deve ser tratado como caso isolado, mas como passo para alcançar a natureza interna da Matemática e conhecer seus usos e aplicações.

Utilizamos um problema extraído da prova da primeira fase da Olimpíada Brasileira de Matemática das Escolas Públicas (OBMEP), nível 2, de 2018 (Figura 1). A questão foi selecionada por envolver um conteúdo conhecido pelos alunos e por estar em consonância com a definição de problema de Onuchic (1999).

Figura 1-0 problema aplicado.

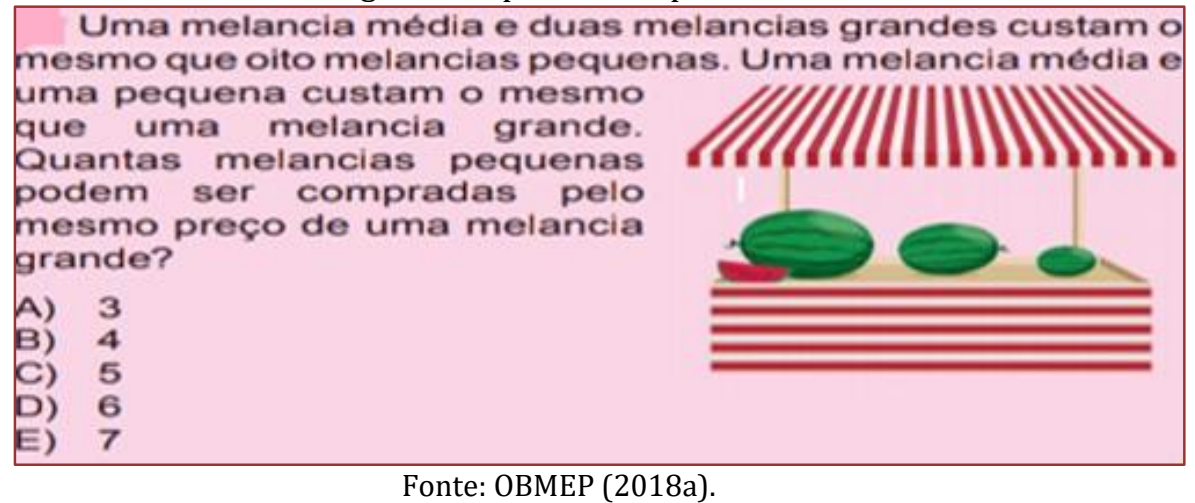

Consideramos que o problema era simples para alunos do 8.ำ ano, mas concordamos com Ponte, Brocardo e Oliveira (2016, p. 9) que, "em contextos de ensino e aprendizagem, investigar não significa necessariamente lidar com problemas muito sofisticados na fronteira do conhecimento". Um problema deve possibilitar ao aluno desenvolver estratégias e buscar diferentes caminhos para solucioná-lo de acordo com sua realidade e raciocínio.

Nesse sentido, a investigação matemática aproxima-se da resolução de problema, pois, de acordo com Ponte, Brocardo e Oliveira (2016, p. 9), "investigar significa, tão só, que formulamos questões que nos interessam, para as quais não temos resposta pronta, e procuramos essa resposta de modo tanto quanto possível fundamentado e rigoroso". De fato, o problema proposto não tinha resposta pronta; pelo contrário, a intenção, ao escolhê-lo, foi de incitar nos alunos a busca de vários caminhos, que poderiam determinar diferentes respostas, todas coerentes conforme o contexto em que os estudantes situassem o problema.

Uma vez assegurados de que os alunos haviam compreendido a atividade, passamos à segunda fase da intervenção:

(ii) Realização da investigação: Solicitamos que os alunos iniciassem a atividade com uma leitura individual do problema e fomos monitorando a turma, buscando com isso extrair informações sobre alguns aspectos, com base nas reações coletivas e individuais suscitadas pela leitura.

Percebemos que após lerem o problema os grupos dialogaram bastante para chegar ao resultado final. Tais diálogos gravados foram transcritos minuciosamente. As falas deixaram claro que os Grupos 1, 3, 4 e 5 exploraram o problema, formularam questões e levantaram conjecturas, como mostram trechos do diálogo do Grupo 1 (Quadro 1). 
Quadro 1 - Diálogo do Grupo 1.

Aluna A: Vamos chamar cada melancia de uma letra?

Aluna B: Isso mesmo. Aí a gente faz a questão por sistema.

Aluna C: Mas eu não sei fazer um sistema com três letras. Só aprendi com duas letras.

Aluna B: Vamos montar e ver o que é que dá.

Aluna A: Pelo que diz a questão, vamos chamar a melancia grande de $G$, a melancia média de $\mathrm{M}$ e a melancia pequena de P.

Aluna B: Então podemos dizer que $\mathrm{M}$ mais dois $\mathrm{G}$ é igual a oito $\mathrm{P}$ e que $\mathrm{M}$ mais $\mathrm{P}$ é igual a $\mathrm{G}$.

Aluna A: Olha só, meninas: podemos dizer que $M$ é igual a $G$ menos $P$.

Aluna C: Verdade. Agora ficou fácil. Vamos substituir o valor de M na outra equação.

Aluna A: Então fica que G menos P mais dois G é igual a oito P.

Aluna C: A resposta é 3.

Aluna A: Sim, porque quando a gente fizer a divisão, fica que G é igual a três $\mathrm{P}$.

Fonte: Dados da pesquisa.

À medida que éramos solicitados, fazíamos as intervenções de esclarecimento necessárias, sem porém, dar todas as pistas, mas apenas provocando-os para que continuassem buscando a resposta.

Ao se propor uma tarefa de investigação, espera-se que os alunos possam, de uma maneira mais ou menos consistente, utilizar os vários processos que caracterizam a atividade investigativa em Matemática. [...] alguns destes processos são: a exploração e formulação de questões, a formulação de conjecturas, o teste e a reformulação de conjecturas e, ainda, a justificação de conjecturas e avaliação do trabalho. (Ponte; Brocardo; Oliveira, 2016, p. 29).

Assim, desempenhamos um papel mais propriamente de "retaguarda", permitindo-nos observar como se desenvolvia o trabalho dos grupos. Os Grupos 1, 2 e 5 demonstraram total autonomia na resolução, pois em momento nenhum solicitaram nossa presença para elucidar dúvidas. Já os grupos 3 e 4 o fizeram em diversos momentos, indagando, por exemplo, se estavam no caminho que conduziria à resposta correta.

Sem antecipar-lhes a solução, explicávamos que não havia uma resposta correta única e que no final da atividade iríamos socializar as respostas, quando então teriam a oportunidade de verificar se acertaram. 0 Quadro 2 reproduz trechos do diálogo do Grupo 3.

Quadro 2- Diálogo do Grupo 3.

Aluna D: Professor, eu fiz essa questão na prova da Olimpíada de Matemática.

Aluna E: Claro que a gente fez. Olha aí escrito na atividade: “OBMEP 2018”.

Aluna D: Ah! É mesmo.

Aluno F: Professor, não tô entendendo.

Professor: Veja os elementos que a questão está lhe oferecendo e veja também qual é a pergunta que está sendo feita.

Aluna D: Eu sei como é que faz.

Aluno E: Então faz aí.

Aluna D: Chamamos $\mathrm{M}$ de média, $\mathrm{G}$ de grande e $\mathrm{P}$ de pequena.

Aluna E: Eu vou fazer só as contas, porque eu não sei mais nada.

Aluna D: M mais dois G é igual a oito P e M mais P é igual a G.

Aluno F: Agora eu estou conseguindo entender! Escreve aí que M é igual a G menos P.

Aluna D: Isso mesmo! Agora a gente pode ir na primeira equação e no lugar de $\mathrm{M}$ a gente coloca $\mathrm{G}$ menos $\mathrm{P}$.

Aluna E: Hum! Então fica que G é igual a nove P. Dividindo, temos que G é igual a três $P$.

Fonte: Dados da pesquisa.

Esse momento da interferência do professor foi importante para incentivar os alunos na busca do resultado final. Ao longo da atividade, os alunos foram tornando-se mais autônomos e confiantes em sua capacidade de resolver o problema. Ressalte-se que o Grupo 2, além de explorar o problema, formular questões e levantar conjecturas, por influência do aluno G, fez também o teste de conjecturas, validando a solução encontrada (Quadro 3). 
Quadro 3- Diálogo do Grupo 2.

Aluno G: Essa questão dá para fazer como aquela dos carros e das motos no estacionamento.

Aluno H: Então a gente pode dar letra para cada melancia?

Aluno G: Sim, podemos.

Aluno I: Chamando G de melancia grande, $\mathrm{M}$ de melancia média e $\mathrm{P}$ de melancia pequena.

Aluno H: Como é que vamos fazer isso se o professor ano passado ensinou com X e Y?

Aluno I: Escreve aí: $M$ mais dois $G$ é igual a oito $P$ e M mais P é igual a G.

Aluno H: Hum! M também pode ser escrito como G menos $P$.

Aluno G: Isso mesmo. Agora a gente troca o valor de M na outra equação.

Aluno H: Anota aí: a primeira equação vai ficar com G menos P mais dois G, que é igual a oito P.

Aluno G: Somando G com dois $G$ teremos três $G$ no primeiro membro e passa para o segundo membro

menos $\mathrm{P}$ como positivo, que ficará nove $\mathrm{P}$.

Aluno $\mathrm{H}$ : Assim, ficará três G igual a nove P.

Aluno H: Dividindo, fica que G é igual a três $P$.

Aluno G: A resposta é a letra a. Vamos voltar na questão para ver quantas melancias pequenas é igual a

uma média?Se $M$ é igual a $G$ menos $P$, vamos ter que $M$ é igual a dois $P$.

Aluno I: É mesmo! Ficou do mesmo jeito que diz a questão.

Aluno G: Sim, uma melancia média e duas grandes custam o mesmo que oito melancias pequenas.

Aluno H: Porque se uma média é duas pequenas e uma grande é três pequenas, então, $3+3+2=8$.

Fonte: Dados da pesquisa.

A justificação, ou prova das conjecturas, é uma vertente do trabalho investigativo que tende, com alguma frequência, a ser relegada a segundo plano ou até mesmo a ser esquecida, em especial nos níveis de escolaridade mais elementares. Ponte, Brocardo e Oliveira (2016, p. 37) apontam ser "fundamental, para que o processo investigativo não saia empobrecido, que o professor procure levar aos alunos o caráter provisório das conjecturas".

Consideramos que a segunda fase da investigação foi satisfatória, pois os alunos demonstraram exercer raciocínio e dispor de conhecimentos matemáticos ao resolverem a situação-problema. Como professores em formação continuada, percebemos a importância de estarmos atentos ao pensamento de nossos alunos. Devemos de alguma forma, oralmente ou por escrito, solicitar-lhes que expressem o que estão pensando. Só assim poderemos avaliar mais concretamente o aprendizado de cada um. Nos diálogos, por exemplo, percebemos quais eram os alunos que conseguiram elaborar estratégias para resolver o problema e quais claramente tinham dúvidas. Nesse sentido, agrupá-los em trios foi uma boa decisão, por permitir que seus integrantes pudessem aprender com os colegas.

Recolhemos as folhas impressas contendo as anotações dos alunos e as devolvemos no encontro seguinte, em que trabalhamos a terceira fase da investigação.

(iii) Discussão dos resultados: Solicitamos que um membro de cada grupo viesse à frente do quadro para relatar como a atividade havia sido realizada.

No final de uma investigação, o balanço do trabalho realizado constitui um momento importante de partilha de conhecimentos. Os alunos podem pôr em confronto as suas estratégias, conjecturas e justificações, cabendo ao professor desempenhar o papel de moderador. (Ponte; Brocardo; Oliveira, 2016, p. 41).

Comparando as soluções, pudemos perceber semelhanças nos caminhos percorridos pelos Grupos 1 a 4 . A Figura 2 mostra como o Grupo 4 solucionou o problema. 
Figura 2 - Solução da atividade pelo Grupo 4.

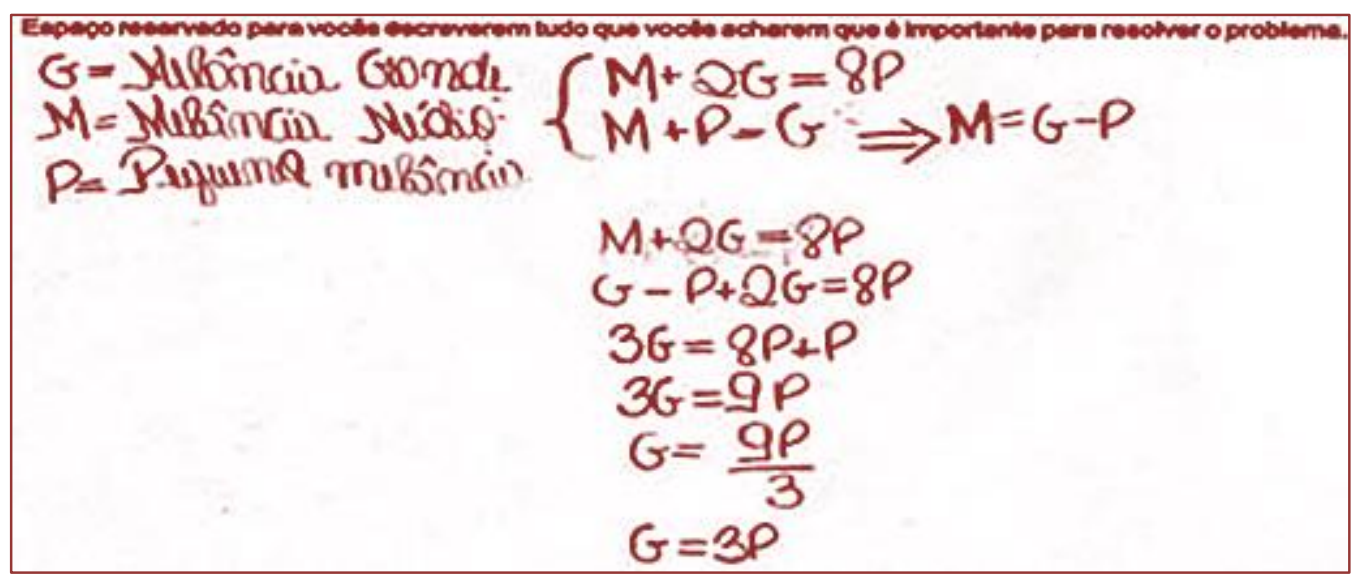

Tal solução está muito próxima da apresentada pela OBMEP (Quadro 4).

Quadro 4 - Solução apresentada pela OBMEP.

\section{QUESTÃo 3}

ALTERNATIVA A

Pelo enunciado, temos duas igualdades: $M+2 G=8 P$ e $M+P=G$, em que $P, M$ e $G$ representam os preços das melancias pequena, média e grande, respectivamente.

Da primeira relaçăo temos que $M=8 P-2 G$. Substituindo na segunda relação, temos: $G=8 P-2 G+P ; l o g o$, $G=3 P$. Assim, pelo preço de uma melancia grande podemos comprar 3 pequenas.

$$
\text { Fonte: OBMEP (2018b). }
$$

No entanto, observamos que nas respostas dos Grupos 1 a 4 os alunos expressaram as letras P, M e G como sendo melancias pequenas, médias e grandes, respectivamente, não deixando claro se associavam tais adjetivos ao preço das frutas. Tal fato só nos chamou atenção quando estávamos redigindo este relato, sem que a dúvida pudesse ser esclarecida durante a socialização. 0 Grupo 5, por sua vez,empregou estratégia diferente (Quadro 5 e Figura 3).

Quadro 5 - Diálogo do Grupo 5.

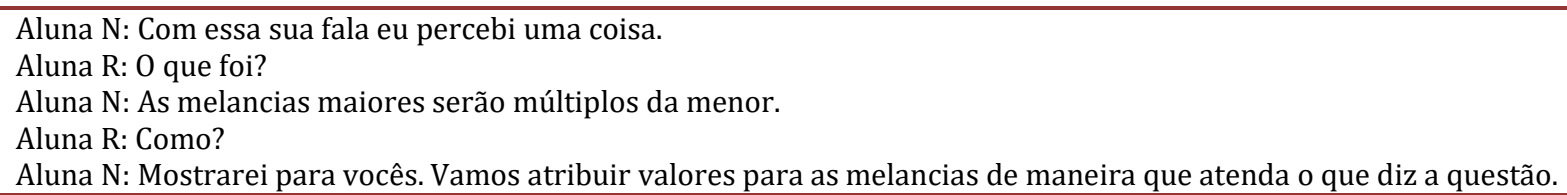
Fonte: Dados da pesquisa.

A solução do Grupo 5 se vale de um pensamento numérico que, como explica a Base Nacional Comum Curricular (BNCC), "implica o conhecimento de maneiras de quantificar atributos de objetos e de julgar e interpretar argumentos baseados em quantidades” (Brasil, 2018, p. 268).

Foi interessante, no momento da socialização, termos duas soluções diferentes, o que tornou a discussão mais rica, pois os alunos puderam confrontar suas estratégias, conjecturas e justificações. 
Figura 3 - Solução do problema elaborada pela aluna N do Grupo 5.

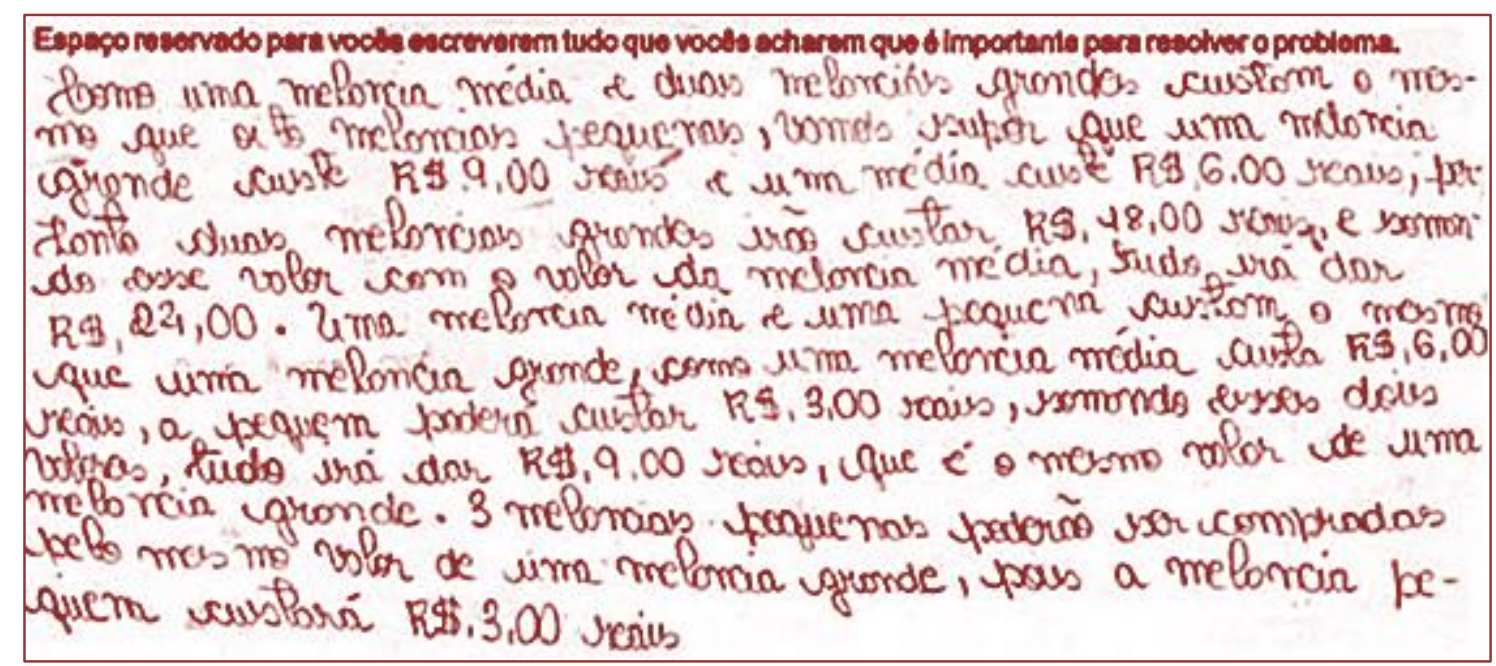

\section{CONSIDERAÇÕES FINAIS}

Este relato visou descrever a aplicação de uma atividade investigativa, de modo a evidenciar as três fases que, segundo Ponte, Brocardo e Oliveira (2016), a compõem.

Constatamos que numa aula de investigação matemática a condução e o direcionamento das atividades dependem do professor, pois este precisa conhecer seus discentes, para que assim se estabeleça um bom ambiente de aprendizagem e para que as investigações transcorram com sucesso. Cabe ressaltar que tais atividades demandam tempo, tanto para sua elaboração quanto sua aplicação, o que, porém, não deve ser visto como empecilho para que os professores adotem esse tipo de metodologia.

Foi muito importante analisar os diálogos dos grupos, pois percebemos que os alunos que sabiam resolver o problema ajudaram os que não dispunham de estratégias definidas. Solicitar as soluções escritas também nos foi bastante útil. A análise das duas soluções nos levou às seguintes indagações: Será que os alunos dos Grupos 1 a 4 utilizaram as letras P, M e G sabendo seus reais significados? Os alunos do Grupo 5 deixaram de usar o sistema de equações do 1.ำ grau por terem dificuldades com esse conteúdo? As respostas a tais questões poderiam ter sido reveladas no momento da socialização, mas tais questionamentos só nos ocorreram enquanto escrevíamos este relato.

Concluímos que as atividades investigativas são ricas, instigantes e doravante farão parte de nossa prática em sala de aula, por possibilitarem a partilha de conhecimentos entre docente e discente, além de constituírem um caminho para a construção do conhecimento matemático.

\section{REFERÊNCIAS}

[1] Brasil, Ministério da Educação. Base nacional comum curricular. Brasília: MEC, 2018.

[2] OBMEP - Olimpíada Brasileira de Matemática das Escolas Públicas. 8. e 9..$^{\circ}$ anos do ensino fundamental,nível 2, 1.a fase. 2018a. Disponível em: <http://www.obmep.org.br/provas_static/pf1n2-2018.pdf>. Acesso em: 12 jun. 2019.

[3] OBMEP - Olimpíada Brasileira de Matemática das Escolas Públicas. 8.0 e 9. anos do ensino fundamental,nível 2, 1. ${ }^{a}$ fase: solução da prova da $1 .^{a}$ fase. 2018b. Disponível em: <http://www.obmep.org.br/provas_static/sf1n22018.pdf>. Acesso em: 12 jun. 2019.

[4] Onuchic, L. DE LA R. Ensino-aprendizagem de matemática através da resolução de problemas. In: Bicudo, M.A.V. (Org.).Pesquisa em educação matemática: concepções e perspectivas. São Paulo: UNESP, 1999. p. 199-218.

[5] Ponte, J.P. DA; Brocardo, J.; Oliveira, H. Investigação matemática na sala de aula. Belo Horizonte: Autêntica, 2016.

[6] Steinbring, H. The construction of new mathematical knowledge in classroom interaction: an epistemological perspective. Dordrecht: Springer, 2005. 


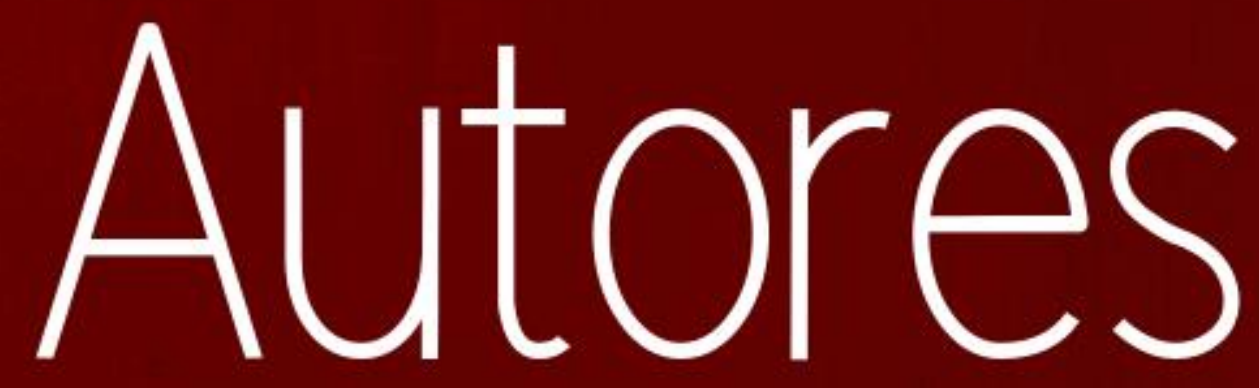




\section{ADRIANA DE SOUZA LIRA}

Cursando Graduação Licenciatura em MATEMÁTICA no(a) UNIVERSIDADE FEDERAL DO TOCANTINS. 2019 Evento: Encontro Nacional de Educação Matematica. Natureza: ENCONTRO. Município: Cuiabá; UF: MT. Participou como: Palestrante; Título: A TRILHA DOS NÚMEROS: EXPLORANDO PISTAS E ENCONTRANDO MÚLTIPLOS. 2019 Evento: Semana Academica da Matematica. Natureza: ENCONTRO. Município: Araguaína; UF: TO. Participou como: Palestrante; Título: Matemágica na prática. 2018 Evento: Semana Academica da Matematica. Natureza: EXPOSIÇÃO. Município: Araguaína; UF: TO. Participou como: Palestrante; Título: TRILHA DOS MÚLTIPLOS.

\section{ADRIANO ARAQUEM BAIA MENEZES}

Graduando em Licenciatura Integrada em Matemática e Física pela Universidade Federal do Oeste do Pará - UFOPA. Atualmente, é professor de pré-vestibulares e concursos, atuando também como professor orientador do Programa de Iniciação Cientifica - PIC da OBMEP. Pesquisador das áreas de didáticas de ensino sobre tudo com a utilização de jogos com cartas e mágicas com cartas, além de desenvolver pesquisas na área de Modelagem Matemática aplicada ao ensino.

\section{ALINE ALVES DE OLIVEIRA}

-Mestrado em Economia pela Universidade Federal do Rio Grande do Norte

-Doutoranda em economia pela Universidade Federal Fluminense

-Professora de Economia na Universidade Regional do Cariri - URCA

-Pesquisadora dos grupos de estudo: Observatório das Migrações no estado do Ceará e

Territorialidades econômicas e desenvolvimento regional e urbano.

\section{ANA JOSICLEIDE MAIA}

-Graduação em Agronomia pela ESAM (Escola Superior de Agricultura de Mossoró)

-Mestrado e doutorado em agronomia na área de concentração em fitotecnia pela UFC

(universidade federal do Ceará)

-Professor adjunto da Universidade Regional do Cariri (URCA)

\section{ANA PAULA BERGO DA SILVA}

Possui graduação em Pedagogia pela Universidade Estadual de Maringá (2017) é pós graduanda em Metodologia da Matemática pela Faculdade São Luís (2020). No período de 2014 à 2016 participou do PIBID subprojeto Pedagogia, Foco Matemática. É membro da Oficina Pedagógica de Matemática (OPM/UEM). Desenvolve pesquisas nos seguintes temas: ensino e aprendizagem e o desenho como linguagem matemática.

\section{ANA ROBERTA DUARTE PIANCÓ}

Graduação em geografia na Universidade Regional do Cariri- URCA, especialista em geografia área de concentração : Análise Ambiental Urbana na UECE. Mestrado em Geografia, área de concentração : regionalização e análise regional na Universidade Federal de Pernambuco- UFPE. Pró-reitora da Pró-reitoria de Planejamento e Avaliação da URCA. Líder do Grupo de Pesquisa CNPq : Território,Espaço e Movimentos Sociais. Coordenadora do Laboratório de Geografia Agrária Labgea

\section{ARIS TIMAR ROBERTA DE OLIVEIRA}

Possui graduação em Pedagogia e História e atualmente é lotada na Escola Municipal Herculano Borges. 


\section{CAMILA LIMA DA COSTA}

Licenciada em Matemática pela Universidade Estadual de Alagoas (2013), Especialista em Educação Matemática pela Faculdade São Luís de França (2014), Mestra em Matemática pela Universidade Federal de Alagoas (2016). Professora substituta no Instituto Federal de Educação, Ciência e Tecnologia de Alagoas - IFAL/Campus Maceió (2018 - 2019). Atualmente é professora efetiva na Secretaria de Estado da Educação de Alagoas e pós-graduanda em Educação Especial e Inclusiva pelo Centro Universitário Internacional. Tem experiência nas áreas de Matemática, Educação Matemática e Educação Especial e Inclusiva.

\section{CARMEN LUCIA GIUNTINI}

Possui graduação em Ciências Biológica pela Universidade do Sagrado Coração de Jesus-Bauru-SP, com Complementação em Matemática pela Universidade de Cuiabá-MT, especialização em PROEJA pelo Instituto Federal de Mato Grosso. Atualmente professora efetiva do Município de Várzea Grande-SMECEL e aposentado pela Secretaria Municipal de Educação de Mato Grosso-SEDUC-MT.

\section{CIBELLE TEIXEIRA DE OLIVEIRA}

-Graduanda em Pedagogia VII semestre, pela Universidade Regional do Cariri- URCA -Secretária Executiva da Pró-reitoria de Planejamento e Avaliação da URCA.

\section{CLÁUDIA LANDIN NEGREIROS}

Doutora em Educação pela Universidade Federal do Rio Grande do Sul - UFRGS (2013). Atualmente é professora Adjunta III da Universidade do Estado de mato Grosso (UNEMAT). Coordenadora do Curso de Licenciatura em Letras Português - Inglês - UAB - DEAD - UNEMAT. Docente do Mestrado profissional em Letras - Profletras - UNEMAT - Campus de Sinop. Docente do Programa de PósGraduação Stricto Sensu em Ensino de Ciências e Matemática - PPGECM - UNEMAT. Docente do Curso de Licenciatura em Matemática - MT.

\section{DAYSE DO PRADO BARROS}

Licenciada em Matemática, especialista em Educação Especial e especialista em Educação de Surdos. Mestre em Educação na linha Educação em Ciências e Matemática pela Universidade de Brasília (UnB). Integra os seguintes grupos de pesquisa: Grupo de Estudos e Pesquisas sobre Aprendizagem Lúdica: Pesquisas e Intervenções em Educação e Desporto (GEPAL) e Grupo de Investigação no Ensino da Matemática (GIEM), ambos na Universidade de Brasília - UnB. Professora do Atendimento Educacional Especializado (AEE) da Secretaria de Estado de Educação do Distrito Federal.

\section{DÉCIO DE OLIVEIRA GROHS}

Mestrando em Ensino de Ciências e Matemática, UFAC, Especialista em Matemática e Biologia, FAVENI, 2018, Licenciado em Matemática, UEA, 2010. Professor da rede pública do Estado do Amazonas. Pesquisador do Grupo de Estudo e Pesquisa em Linguagens, Práticas Culturais em Ensino de Ciências e Matemática (GEPLIMAC/UFAC).

\section{DOUGLAS LOPES DO NASCIMENTO}

Licenciado em Matemática pelo IFAL - Instituto Federal de Alagoas (2018). Especialista em Ensino de Matemática pela FAVENI - Faculdade Venda Nova do Imigrante (2019). Atualmente é Docente da Rede Estadual de Ensino de Alagoas na Escola Estadual Professora Aurelina Palmeira de Melo, atuando nos ensino fundamental e médio. 


\section{EDILSON DOS SANTOS ARAÚJO}

Possui graduação em Pedagogia (2017) pela Universidade Estadual de Maringá (UEM). Mestre em Educação (2020) pela Universidade Estadual de Maringá, no Programa de Pós-Graduação em Educação (PPE/UEM) na linha de pesquisa Ensino, Aprendizagem e Formação de Professores. Fez parte do PIBID subprojeto Pedagogia, Foco Matemática (2014-2018). É membro do Grupo de Pesquisa e Ensino Trabalho Educativo e Escolarização (GENTEE/CNPq) e da Oficina Pedagógica de Matemática (OPM/UEM). Desenvolve pesquisas nos seguintes temas: ensino e aprendizagem; organização do ensino de matemática; formação de professores; e operações mentais.

\section{EDMILSON PEREIRA}

Possui graduação em Física e Matemática pelo Instituto Federal de Educação, Ciência e Tecnologia do Pará (IFPA). Graduação em Licenciatura Integrada Em Educação em Ciências, matemática e Linguagens pela Universidade Federal do Pará (UFPA).

\section{ELIANE MARIA VANI ORTEGA}

Doutora em Educação pela Faculdade de Educação da USP, São Paulo. Mestre em Educação pela Faculdade de Filosofia e Ciências da Unesp, Marília. Licenciada em Matemática pela Faculdade de Ciências e Tecnologia da Unesp, Presidente Prudente. Ampla experiência como professora de Matemática na Educação Básica, níveis fundamental e médio, público e particular. É professora do Departamento de Educação da FCT-Unesp, Presidente Prudente e atua nos cursos de Pedagogia e Matemática. Pesquisa a formação de professores que ensina Matemática nos anos iniciais, currículos de Matemática e acesso ao saber matemático.

\section{ELISANGELA PAVANELO}

Possui graduação em Matemática - Licenciatura pela Universidade Estadual Paulista Júlio de Mesquita Filho UNESP - SJRP (2000), mestrado em Educação Matemática pela Universidade Estadual Paulista Júlio de Mesquita Filho UNESP - Rio Claro (2004) e doutorado na linha de pesquisa em Ensino de Ciências e Matemática, na USP - SP. Até 2008 foi coordenadora de Curso de Matemática - Licenciatura, professora e Membro da Comissão de Ensino do Centro Universitário de Rio Preto UNIRP. Até 2015, foi docente da Universidade do Vale do Paraíba (UNIVAP) nos cursos de Engenharia, Licenciatura em Matemática e Pedagogia. Em 2016 realizou Pós-doutorado no Instituto Tecnológico de Aeronáutica (ITA), trabalhando com o conceito de Blended Larning e aprendizagem colaborativa no ensino de Cálculo Diferencial e Integral para cursos de Engenharia. Atualmente é docente do Departamento de Matemática da UNESP/FEG em Guaratinguetá, é pesquisadora no grupo de pesquisa GEPEM - Grupo de Estudos e Pesquisa em Educação Matemática. Tem experiência na área de Educação Matemática, com ênfase em disciplinas semipresenciais, Educação a Distância, TDIC (Tecnologias Digitais da Informação e Comunicação) e formação de professores de Matemática

\section{ELIZANE GOMES DO ESPIRITO SANTO TAQUES}

Possui graduação em Pedagogia e atualmente está como TDI na Escola Estadual José Ourives

\section{EUGENIA BRUNILDA OPAZO URIBE}

Formada em Pedagogia en Matemáticas y Física pela Universidad Austral de Chile (1985). Mestre em Matemática pela Universidade Estadual de Campinas (1989). Doutora em Engenharia Mecânica pela Universidade Estadual de Campinas (2002). Professora Associado IV do Campus de Três Lagoas da Universidade Federal de Mato Grosso do Sul. Editora responsável da Revista Ensin@ UFMS. Membro do Conselho Editorial da Revista Eletrônica de Educação Tutorial (REPET) - Três Lagoas/MS. Membro do GForP - Grupo de Estudos em Formação de Professores da UFMS/CPTL. Membro do Grupo LEA UFMS - Laboratório de Ensino e Pesquisa Multidisciplinar. Atua nas áreas de Matemática, Ensino de Matemática e Formação de Professores. 


\section{FERNANDA SOUZA DE ARRUDA}

Possui graduação em Pedagogia e atualmente é concursada no estado e esta lotado na Escola Municipal Herculano Borges.

\section{FLAVIANO GOMES NASCIMENTO}

Graduado em Licenciatura em Matemática pela Universidade do Estado da Bahia. Pós Graduando em Educação Matemática pela Universidade do Estado da Bahia - UNEB e em Tecnologias e Educação Aberta e Digital. Atualmente atuando como Coordenador Pedagógico e Professor na Escola Municipal Jairo Azi de Ouriçangas - BA.

\section{GABRIEL ARAÚJO FREITAS}

Licenciado em Matemática (2018) pela Universidade Estadual de Goiás (UEG - Campus Quirinópolis) e Especialista em Metodologia do Ensino da Matemática (2019) pela Faculdade de Educação São Luís (FESL). Atualmente é docente da Secretaria Municipal de Educação de São Simão-GO, ministrando as disciplinas de Matemática/Geometria. Membro do CluMat (Clube de Matemática) da Universidade Estadual de Goiás, espaço formativo para professores de Matemática onde são desenvolvidas pesquisas no âmbito da formação de professores de Matemática, Organização do Ensino e da aprendizagem de conceitos Matemáticos, sendo ambos na perspectiva da Teoria Histórico-Cultural e Teoria da Atividade. É sócio da Sociedade Brasileira de Educação Matemática (SBEM). Tem experiência na área de Educação, com ênfase em Educação Matemática, tem interesse principalmente nos seguintes temas: Formação de Professores e processos de ensino e aprendizagem de Matemática.

\section{GABRIEL GERALDINO CARDOSO}

Graduando em Matemática - Licenciatura pela Universidade Estadual Paulista Júlio de Mesquita Filho - UNESP - Guaratinguetá (Início em 2017). Foi bolsista do Programa Institucional de Bolsas de Iniciação à Docência - (PIBID) pela Capes.

\section{GERSON DOS SANTOS FARIAS}

Mestrando no Programa de Pós-Graduação em Educação Matemática - PPGEdumat/INMA. Graduado em Licenciatura em Matemática pela Universidade Federal de Mato Grosso do Sul. Foi Bolsista do Programa de Iniciação à Docência - PIBID UFMS/CPTL e Bolsista no Programa de Educação Tutorial - Grupo PET Conexões de Saberes Matemática UFMS/CPTL. Foi integrante do Grupo de Estudos e Pesquisas em Formação de Professores - GForP, atuando nas áreas de Pedagogia Universitária e Formação de Professores e membro do LEA UFMS - Laboratório Multidisciplinar de Ensino e Pesquisa. Atualmente participa do Grupo de Pesquisa - Formação e Educação Matemática FORMEM. Tem experiência em Matemática com ênfase em Educação Matemática e Formação de Professores de Matemática.

\section{GILBERTO FRANCISCO ALVES DE MELO}

Doutor em Educação Matemática, UNICAMP, 2003. Mestre em Educação Matemática - UNICAMP, 1998. Licenciado em Ciências-Matemática-UFAC, 1988; Docente com atuação no Colégio de Aplicação-UFAC; no Mestrado Profissional em Ensino de Ciências e Matemática- MPECIM/UFAC e no Doutorado da REAMEC (Rede Amazônica de Educação em Ciências e Matemática) e Representante Estadual da REAMEC no Acre. Temas de Interesse de pesquisa: Prática Pedagógica; Saberes Docentes; Formação de Professores(as) de Matemática; Desenvolvimento Curricular e Educação Financeira. 


\section{GRACE DÓREA SANTOS BAQUEIRO}

Possui Doutorado em Educação Matemática pela Pontifícia Universidade Católica de São Paulo, Mestrado em Matemática pela Universidade Federal da Bahia (2001), Especialização em Matemática pela UFBA (2000) e graduação em Licenciatura em Ciências com Habilitação em Matemática pela Universidade Estadual de Feira de Santana (1987). Atualmente é professora assistente da Universidade do Estado da Bahia-UNEB, Campus II/Alagoinhas. Coordenadora regional das Olimpíadas Brasileira de Matemática das Escolas Publicas -OBMEP, promovido pelo Instituto Nacional de Matemática Pura e Aplicada -IMPA. Tem experiência na área de Matemática, com ênfase em Geometria Diferencial e na área de Educação Matemática com ênfase no pensamento algébrico.

\section{ITAMAR MIRANDA DA SILVA}

Doutor em Educação Matemática pelo Programa de Pós-Graduação em Educação em Ciências e Matemáticas do Instituto de Educação Matemática e Científica da Universidade Federal do Pará. Possui graduação em Matemática, pela Universidade Federal do Acre (2001) , Especialização em Ensino de Matemática, pela Universidade Federal do Acre e Bacharelado em Direito também, pela Universidade Federal do Acre( 2010). Atualmente é Professor Adjunto II, do Centro de Educação, Letras e Artes atuando na Licenciatura em Matemática e em Pedagogia, bem como no Mestrado Profissional em Ensino de Matemática e no Mestrado Profissional em Ensino de Ciências e Matemática da Universidade Federal do Acre.

\section{JANUÁRIA ARAÚJO BERTANI}

Possui graduação em Licenciatura Plena Em Matemática pela Faculdade de Filosofia Ciências e Letras Imaculada Conceição (1994), mestrado em Educação pela Universidade Federal de Santa Catarina (2002) e doutorado pelo Programa de Pós Graduação Ensino Filosofia e História das Ciências (universidade Federal da Bahia). Atualmente é professora adjunta da Universidade Estadual do Sudoeste da Bahia. Tem experiência na área de Educação Matemática, com ênfase nas disciplinas voltadas à pesquisa e ensino. Além de atuar nos estágios

\section{JÉSSICA SUZANA ALVES BARRAGAN}

Licenciada em Matemática pela Universidade Estadual de Maringá (2012), com participação em Projeto de Iniciação Científica sob orientação do Profo Dr. Fábio Matheus Amorin Natali sendo este desenvolvido na área de Análise Matemática intitulado: "Tópicos em Análise Harmônica". PósGraduada em Metodologia do Ensino de Matemática (2015). Foi aluna do mestrado em Matemática pela Universidade Estadual de Maringá (2015), tendo cursado as seguintes disciplinas: Grupos e Anéis e Seminários do PMA. Mestre em Bioestatística pela Universidade Estadual de Maringá (2019). Atualmente professora temporária na Universidade Estadual de Maringá com experiência na área de Análise Matemática, Probabilidade e Estatística, Farmacocinética e Educação Matemática, atuando principalmente nos seguintes temas: bioestatística, séries de fourier, mineração de dados, medicamentos procinéticos, probabilidade e estatística, formação de professores de Matemática da Educação.

\section{JÉSSICA TOMIKO ARAÚJO MITSUUCHI}

Mestranda no Programa de Pós-Graduação em Ciências e em Matemática (PPGECM), da Universidade Federal do Paraná, na Linha de Pesquisa em Formação de Professores que ensinam Matemática. Graduada em Pedagogia na Universidade Federal do Paraná (2018). Possui o Curso de Formação de Docentes. É participante do Grupo de Pesquisa em Ensino e Aprendizagem em Educação em Ciências e em Matemática (GPEACM). Foi bolsista de Iniciação à Docência do Programa Institucional de Bolsas de Iniciação à Docência (PIBID), atuando no Subprojeto Interdisciplinar Pedagogia e Matemática. Tem experiência na área de Educação, com ênfase em EnsinoAprendizagem em Matemática, no planejamento e execução de Projetos Temáticos voltados para o ensino de Matemática nos Anos Iniciais, bem como a elaboração de artigos acadêmicos e proposição de oficinas didáticas à professores e estudantes. 


\section{JORCÉLIA ERMÍNIA DA SILVA CARNEIRO}

Possui Mestrado pelo Programa de Pós- Graduação em Ensino de Ciências e Matemática - UNEMAT, Especialista em Alfabetização e Letramento pela FCARP, Pedagogia pela Universidade do Estado de Mato Grosso - UNEMAT (2004). Professora Efetiva na rede Estadual de Araputanga - MT. É professora no Ensino Superior ministrando aulas na disciplina de Estágio Supervisionado na Faculdade FQM na cidade de São José dos Quatro Marcos - MT.

\section{JOSÉ DAMIÃO SOUZA DE OLIVEIRA}

Possui graduação em matemática-licenciatura plena pela Universidade Federal do Rio Grande do Norte (2012). Tem mestrado em Ensino de Ciências Naturais e Matemática pela Universidade Federal do Rio Grande do Norte (2014) atualmente é professor efetivo da rede estadual do ensino básico do Rio Grande do Norte atundo como técnico na Subcoodenadoria do Ensino fundamental e Professor do Instituto de Educação Superior Presidente Kennedy. Tem experiência na área de Educação, com ênfase em Ensino de Matemática, atuando principalmente nos seguintes temas: História da Matemática, Tecnologia da Informação e Comunicação, Geometria do Compasso e Currículo.

\section{JOSÉ MESSILDO VIANA NUNES}

Graduado em Licenciatura Plena Em Matemática pela Universidade do Estado do Pará (UEPA); com Aperfeiçoamento em Informática Educativa (UEPA); Especialização em Educação Matemática (UEPA); Mestrado em Educação em Ciências e Matemáticas pela Universidade Federal do Pará (UFPA) e Doutorado em Educação Matemática pala Pontifícia Universidade Católica de São Paulo (PUC-SP). Professor da Universidade Federal do Pará, com experiência na área de Matemática, com ênfase em Matemática e Educação Matemática, atuando principalmente nos seguintes temas: Argumentação em Matemática, História da Matemática, Didática da Matemática e Formação de Professores.

\section{JOSENILDO GOMES DE OLIVEIRA SOUZA}

Especialista em Ensino da Matemática pela UVA, Licenciado em Matemática pela UFRN. Participou de eventos nacionais de Educação Matemática. É docente da SEEC do RN da e Formador e Redator do currículo do RN e docente da rede privada do RN. Foi formador e orientador de TCC em Educação a Distância EAD no IFRN. Tem experiência em ensino da Matemática há 16 anos.

\section{KÉDNA SYUIANNE QUINTAS MELO}

Bacharel em Ciências Contábeis pelo Instituto Esperança de Ensino Superior - IESPES, Graduanda em Licenciatura em Matemática e Física pela Universidade Federal do Oeste do Pará - Ufopa. Participação e coordenação de projetos aplicados em colégios públicos na cidade de Santarém - PA de 2016 até 2018 abordando a interdisciplinaridade entre a disciplina de Matemática e a Contabilidade, trabalhando assuntos voltados para a Educação Financeira e Fiscal; Atuou como voluntária no Núcleo de Apoio Contábil e Fiscal (NAF); Realizou trabalhos voluntários declarando Imposto de Renda de pessoas que se autodeclaravam como baixa renda; É pesquisadora na área das Ciências Contábeis (com ênfase nas atuais mudanças legislativas que vem ocorrendo no setor pessoal, fiscal e contábil), Matemática e Física (com enfase na área da educação, novas metodologias de ensino voltado para as disciplinas de Matemática e Física. Atualmente trabalha como Analista Contábil. 


\section{LAURO LOPES PEREIRA NETO}

Possui graduação em Psicologia pela Universidade Federal de Pernambuco (1992), Mestrado em Psicologia Cognitiva pela Universidade Federal de Pernambuco (1998) e graduação em Formação de Psicólogo pelo Centro de Estudos Superiores de Maceió (2007). Doutorando em Ciências da Educação pela Universidade do Minho, Portugal. Atualmente é Professor Assistente pelo Instituto Federal de Educação, Ciência e Tecnologia de Alagoas - IFAL/Campus Maceió. Tem experiência nas áreas de Educação, Psicologia Cognitiva e Formação de Professores, atuando principalmente nos seguintes temas: psicologia educacional, psicologia cognitiva, educação matemática e psicologia do desenvolvimento.

\section{LENILSON OLIVEIRA DO NASCIMENTO}

Licenciado em Matemática pelo Instituto Federal de Alagoas (2019). Estagiário na área de educação matemática na Escola Estadual de Cegos Cyro Accioly (2018). Atualmente lecionando matemática no Centro Pedagógico Paulo Freire, escola da rede privada.

\section{LENY RODRIGUES MARTINS TEIXEIRA}

Graduada em Pedagogia pela Universidade Estadual Paulista Júlio de Mesquita Filho (1968), mestre (1983) e doutora (1992) em Psicologia Escolar e do Desenvolvimento Humano pela Universidade de São Paulo.Pós-doutorado em Psicologia da Educação Matemática na Université Paris Descartes,ParisV,França. Professora assistente doutor na FCT Unesp de Presidente Prudente e na Universidade Católica Dom Bosco. Experiência de pesquisa na área de Psicologia Escolar e Formação de Professores.

\section{LEONILSON CALIXTO DE SOUZA}

Graduado pela Universidade do Estado de Mato Grosso, Faculdade de Matemática - Cáceres - Mato Grosso. Docente atuante na Escola Plena Deputado Bertoldo Freire.

\section{LIDIA SCHACTAI SILVANO}

Graduada em Licenciatura em Pedagogia pela Universidade Estadual de Ponta Grossa - UEPG (1995), Pós Graduada em Pedagogia Terapêutica pela Universidade Tuiuti do Paraná (1997); Pós Graduada em Educação Especial pela Universidade Estadual de Ponta Grossa - UEPG(2005); Pós Graduada em Gestão Escolar pelo Instituto Superior Tupy - Sociedade Educacional de Santa Catarina (2008). Atualmente é Diretora da Escola Raio de Sol - Apae de Carambeí.

\section{LIGIANE OLIVEIRA DOS SANTOS SOUZA}

Possui graduação em Matemática e Pedagogia e atualmente está presente na Escola Herculano Borges e Escola Ceja 15 de Outubro

\section{LUCIANA FIGUEIREDO LACANALLO ARRAIS}

Doutora em Educação pela Universidade Estadual de Maringá (2011), mestrado em Educação (UEM2005) e graduação em Pedagogia pela mesma universidade (1996). Atualmente é docente adjunta da Universidade Estadual de Maringá, no Departamento de Teoria e Prática da Educação, na área de Prática de Ensino. É membro do Grupo de Pesquisa e Ensino Trabalho Educativo e Escolarização (GENTEE/CNPq) e da Oficina Pedagógica de Matemática (OPM/UEM). Coordenadora do PIBID projeto Pedagogia Foco Matemática. Desenvolve pesquisas nos seguintes temas: aprendizagem, conhecimento matemático, jogos, educação e ensino de matemática. 


\section{LUCIANA VIEIRA ANDRADE}

Doutoranda em Educação Matemática pela UNESP, Mestra em Ensino de Ciências Naturais e Matemática e Licenciada em Matemática pela UFRN. Participou de eventos Nacionais e Internacionais de Educação Matemática. É docente da SEEC do RN e Formadora e Redatora de currículo. Foi professora substituta da UFRN, supervisora PIBID, preceptora da RP, tutora e orientadora de TCC da SEDIS-UFRN. Tem experiência em ensino de Matemática há 20 anos.

\section{LUIZ FERNANDO CARVALHO}

Graduado em Licenciatura em Matemática e Mestre em Educação pela Universidade Estadual Paulista Júlio de Mesquita Filho (FCT/UNESP de Presidente Prudente). Foi aluno bolsista do Programa Institucional de Bolsa de Iniciação à Docência (PIBID/CAPES) do curso de Licenciatura em Matemática da FCT/UNESP no período de 2012 a 2015 e membro do Grupos de Pesquisa "Ensino e Aprendizagem como Objeto da Formação de Professores", da Unesp/Campus de Presidente Prudente. Atualmente é Professor da Educação Básica na Rede Municipal de Ensino de Ribeirão Preto/SP.

\section{LURIA THAMIRES BRITO DA COSTA}

Cursando Graduação Licenciatura em MATEMÁTICA no(a) UNIVERSIDADE FEDERAL DO TOCANTINS. 2019 Evento: Encontro Nacional de Educação Matematica. Natureza: ENCONTRO. Município: Cuiabá; UF: MT. Participou como: Palestrante; Título: A TRILHA DOS NÚMEROS: EXPLORANDO PISTAS E ENCONTRANDO MÚLTIPLOS. 2019 Evento: Semana Academica da Matematica. Natureza: ENCONTRO. Município: Araguaína; UF: TO. Participou como: Palestrante; Título: Matemágica na prática. 2018 Evento: Semana Academica da Matematica. Natureza: EXPOSIÇÃO. Município: Araguaína; UF: TO. Participou como: Palestrante; Título: TRILHA DOS MÚLTIPLOS.

\section{LUTECIA MARTINS DA SILVA}

Possui graduação em Pedagogia atualmente se encontra na função de vigilante na Escola Ceja 15 de Outubro.

\section{MARCELA MADANES CHAVIER}

Graduada pela Universidade do Estado de Mato Grosso, Faculdade de Matemática - Cáceres - Mato Grosso. Docente atuante na Escola Plena Deputado Bertoldo Freire.

\section{MARCUS VINÍCIUS PEREIRA}

Licenciado em Matemática, especialista em Metodologia de Ensino de Matemática e Mestre em Matemática pela Universidade de Brasília (UnB). Integra o Grupo de Investigação no Ensino da Matemática (GIEM) vinculado ao departamento de Matemática da Universidade de Brasília - UnB. Professor do Atendimento Educacional Especializado (AEE) em Altas Habilidades/Superdotação da Secretaria de Estado de Educação do Distrito Federal.

\section{MARIA CECÍLIA FONÇATTI}

Doutoranda em educação pelo Programa de Pós-graduação em Educação da Universidade Estadual Paulista Júlio de Mesquita Filho (FCT/UNESP). Graduada em Licenciatura em Matemática e Mestra em Matemática Aplicada e Computacional pela FCT/UNESP. Tem experiência na área de métodos de aproximação de equações diferenciais parciais, polinômios que satisfazem uma relação de recorrência de três termos e formação de professores de Matemática. Atualmente é professora bolsista do Departamento de Matemática e Computação da FCT/UNESP. 


\section{MARIA RAQUEL MIOTTO MORELATTI}

Doutora em Educação pela PUC/SP (2001) e Mestre em Matemática pela UFSCar/São Carlos (1992). Professora do Departamento de Matemática e Computação (DMC), coordenadora do Programa de Pós-Graduação em Educação (PPGE) da FCT/ UNESP/ Campus de Presidente Prudente e coordenadora do Grupo de Pesquisa Ensino e Aprendizagem como Objeto da Formação de Professores - GPEA. Foi coordenadora da Licenciatura em Matemática, chefe do Departamento de Matemática e Computação, Coordenadora de Gestão de Processos Educacionais do PIBID/UNESP e Coordenadora do Projeto Licenciatura em Matemática em Rede: UNESP/UFAM e Universidade do Minho, do Programa Licenciaturas Internacionais/PLI Portugal/CAPES. Atua no PPGE da FCT/UNESP, na linha de pesquisa Processos Formativos, Ensino e Aprendizagem, orientando trabalhos na temática ensino e aprendizagem de Matemática, Formação de Professores e Novas Tecnologias Educacionais.

\section{MARILUCE APARECIDA DE LIMA}

Possui graduação em Pedagogia e atualmente se encontra lotada na Creche Menino Jesus

\section{MARIO TANAKA FILHO}

Doutor pelo Instituto Alberto Luiz Coimbra de Pós-Graduação e Pesquisa em Engenharia CPPE/UFRJ (2011), Mestre em Matemática pela Universidade Federal do Rio de Janeiro (2004), Licenciado em Matemática pela Universidade Federal do Pará (2000). É professor Associado I na Universidade Federal do Oeste do Pará - UFOPA. Professor permanente do curso de Mestrado Profissional em Matemática em Rede Nacional - PROFMAT na UFOPA desde 2011. Professor permanente do curso de Mestrado em Ciências da Sociedade e membro do Comitê Editorial da Revista Ciências da Sociedade do Programa de Pós Graduação - ICS/UFOPA. Coordenou o curso de Licenciatura Integrada em Matemática e Física do PARFOR/UFOPA (2012 - 2014). Coordenador Regional das Olimpíadas Brasileiras de Matemática das Escolas Públicas - OBMEP desde 2013. Coordenador do Laboratório do programa de Ciências Exatas - LPCEX. Tem experiência na área de Matemática: C*Algebras e Matemática Aplicada: Otimização Não-Linear, Nonsmooth Optimization. Fundador do Observatório de Políticas Públicas no Ensino de Matemática - OPPEM, desenvolve pesquisas relacionadas a Educação Estatística e Métodos Quantitativos em Ciências Sociais na Região Oeste do Pará.

\section{MARLENE SILVA RODRIGUES}

Curso de magistério em 1986, possui graduação em Pedagogia pelo IVE- Instituto Várzea-grandense de Educação (2002). Especialização em Psicopedagogia pelo IVE- Instituto Várzea-grandense de Educação (2004). Atualmente é professora efetiva da Secretaria Estadual de Educação de Mato Grosso e da Secretaria Municipal de Educação, Cultura, Esporte e Lazer do município de Várzea Grande- Mato Grosso

\section{MARTA BURDA SCHASTAI}

Graduada em Licenciatura em Matemática pela Universidade Estadual de Ponta Grossa - UEPG (1995), mestre em Ensino de Ciência e Tecnologia pela Universidade Tecnológica Federal do Paraná - UTFPR (2012), doutora em Educação Matemática pela Universidade Estadual de Londrina - UEL (2017)). Participa do Grupo de Estudo e Pesquisa em Educação Matemática e Avaliação - GEPEMA. Atualmente professora da Educação Básica da Rede Municipal de Ensino de Ponta Grossa - PR e da Rede Estadual de Ensino do Estado do Paraná.

\section{MICHAEL ARAÚJO DE OLIVEIRA}

Mestrando em Ensino de Ciências e Matemática, UFAC, Licenciado em Matemática, UFAC, 2018. Professor da rede pública do Estado do Acre e do Amazonas. Pesquisador do Grupo de Estudo e Pesquisa em Formação do Professor de Matemática (FORPROMAT/UFAC). 


\section{MOISES DA SILVA SANTOS}

Cursando Graduação Licenciatura em MATEMÁTICA no(a) UNIVERSIDADE FEDERAL DO TOCANTINS. 08/2018 - 12/2019 Projeto/Projeto: Programa Institucional de Bolsa de Iniciação à Docência. Função: Professor da Educação Básica Instituição Financiadora: CAPES Público Alvo: Alunos de licenciatura Descrição Programa/Projeto: $12 \mathrm{~h}$ semanais. Participação em eventos: 2019 Evento: Encontro Nacional de Educação Matematica. Natureza: ENCONTRO. Município: Cuiabá; UF: MT. Participou como: Palestrante; Título: A TRILHA DOS NÚMEROS: EXPLORANDO PISTAS E ENCONTRANDO MÚLTIPLOS. 2019 Evento: Semana Academica da Matematica. Natureza: ENCONTRO. Município: Araguaína; UF: TO. Participou como: Palestrante; Título: Matemágica na prática. 2019 Evento: Semana Academica da Matematica. Natureza: EXPOSIÇÃO. Município: Araguaína; UF: TO. Participou como: Palestrante; Título: Geometria na Quadra Poliesportiva: uma Atividade Contextualizada. 2018 Evento: Semana Academica da Matematica. Natureza: EXPOSIÇÃO. Município: Araguaína; UF: TO. Participou como: Palestrante; Título: TRILHA DOS MÚLTIPLOS.

\section{MONICA FÜRKOTTER}

Doutora em Ciências (Matemática: Análise) pelo ICMC/USP São Carlos, Mestre em Matemática pelo ICMC/USP São Carlos e Licenciada em Matemática pela Unesp/Campus de Rio Claro. Docente aposentada da Unesp/Campus de Presidente Prudente. Atualmente é docente do Programa de Pósgraduação em Educação da Unoeste, membro dos Grupos de Pesquisa "Ensino e Aprendizagem como Objeto da Formação de Professores", da Unesp/Campus de Presidente Prudente e "Contexto Escolar e Processo de Ensino Aprendizagem: ações e interações" da Unoeste. Possui pesquisas na área de Educação, com ênfase em formação inicial e continuada de professores, ensino e aprendizagem de Matemática e Tecnologias Digitais de Informação e Comunicação na Educação.

\section{PAULO FIORAVANTE GIARETA}

Doutorado em Educação pela Universidade Federal do Paraná - UFPR (2013). Mestrado em Educação pela Fundação Universidade Regional de Blumenau - FURB (2008). Professor da Universidade Federal de Mato Grosso do Sul - UFMS (2014). Professor do Programa de Mestrado em Educação da Universidade Federal de Mato Grosso do Sul, Campus de Três Lagoas (PPGECPTL/UFMS). Coordenador do Curso de Pedagogia da UFMS/CPTL. Líder do GForP - Grupo de Estudos em Formação de Professores da UFMS/CPTL. Membro do Grupo de Pesquisa Laboratório de Ensino Aprendizagem - LEA (UFMS/CPTL); Coordenador do Projeto de Pesquisa Pedagogia Universitária para Formação de Pedagogos e a Qualidade da Educação Básica - UFMS/CPTL. Atua nas áreas de Filosofia da Educação, Gestão e Currículo e Politica de Formação de Professores.

\section{RENATA APARECIDA DE SOUZA}

Doutoranda pela Universidade Estadual Paulista "Júlio de Mesquita Filho" - UNESP. Possui Mestrado pelo Programa de Pós- Graduação em Ensino de Ciências e Matemática - UNEMAT, Pedagogia pela Universidade do Estado de Mato Grosso - UNEMAT (2005). Possui ATESTO para atuar como Tradutora/Intérprete de Língua Brasileira de Sinais (Libras). Professora Efetiva na rede Municipal e Estadual de Araputanga - MT. Atualmente exerce a função de Tradutora/Intérprete no Ensino Fundamental I. É professora no Ensino Superior ministrando aulas na disciplina de Língua Brasileira de Sinais - Libras, Educação Especial e Inclusão e Metodologia de Ensino para a Educação Especial na Faculdade Católica Rainha da Paz - FCARP. 


\section{ROBERTO BARCELOS SOUZA}

Licenciado em Matemática (UFG), Mestre em Educação em Ciências e Matemática pela Universidade Federal de Goiás (UFG) e Doutor em Educação Matemática pela (UNESP/RIO CLARO), sob orientação do Professor Ubiratan DAmbrósio. Professor do Curso de Licenciatura em Matemática da Universidade Estadual de Goiás (UEG) Campus de Quirinópolis. Professor do Programa de Pósgraduação Stricto Sensu em Ensino de Ciências - Campus Henrique Santillo e professor colaborador no Programa de Pós-graduação Stricto Sensu Educação em Ciências e Matemática UFG. Diretor Educacional na Universidade Estadual de Goiás - Campus Quirinópolis. Como Linha de Pesquisa: Programa Etnomatemática; Formação de Professores e processos de ensino e aprendizagem de Matemática.

\section{SALETE MARIA CHALUB BANDEIRA}

Doutora em Educação, Ciências e Matemática pela Universidade Federal de Mato Grosso (UFMT polo UEA - 2015) na linha de Formação de Professores, com tese "OLHAR SEM OS OLHOS: Cognição e aprendizagem em contextos de inclusão - estratégias e percalços na formação inicial de docentes de matemática". Desde o ano de 1989 é Docente da Universidade Federal do Acre e atua no Curso de Licenciatura em Matemática. No ano de 2016, iniciou a sua colaboração como pesquisadora e docente no Mestrado Profissional em Ensino de Ciências e Matemática (MPECIM/UFAC) atuando nas linhas de pesquisa "Ensino e Aprendizagem em Ciências e Matemática" e "Recursos e Tecnologias no Ensino de Ciências e Matemática", atualmente coordenadora do MPECIM.

\section{SANDRA REGINA D' ANTONIO VERRENGIA}

Professora do Departamento de Matemática da Universidade Estadual Maringá - UEM. Possui graduação em Matemática pela Universidade Estadual De Maringá (2002), especialização em Gestão Educacional pelo Instituto Paranaense de Educação (2007), Mestrado (2006) e Doutorado (2013) em Educação para a Ciência e o Ensino de Matemática pela Universidade Estadual de Maringá (2006). Atualmente leciona as disciplinas de Estágio Supervisionado I. II, III e IV e Teoria e Prática Pedagógica I, II, III e IV no Curso de Licenciatura em Matemática e as disciplinas de Metodologia do Ensino de Matemática para o Curso de Pedagogia presencial e Educação Matemática e as Operações Fundamentais no Curso de Pedagogia à distância. É membro do Laboratório de Ensino de Matemática onde desenvolve atividades de formação continuada, atendendo professores da Educação Infantil e do Ensino Fundamental I, II e Médio de Maringá e região. Vice-coordenadora do GEPEME - Grupo de Estudo e Pesquisa em Matemática Escolar. Vice-presidente do Fórum das Licenciaturas da UEM e atual Coordenadora da CAE - Coordenadoria de Apoio à Educação Básica/ UEM. Atuou como docente na Educação Infantil e no Ensino Fundamental I de 2001 a 2015 e no Ensino Fundamental II e Ensino Médio de 2005 a 2017. Participou do PNAIC - Programa Nacional de Alfabetização na Idade Certa dando formação aos professores.

\section{SINVAL DE OLIVEIRA}

Professor Adjunto da Universidade Federal do Tocantins - UFT, está vinculado ao Curso de Licenciatura em Matemática, Câmpus de Araguaína - TO. Tem interesse por áreas de pesquisa vinculadas a Formação de Professores, Educação Indígena e Etnomatemática. 


\section{TANIA TERESINHA BRUNS ZIMER}

Possui graduação em Licenciatura em Matemática pela Universidade Federal do Paraná (1994), mestrado em Educação pela Universidade Federal do Paraná (2002) e doutorado em Educação pela Universidade de São Paulo (2008). Atualmente é professora Associado III da Universidade Federal do Paraná, no Setor de Educação, Departamento de Teoria e Prática de Ensino (DTPEN) e do Programa de Pós Graduação em Educação em Ciências e em Matemática da UFPR (PPGECM/UFPR). É vice-coordenadora do PPGECM/UFPR. Coordena o Núcleo de Estudos e Pesquisas de Professores que ensinam Matemática (NEPPREM). É lider do Grupo de Pesquisa de Ensino e Aprendizagem em Ciências e em Matemática (GPEACM). Tem experiência na área de Educação, com ênfase em Formação de Professores que ensinam Matemática (inicial e continuada), atuando principalmente nos seguintes temas: ensino-aprendizagem da matemática, metodologias de ensino (resolução de problemas, atividades lúdicas e brinquedoteca, modelagem matemática, atividade investigativa, entre outras), aprendizagem da docência, estágio em docência, educação infantil e educação à distância.

\section{VALÉRIA DE CÁSSIA GASQUES MORTARI}

Possui graduação em Ciências Físicas e Biológica com Licenciatura Plena em Matemática e Química e graduação em Pedagogia pela UNIFEV - Universidade Federal de Votuporanga -SP . Atualmente professora efetiva do Município de Cuiabá -MT e professora aposentada pela Secretaria Municipal de Educação de Mato Grosso/SEDUC-MT.

\section{VANESSA CRISTINA RHEA}

Professora temporária da Universidade Estadual de Maringá (UEM), desde março de 2017. Professora no curso de Pedagogia à distância - EAD UEM, em 2018 e 2019. Doutoranda no Programa de Pós-Graduação em Ensino de Ciências e Educação Matemática na Universidade Estadual de Londrina (UEL). Mestra pelo Programa de Pós-graduação em Educação para a Ciência e a Matemática pela Universidade Estadual de Maringá - UEM em 2018. Pós-Graduada em Metodologia e Ensino da Matemática na Faculdade Eficaz, em 2016. Graduada em Licenciatura em Matemática pela UEM em 2012. Aluna especial no Mestrado de Matemática Pura na UEM em 2014 e 2015, tendo cursado as seguintes disciplinas: Análise no Rn, Grupos e Anéis, Topologia Geral e Geometria Diferencial.

\section{VANILDA CARVALHO MENDES}

Graduada em Licenciatura Plena em Matemática pela UNIVERSIDADE Federal de Mato Grosso. Especialização em Neuroeducação pela faculdade Evangélica Integradas Cantares de Salomão. . Atualmente encontra -se como Professora efetiva de matemática na rede Municipal de Educação de Cuiabá e efetiva como Professora de matemática no município de Várzea Grande.

\section{VIVIANE MENEZES DE SOUZA MACHADO}

Mestre em Ensino de Ciências e Matemática pela Universidade Federal do Acre - UFAC, no ano de 2019. Licenciada em Matemática, pela UFAC, em 2006. Professora numa escola de Educação Básica desde 2006 e atualmente membro do Grupo de Estudo e Pesquisa em Linguagens, Práticas Culturais em Ensino de Ciências e Matemática - GEPLIMAC/UFAC.

\section{WIRLA CASTRO DE SOUZA RAMOS}

Possui Graduação em Pedagogia pela Universidade Federal do Acre - UFAC, Especialização em Psicopedagogia pela Faculdade de Ciências e Letras Plínio Augusto do Amaral - SP e Mestrado Profissional em Ensino de Matemática pela Universidade Federal do Acre - UFAC. Professora de Educação Infantil e Ensino Fundamental I. Atualmente Coordenadora Pedagógica na Secretaria Municipal de Educação de Rio Branco - Acre. 


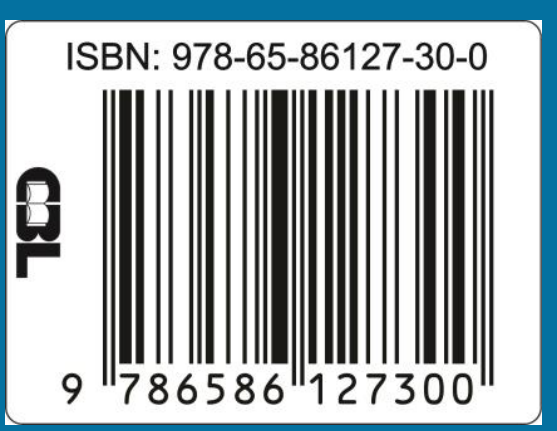

